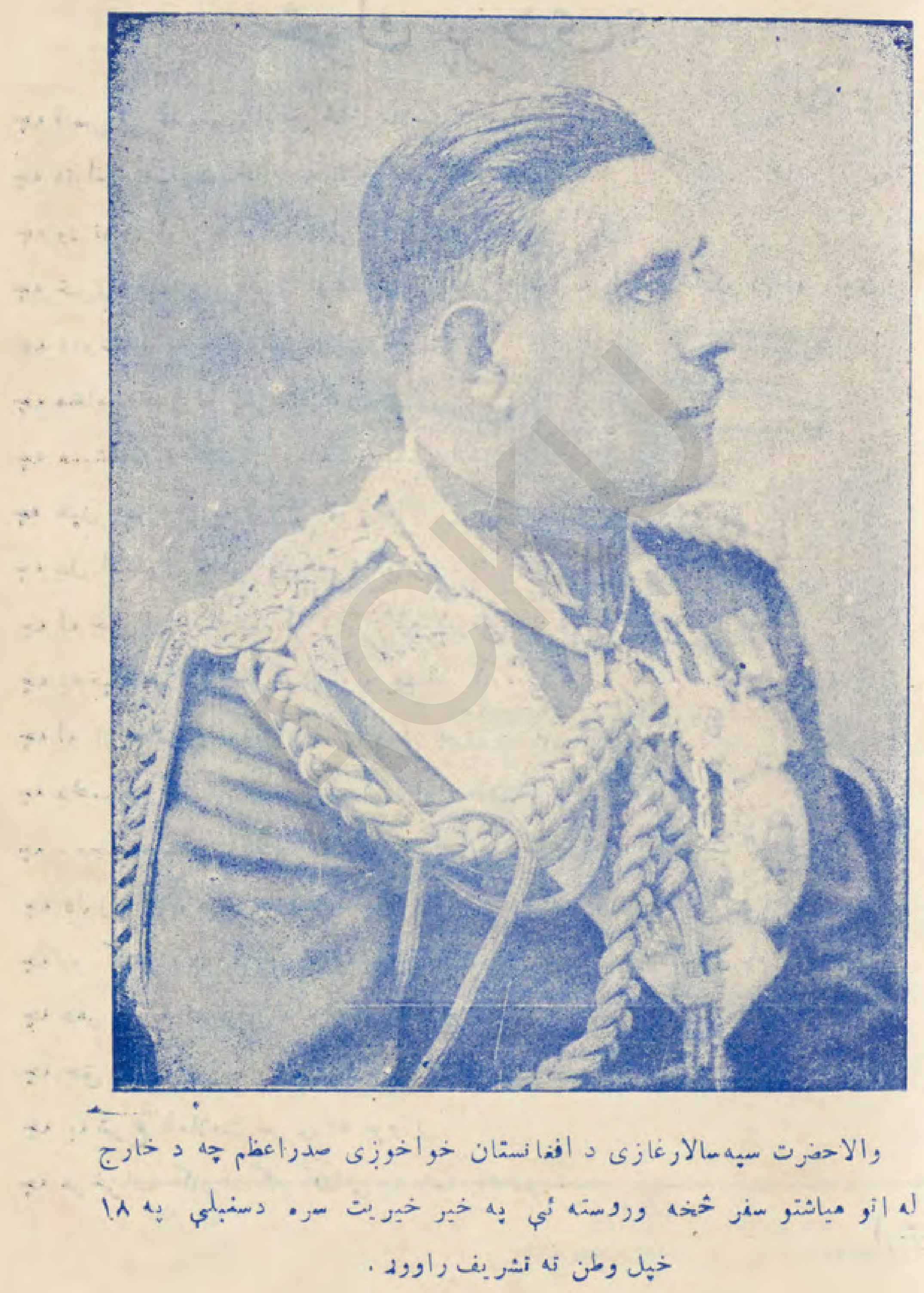




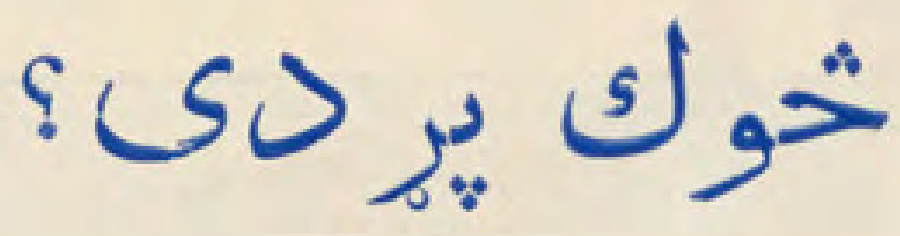

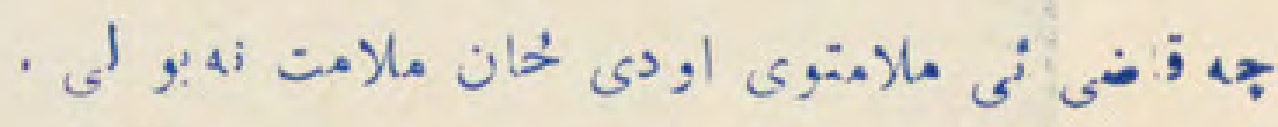

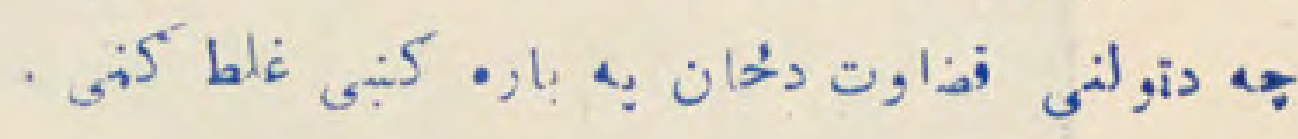

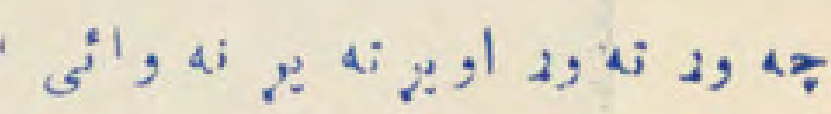

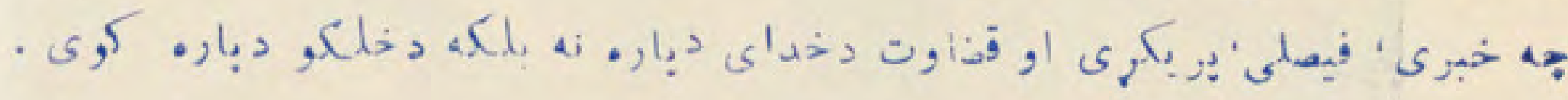

$$
\begin{aligned}
& \text {. } \\
& \text { ج }
\end{aligned}
$$

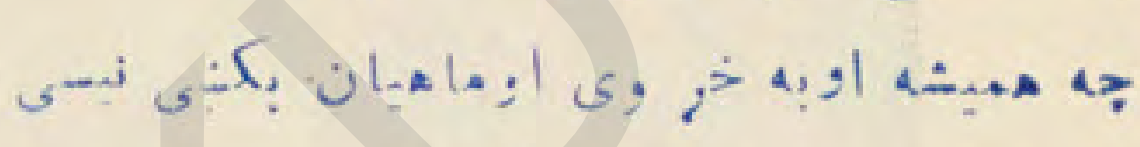

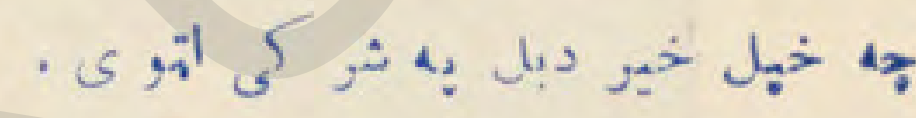

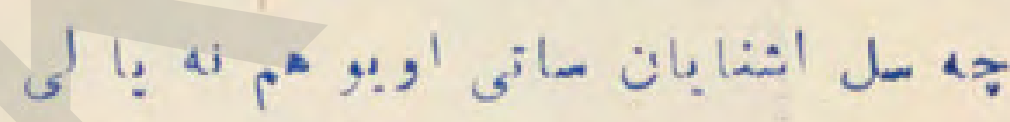

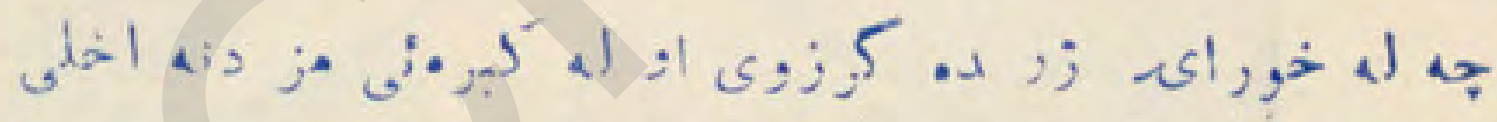

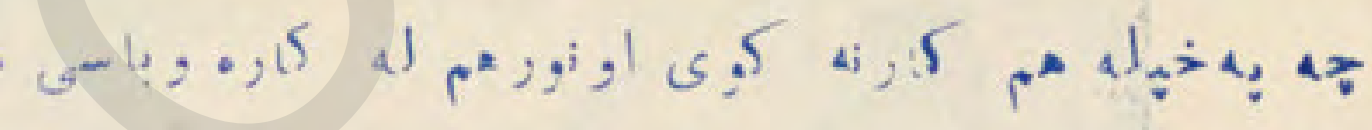

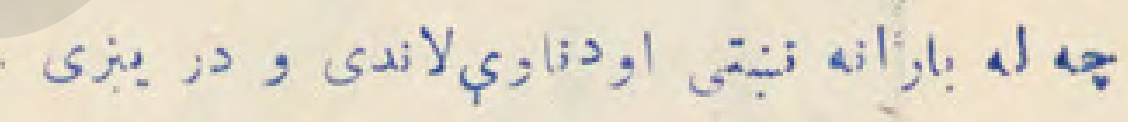$$
\text { ى }
$$

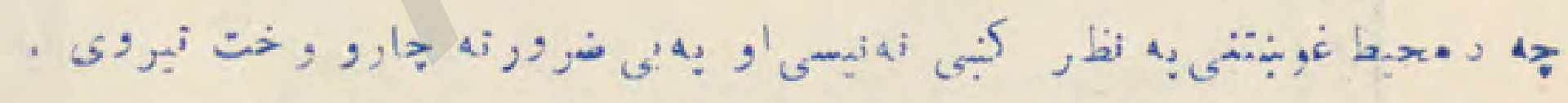

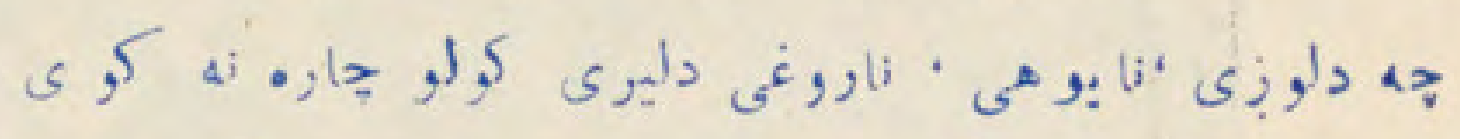$$
\text { جه , رو, كود, is }
$$

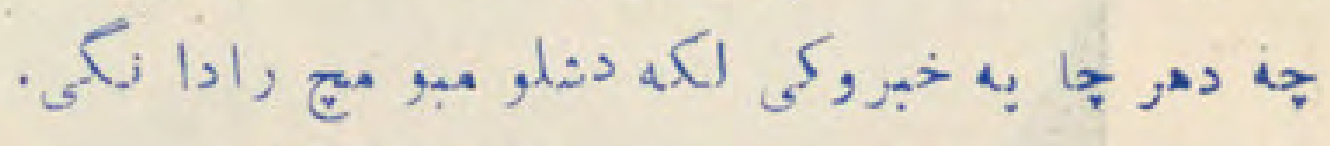

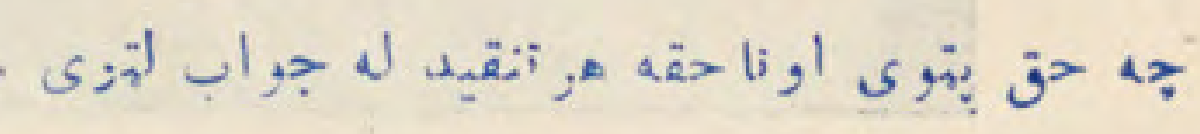

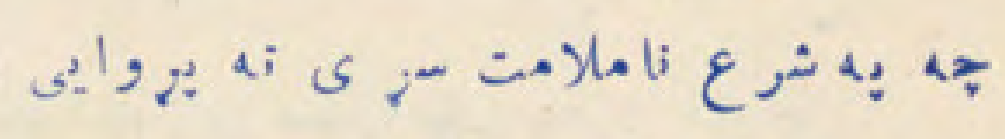

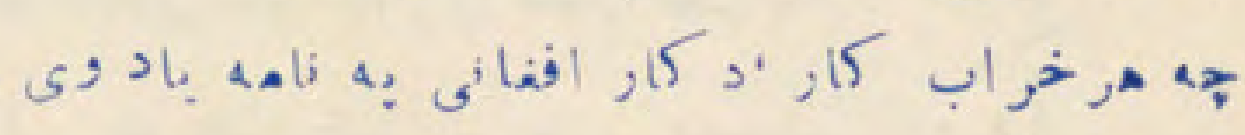

(رنيتن) 


$$
\begin{aligned}
& \text { rqV }
\end{aligned}
$$

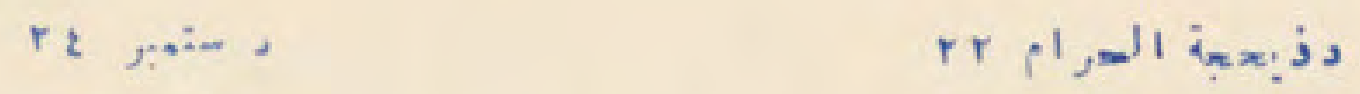

$$
\begin{aligned}
& 21901 \text { का } 180 \\
& \text { J إن, } \\
& 4 \cdot 5(1 \%) \\
& \text { i ip. } \\
& \text { دا) كال } \\
& \text { 0) بـ }
\end{aligned}
$$

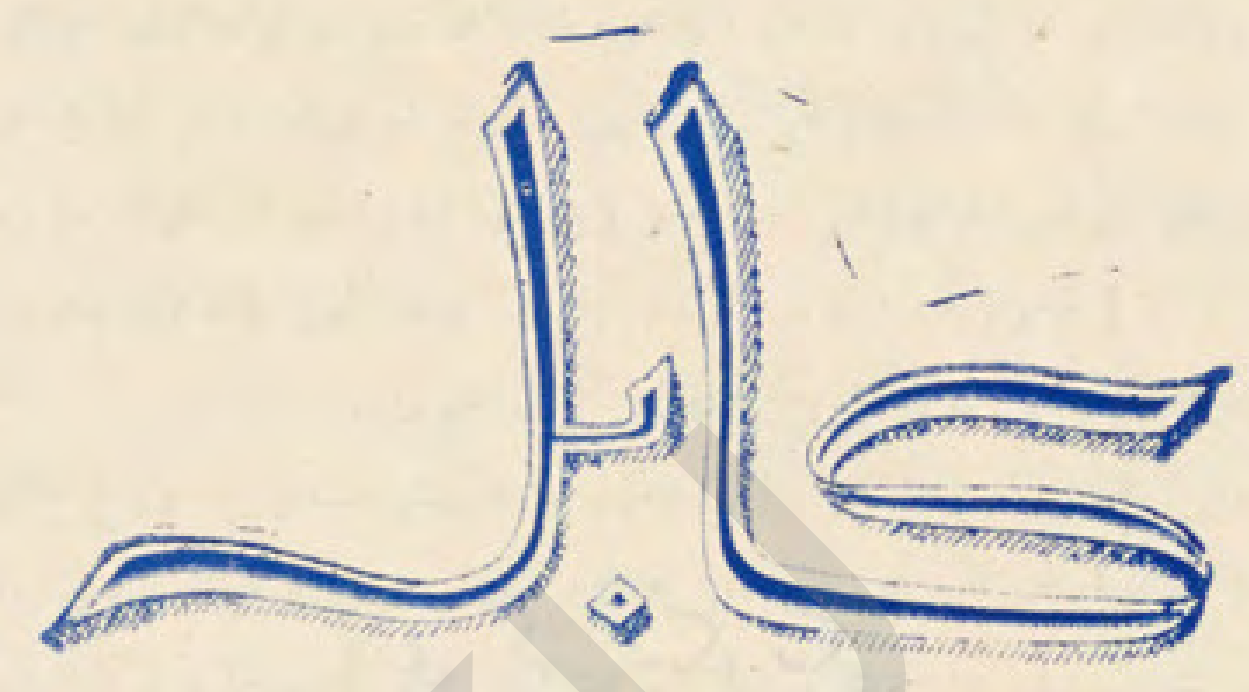

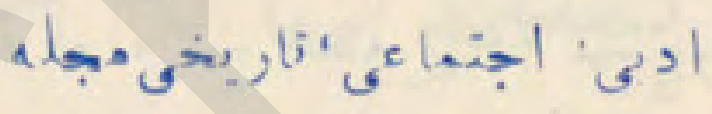

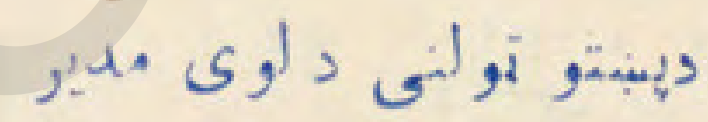

$$
\begin{aligned}
& \text { صايق الله رشتين } \\
& \text {; }
\end{aligned}
$$

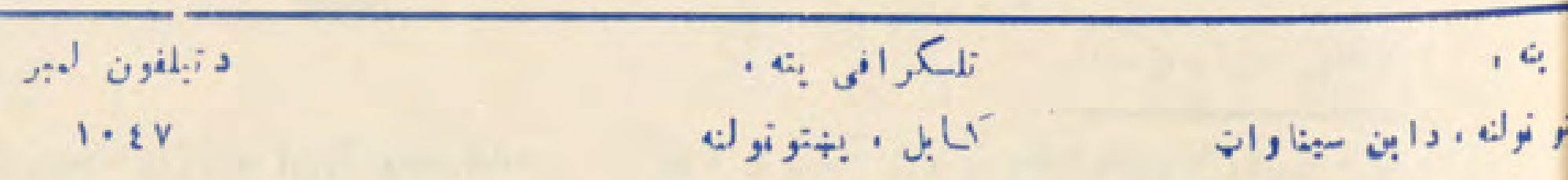


دי كنى ليكو, نكى

is.

Sig

SU

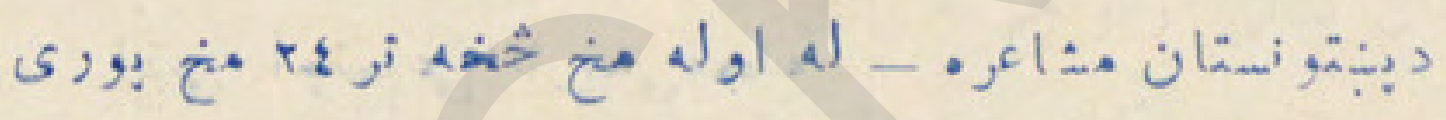

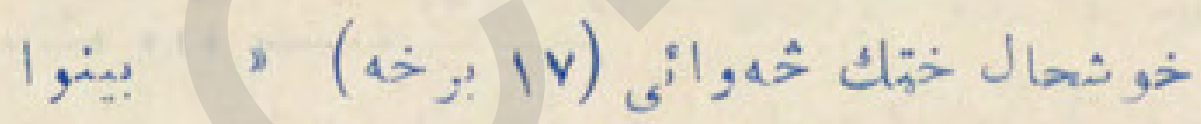

in, ) ( 


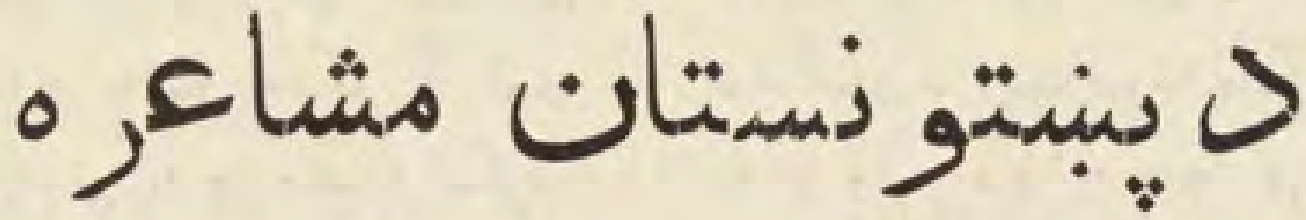

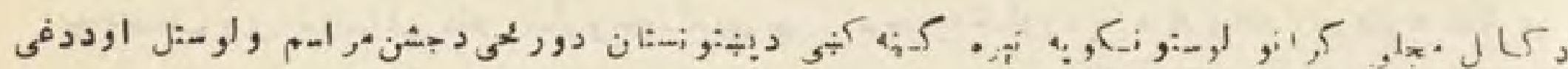

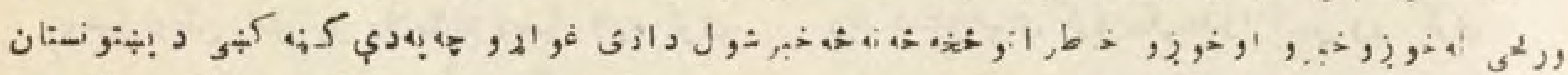

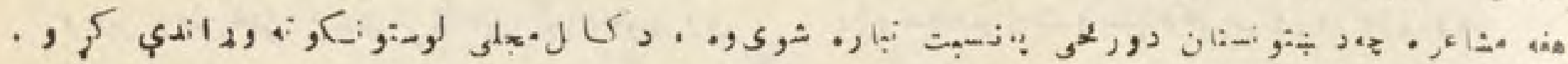

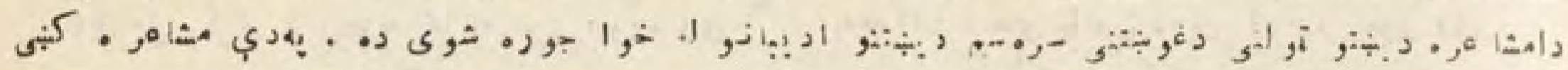

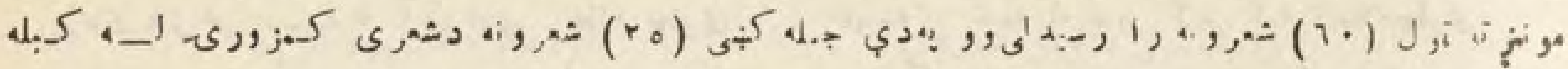

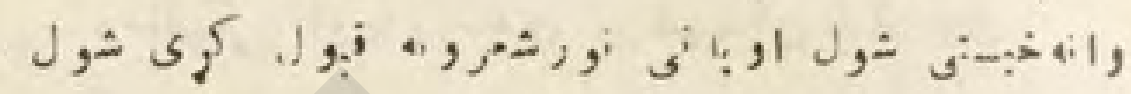

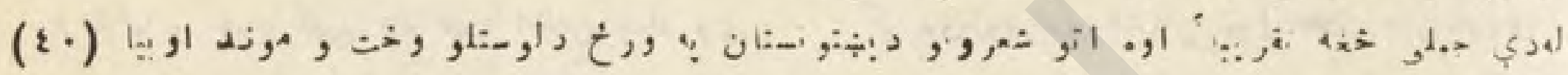

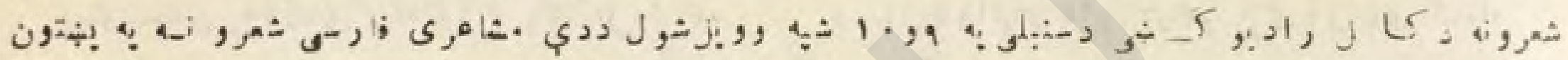

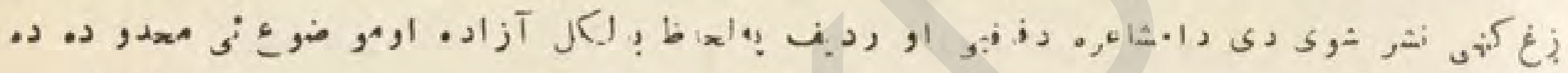

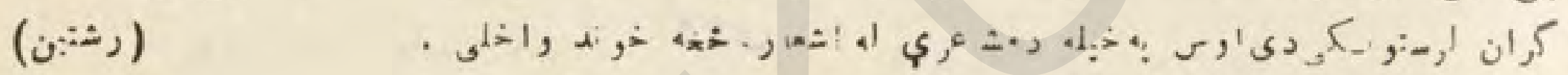

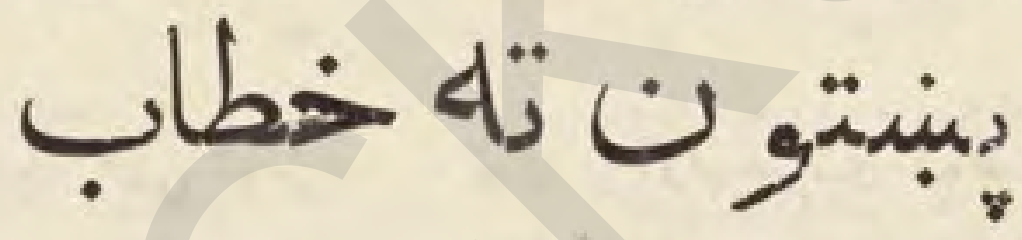

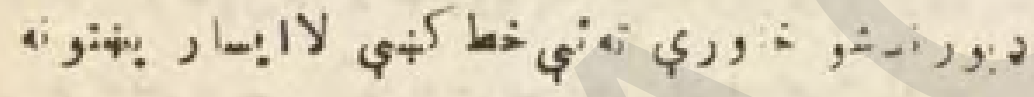

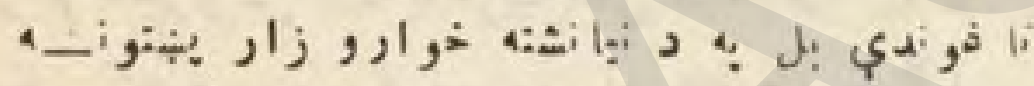

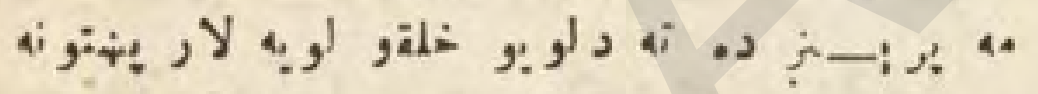
ه

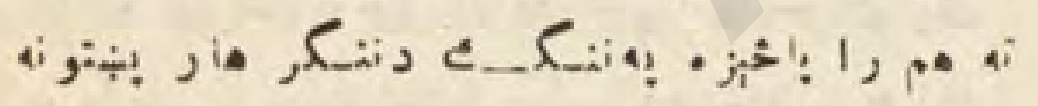

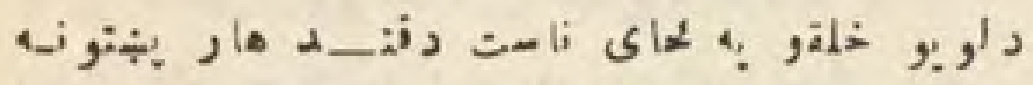
دهن

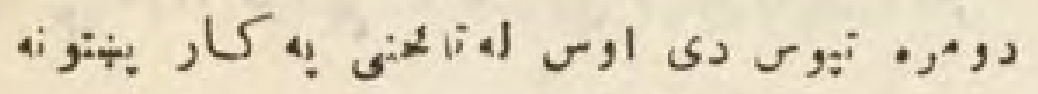

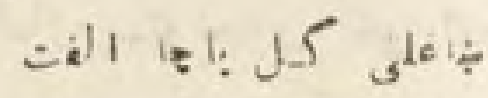

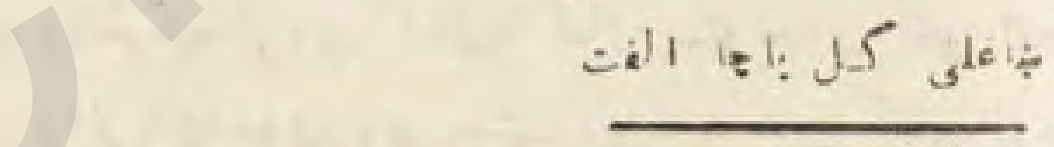

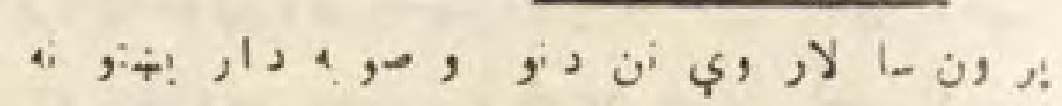

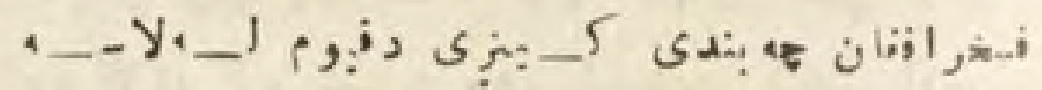

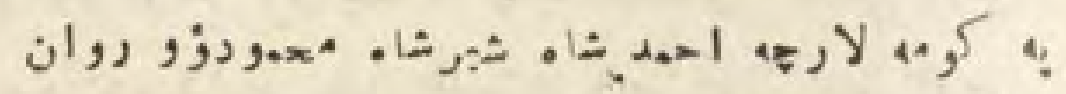

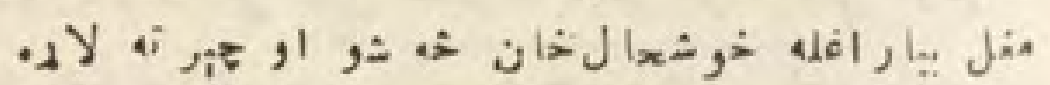
! در

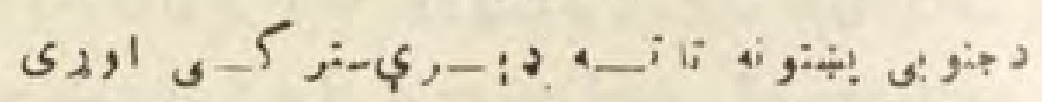

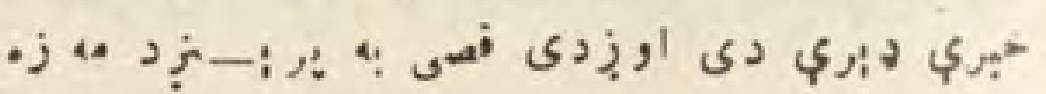

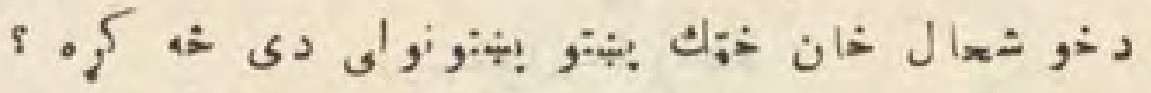
s.

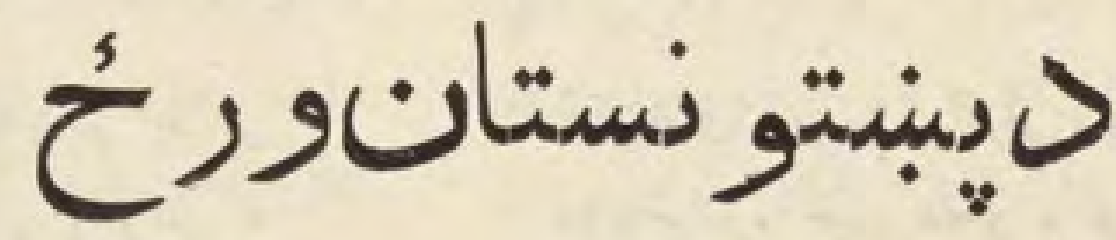

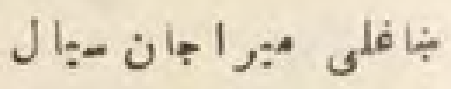

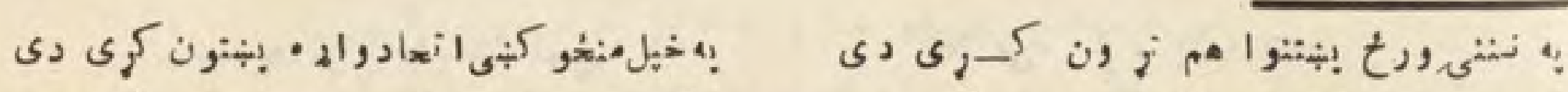

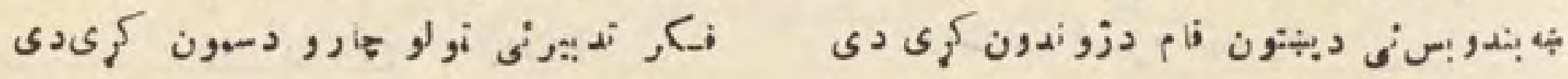

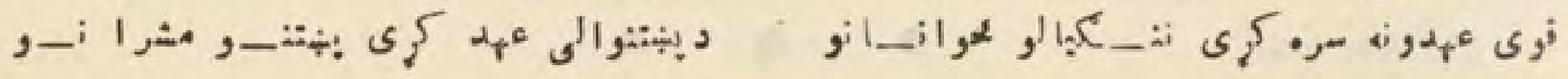


(r)

s) ج

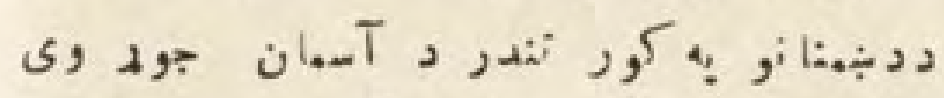

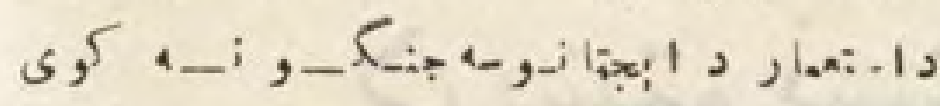
ى, ى

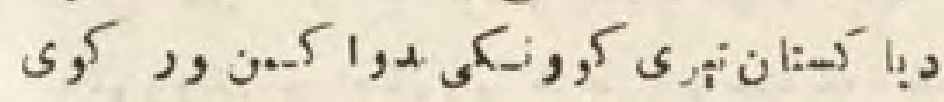

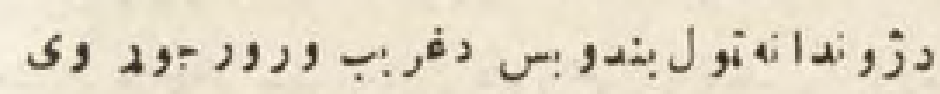
? خوبهن

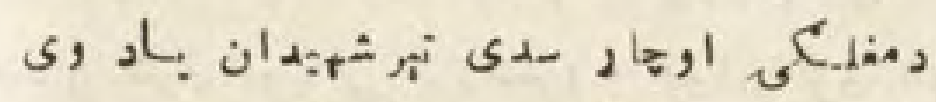

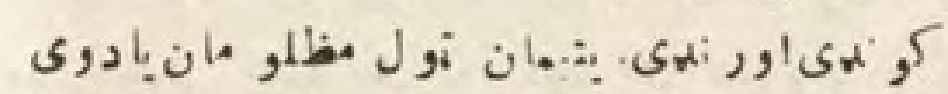

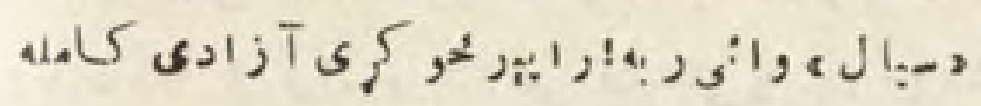

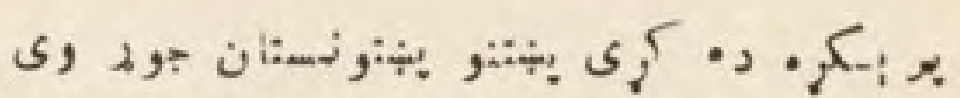

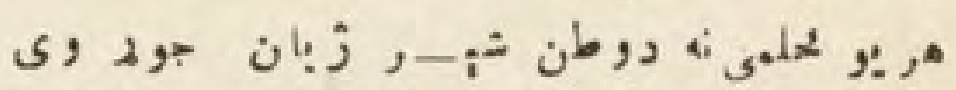

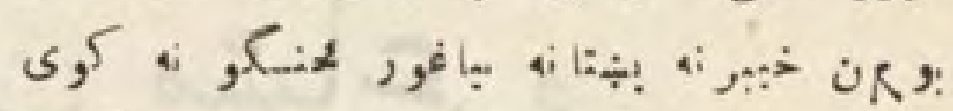

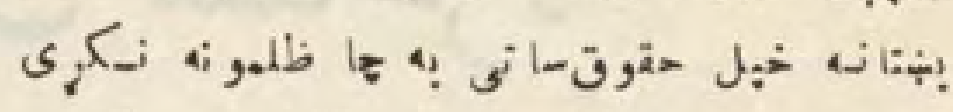

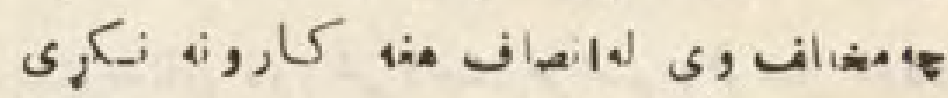

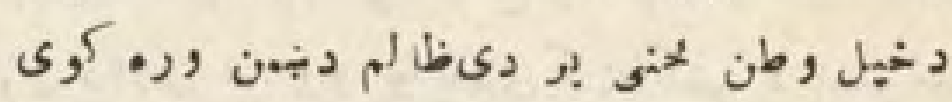

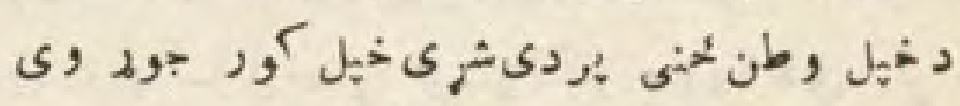

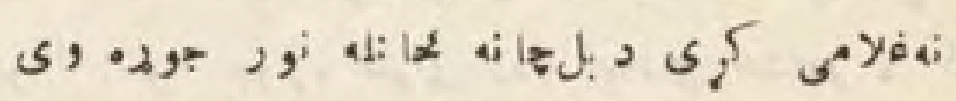

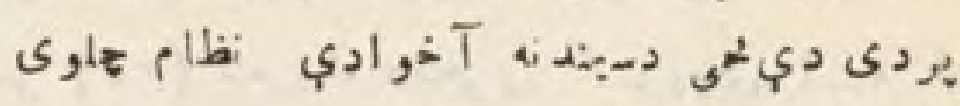

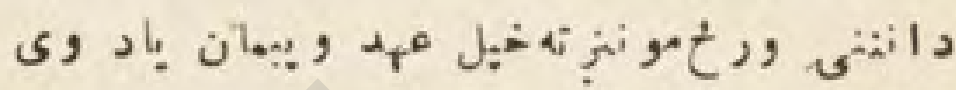

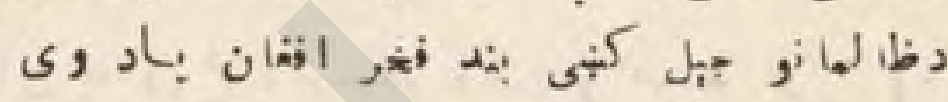

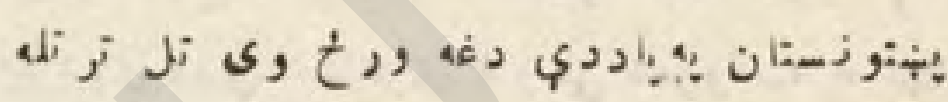

$$
\text { نان }
$$

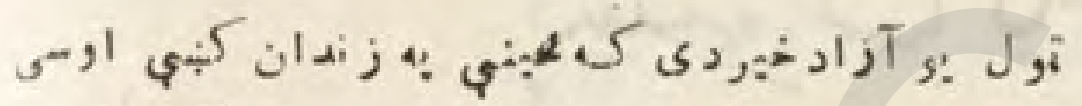

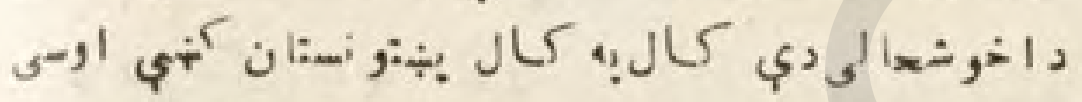

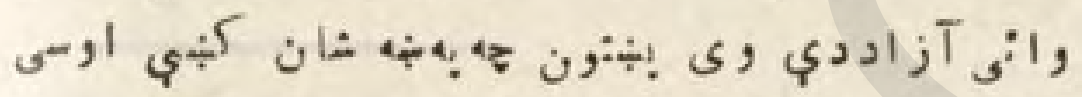

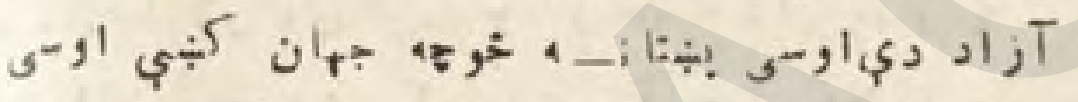

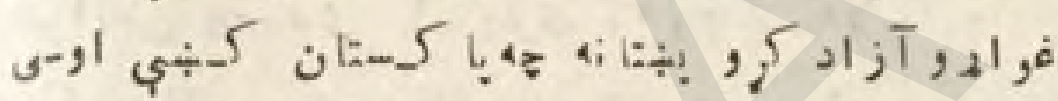
:

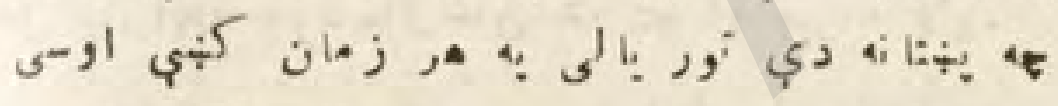

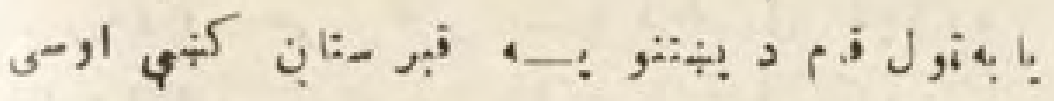

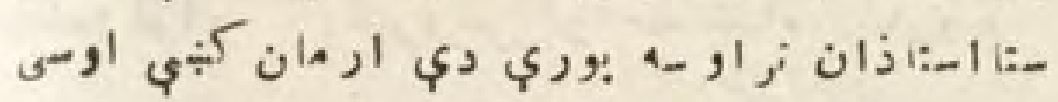

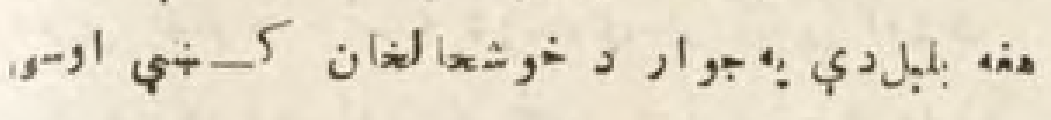

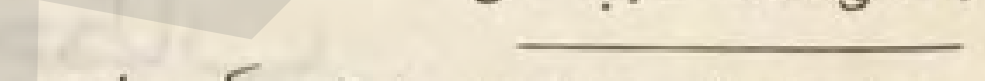

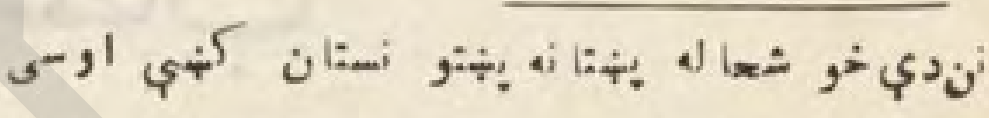

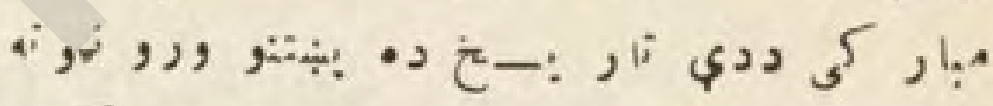

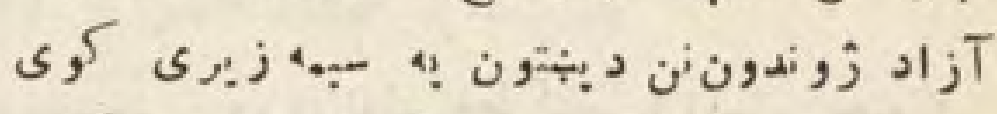

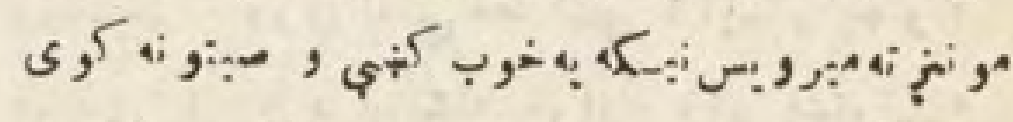

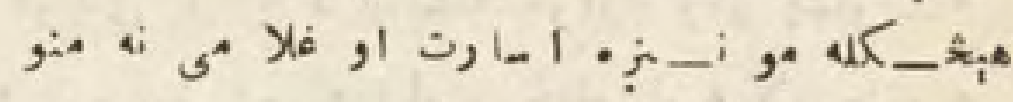

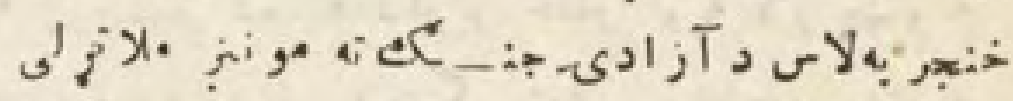

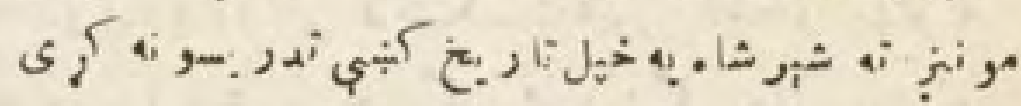

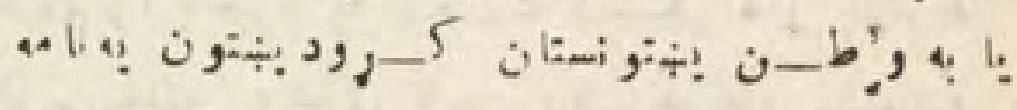

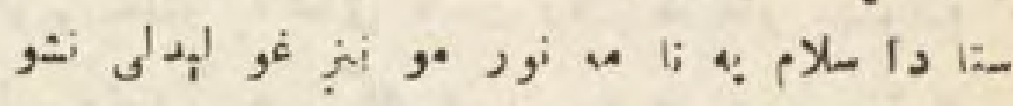

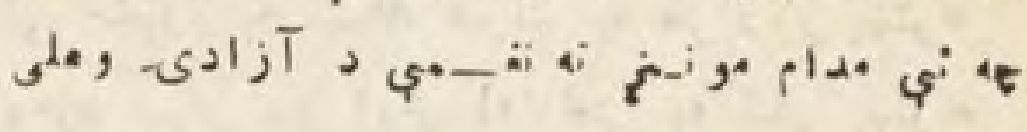

\section{ديبتون آزاده}

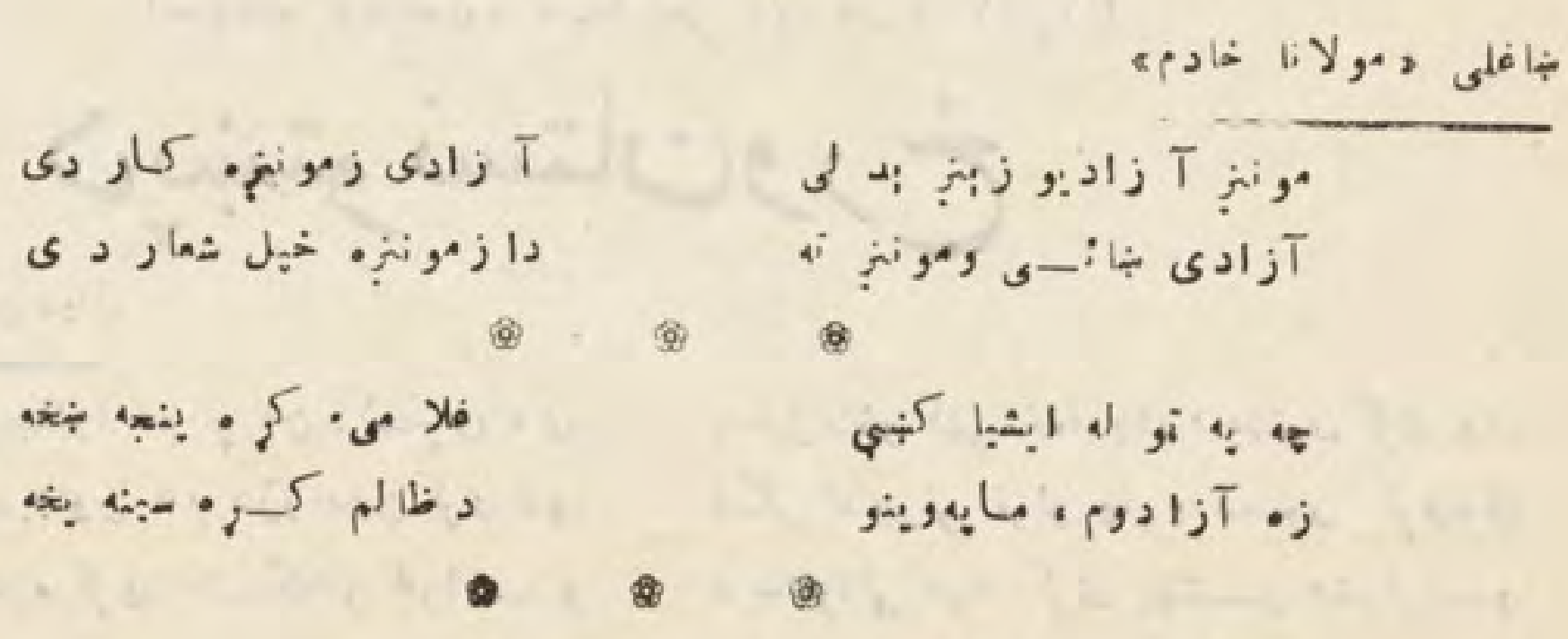


(r)

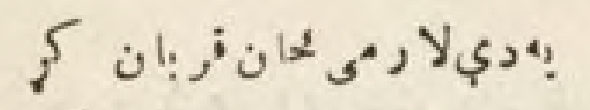

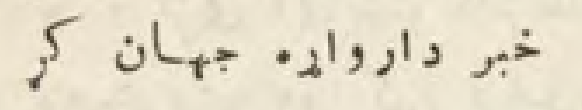

$$
\begin{aligned}
& \text { دون } \\
& \text { ى د }
\end{aligned}
$$

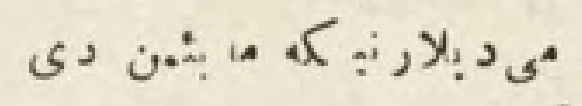

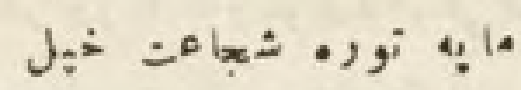

$$
\begin{aligned}
& \text { (2) (8) } \\
& \text {, }
\end{aligned}
$$

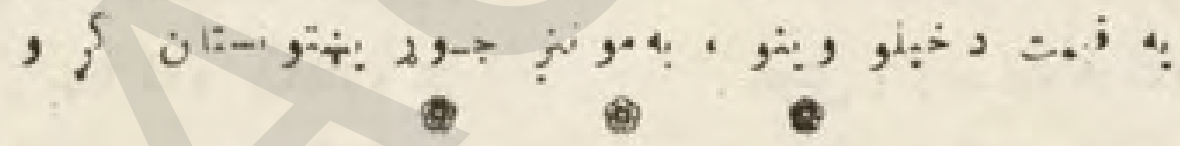

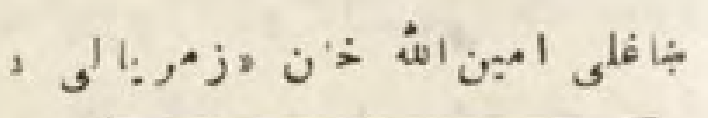

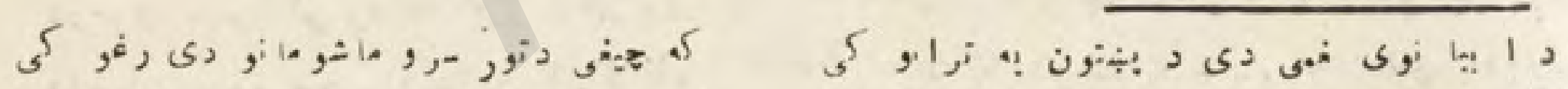

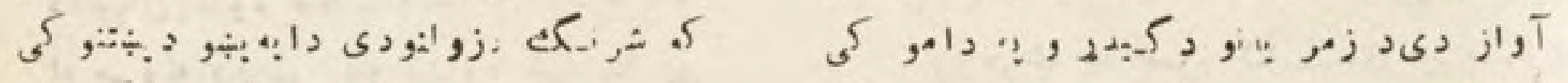

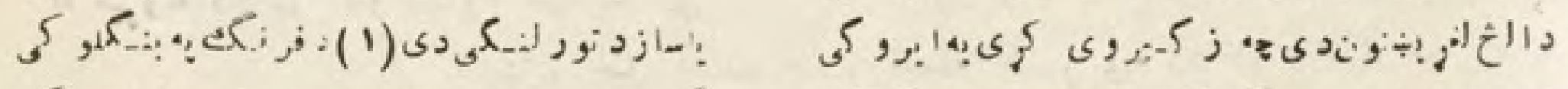

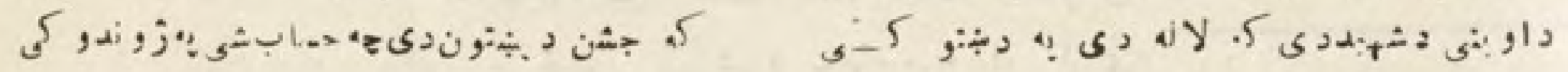
كى

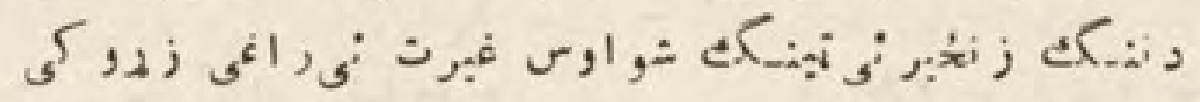

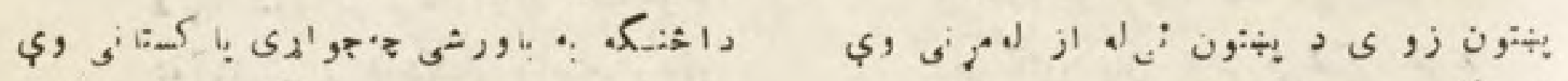

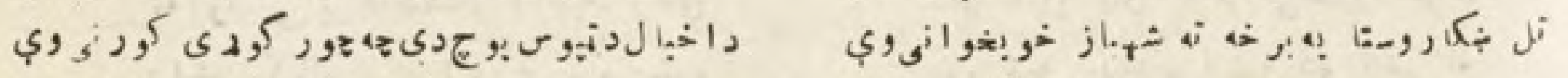

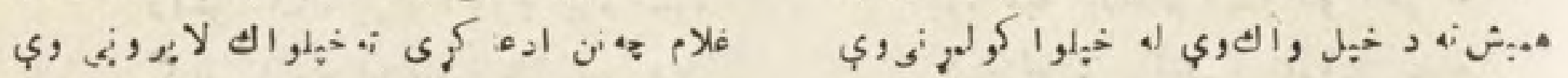

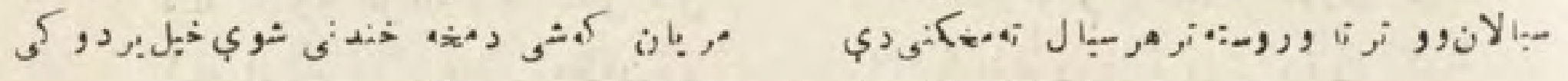

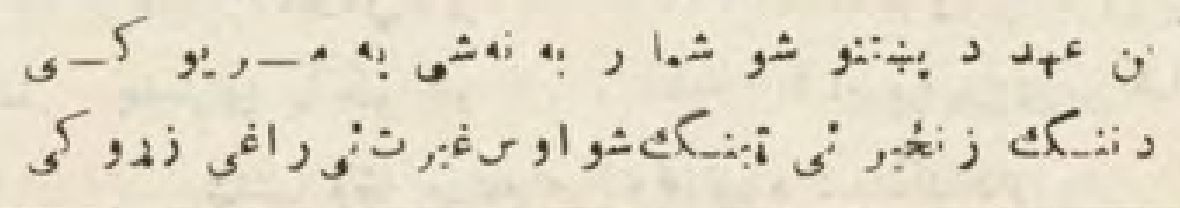


(

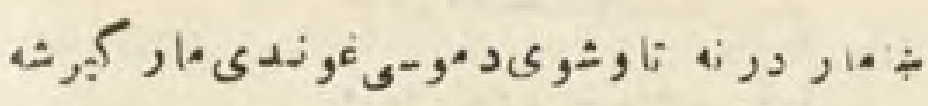

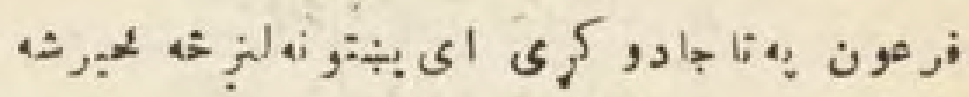

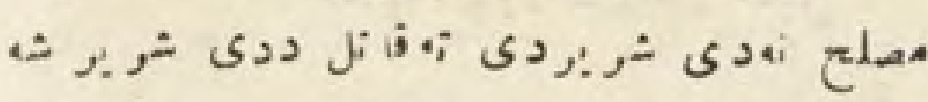

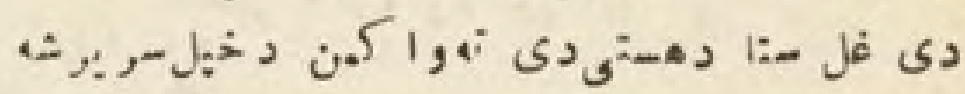

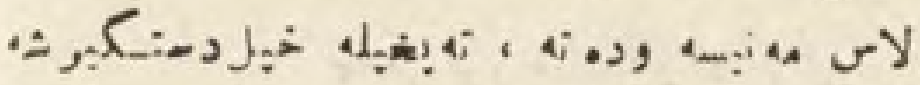

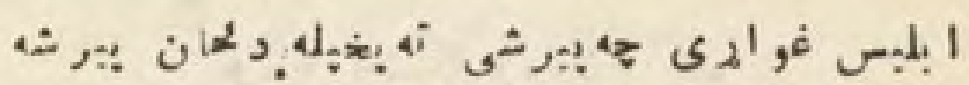

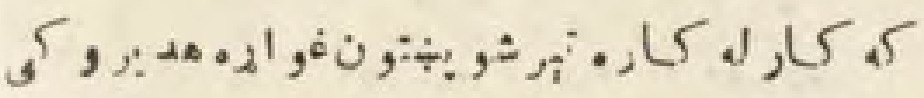

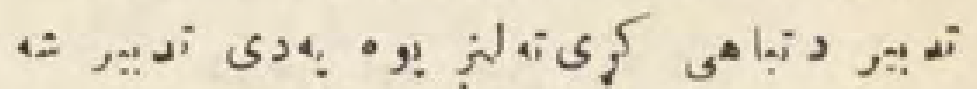

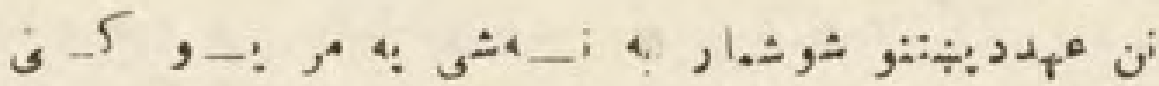

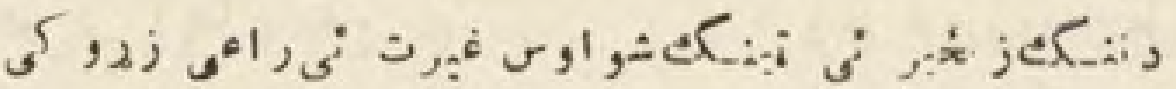

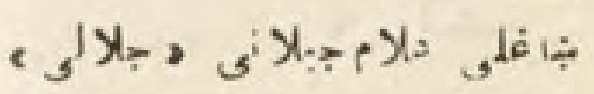

\section{ديخيتو نسمتان لموى اختر}

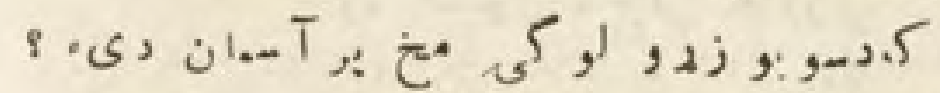

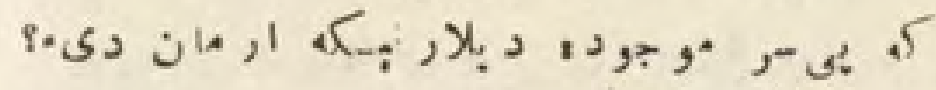

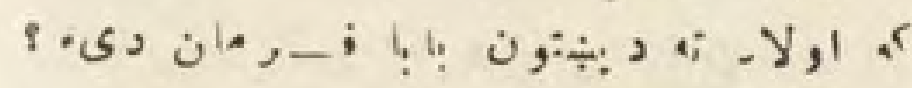

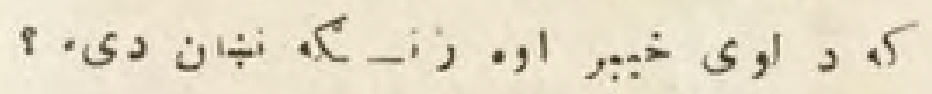

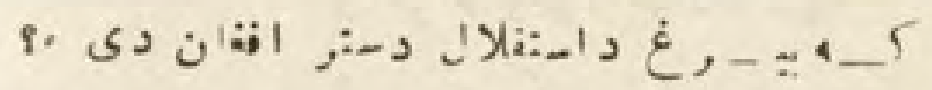

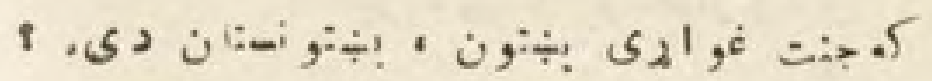

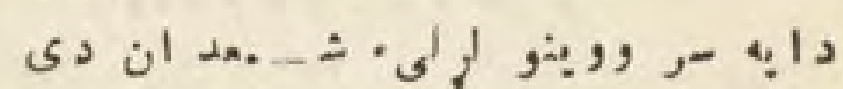
دش:

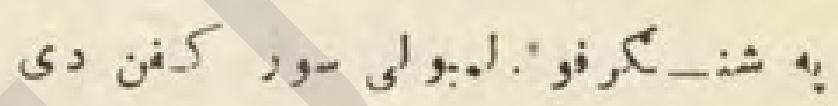
داد بو.د.دمش-به

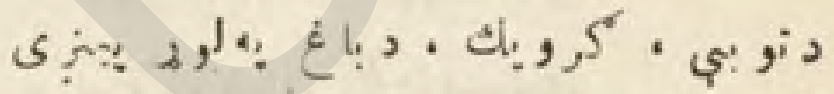

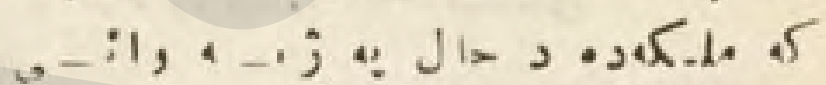

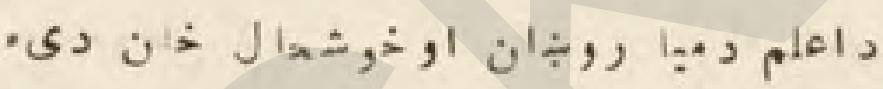

$$
\begin{aligned}
& \text { را }
\end{aligned}
$$

ى د,

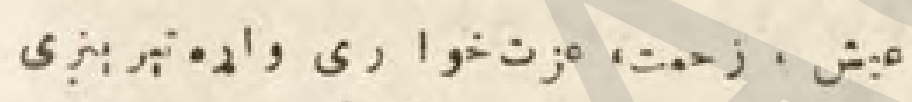

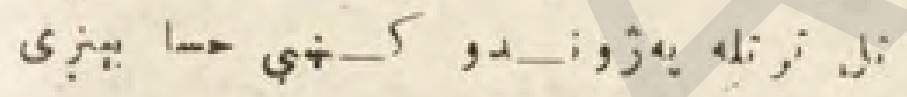

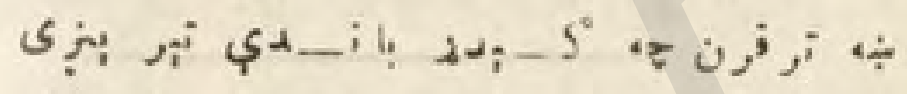

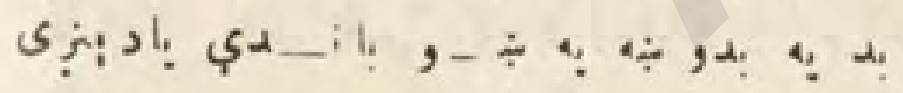
i وره

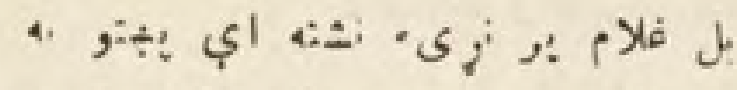

4, د, ,

:

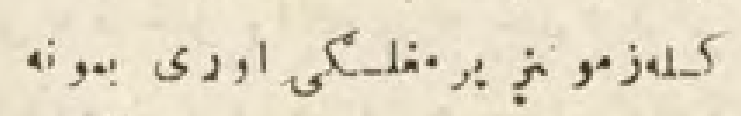

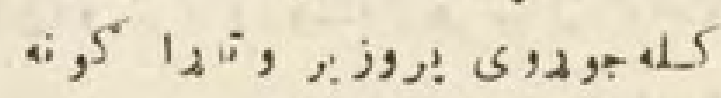

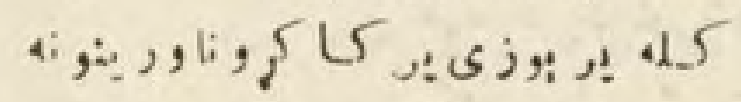

$$
\begin{aligned}
& \text { ن }
\end{aligned}
$$

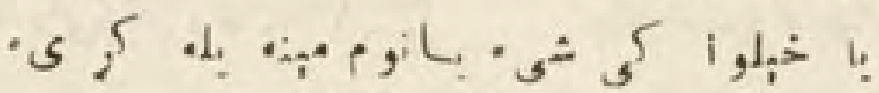

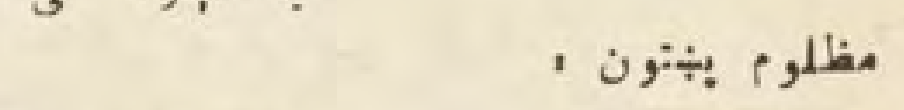

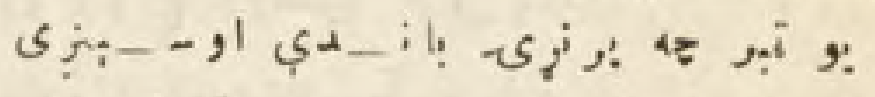

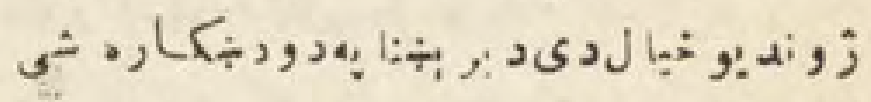
وزه

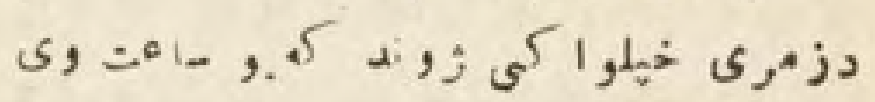
دا-بهان:-2

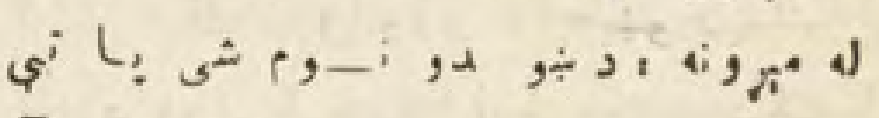

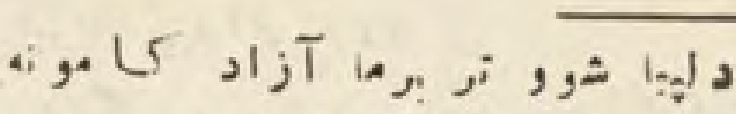

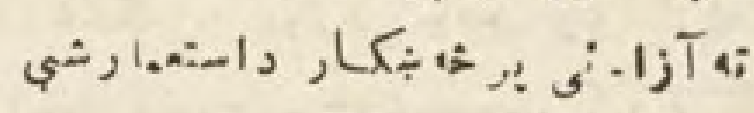

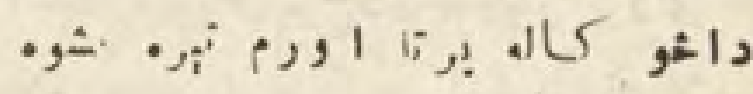

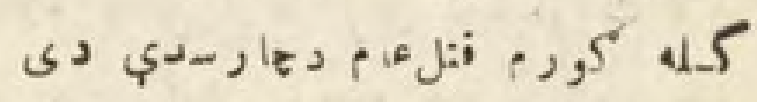

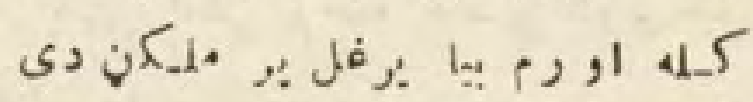

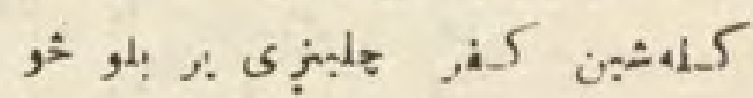

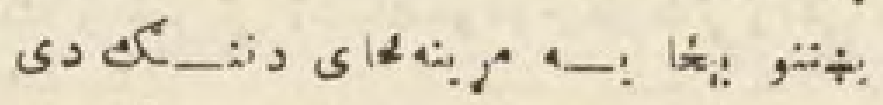
زهر, ك,ى 
$(\cdot)$

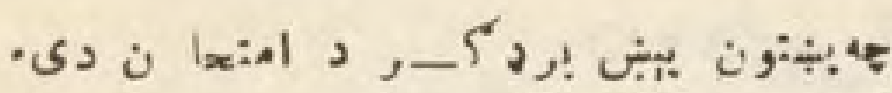

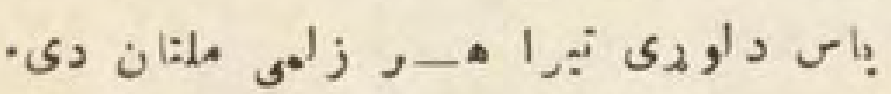

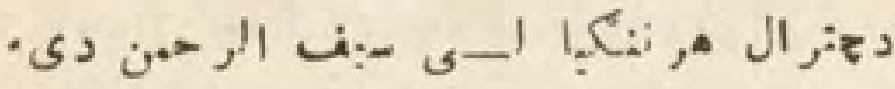

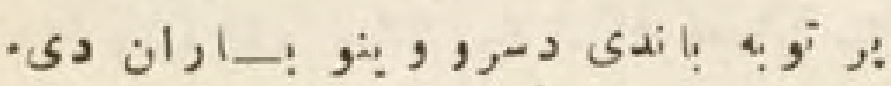

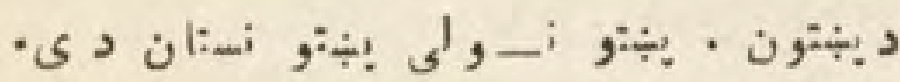

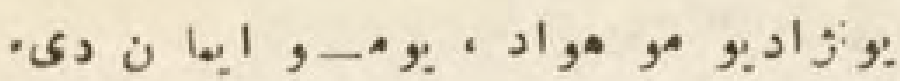

$\cdot\left(4 i_{2} \log \right) \cdot 40$

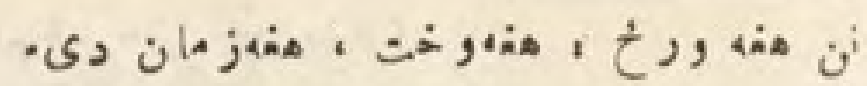

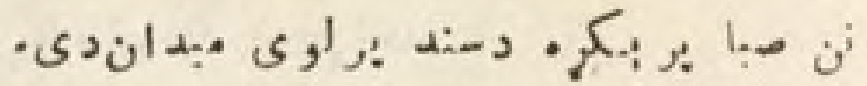

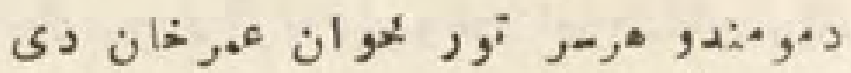

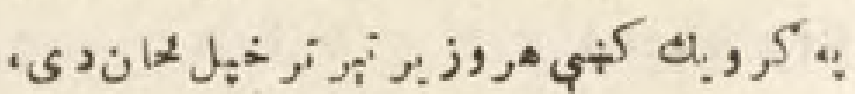

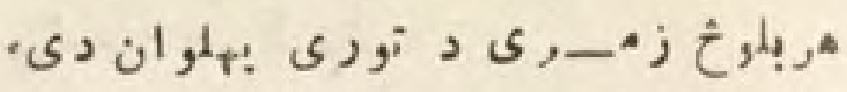

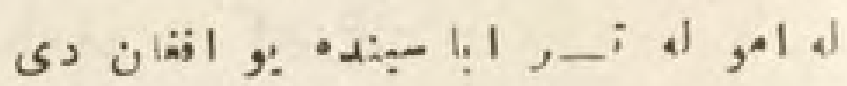

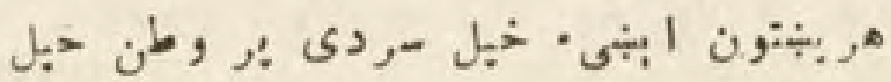

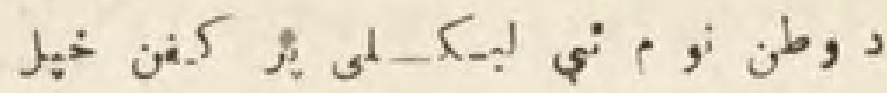

بخافلى درد

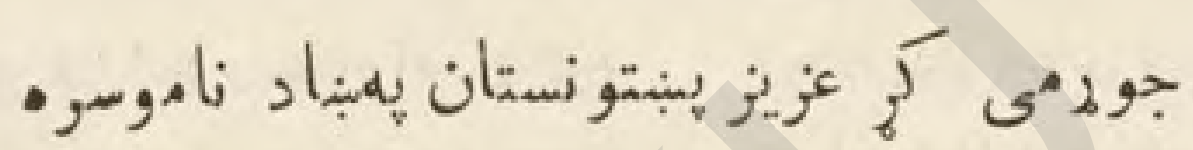

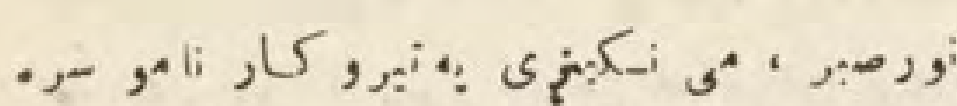

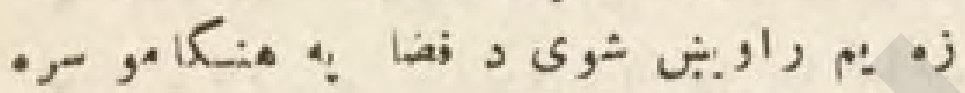

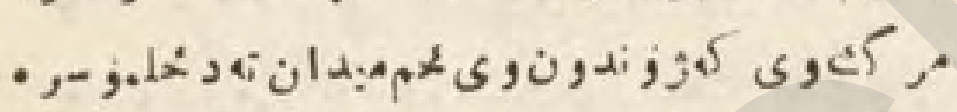

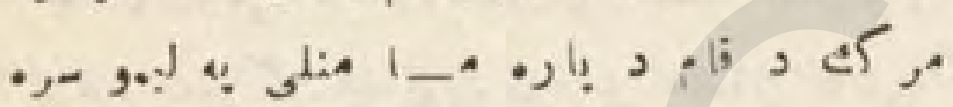

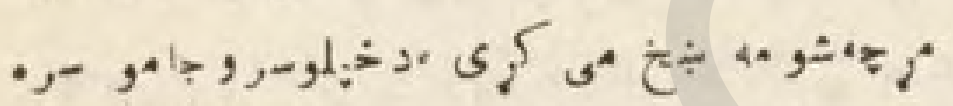

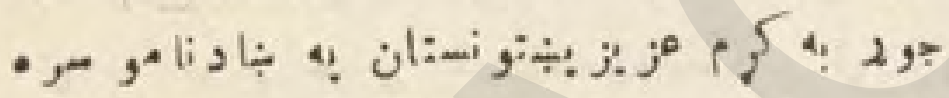

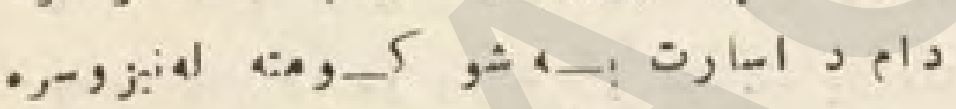

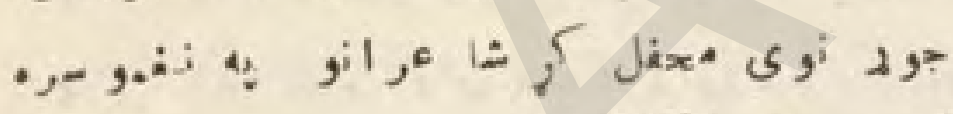

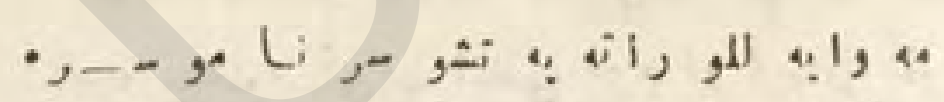
4.

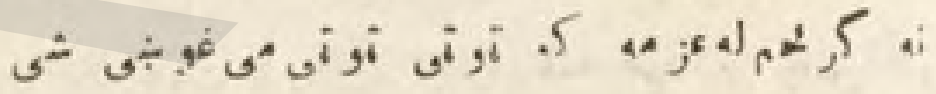

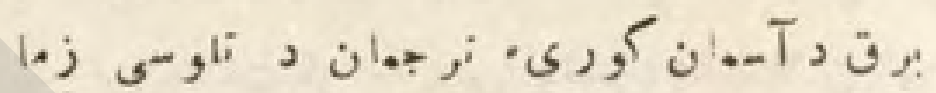

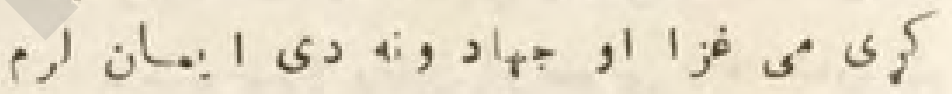

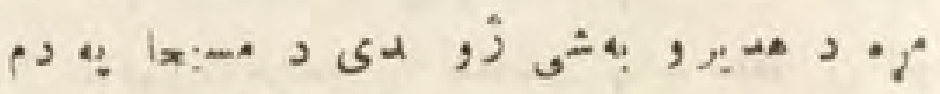
"

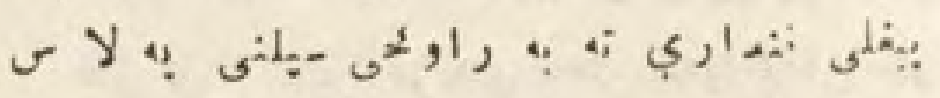
:

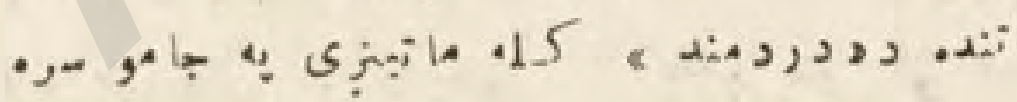

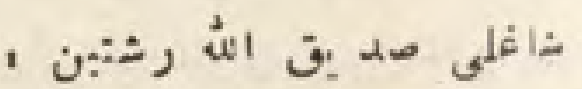

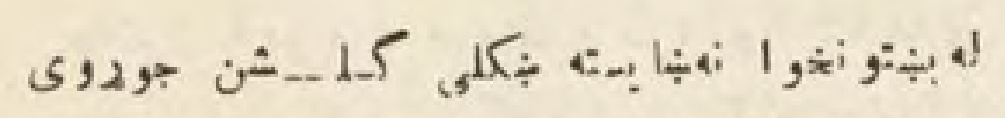

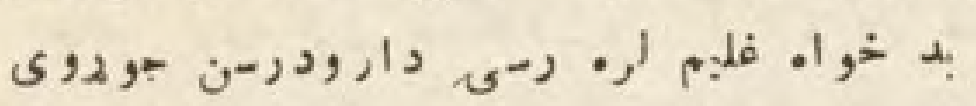

$$
\begin{aligned}
& \text { اوسدى إو •شوى هر يو كار كرى به بوروالى سر. }
\end{aligned}
$$

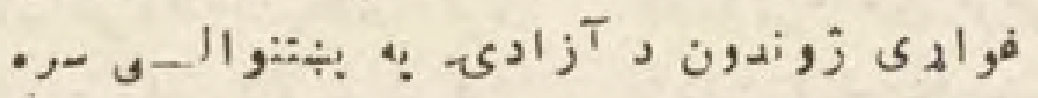

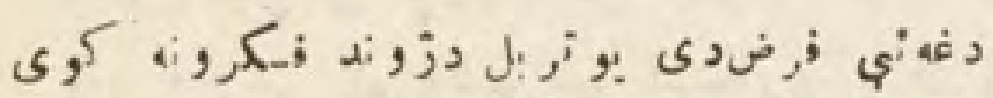

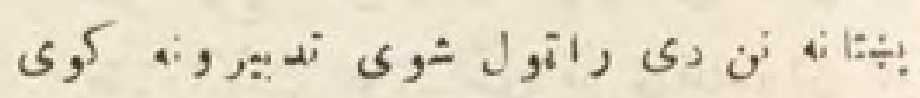

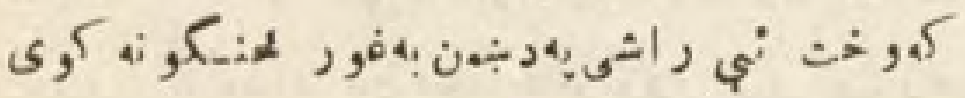

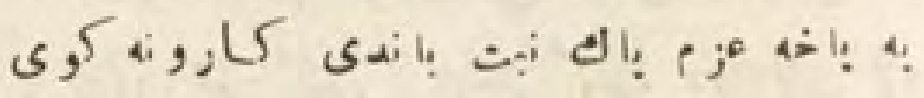

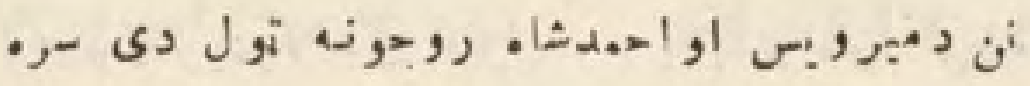

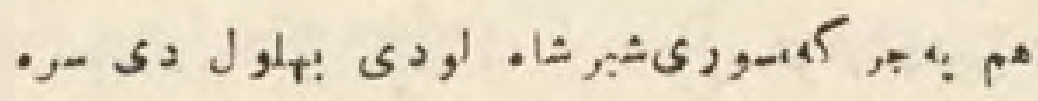

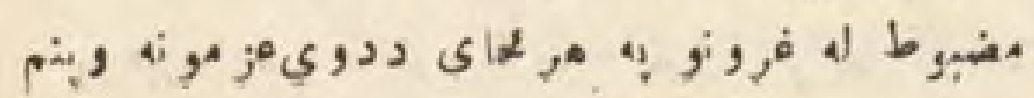




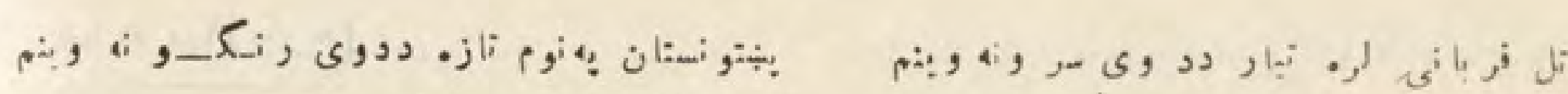

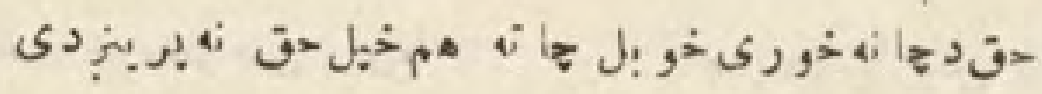

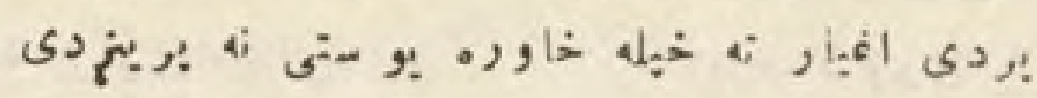

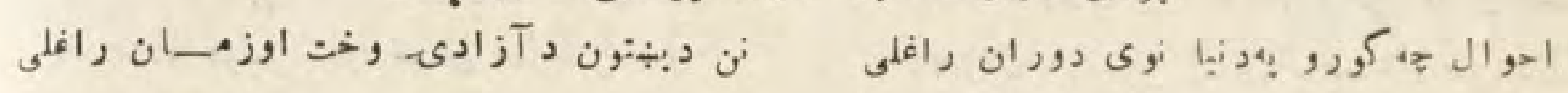

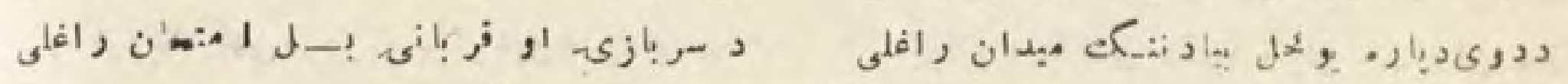

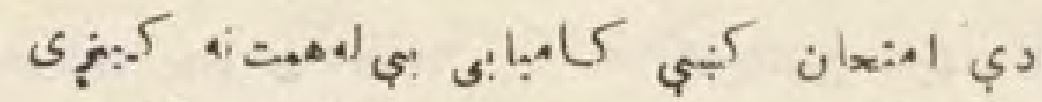

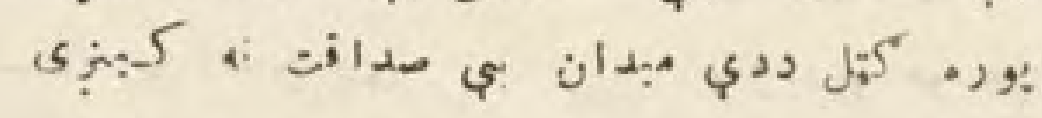

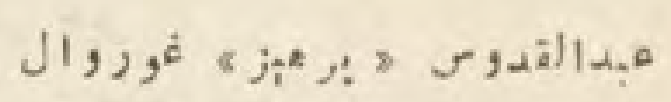 \\ ؟ لز}

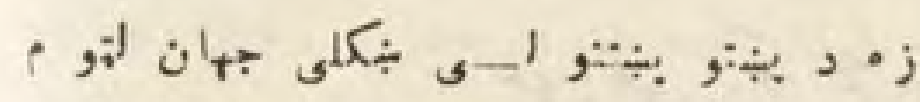

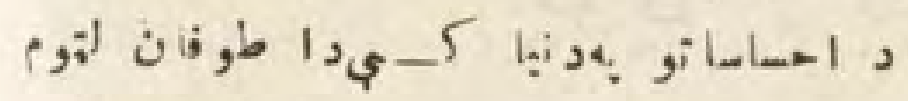

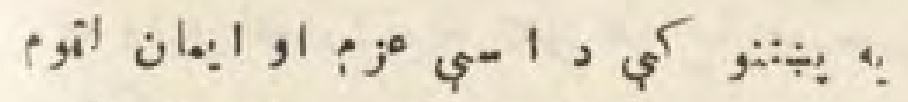

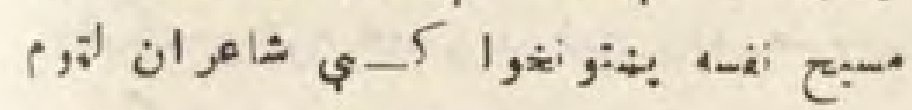

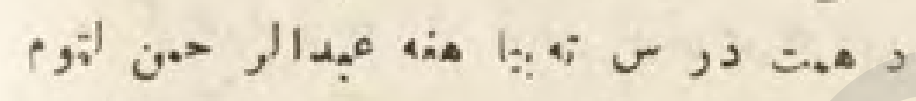

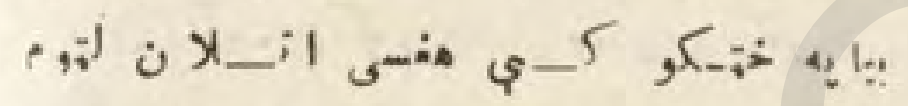

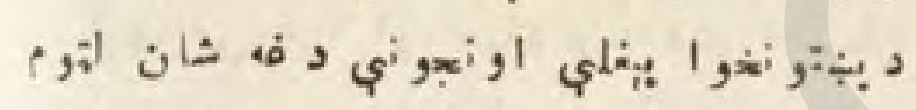

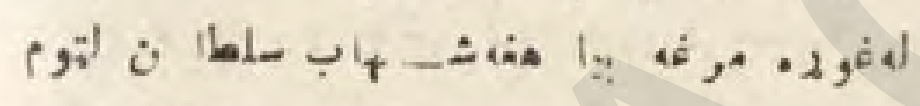

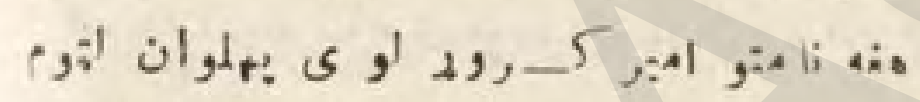

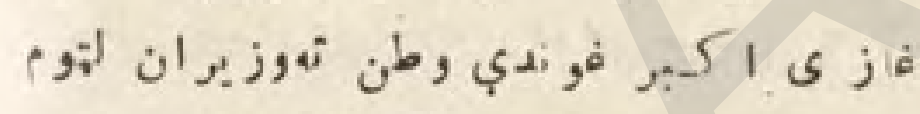

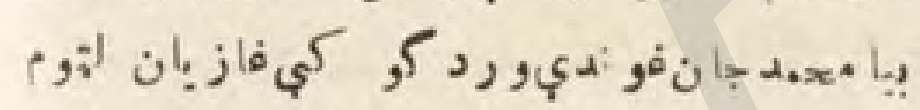

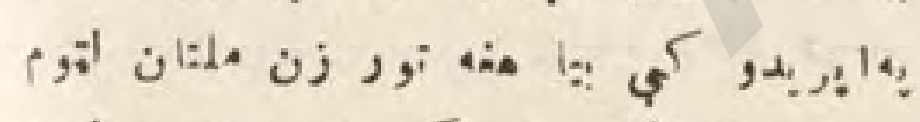

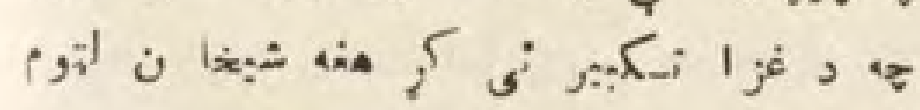

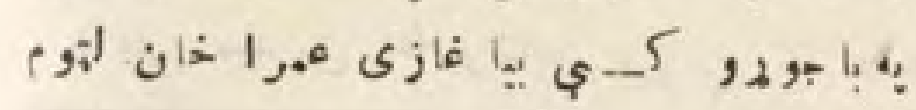

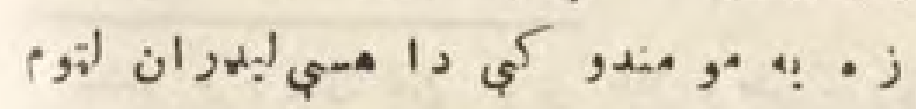

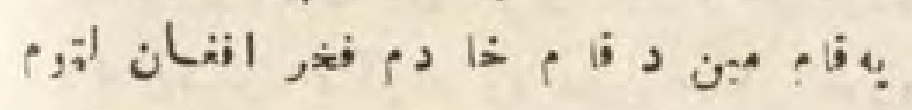

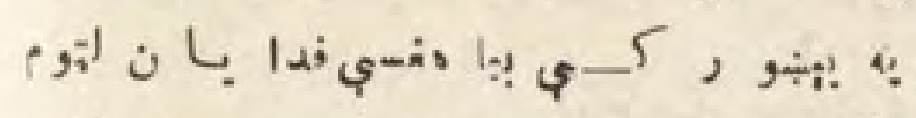

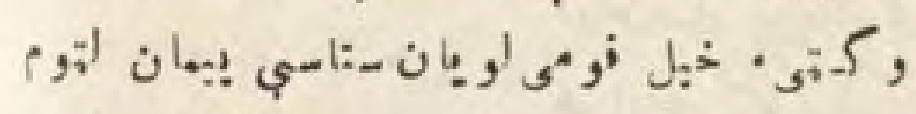

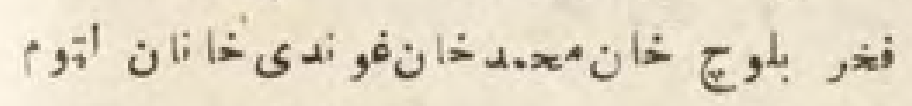

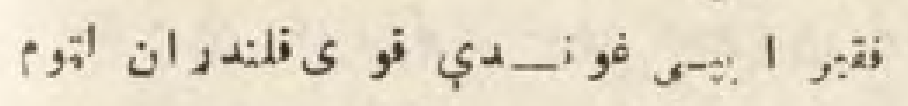

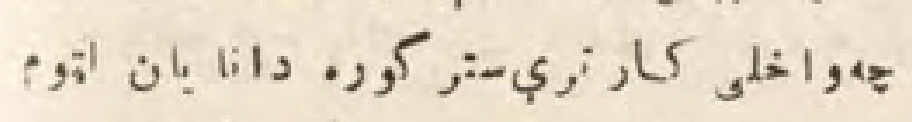

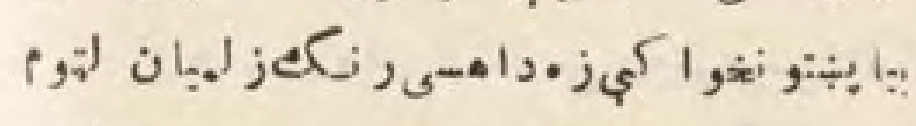

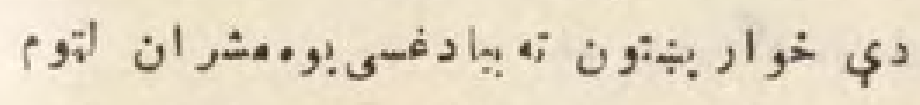

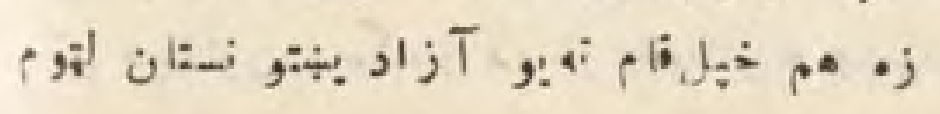

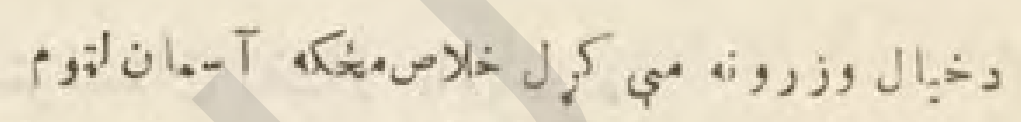

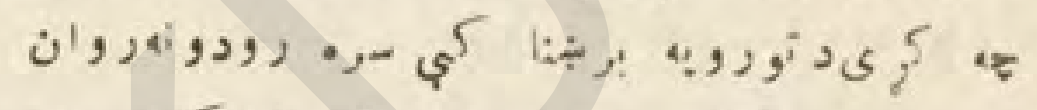

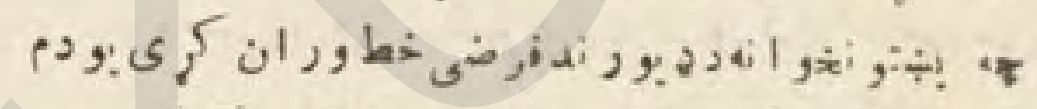

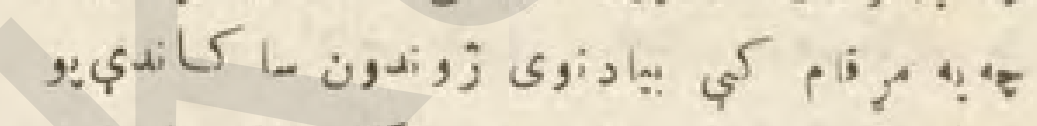
جهدي

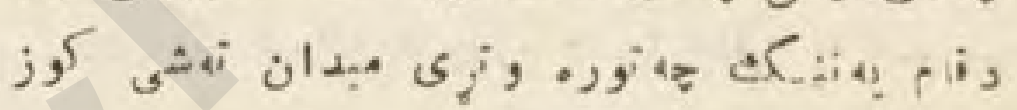

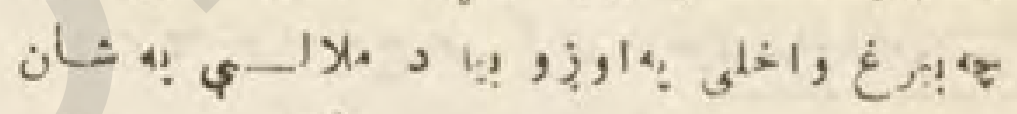

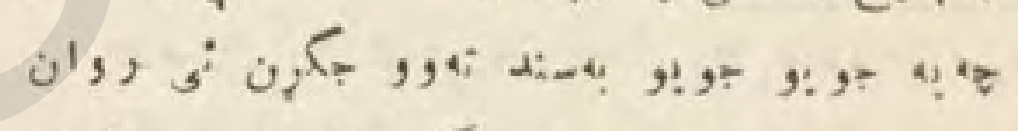

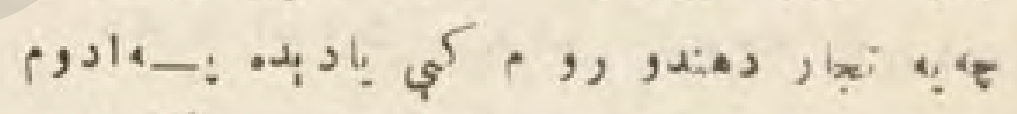

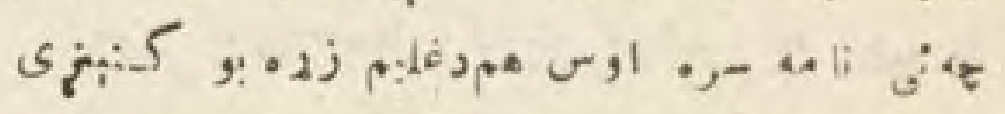

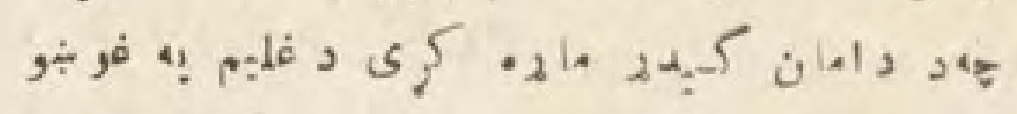

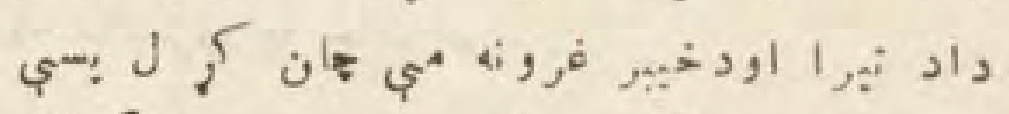
كأم

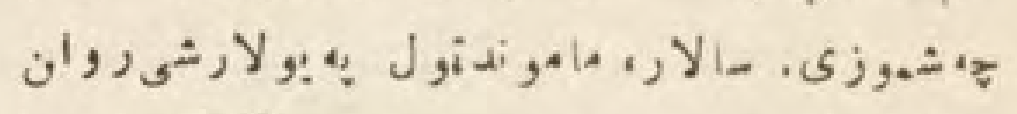

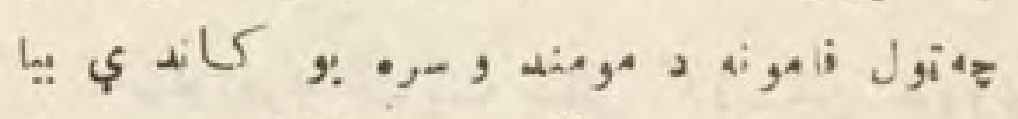

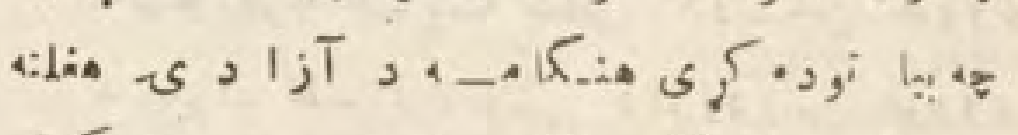

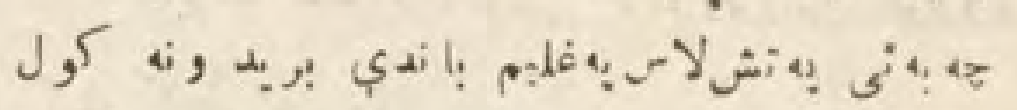

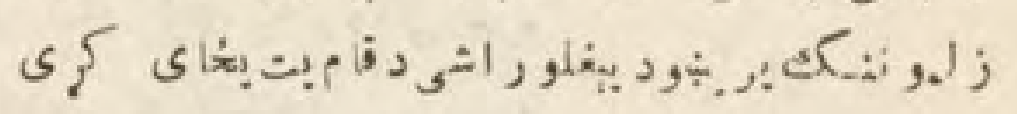

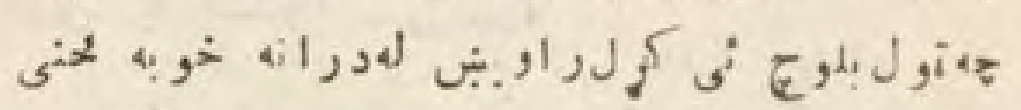

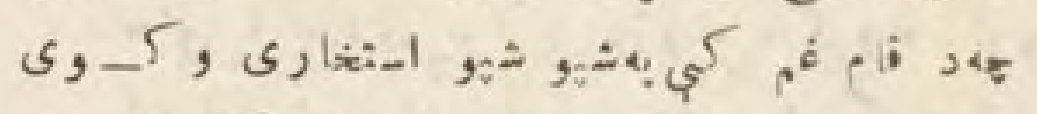

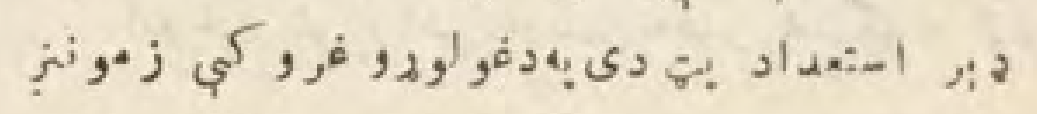

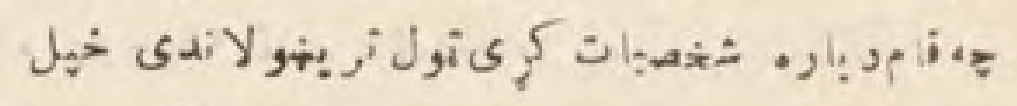

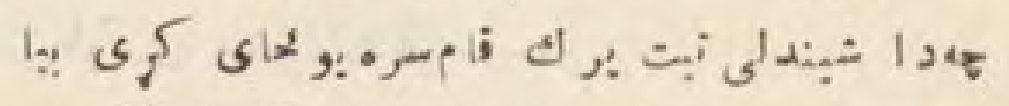

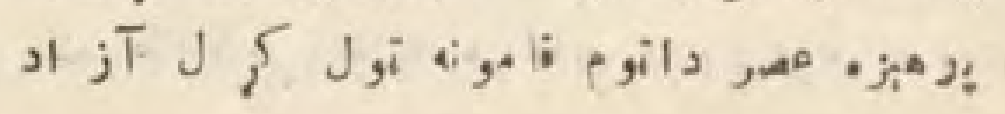




\section{$40 j \div$}

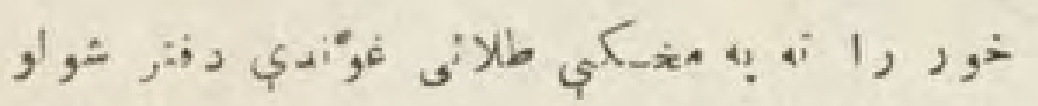

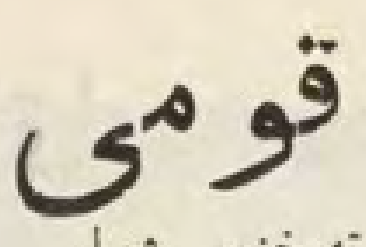

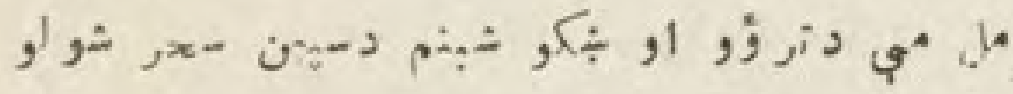

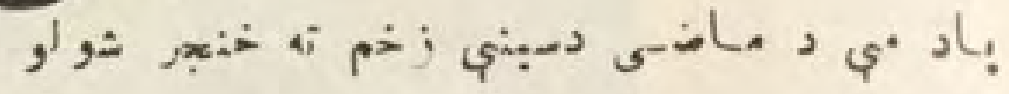

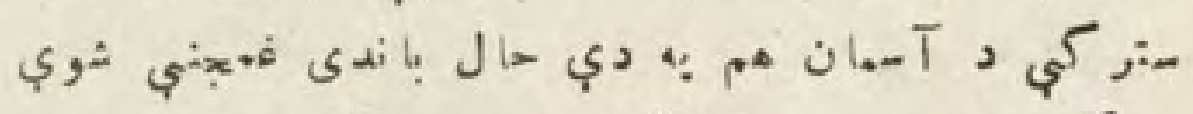

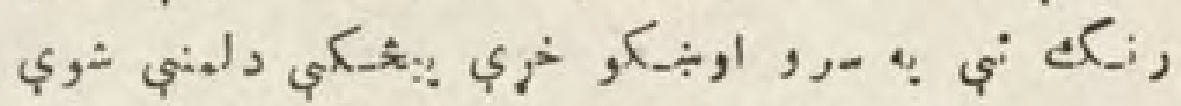

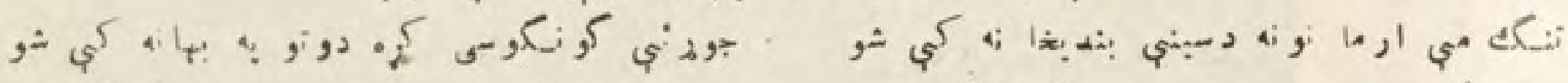

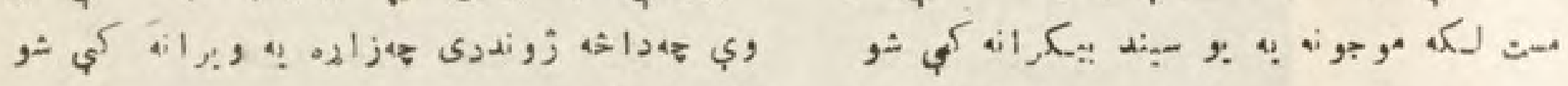

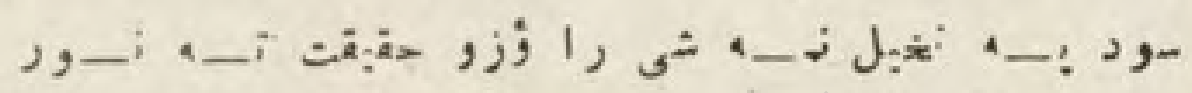

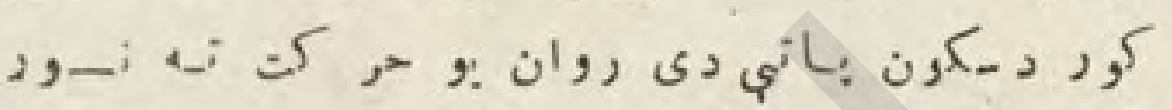

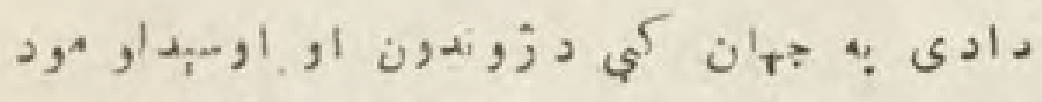

每

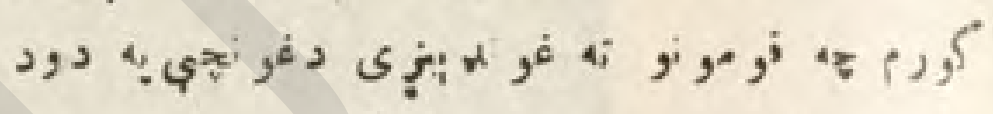

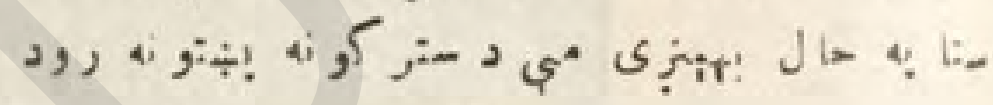

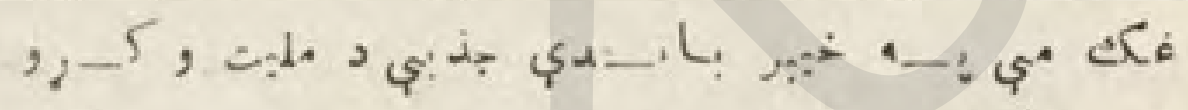

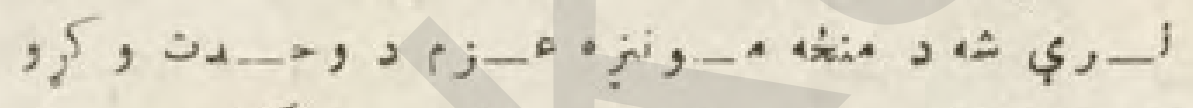

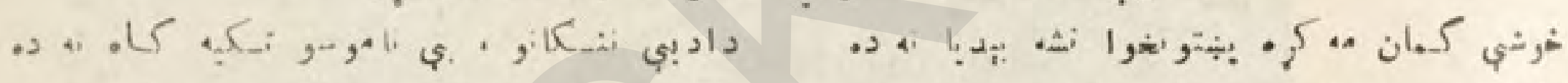

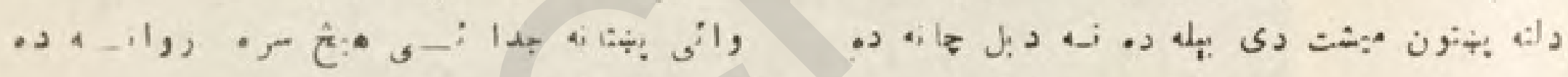

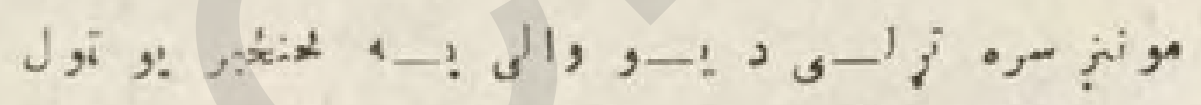

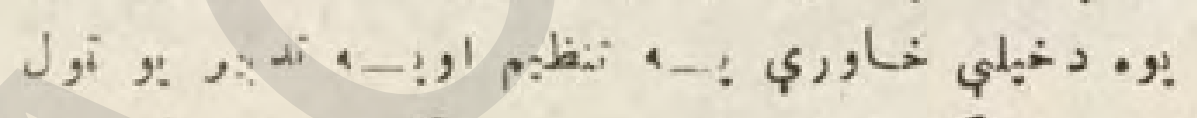

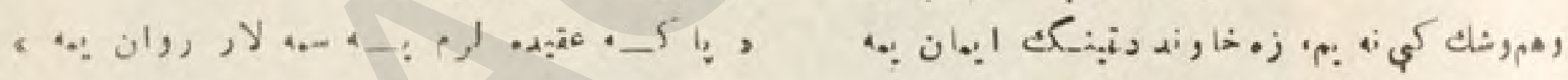

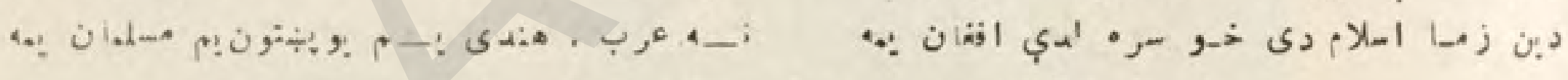

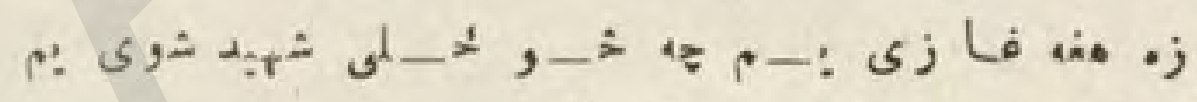

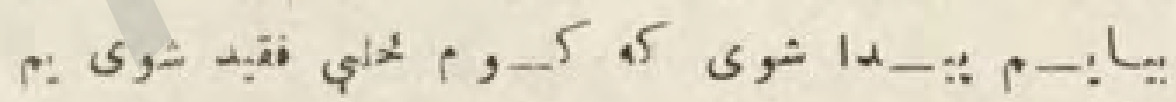

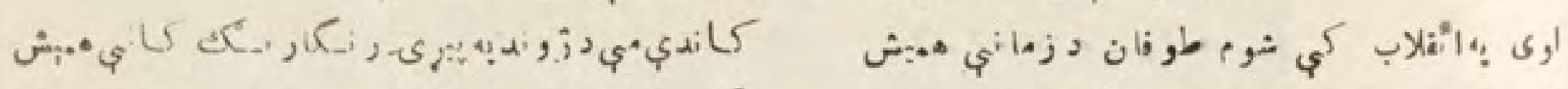

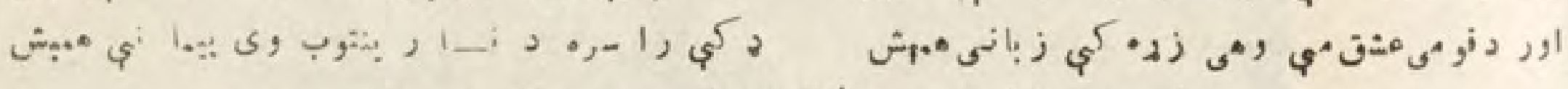

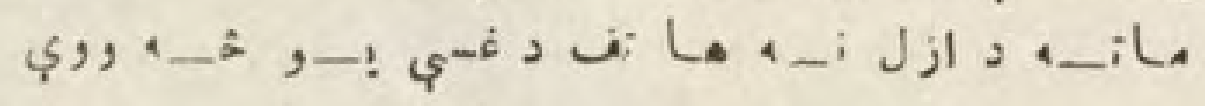

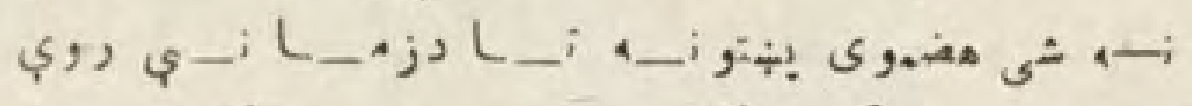

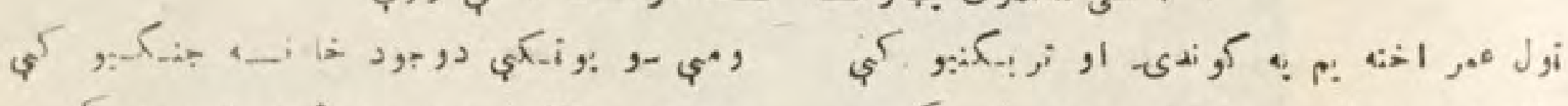

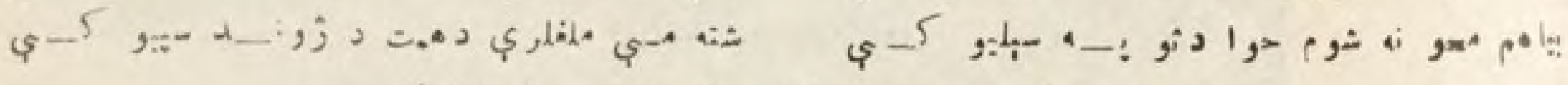

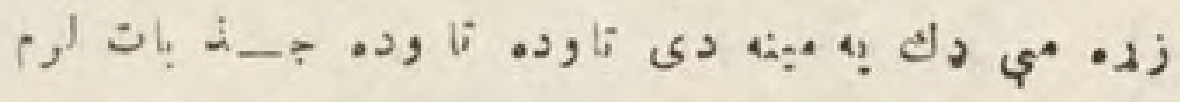

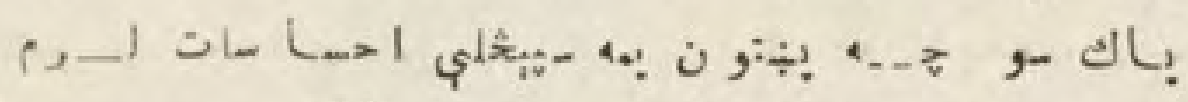

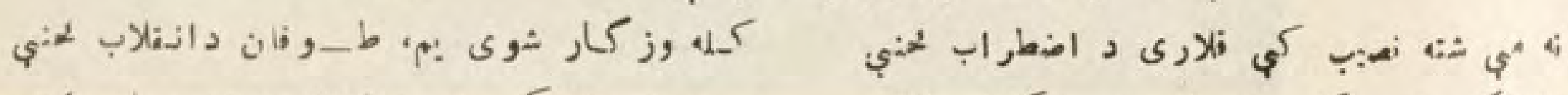

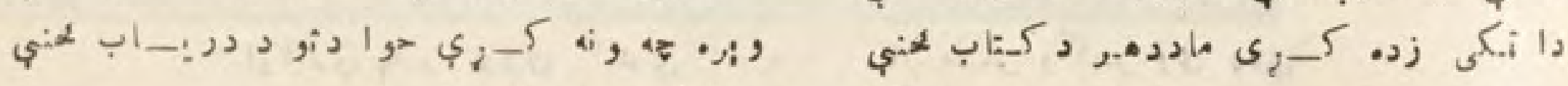

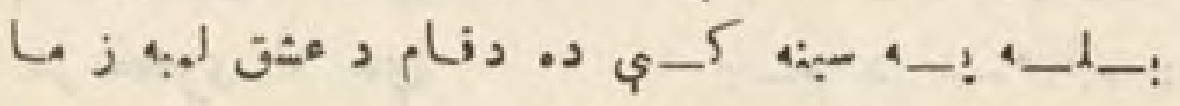

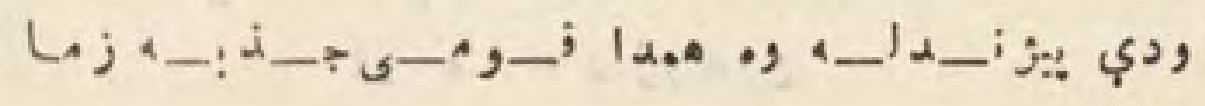


(^)

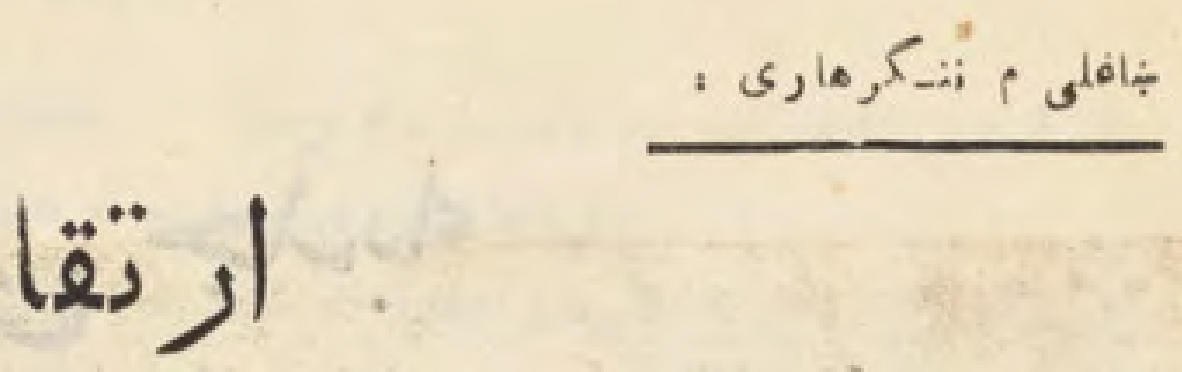

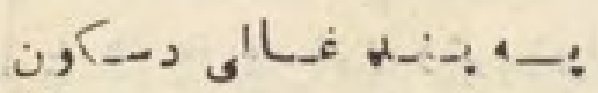

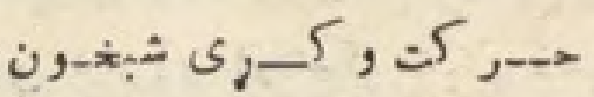

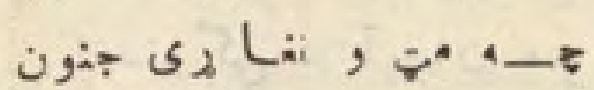

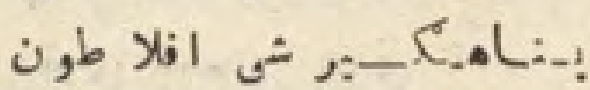

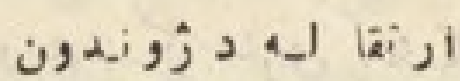

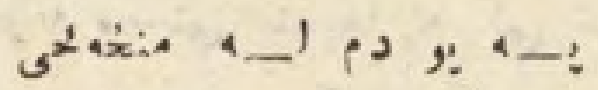

$$
\begin{aligned}
& \text { حواد دثبا شوم اغ-نزى } \\
& \text { الس:هداد شى د.... ع, كر ك ن } \\
& \text { 定 } \\
& \text { ارنقا لــاند دزوندون }
\end{aligned}
$$

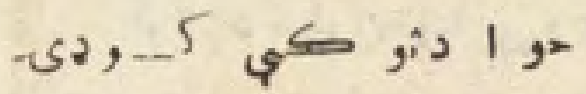

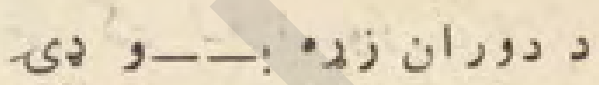

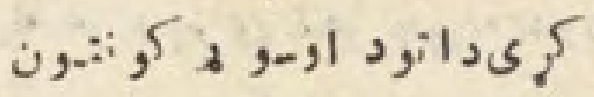

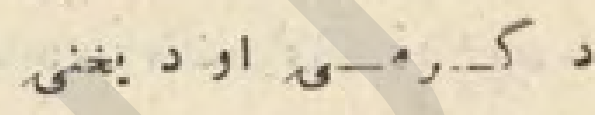

$$
\begin{aligned}
& \text { ار أقال_بدوزوندون }
\end{aligned}
$$

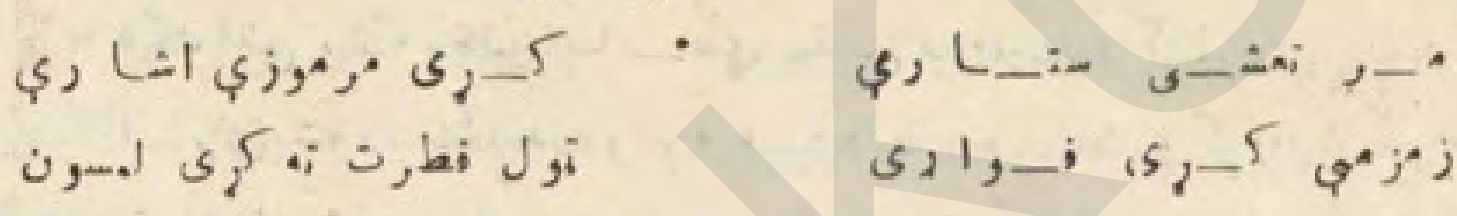

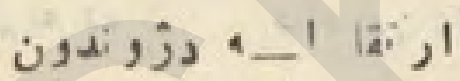

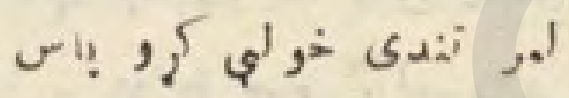

$$
\begin{aligned}
& \text { هـiار بهز }
\end{aligned}
$$

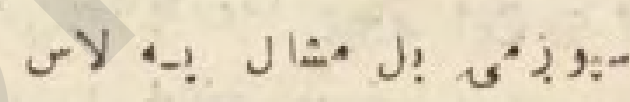

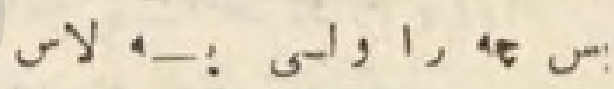

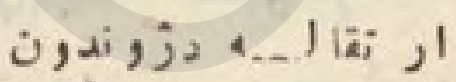

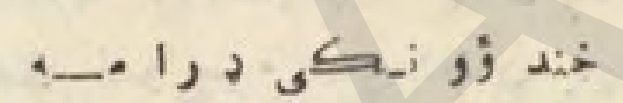

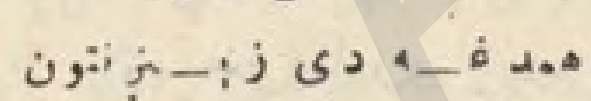

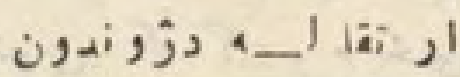

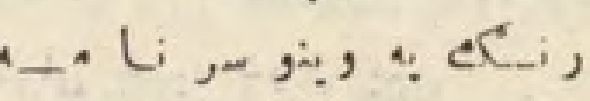

$$
\begin{aligned}
& \text { انة_ابلاب طـ_, أهـرو, }
\end{aligned}
$$

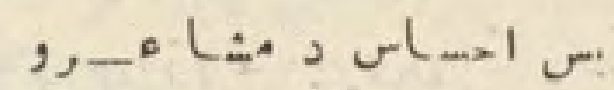

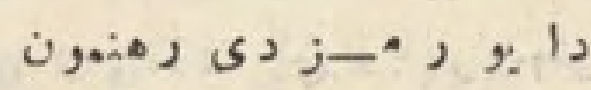

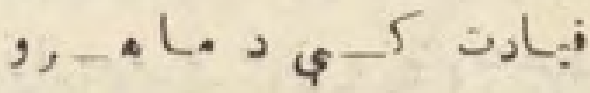

$$
\begin{aligned}
& \text { ار ارة الها لهد ز أندون }
\end{aligned}
$$

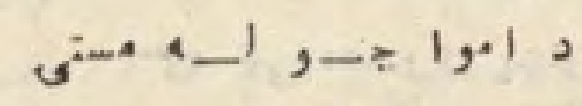

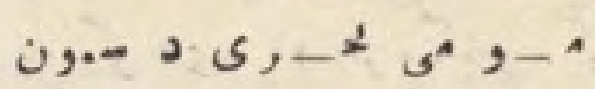

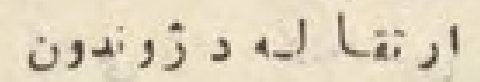

$$
\begin{aligned}
& \text { ئil, }
\end{aligned}
$$

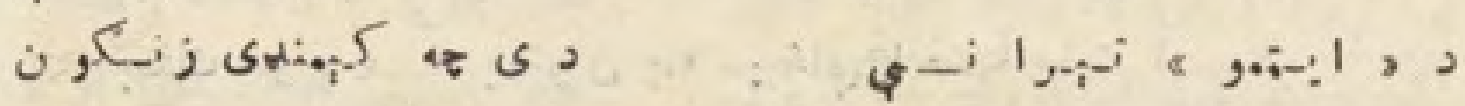

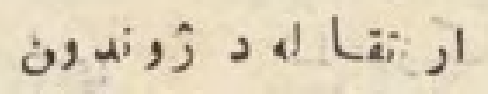

$$
\begin{aligned}
& \text { ار هـان ,كـر وى دوي لدي }
\end{aligned}
$$

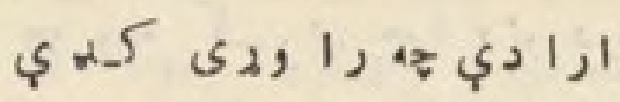

$$
\begin{aligned}
& \text { أ:- }
\end{aligned}
$$

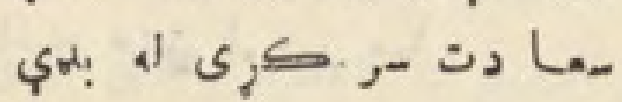

$$
\begin{aligned}
& \text { ار iالما له دزو ندون }
\end{aligned}
$$

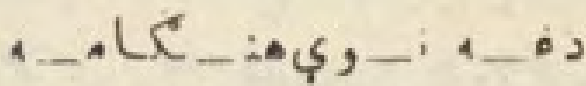




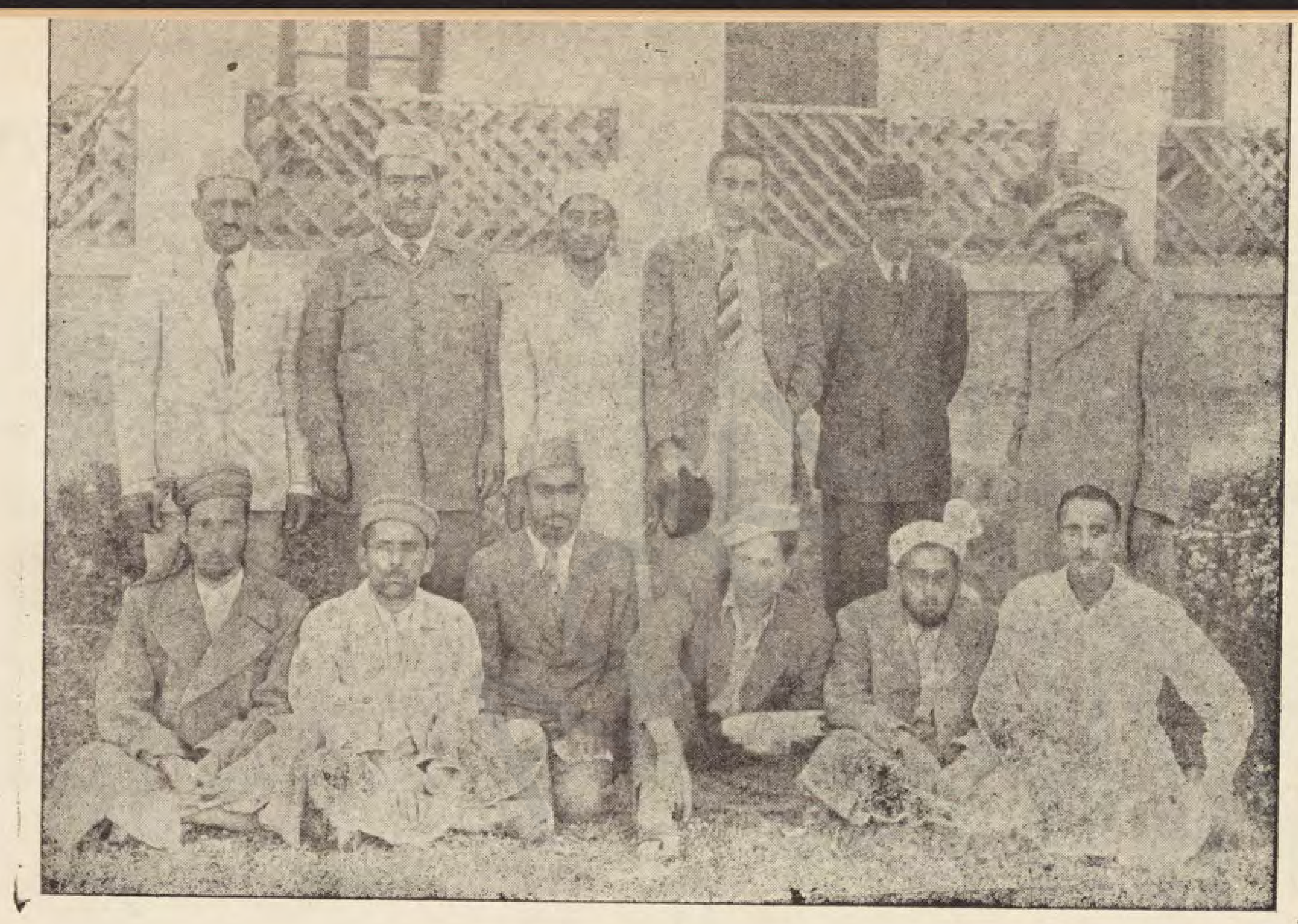

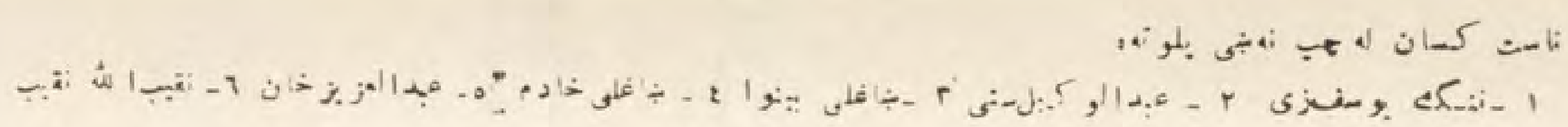

int 
(4)

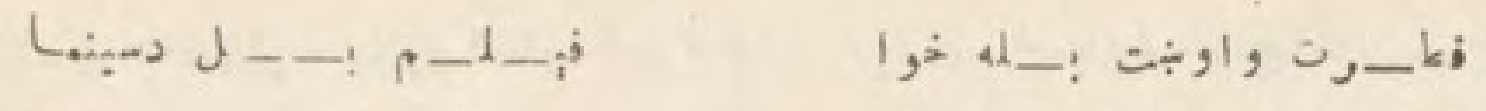

$$
\begin{aligned}
& \text { ن } \\
& \text { ن }
\end{aligned}
$$

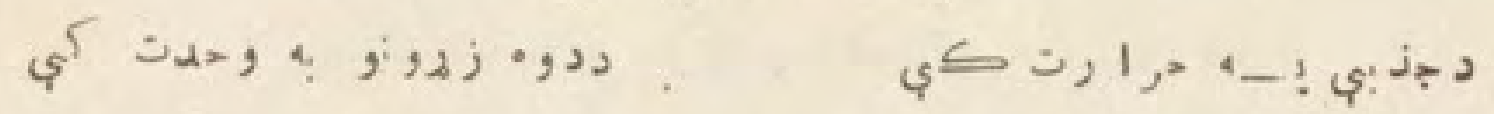

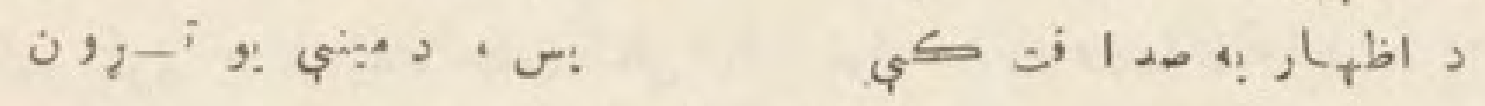

$$
\begin{aligned}
& \text { ند, }
\end{aligned}
$$

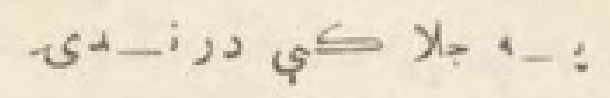

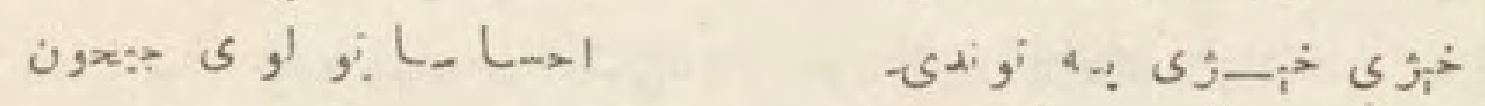

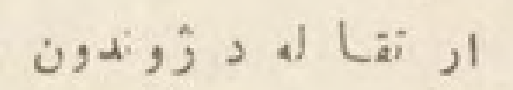

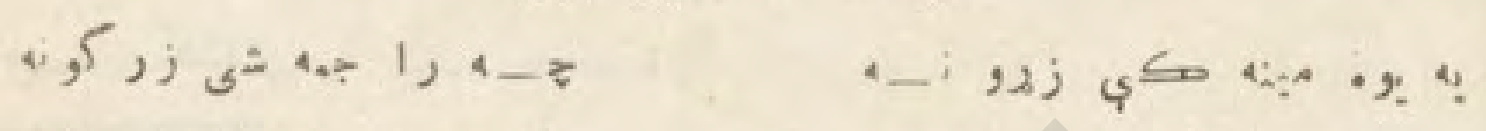

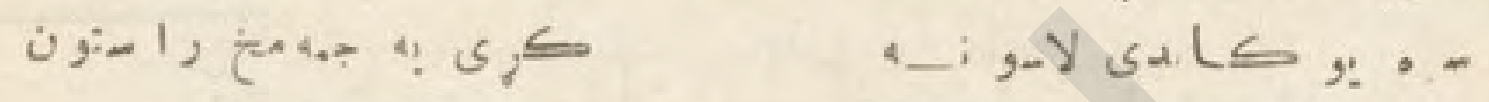

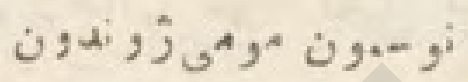

$$
\begin{aligned}
& \text {, - i L } L_{t}, 2_{p} \leq 1, \ldots
\end{aligned}
$$

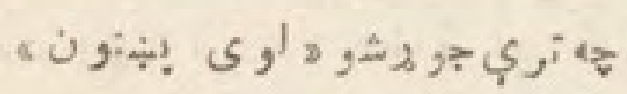

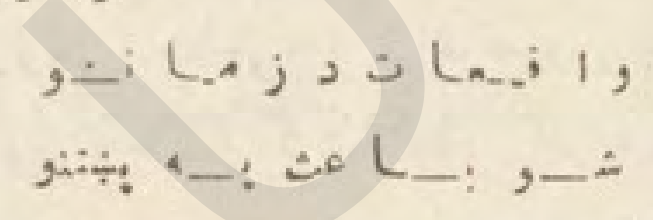

$$
\text { فخر ديُبتوندى ترابدهنى مهمتازلري }
$$

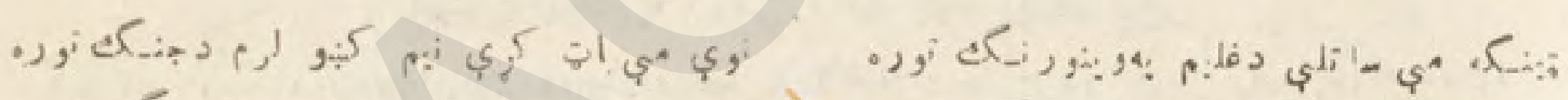

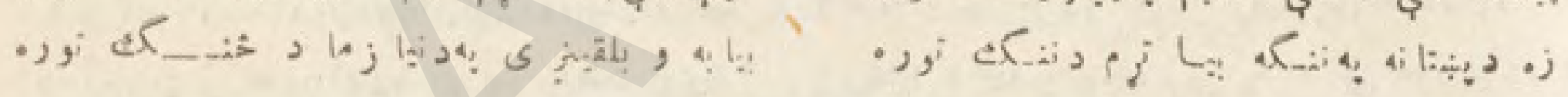

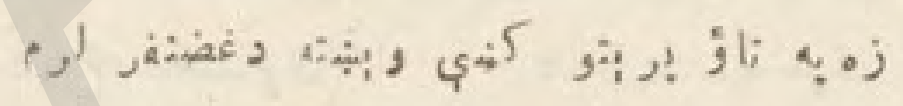

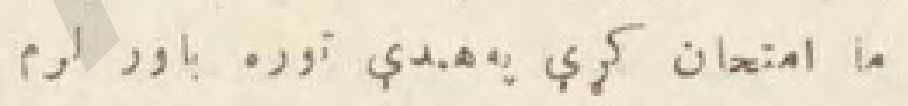

(ब)

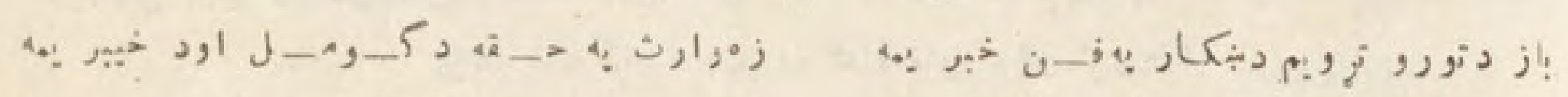

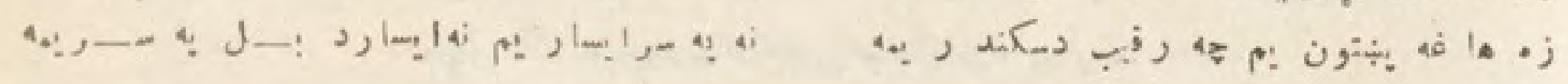

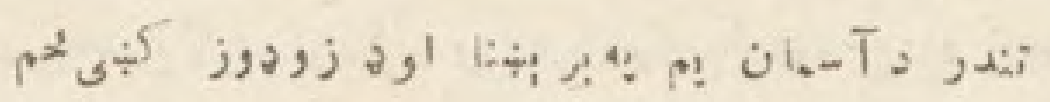

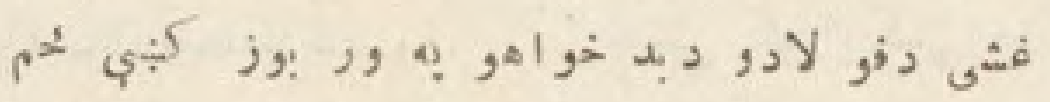

$$
\begin{aligned}
& \text { (6) } 6
\end{aligned}
$$

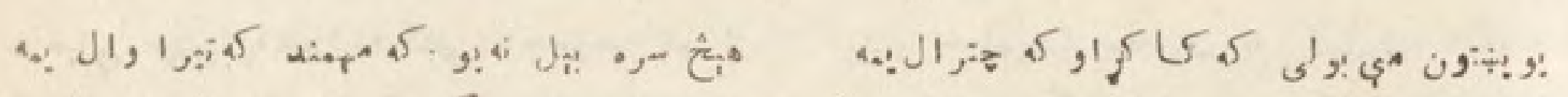

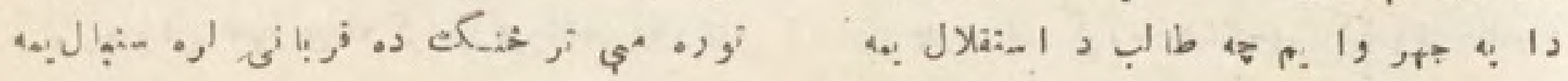

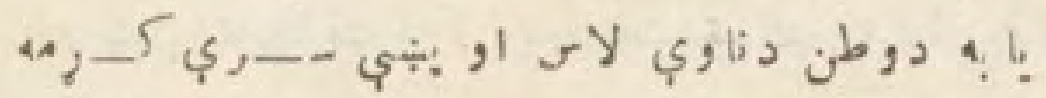

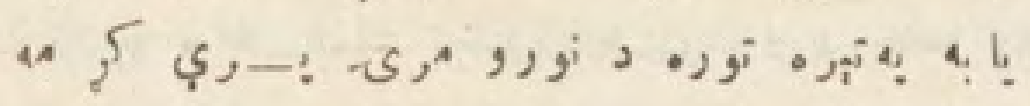

$$
\text { (9) }
$$

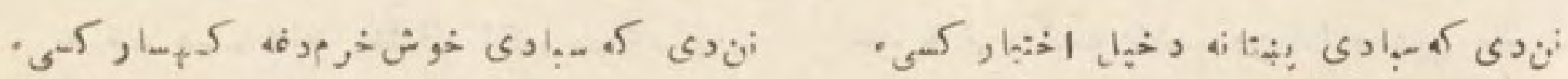




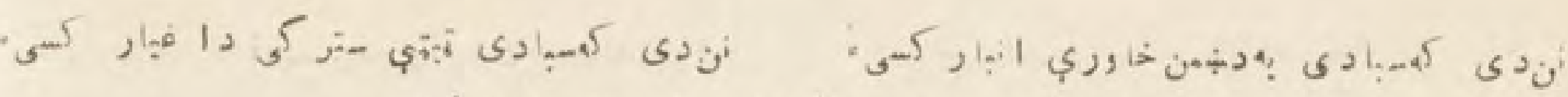

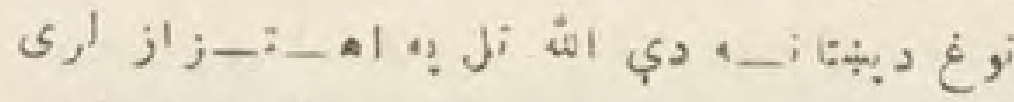

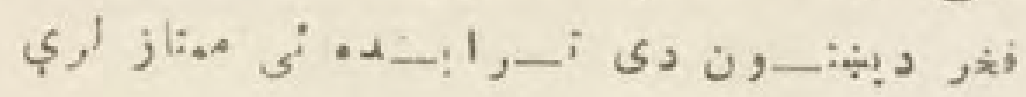

(9) 6

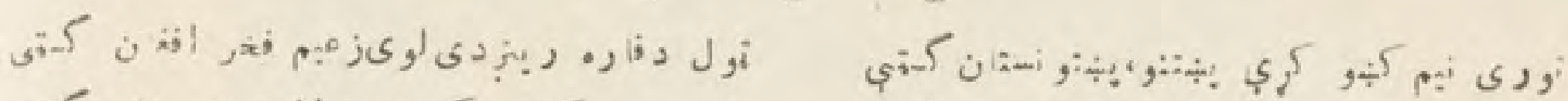

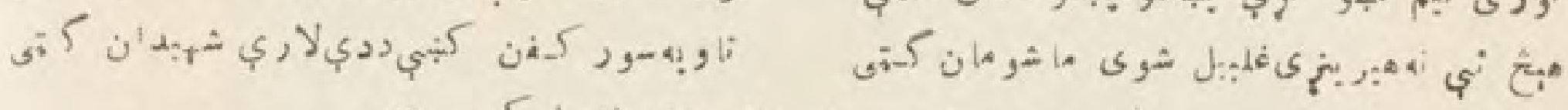
4

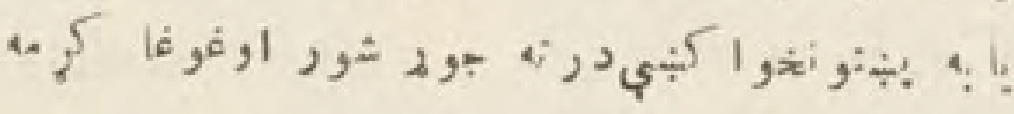

بن

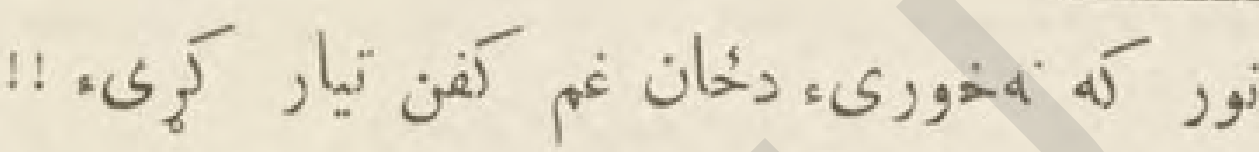

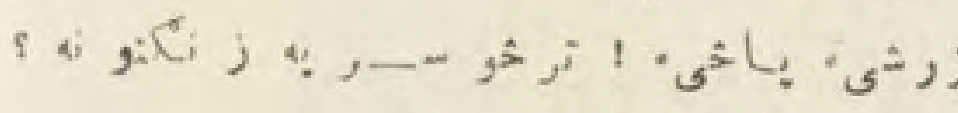

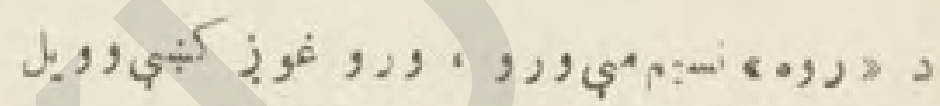

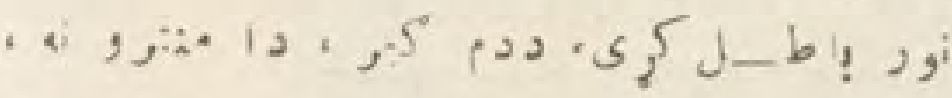

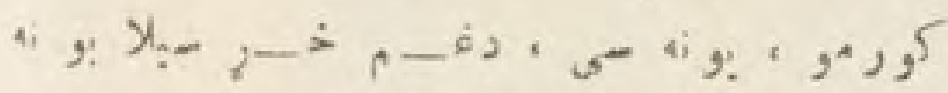

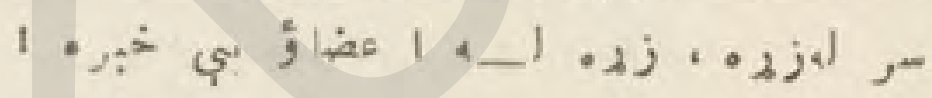

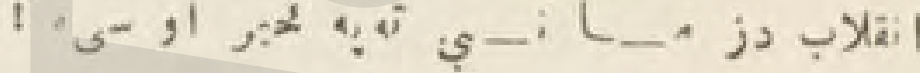

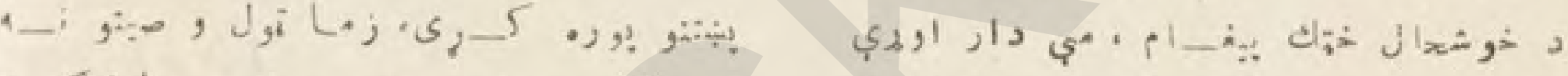

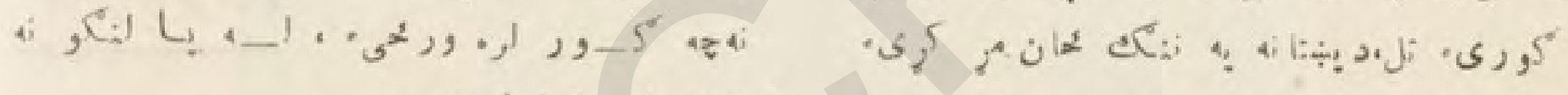

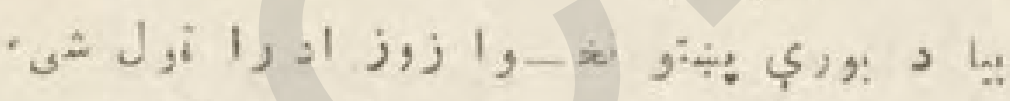

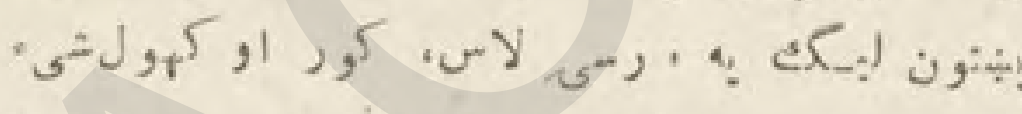

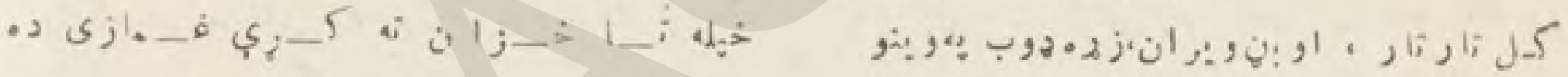

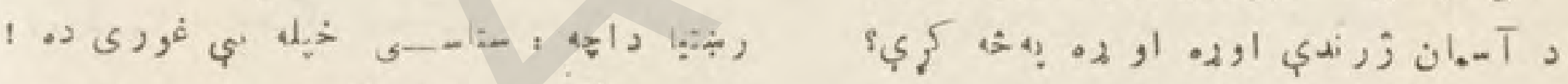

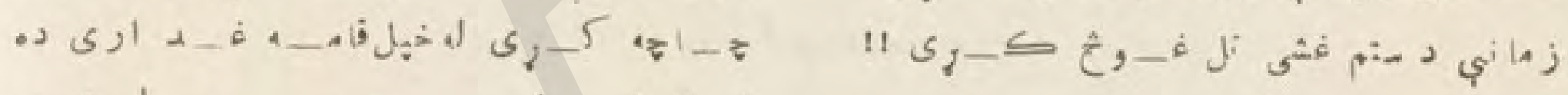

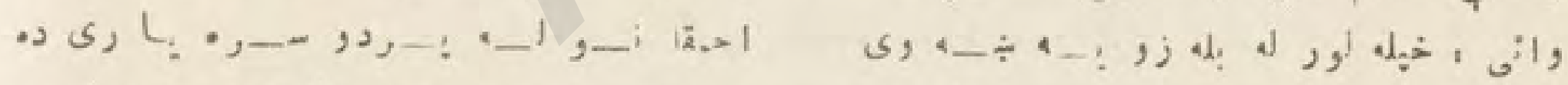

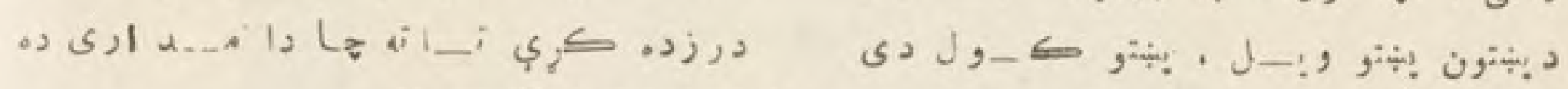

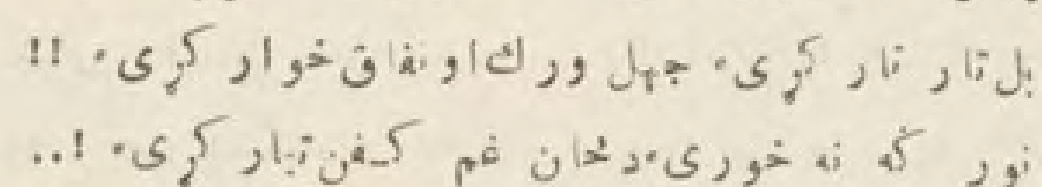

روى خدائ

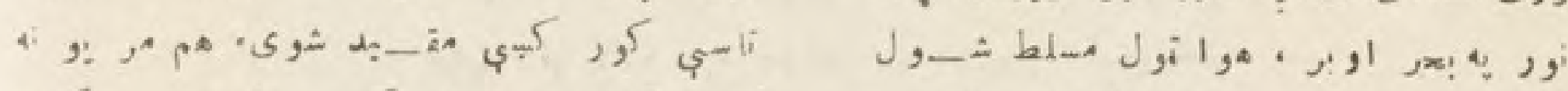

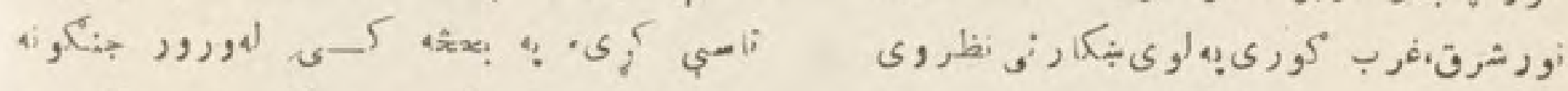

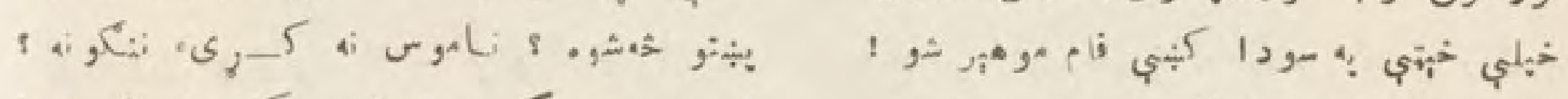

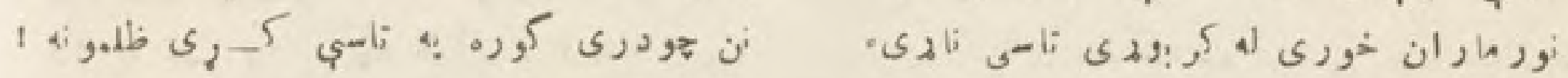

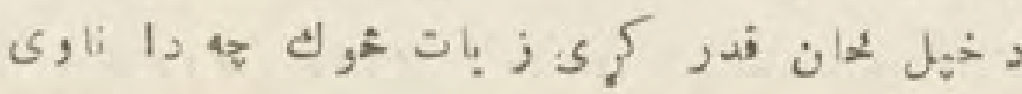

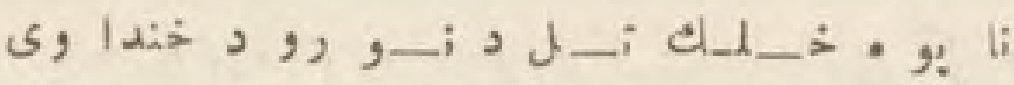

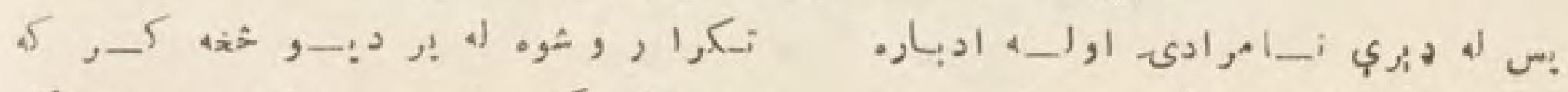

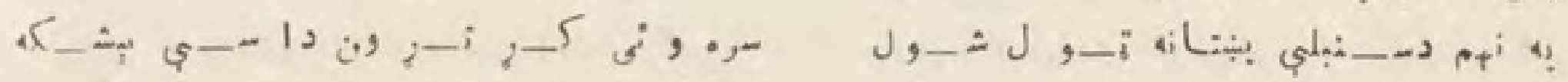




$$
\begin{aligned}
& \text { ج } \\
& \text { شورى كان }
\end{aligned}
$$

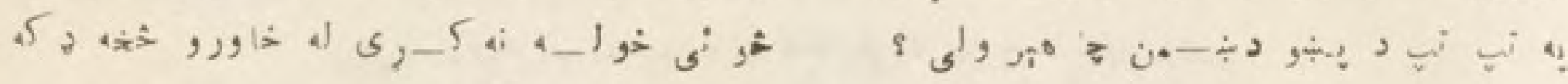

$$
\begin{aligned}
& \text {. }
\end{aligned}
$$

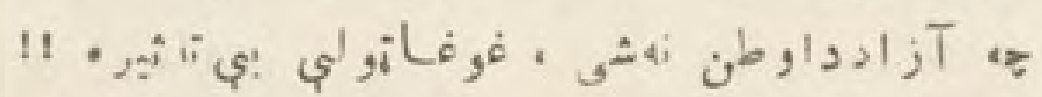

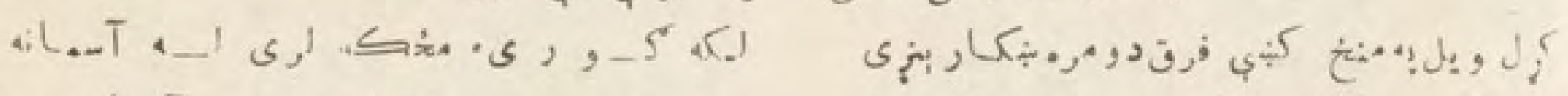

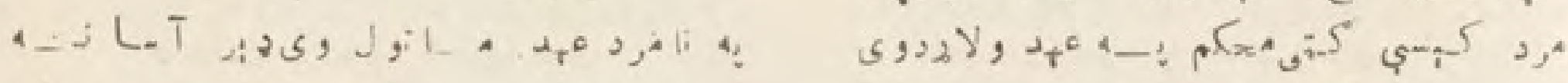

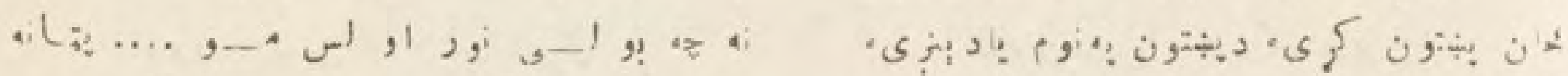

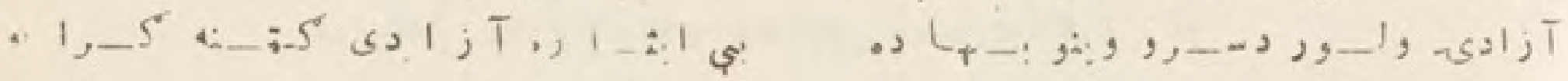

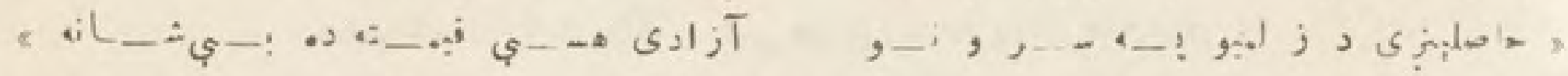

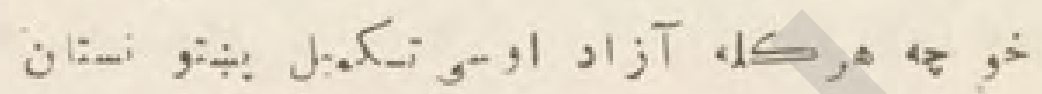

$$
\begin{aligned}
& \text { : }
\end{aligned}
$$

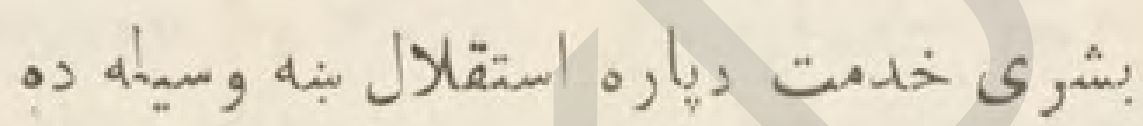

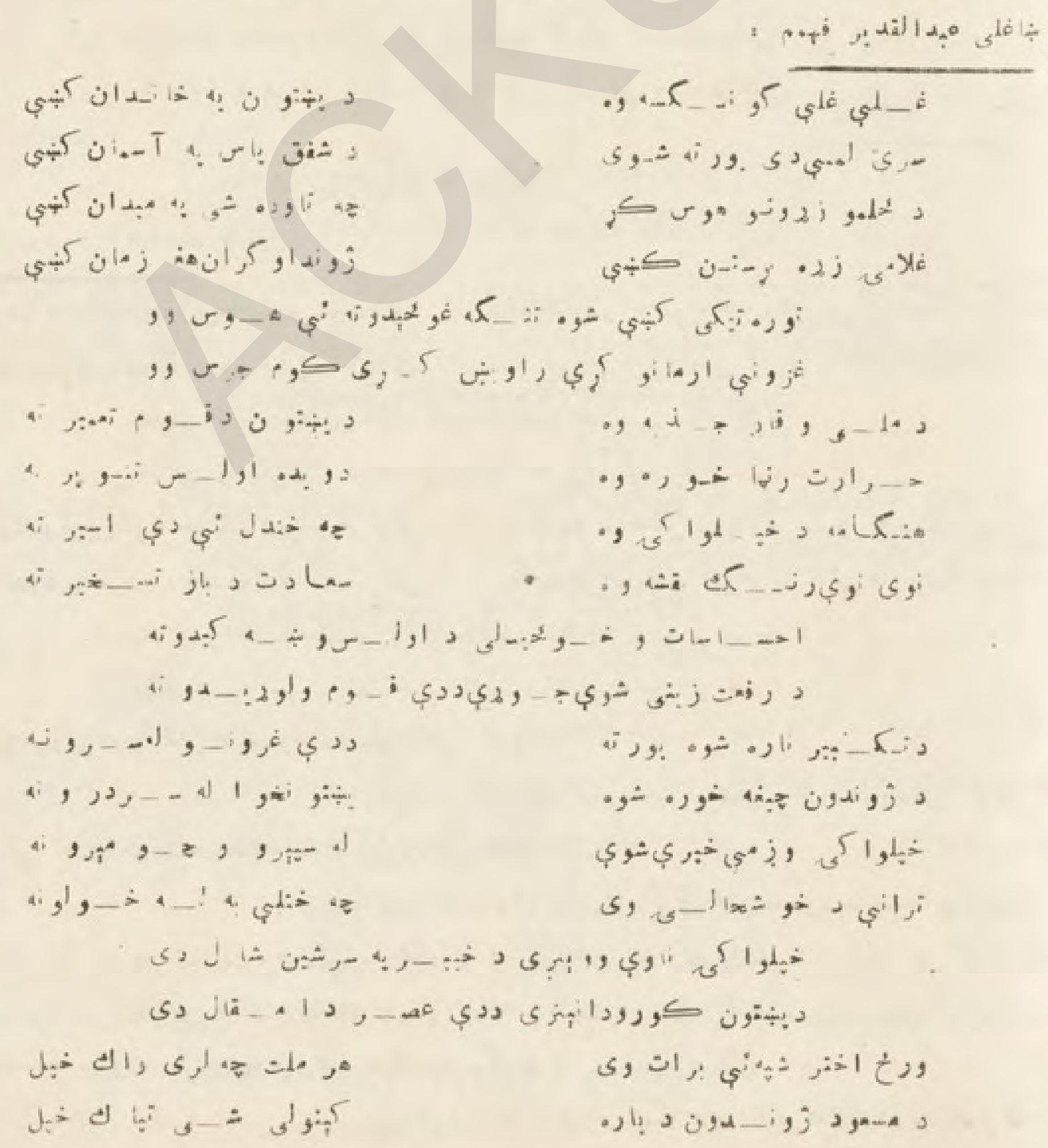


(ir)

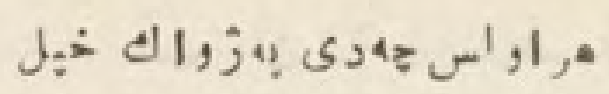

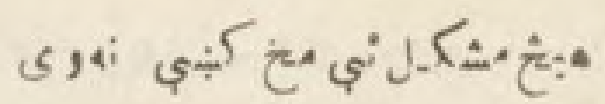

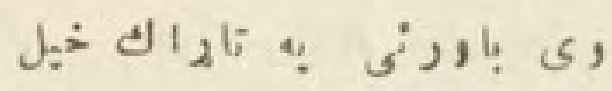

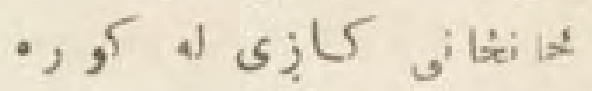

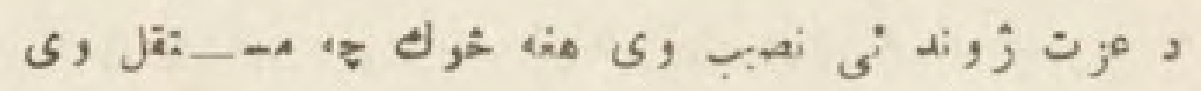

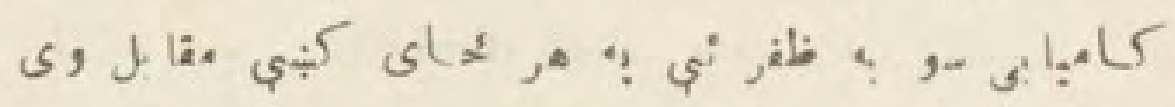

ز

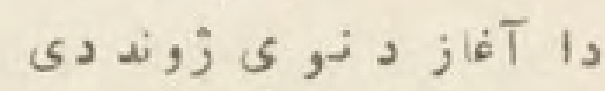

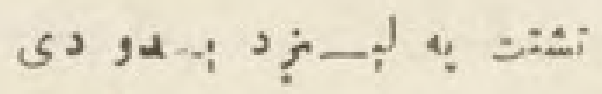

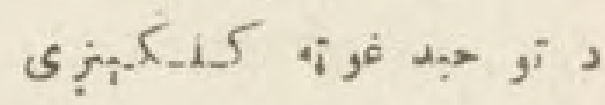

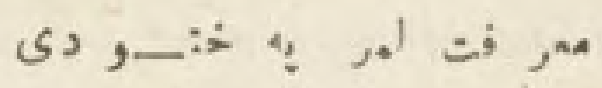

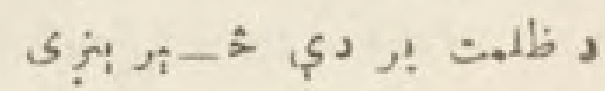

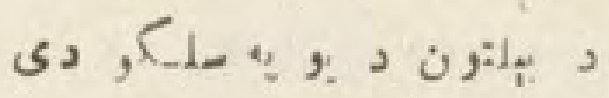

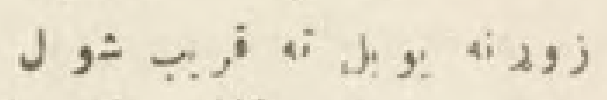

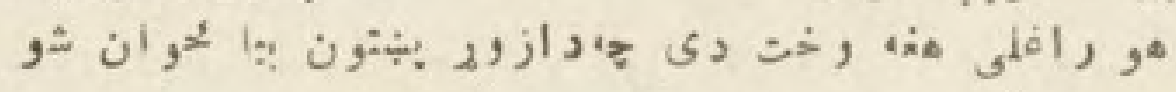

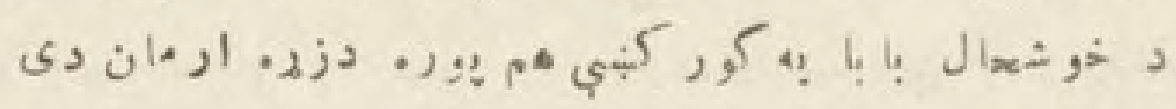

.

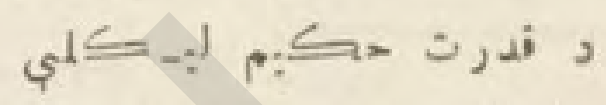

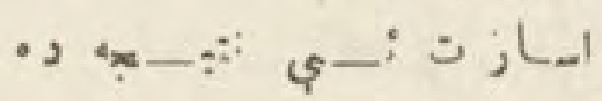

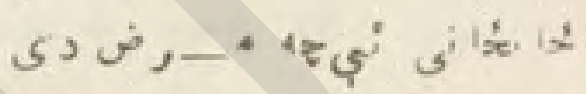

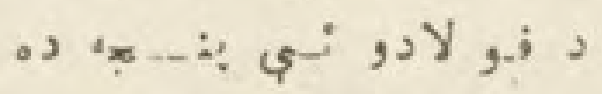

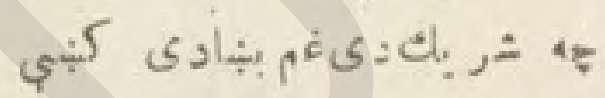

ه

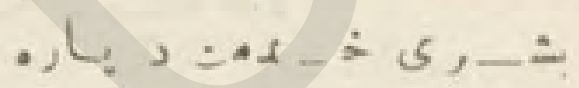

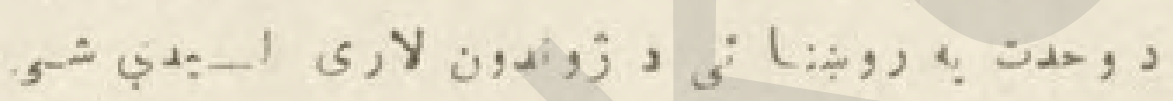

قي

$\Gamma^{\prime} \log$

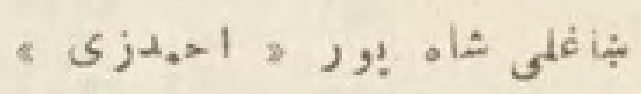

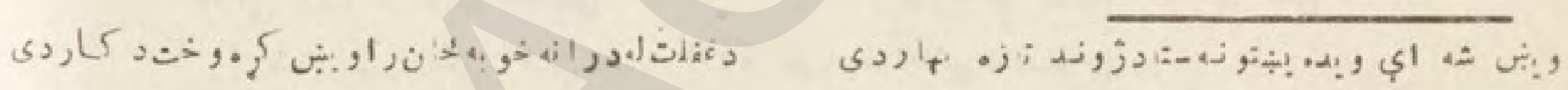

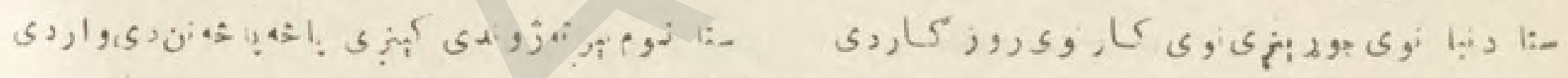

i,

•

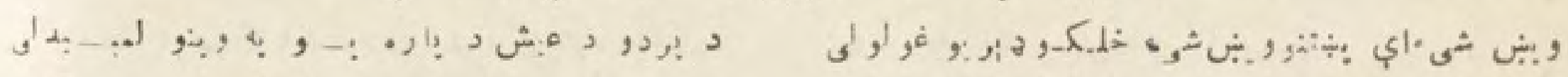

ن

$\therefore$ :

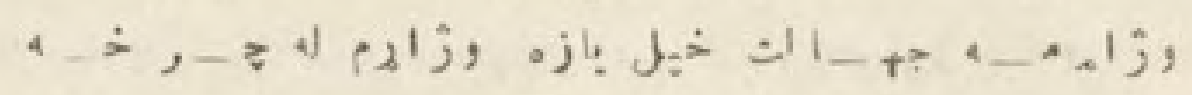

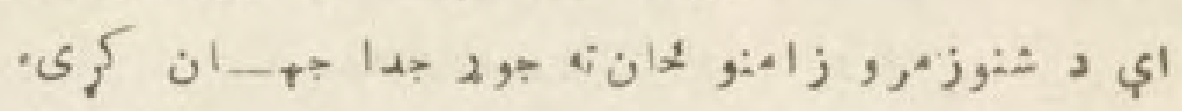

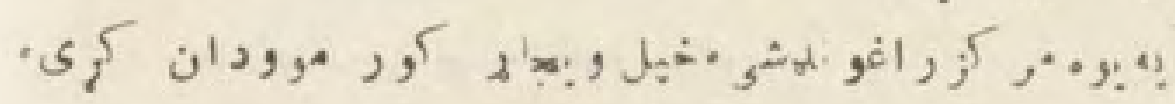

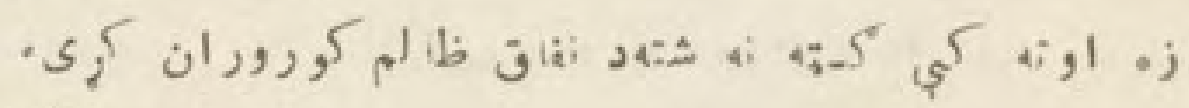

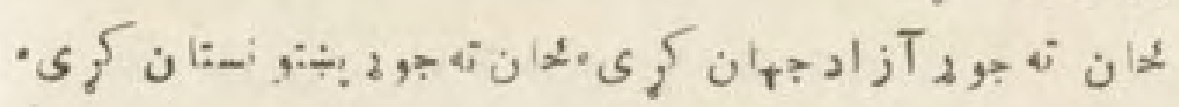

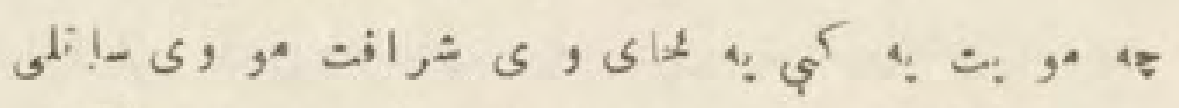

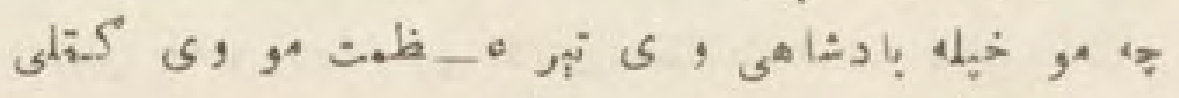

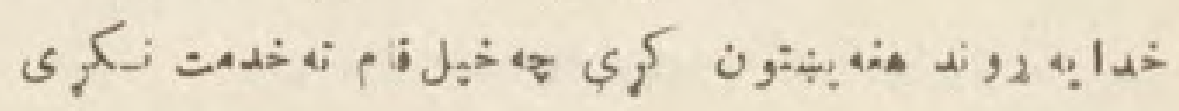

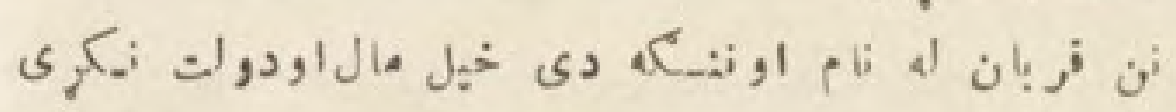




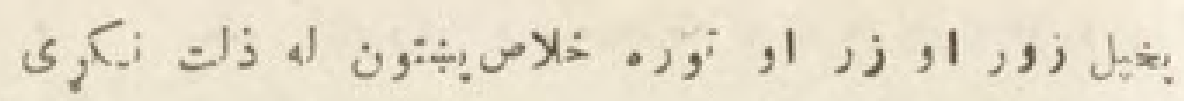

ى

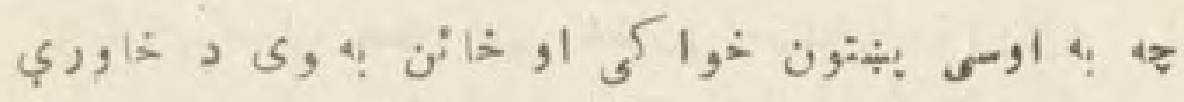

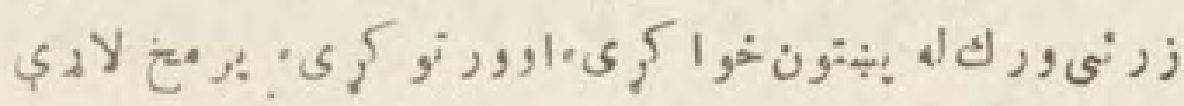

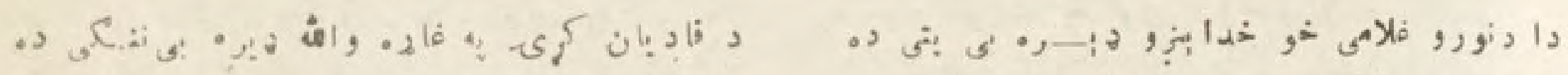

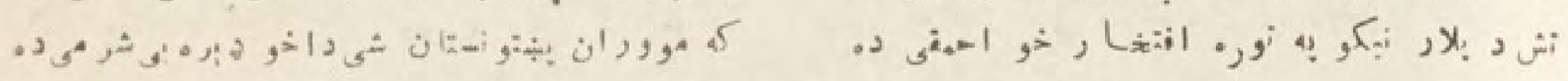

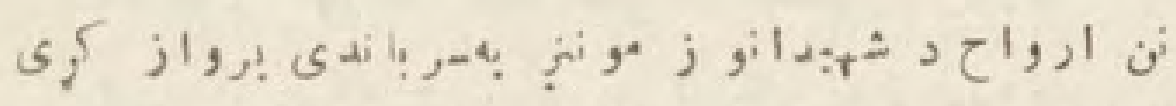

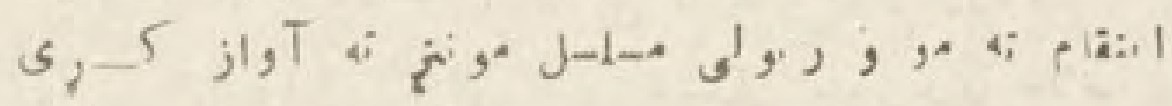

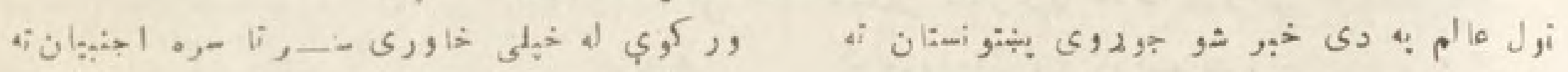

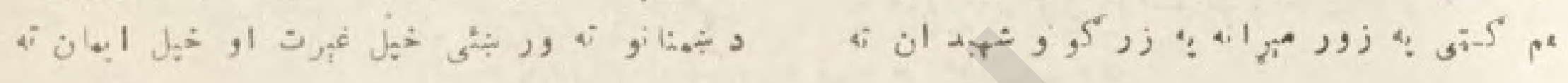

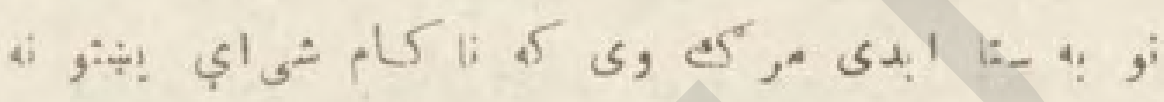

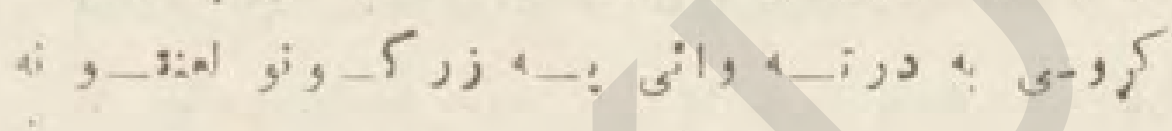

$$
\begin{aligned}
& 1, \hat{j} a
\end{aligned}
$$

\& ب ب

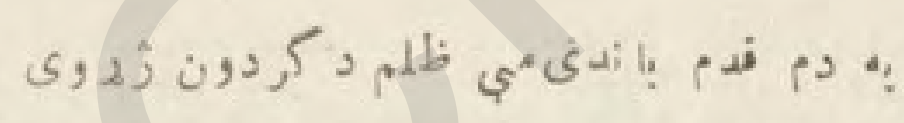

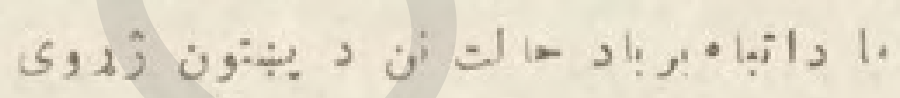

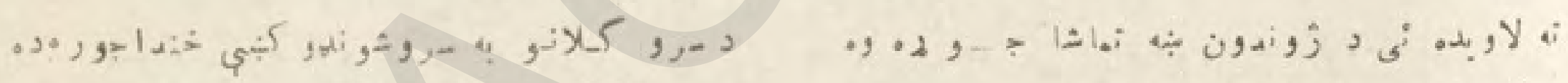

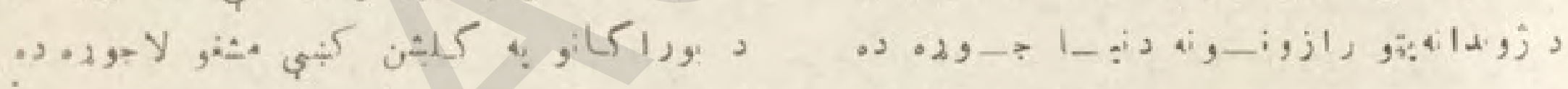

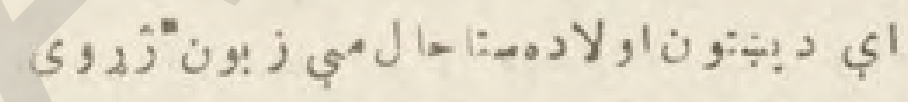

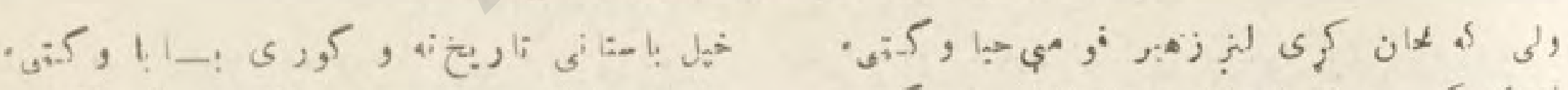

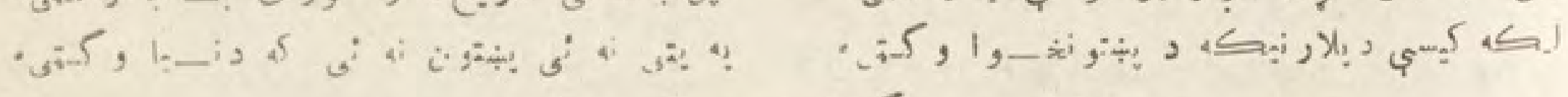

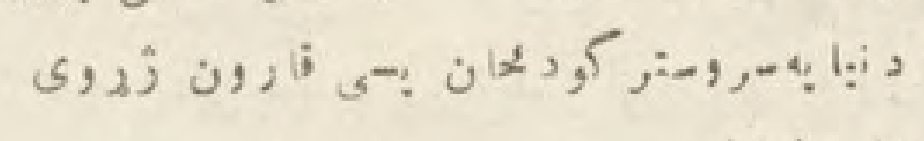

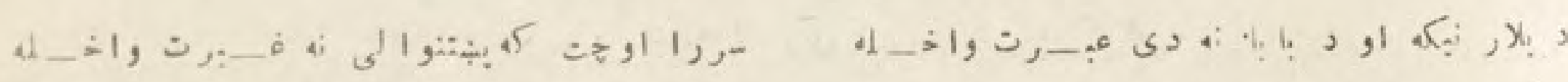

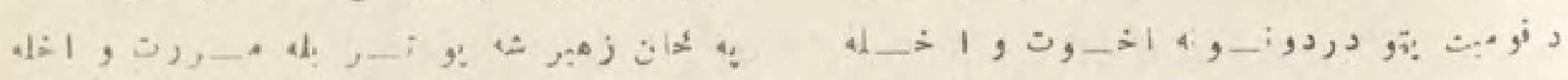

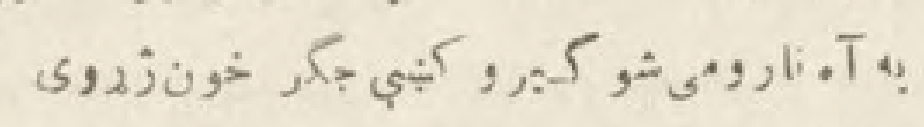

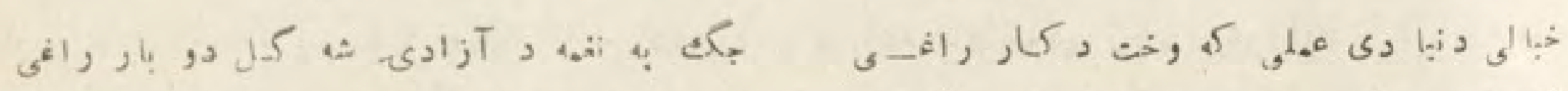

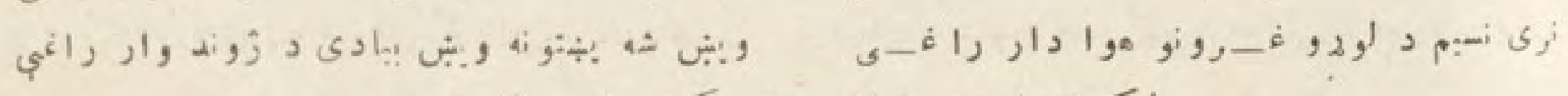

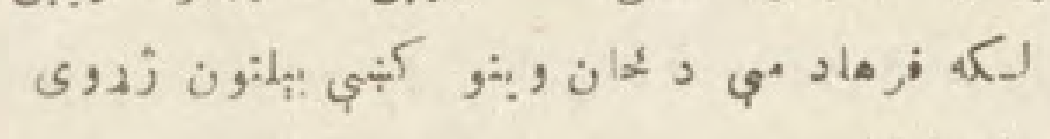


(1£)

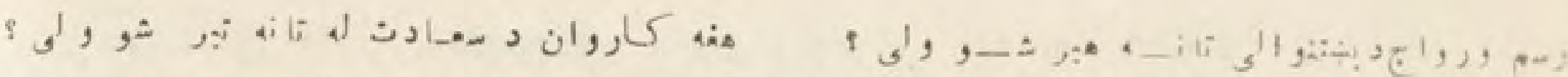

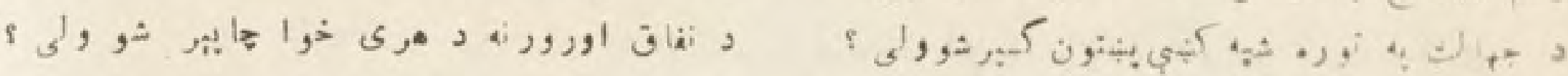
ى

4, و

Aا

4i

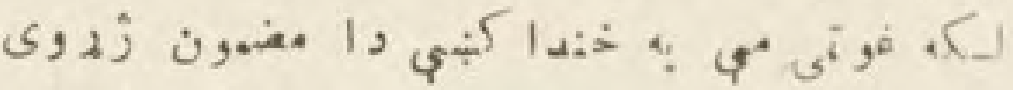

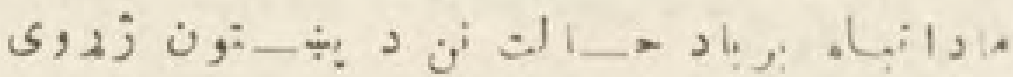

لى

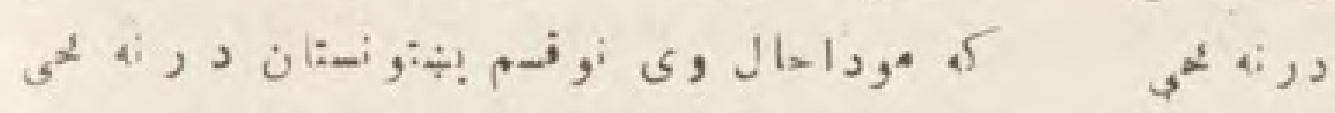

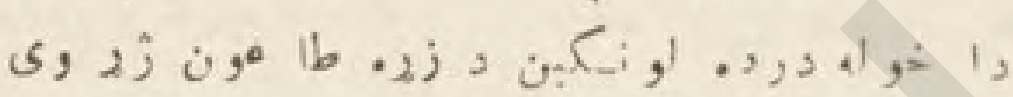

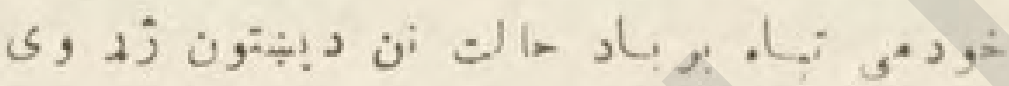

r X lo

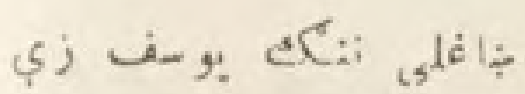

ئ $1: 30.4$

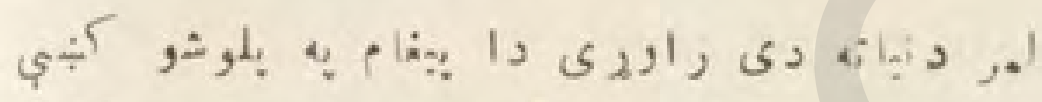

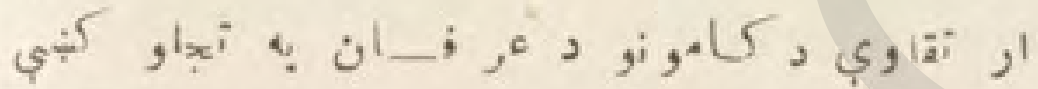

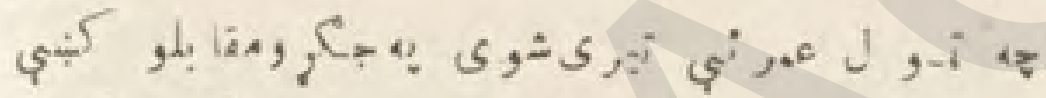

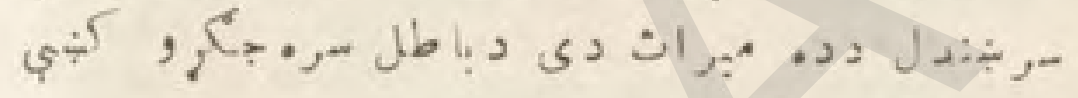

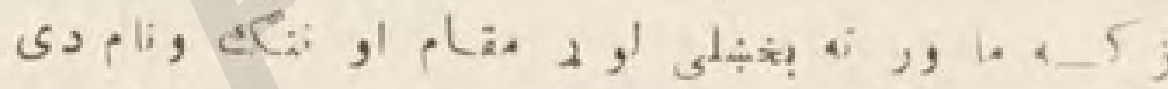

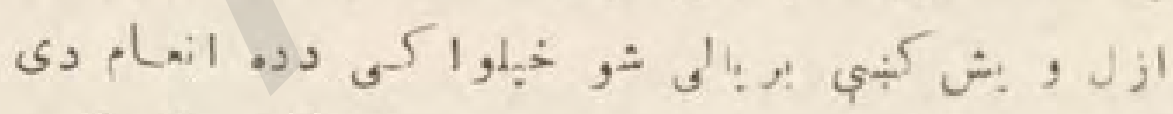

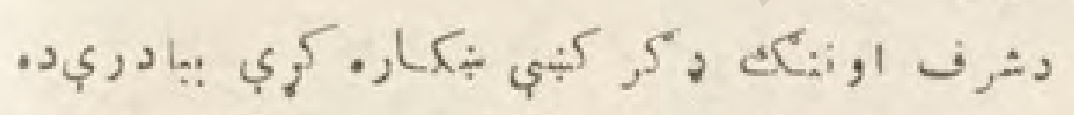

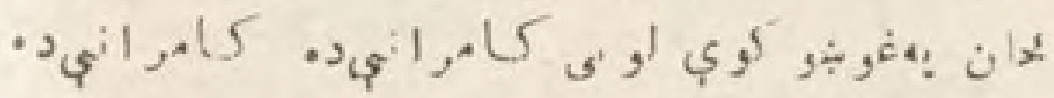

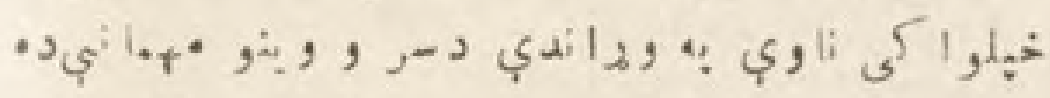

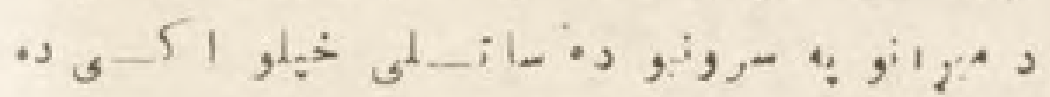

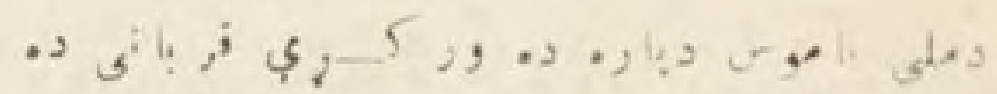

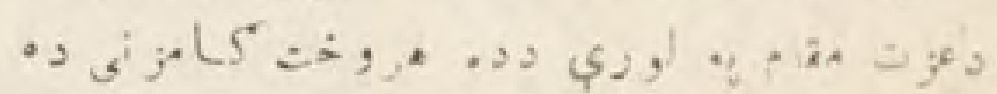
.

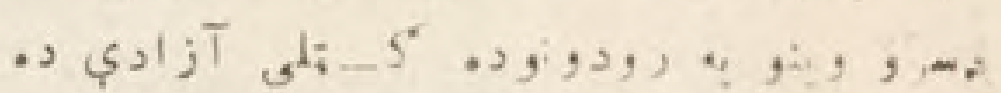

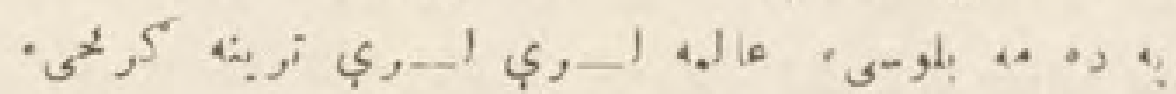

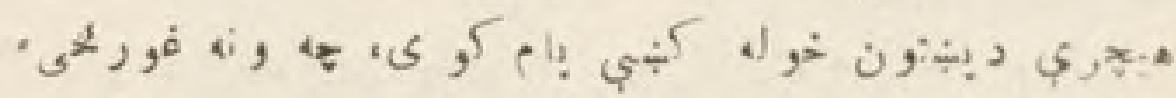

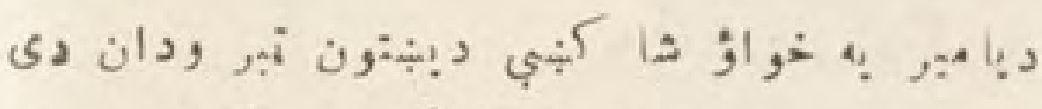

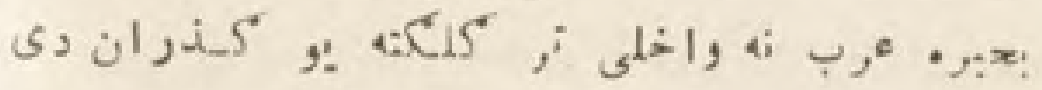

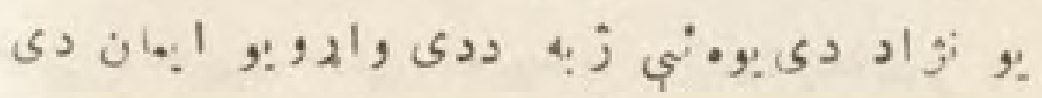

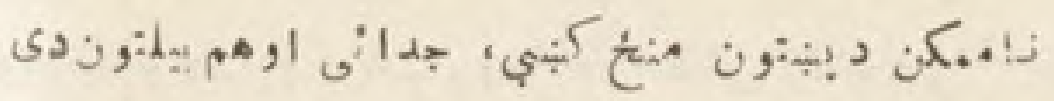

دامربن

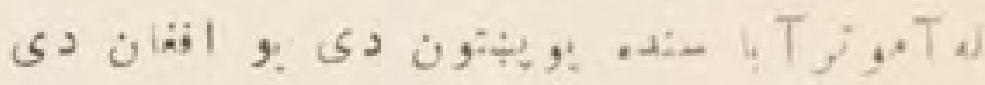

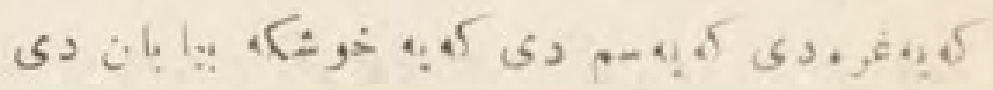

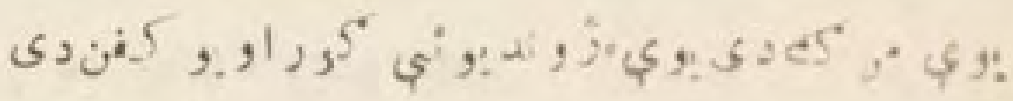

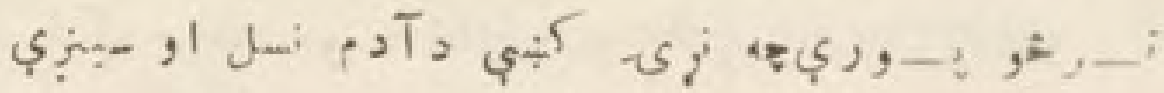

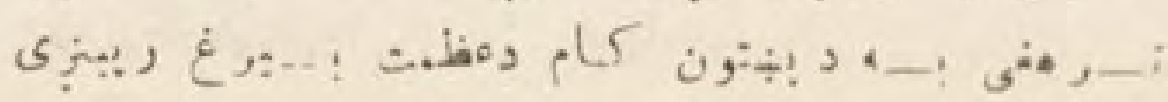




\section{أن}

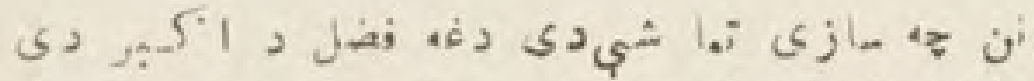

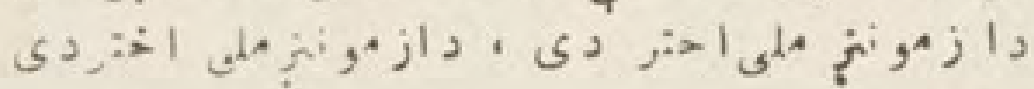

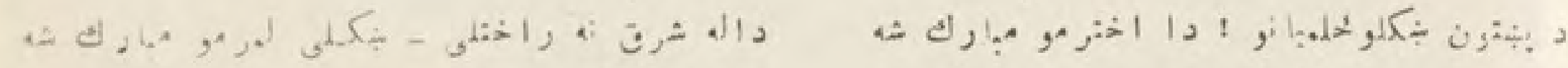

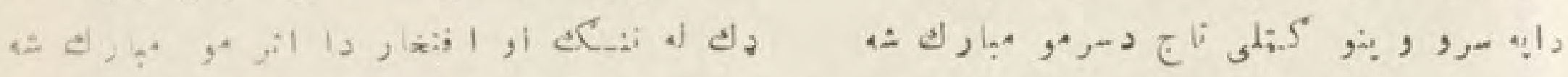

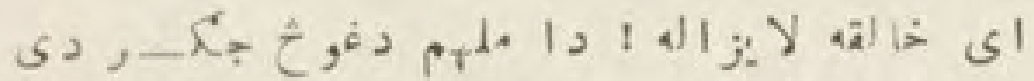

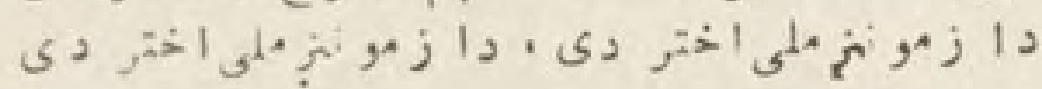

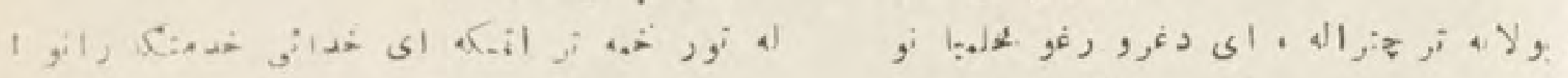

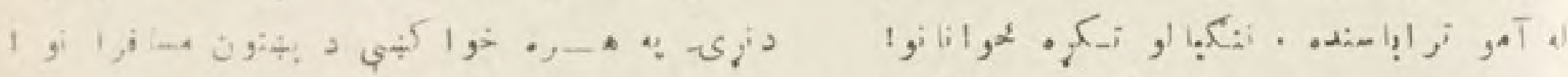

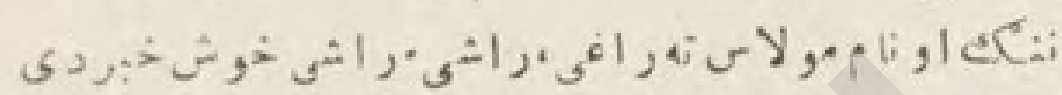

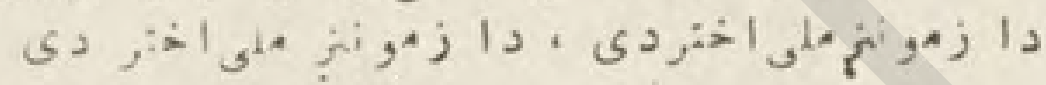

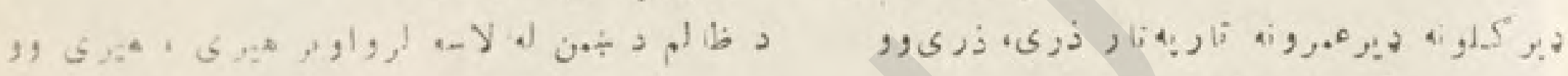

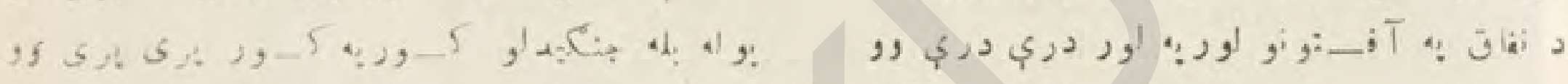

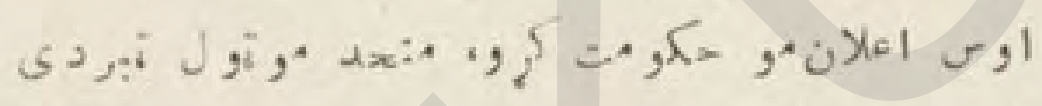

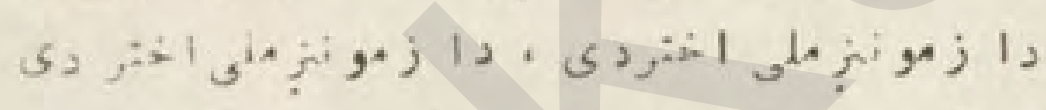

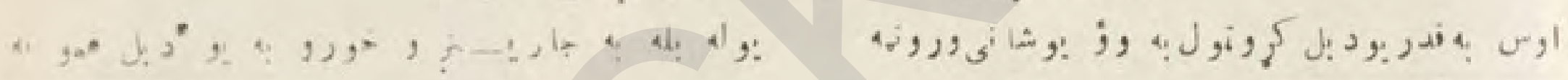

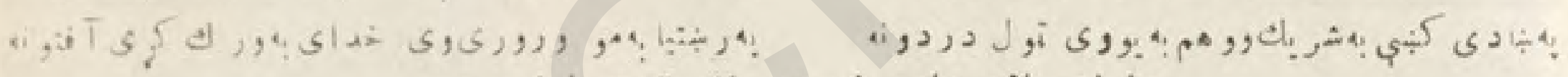

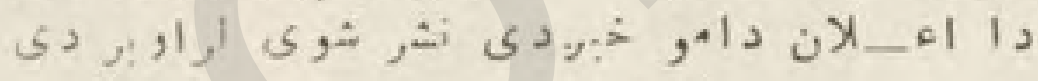

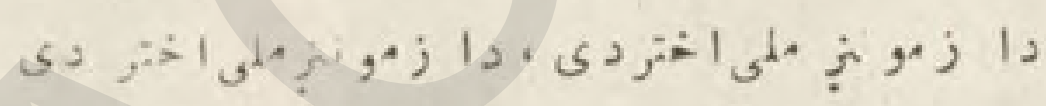

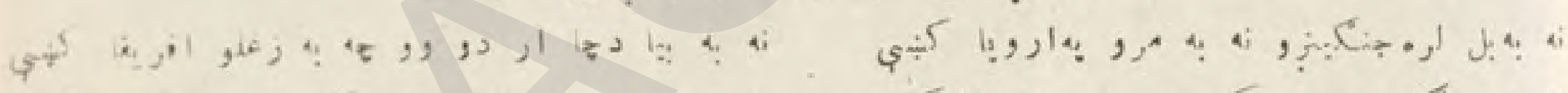

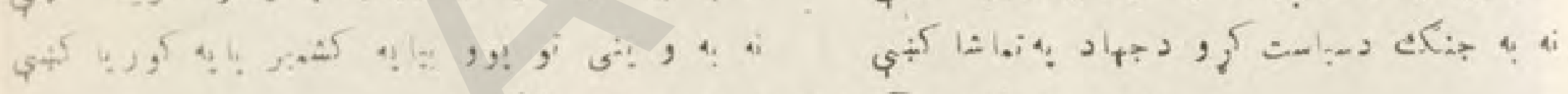

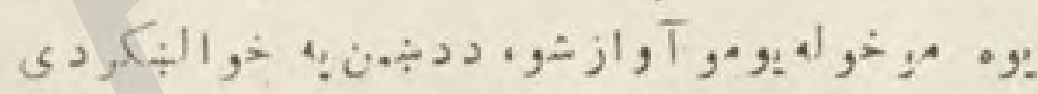

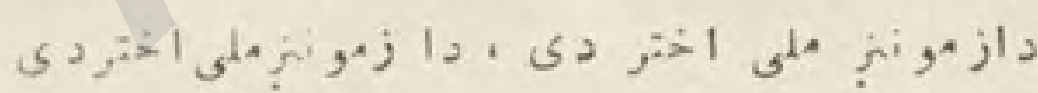

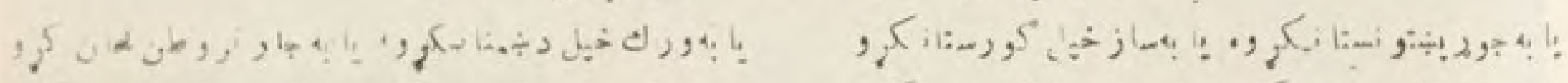

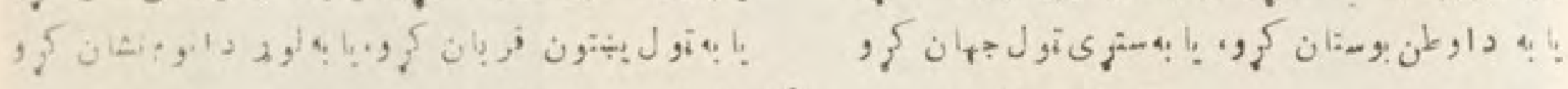

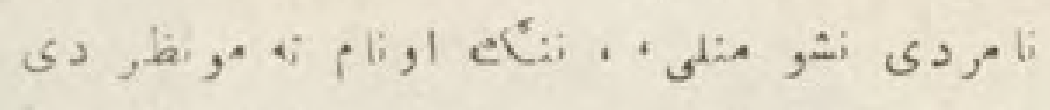
ى

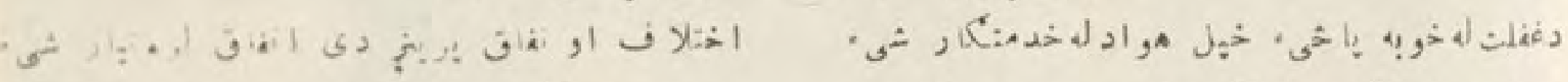

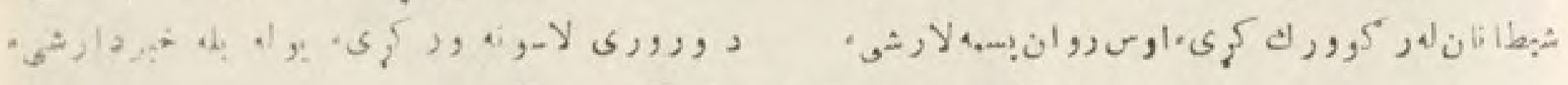

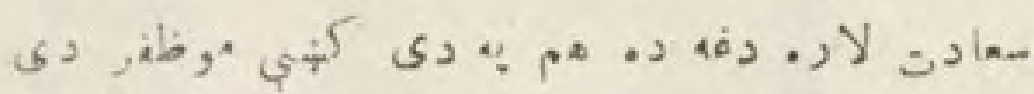

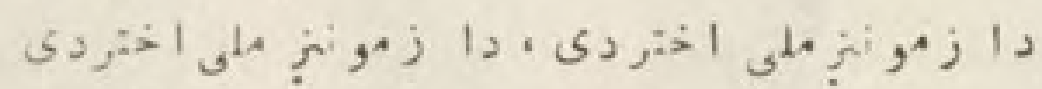

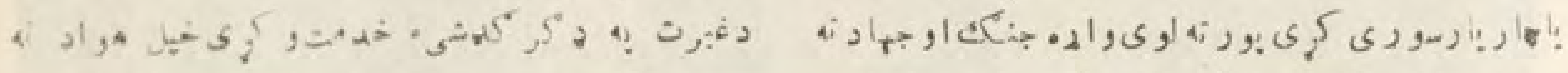

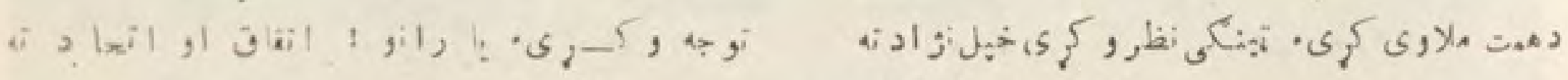

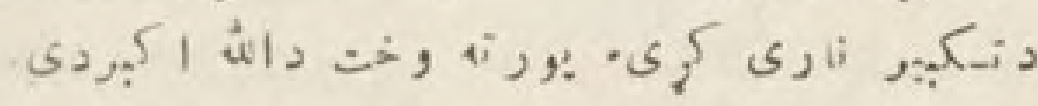

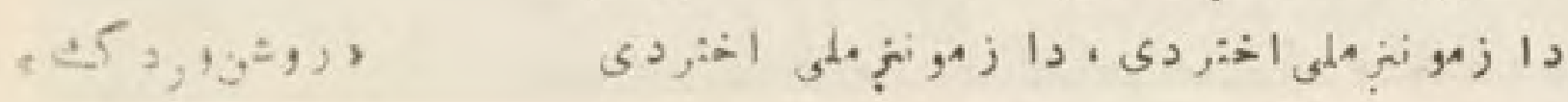


(17)

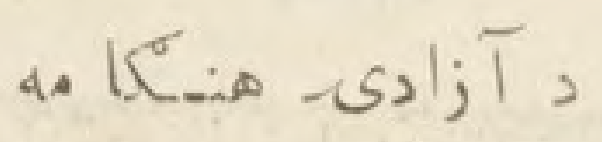

$$
\begin{aligned}
& \text { 2 } \\
& \text { 2 }
\end{aligned}
$$

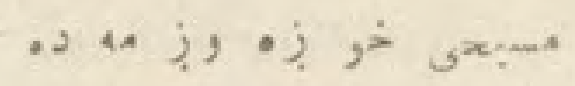

$$
\begin{aligned}
& \text { آ } \\
& \text { : : }
\end{aligned}
$$

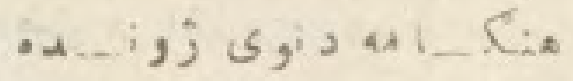

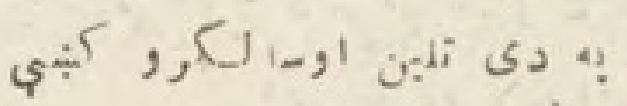

$$
\begin{aligned}
& \text { 20 }
\end{aligned}
$$

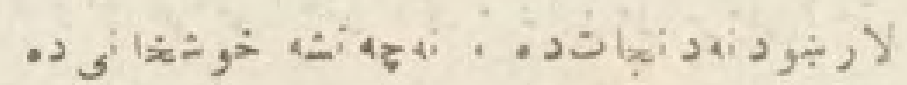

$$
\begin{aligned}
& \text { ن } \\
& \text { د }
\end{aligned}
$$

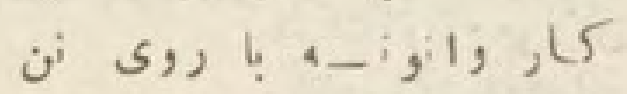

$$
\begin{aligned}
& \text { ن }
\end{aligned}
$$

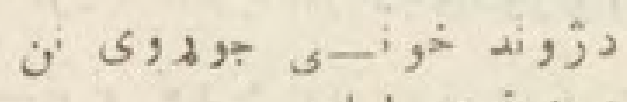

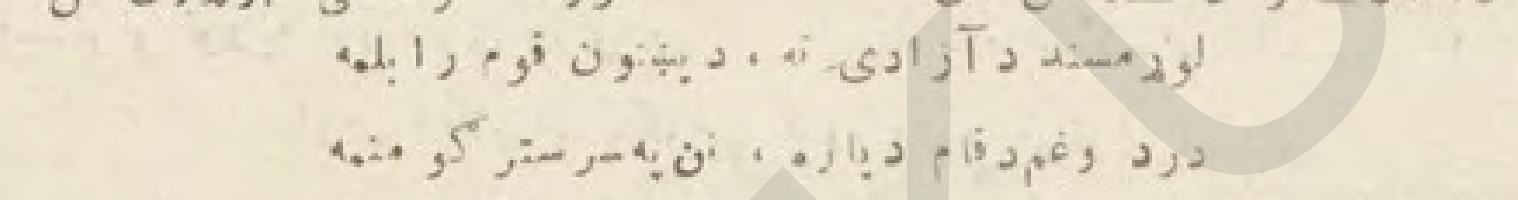

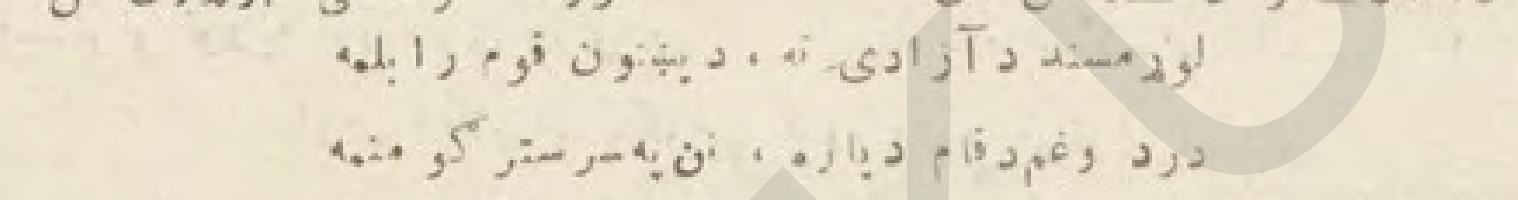

$$
\begin{aligned}
& \text { ى } \\
& \text { s } \\
& \text {.2. } \\
& \text { (2) }
\end{aligned}
$$

داد,

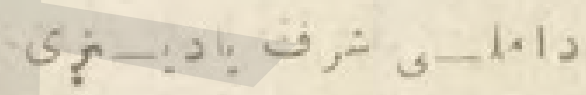

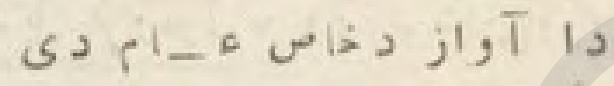

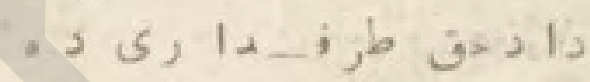

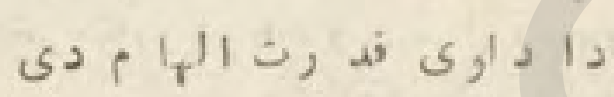
v 12 ज ها لو

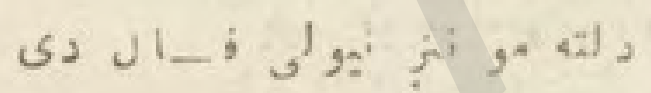

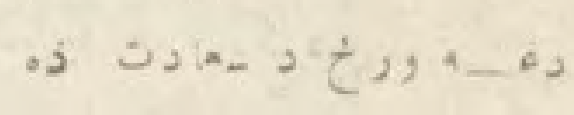
ى

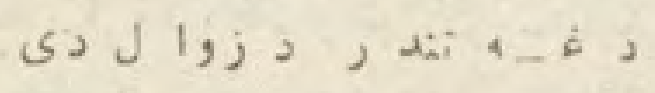
به دى

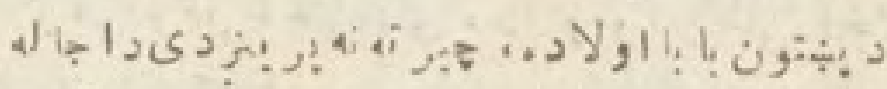

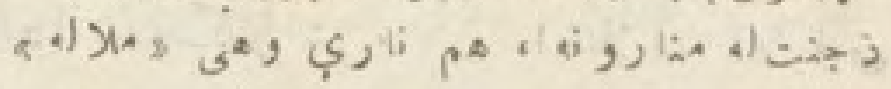

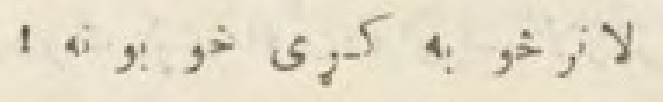

$$
\begin{aligned}
& \text { 4i , ز } \\
& \text { هi }
\end{aligned}
$$

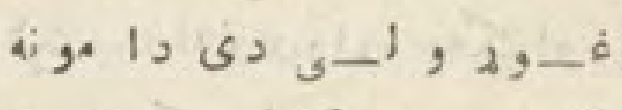

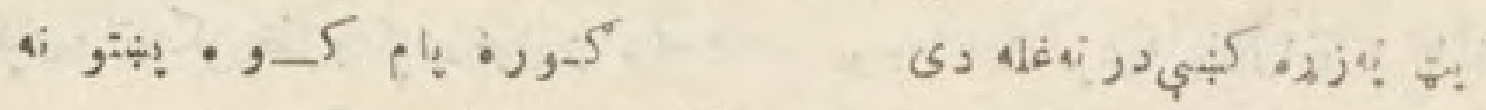

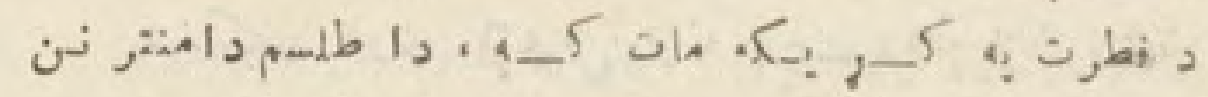

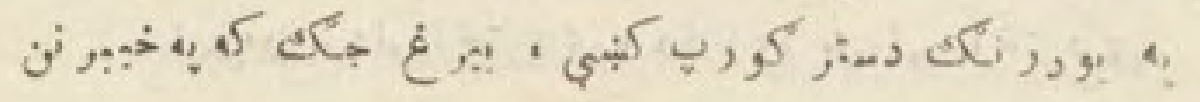

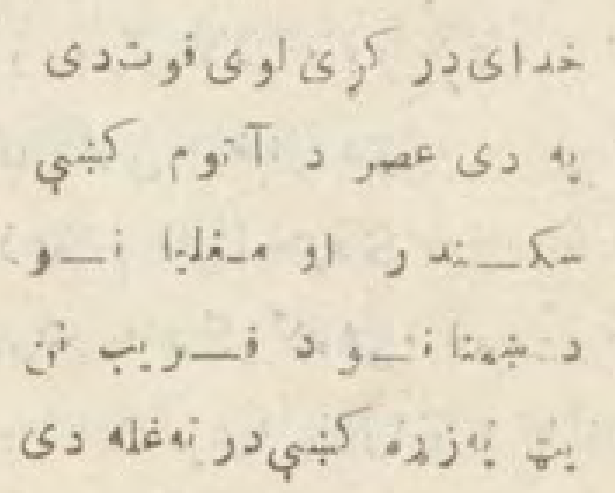




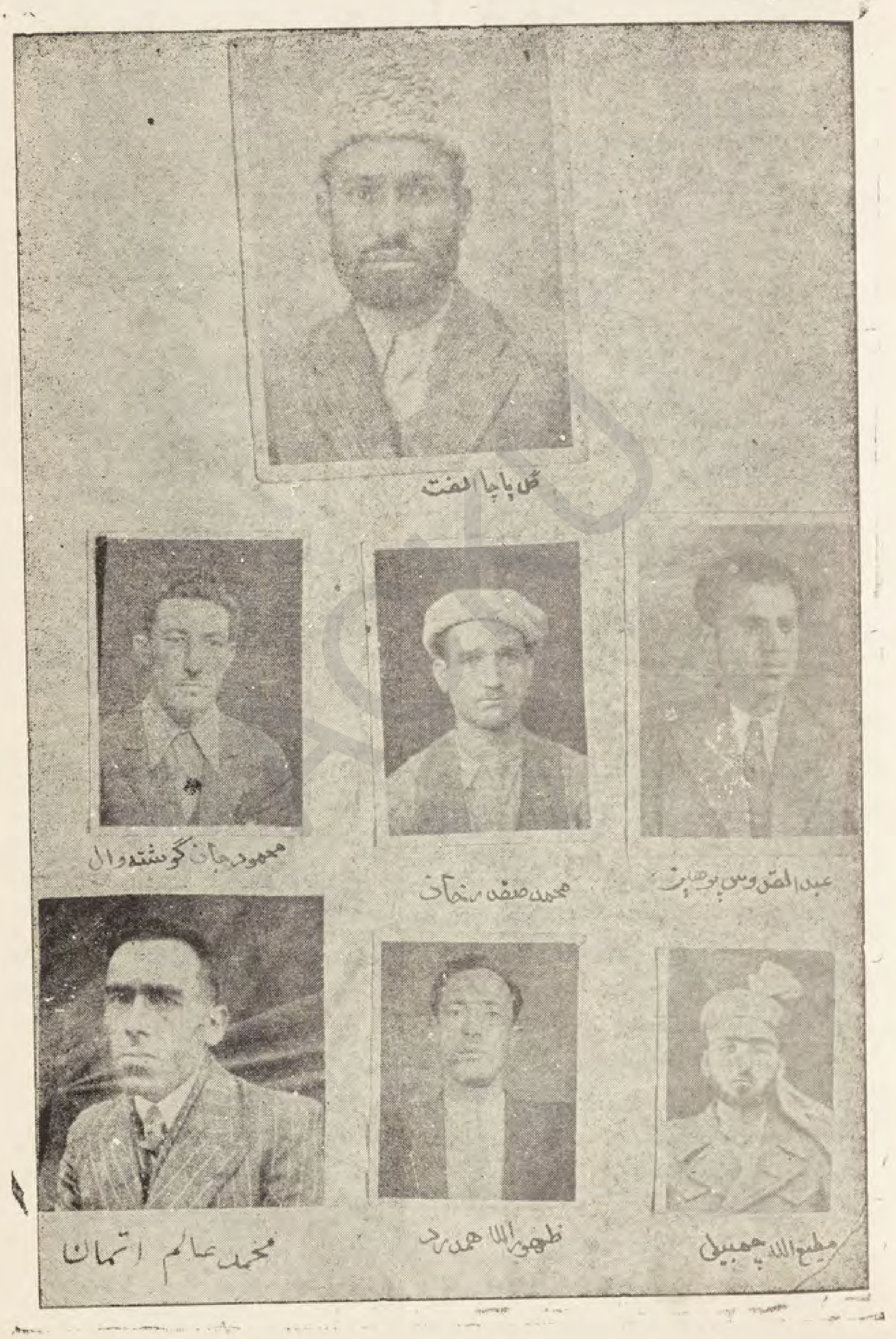




\section{£g}

ज

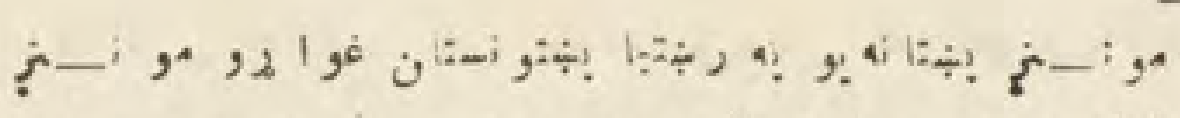

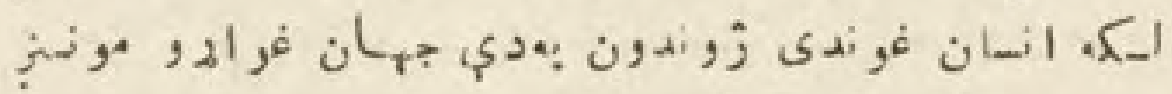

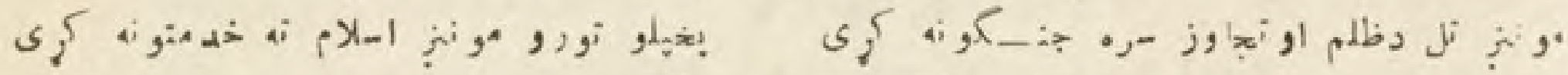

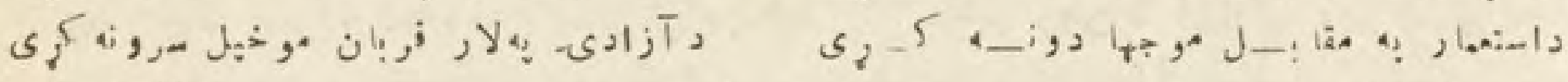
is

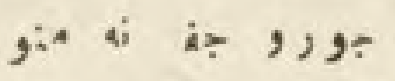

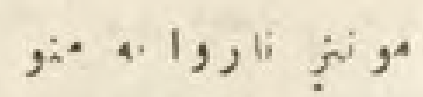

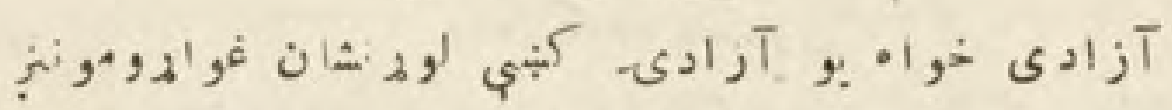

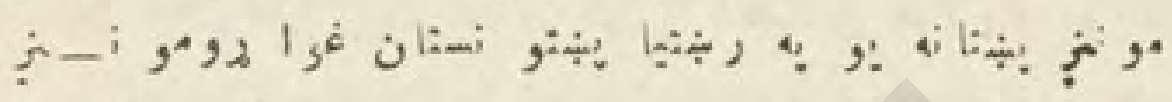

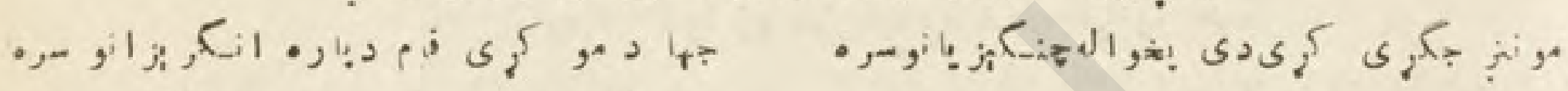

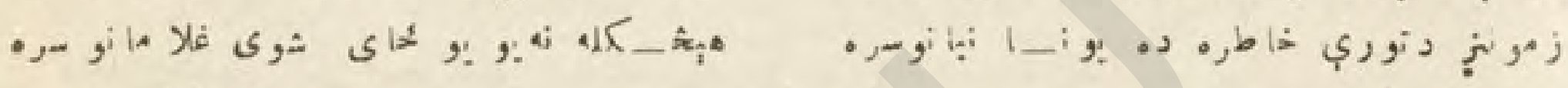

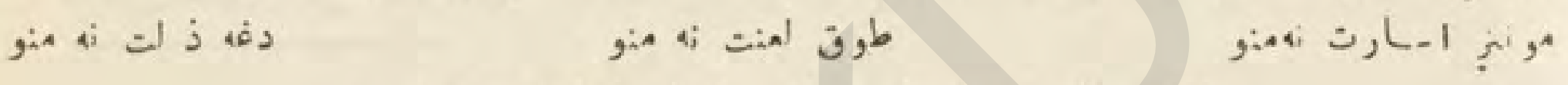

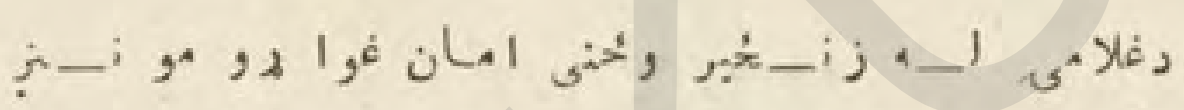

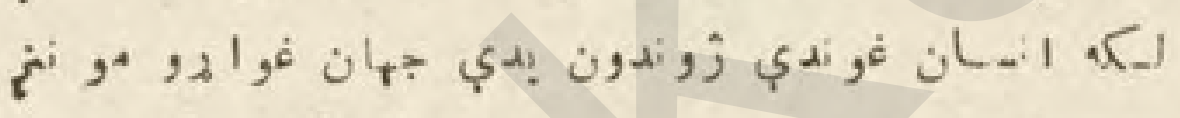

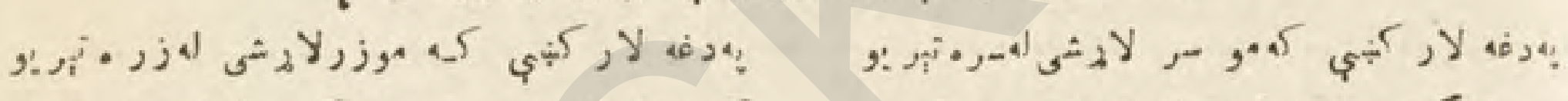

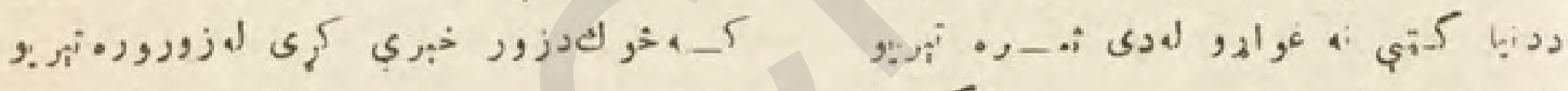

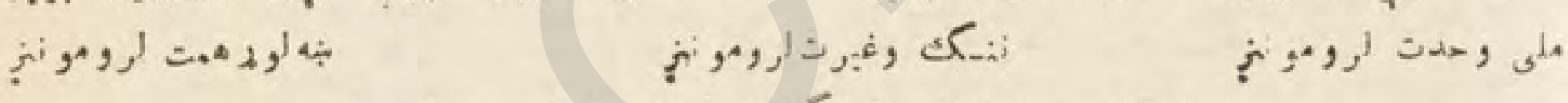

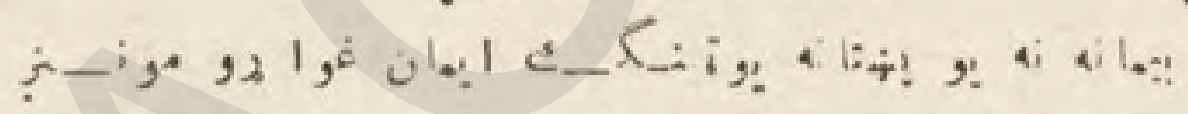

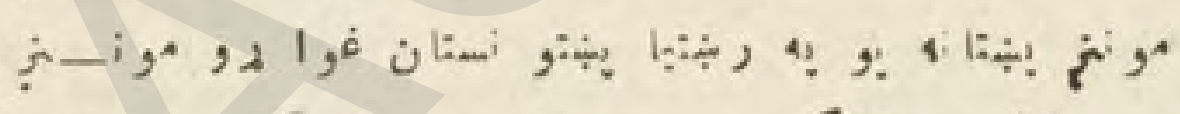

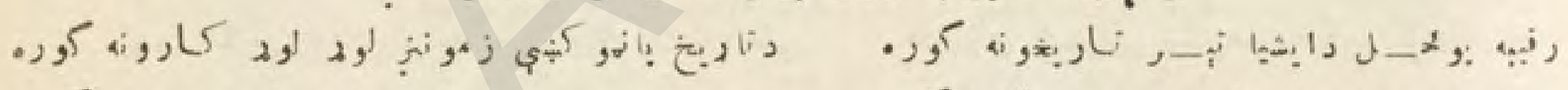

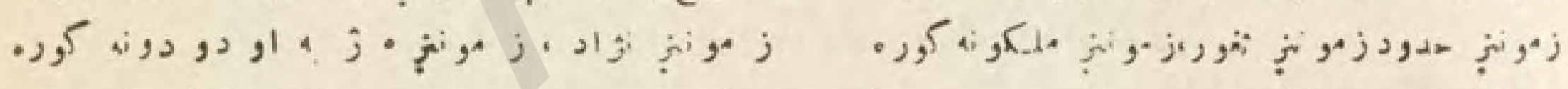

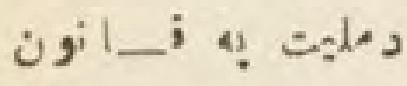
دط:

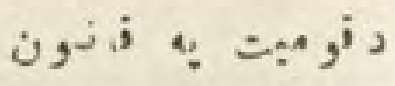

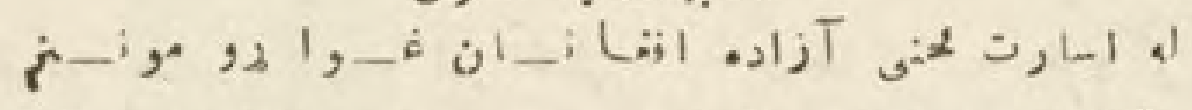

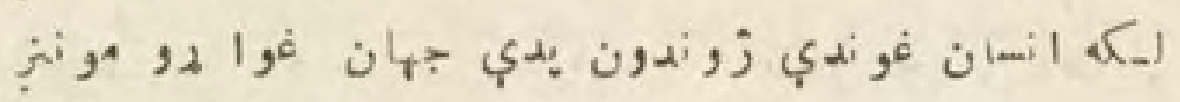

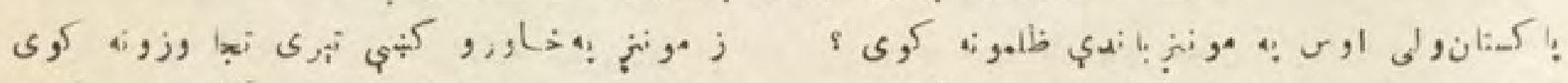

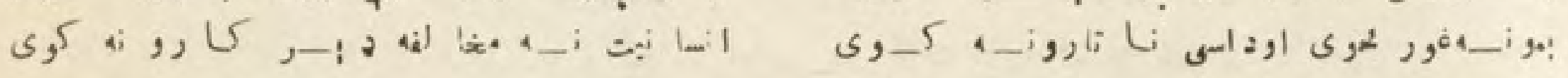
ن
ن i i, is

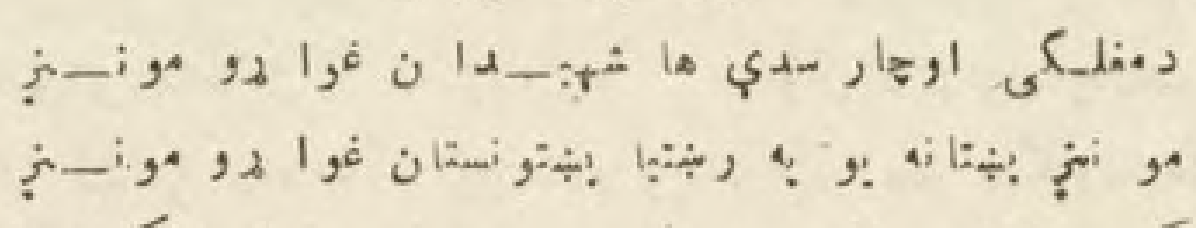

ن

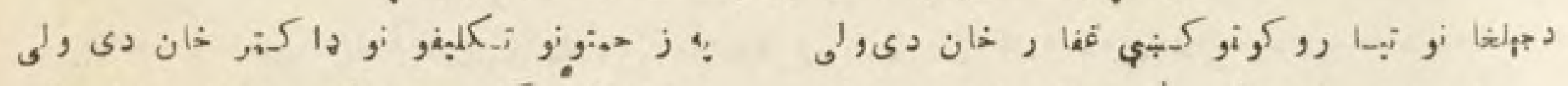

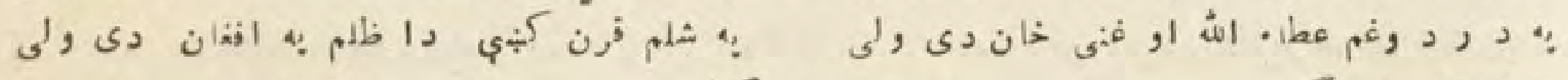

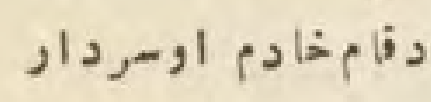

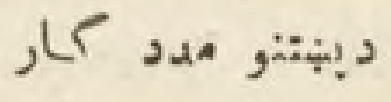

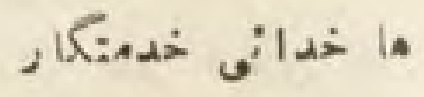

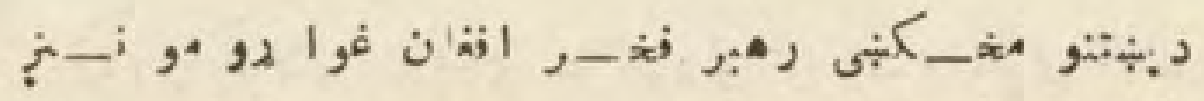

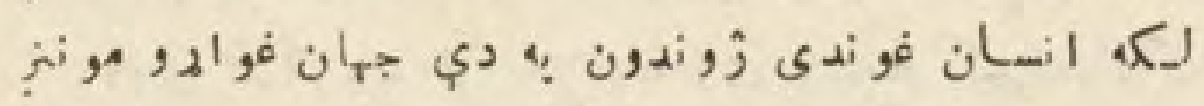


(11)

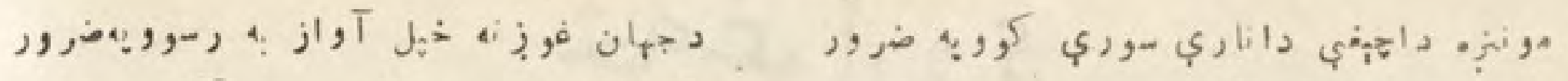

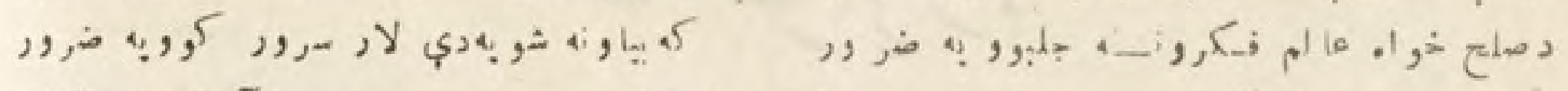

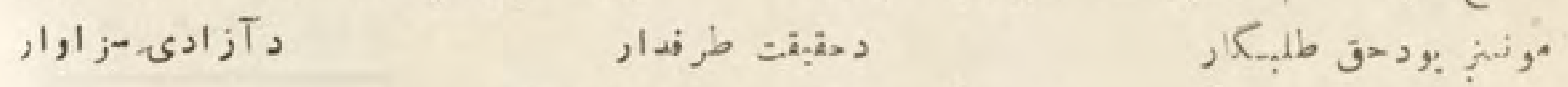

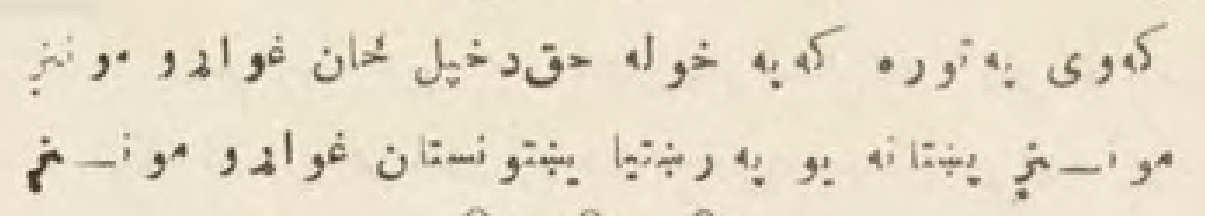

(2) 9

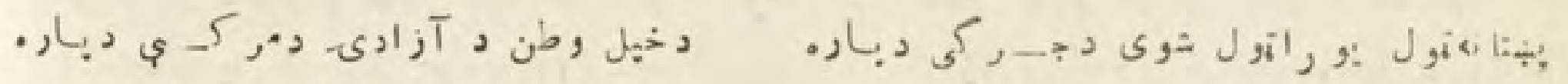

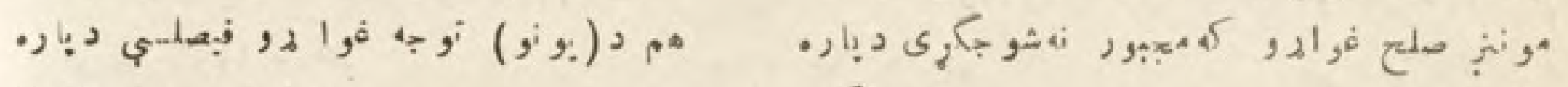

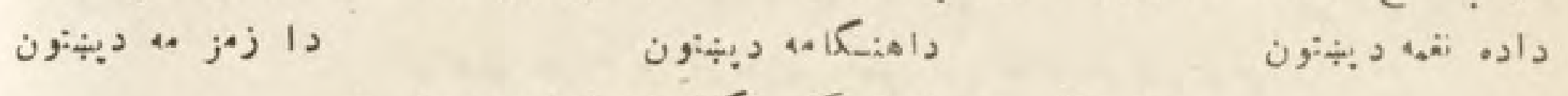

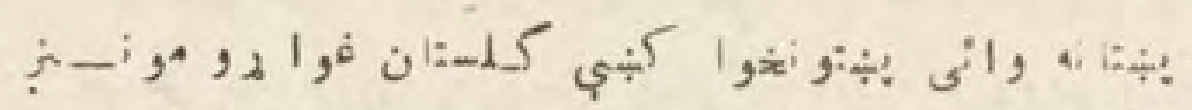

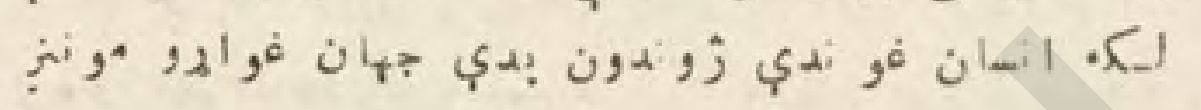

הa

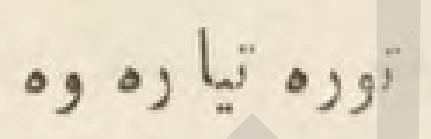

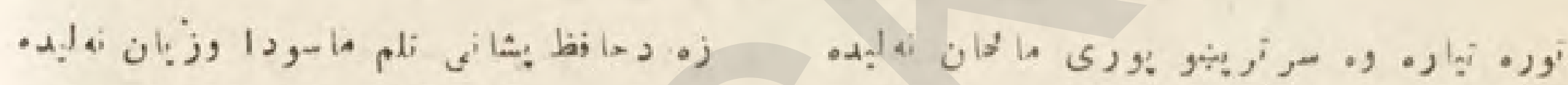

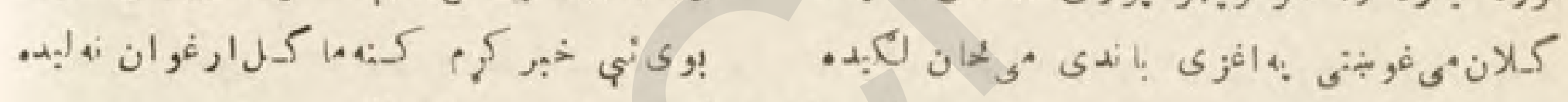

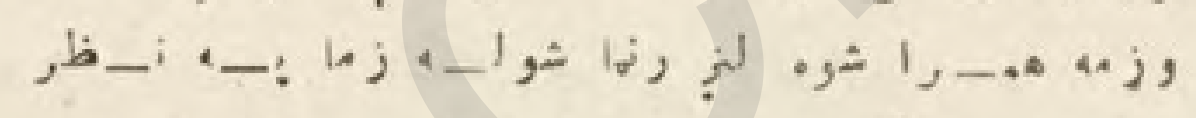

- : : :

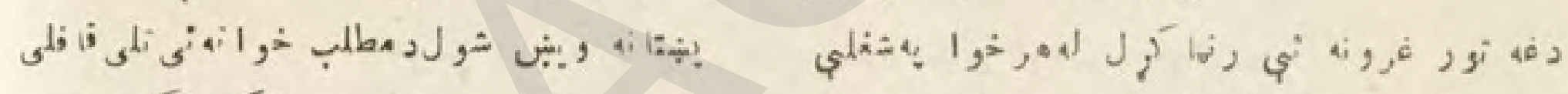

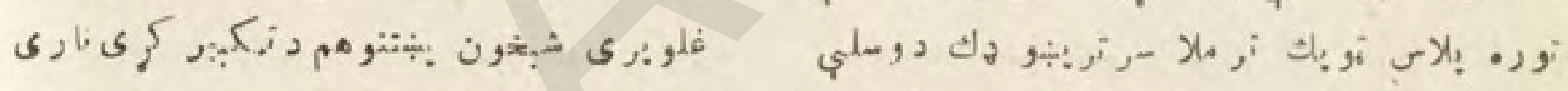

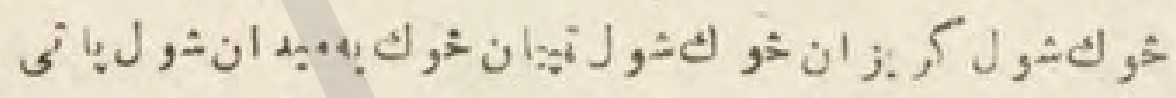

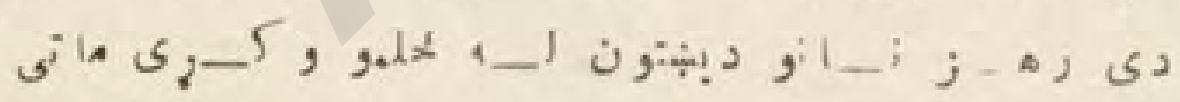

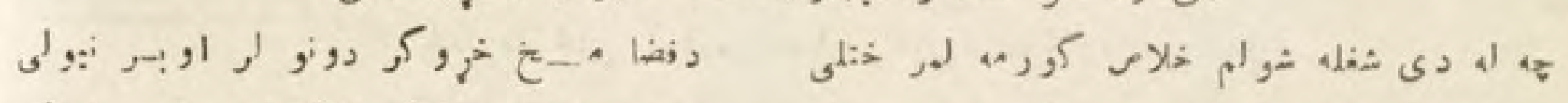

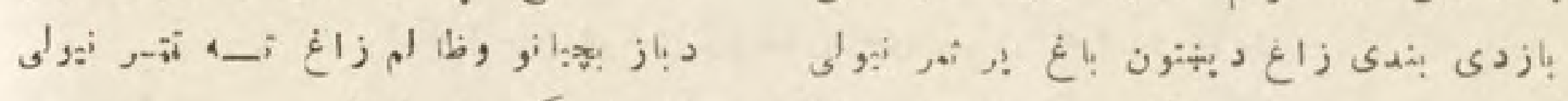

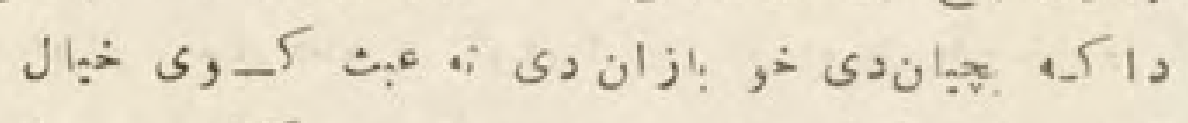

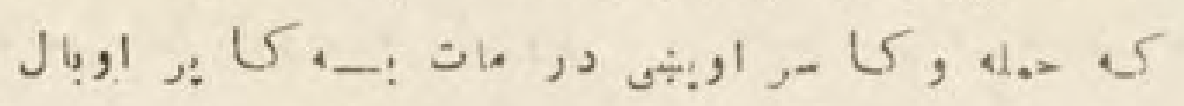

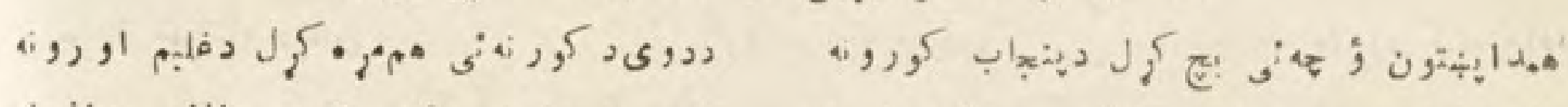

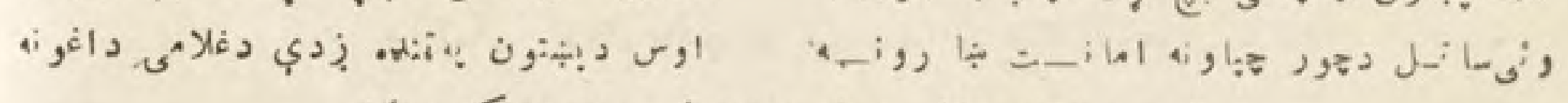

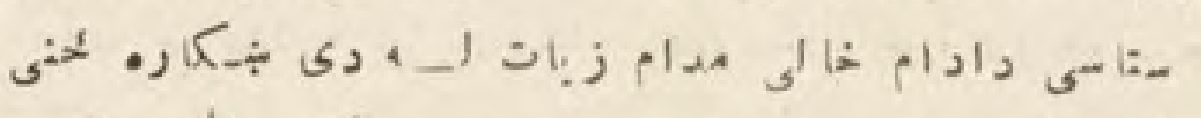
ا

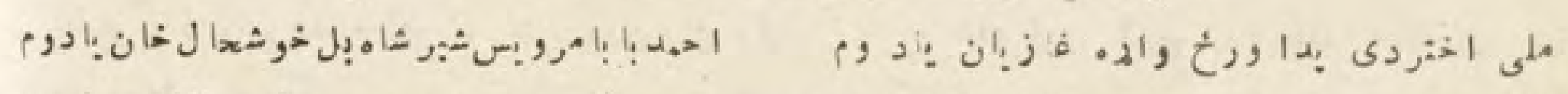

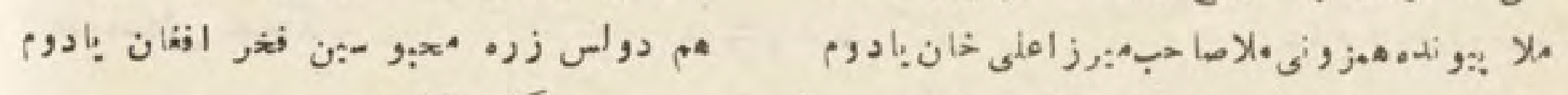

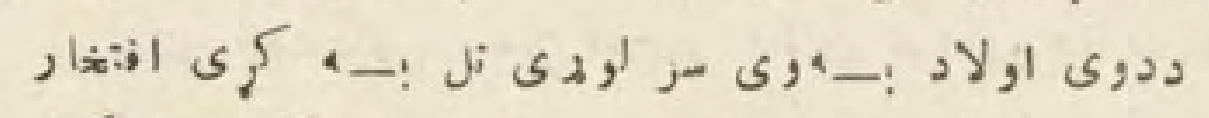
 


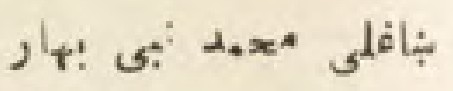

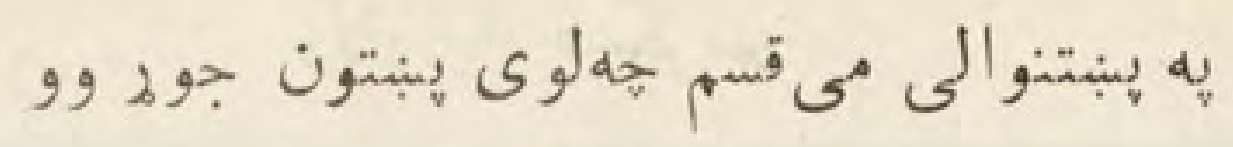

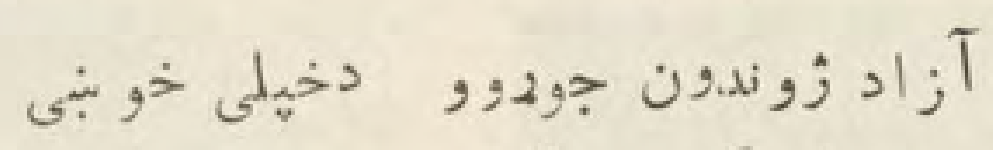

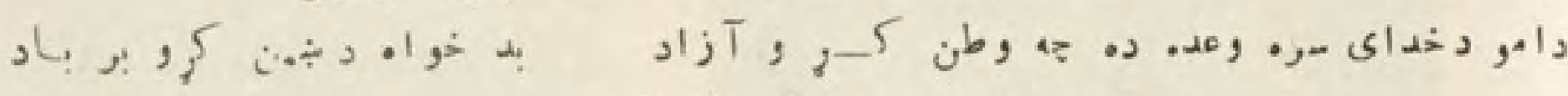

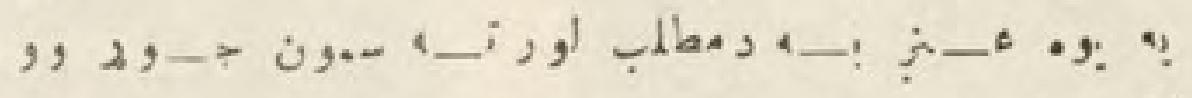

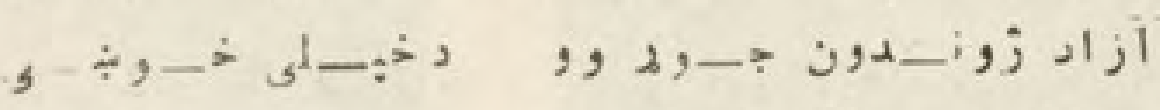

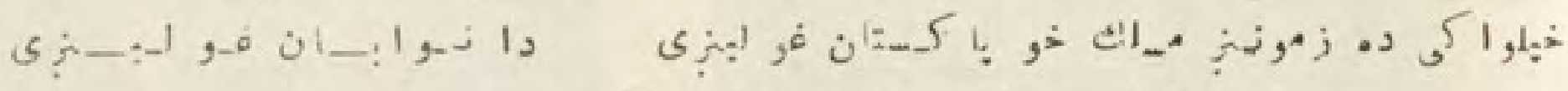

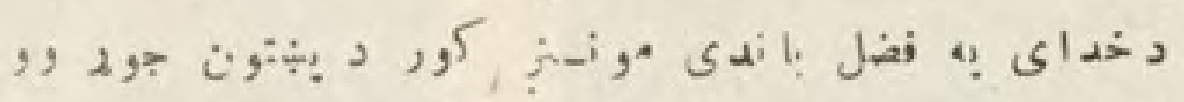

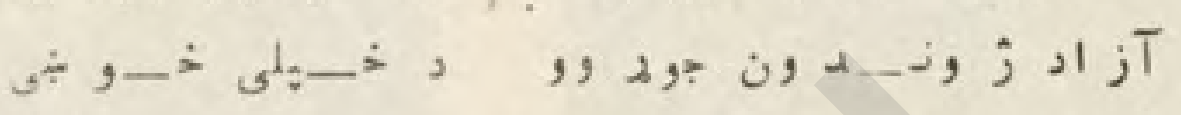

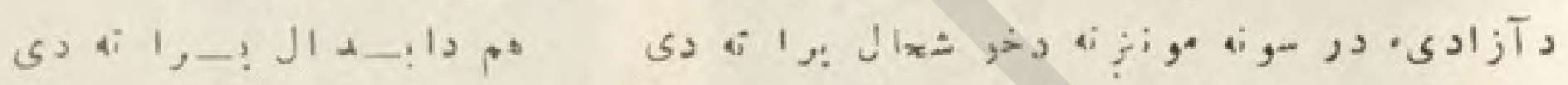

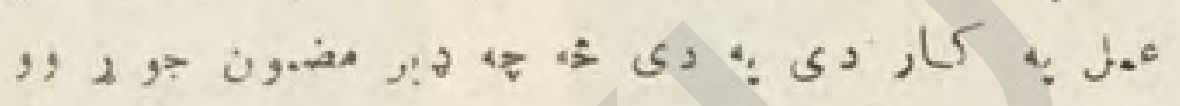

آ آراد زو,

د,

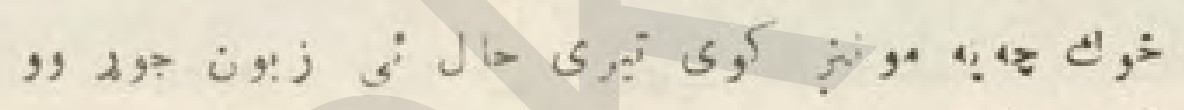

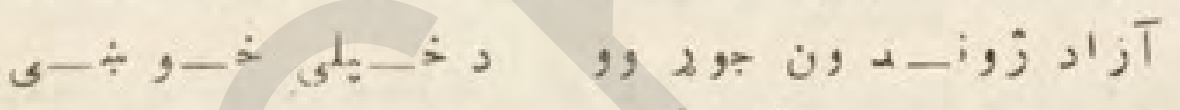

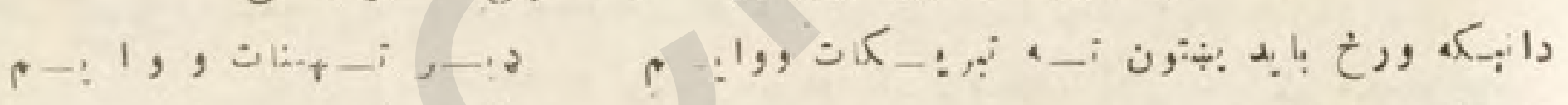

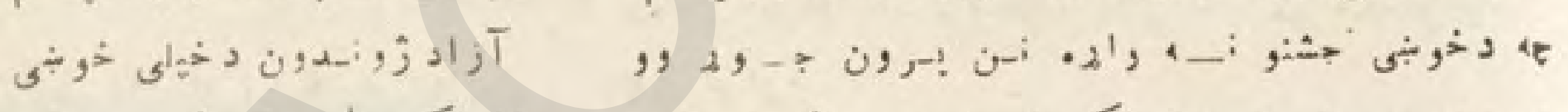

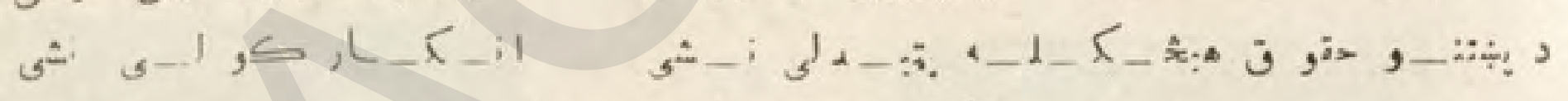

,

آ آزاد

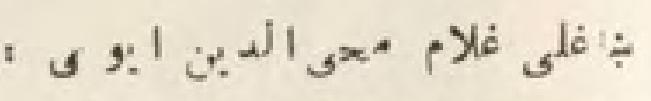

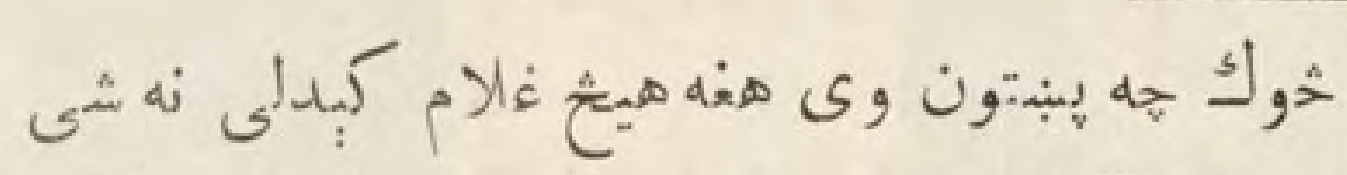

كه ن

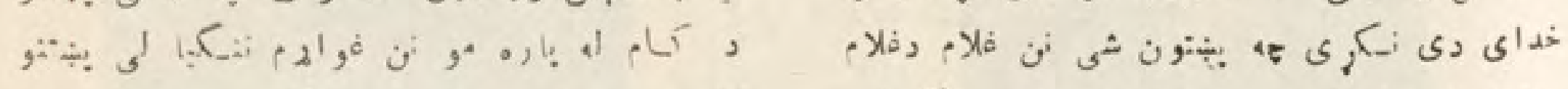

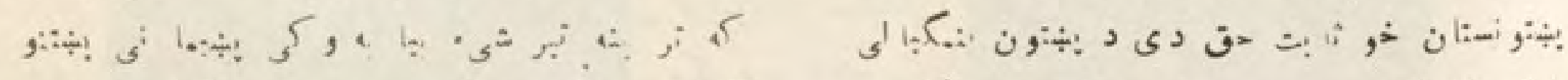

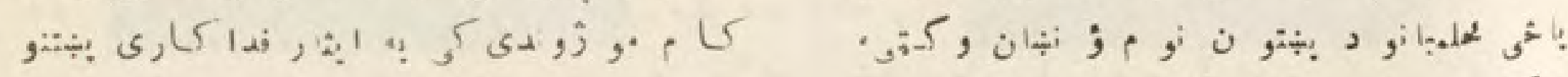

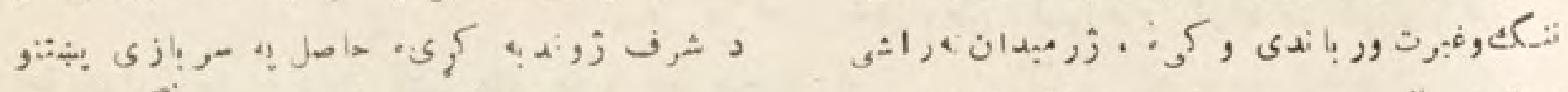

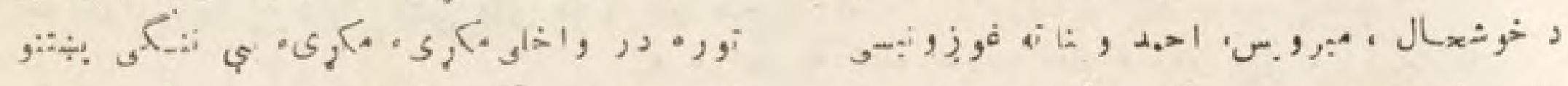

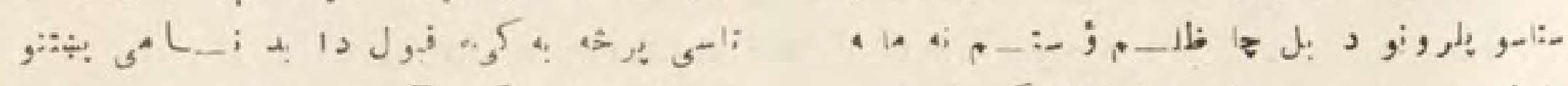

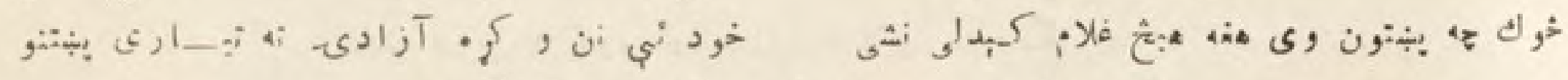

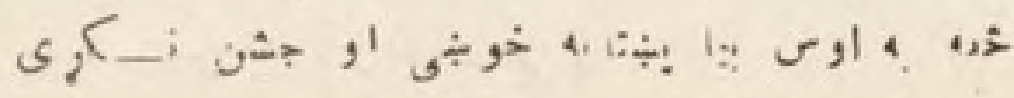

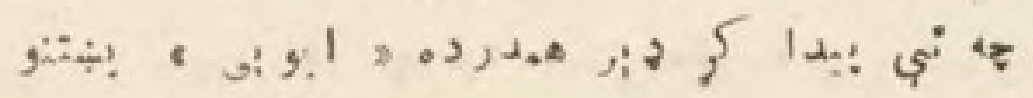




\section{ولام تيار عسك,}

4.

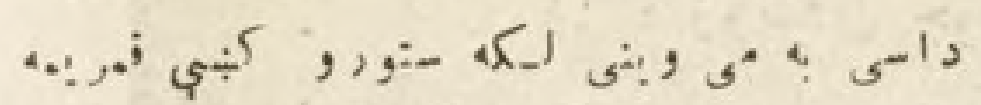

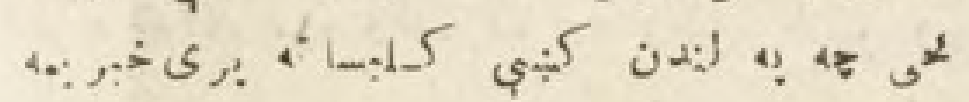

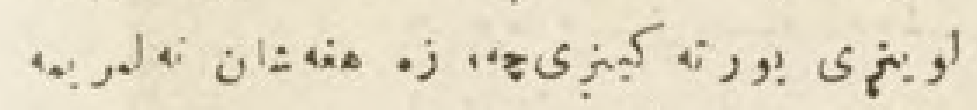

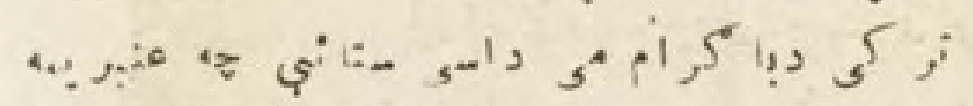

4.

با

?

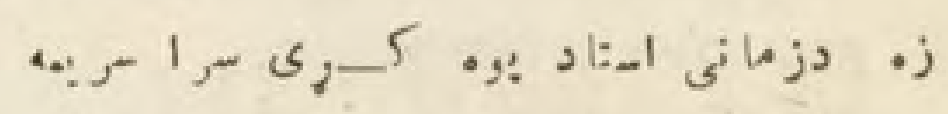

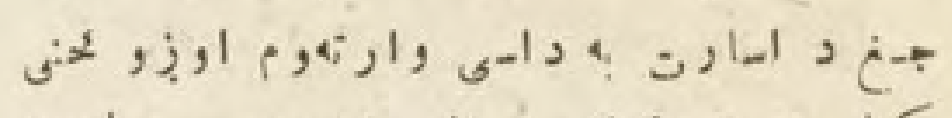

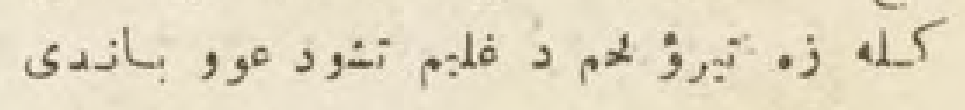

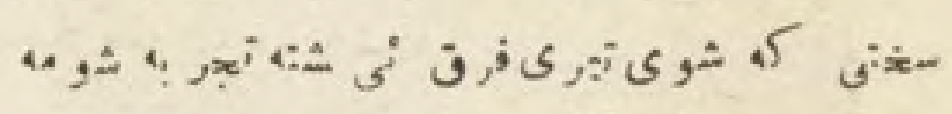

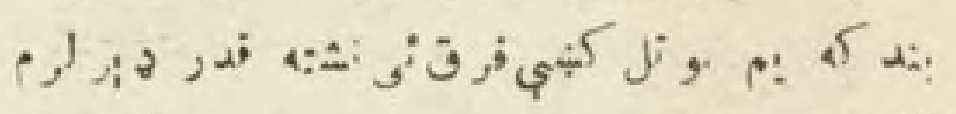

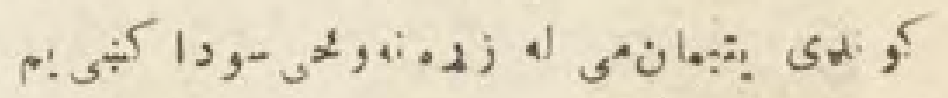

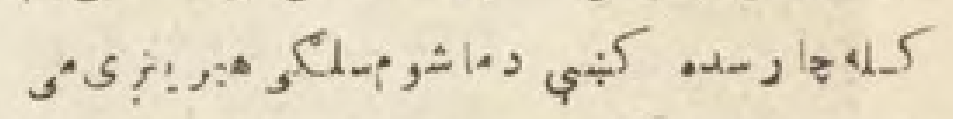
دان :

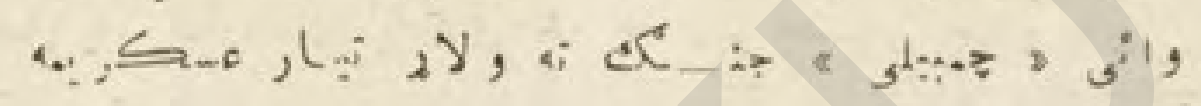

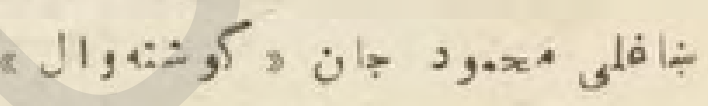

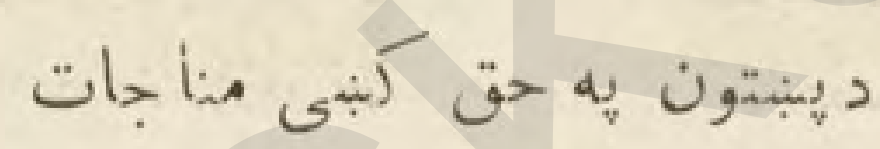

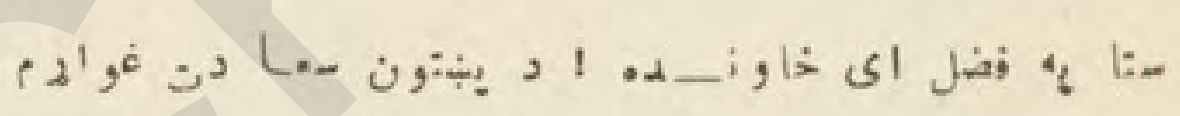
:

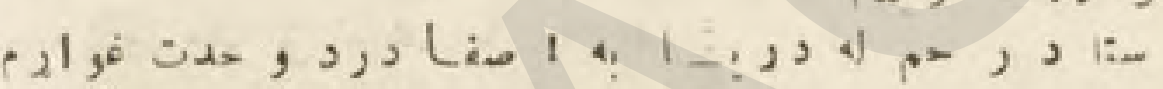

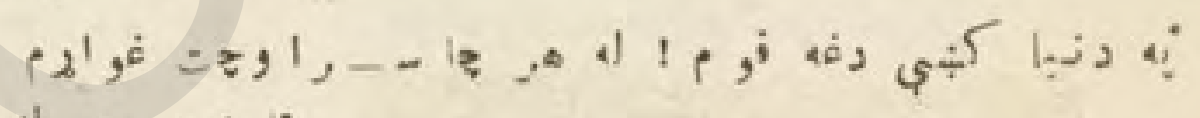

$$
\begin{aligned}
& \text { ل }
\end{aligned}
$$

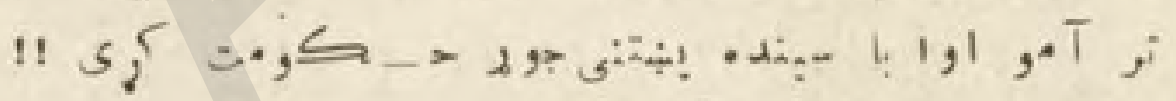

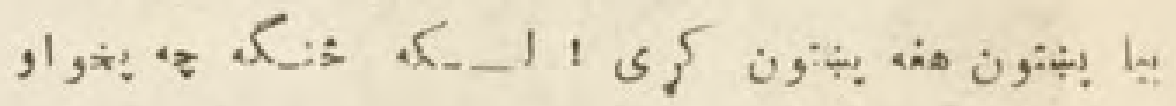

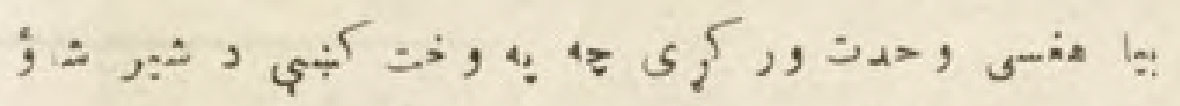

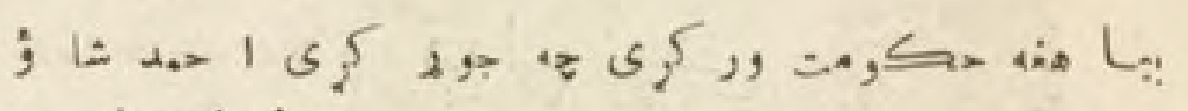

ها:

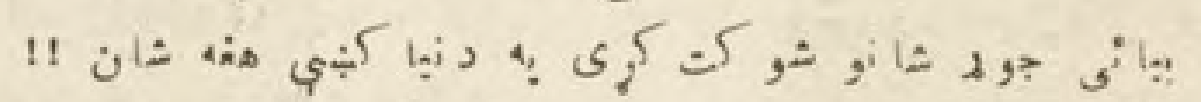

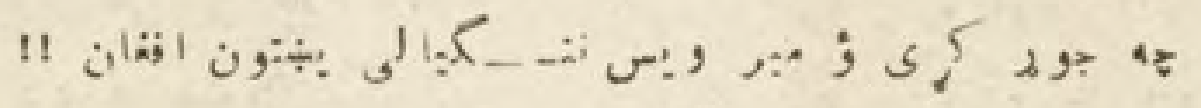

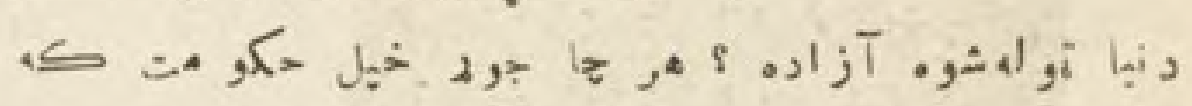

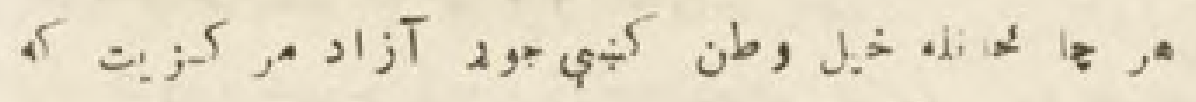$$
\text { هر ها }
$$

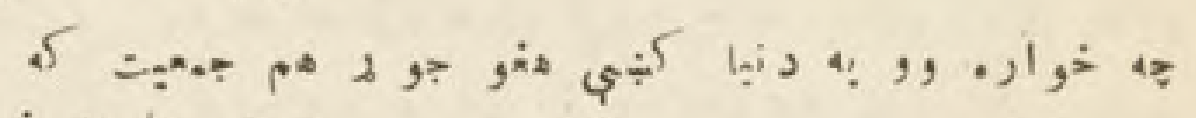

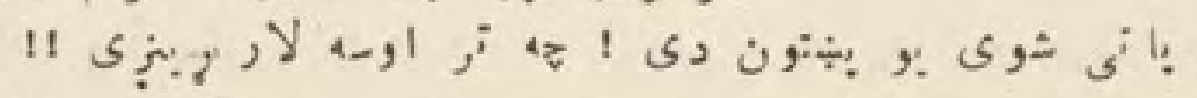

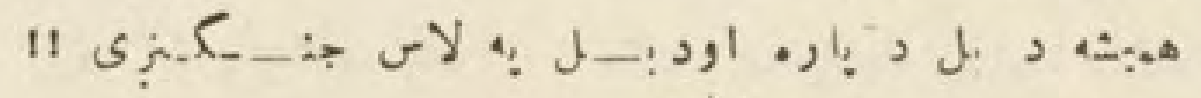

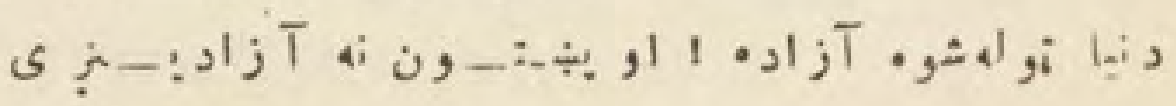

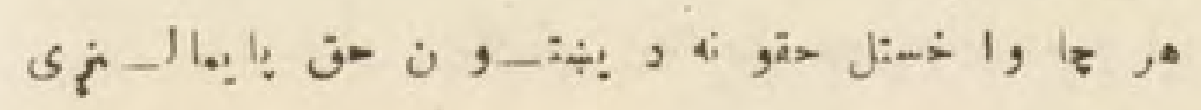




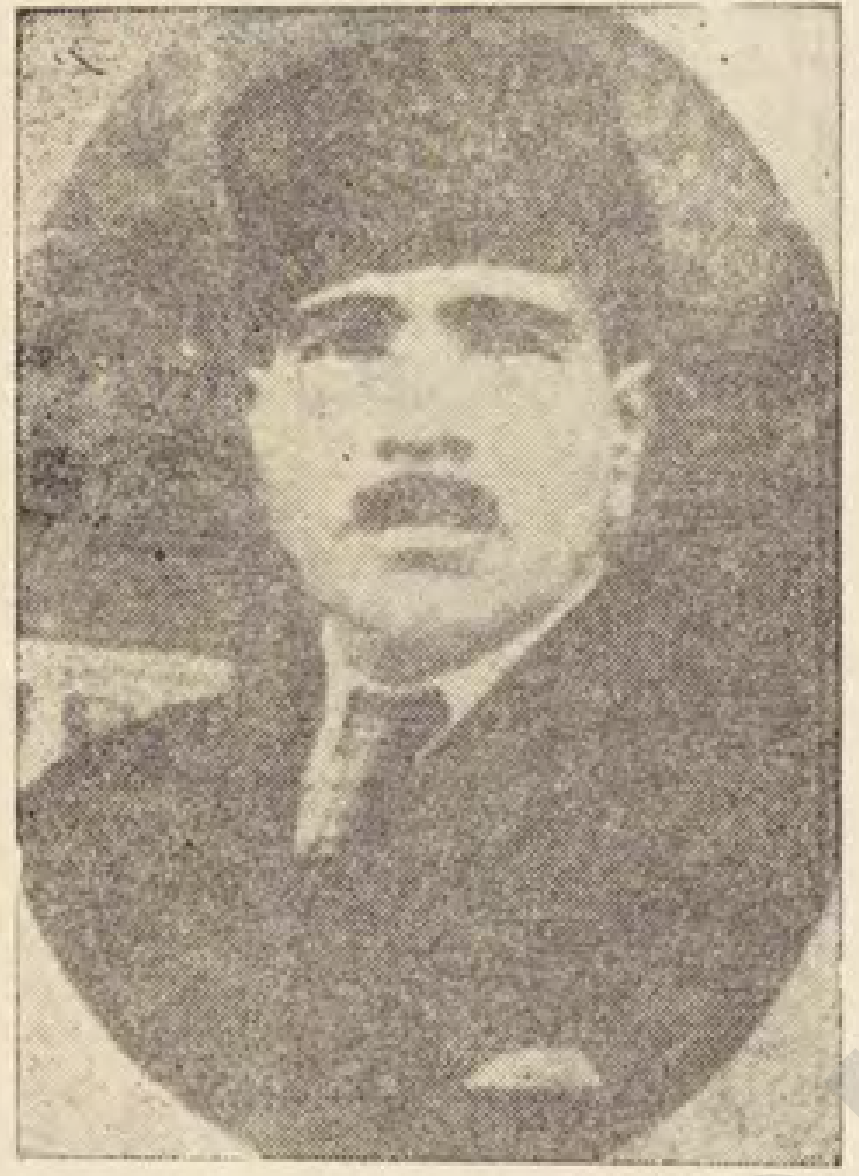

$$
\text { - }
$$

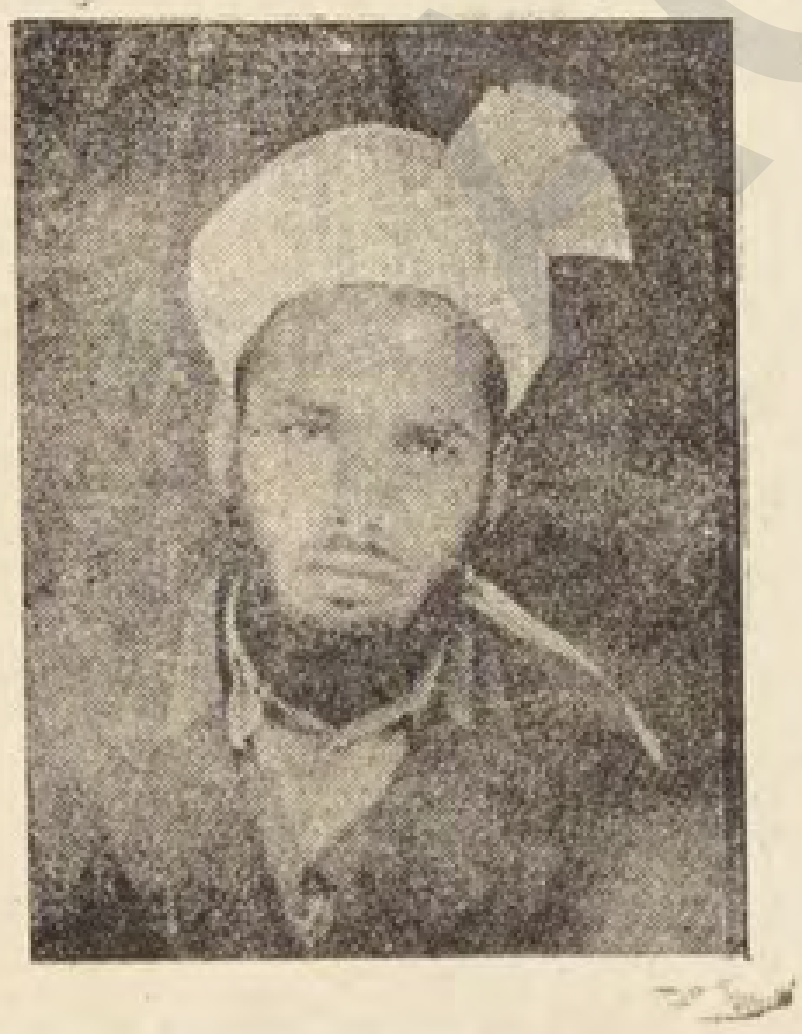

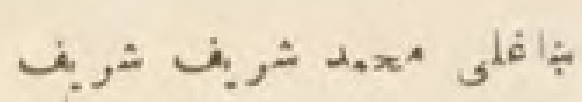

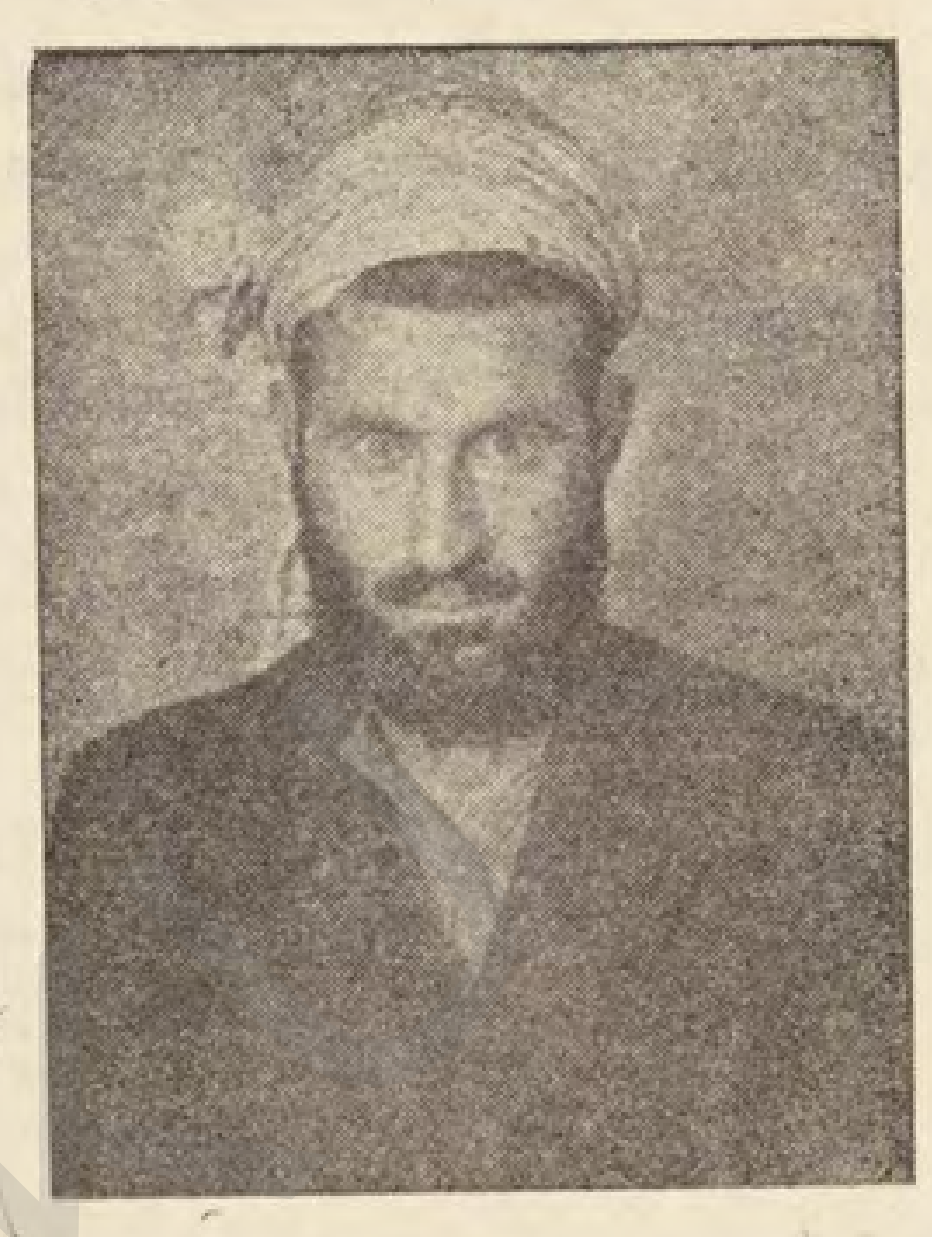

بخاغٔلى

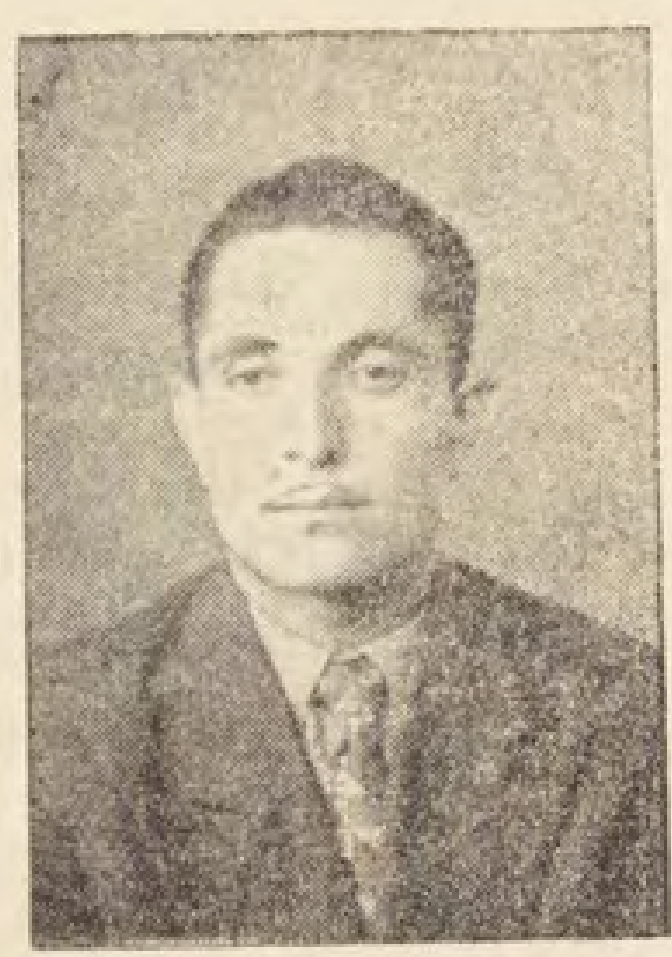

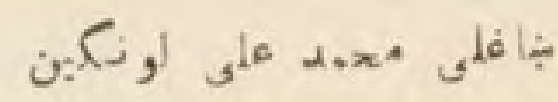




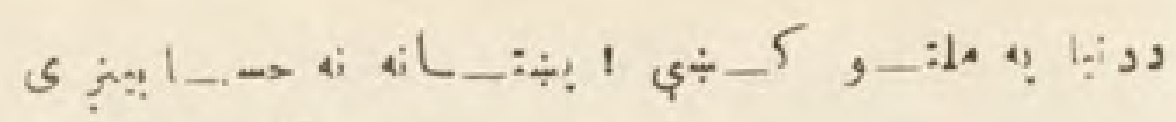

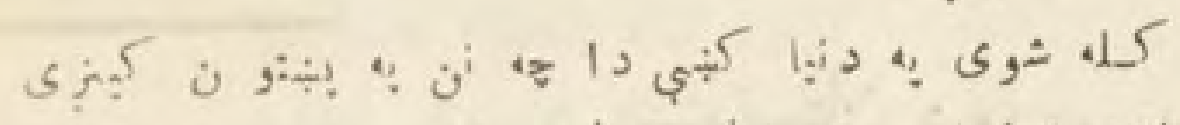

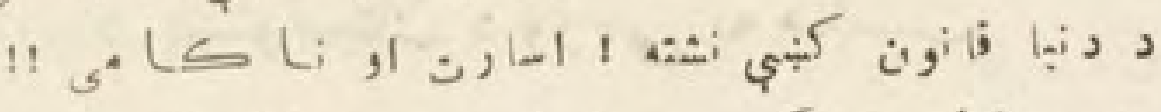

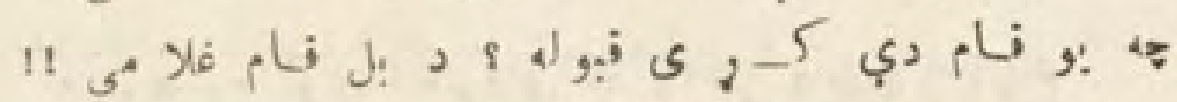

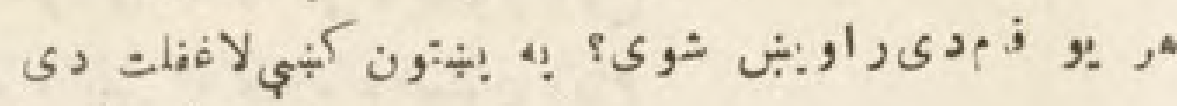

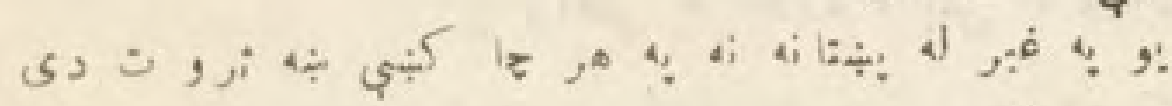

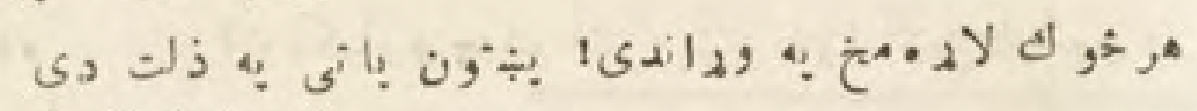

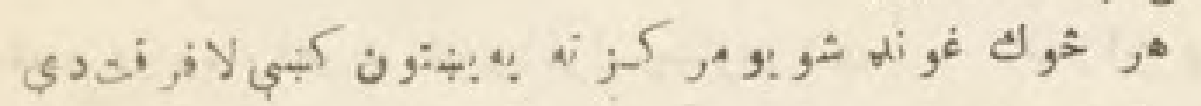

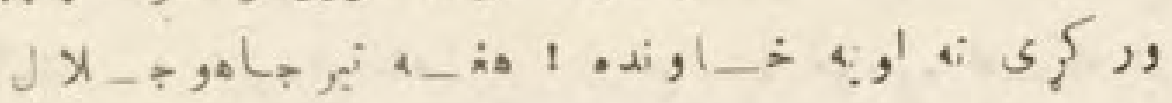

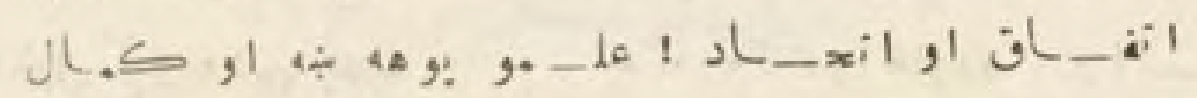

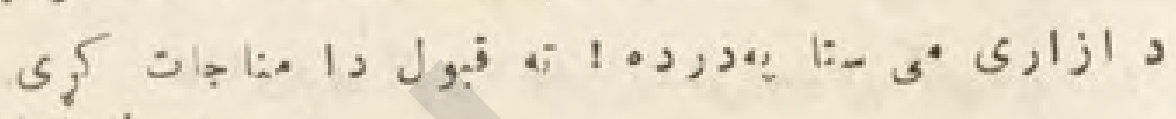

د

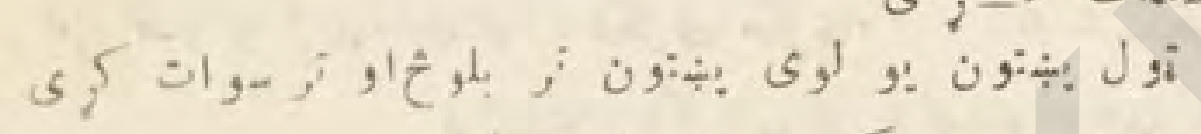

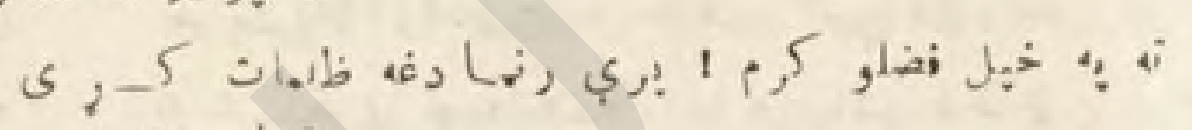

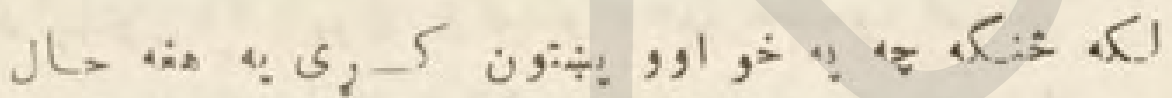

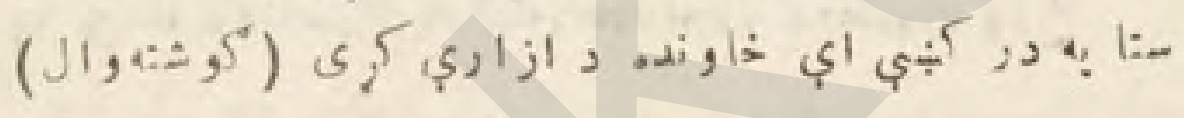

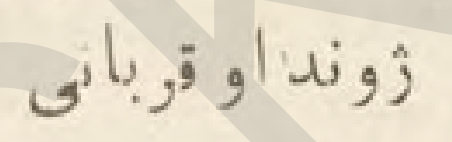

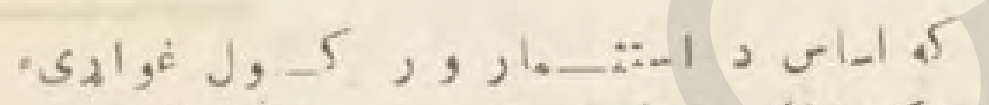
.

$$
\text { (i) }
$$

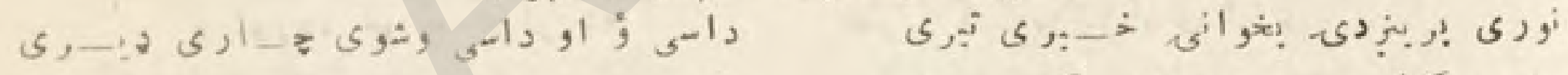

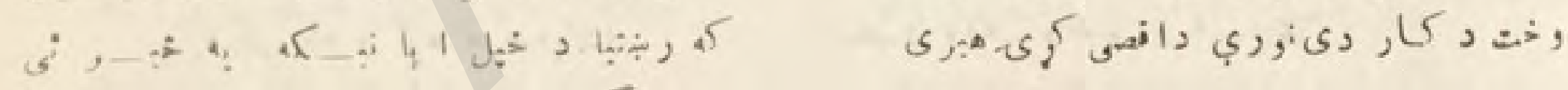

.

.

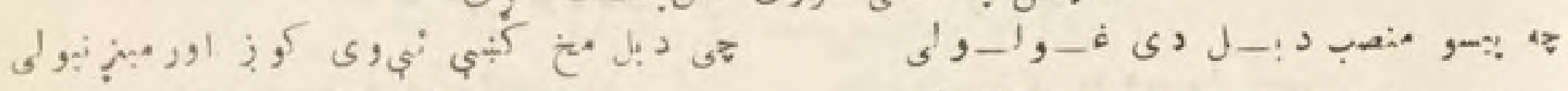

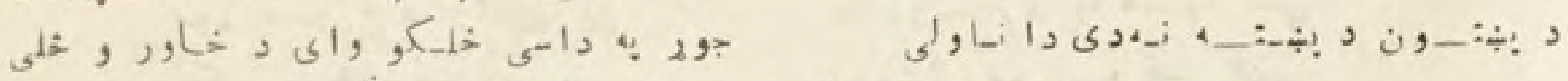

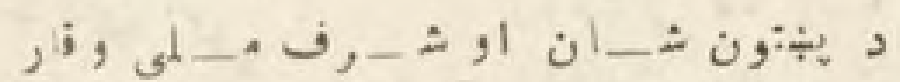

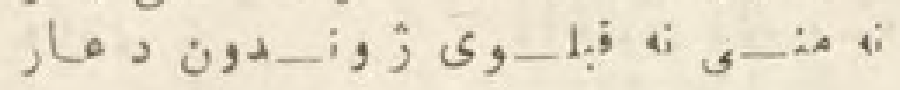

هن

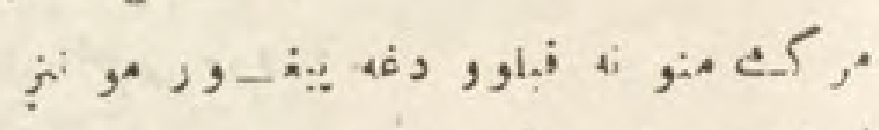

ن

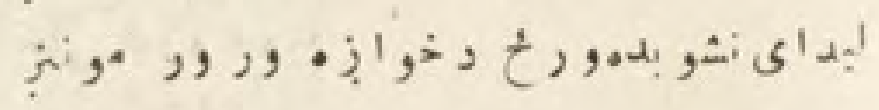

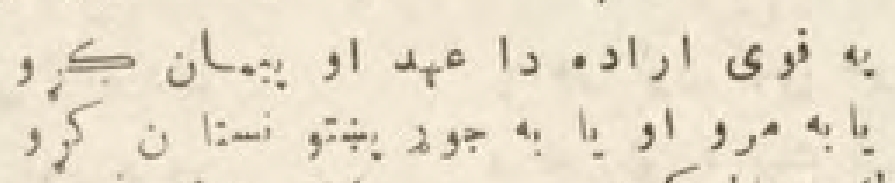

.

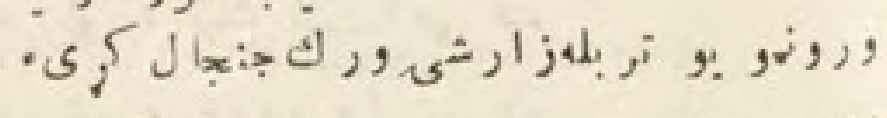

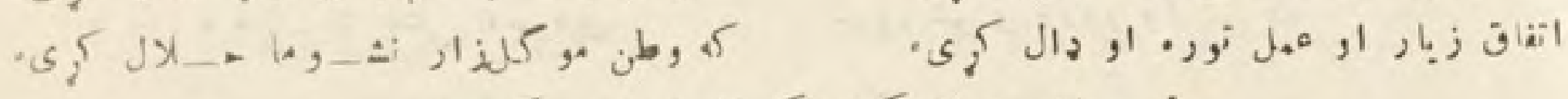

$$
\begin{aligned}
& \text {; }
\end{aligned}
$$

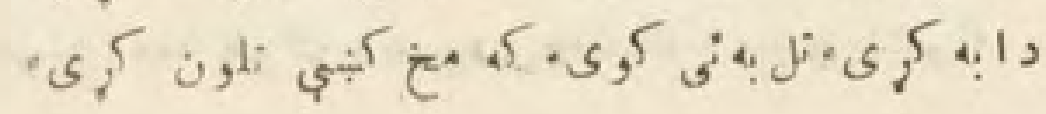


د ينبتونستان د وربنى به مناسبت

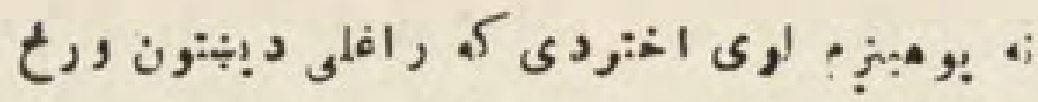

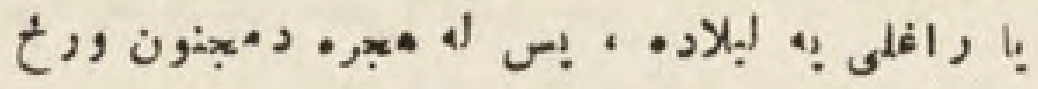

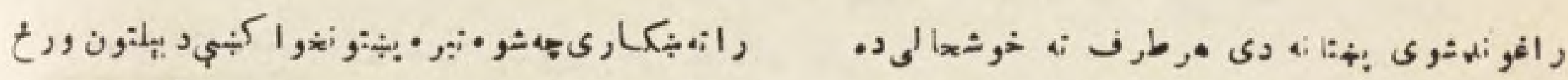

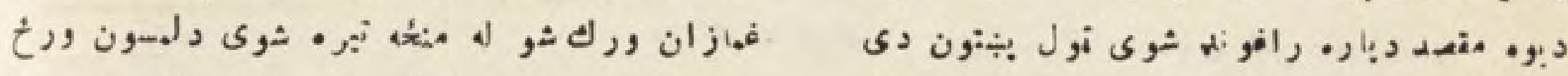

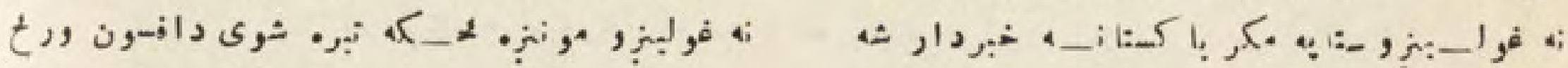

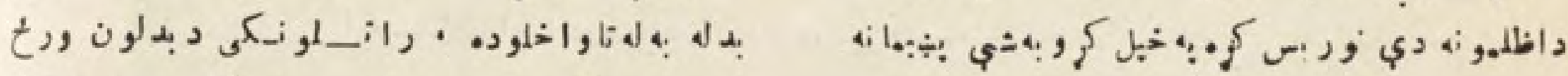

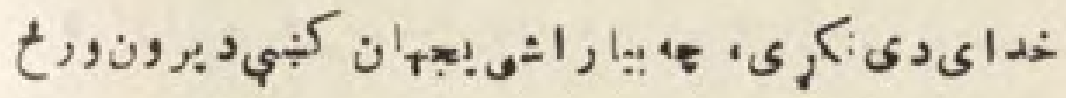

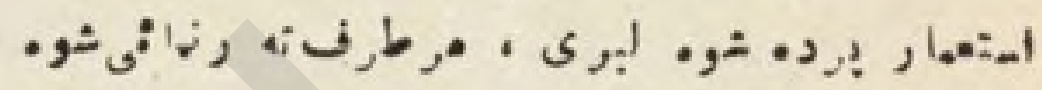

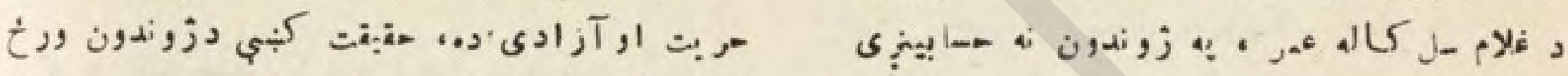

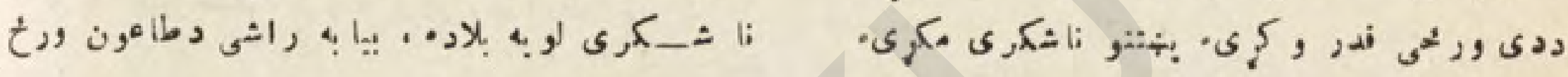

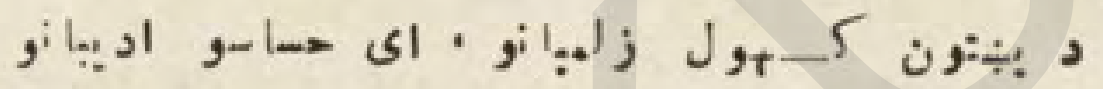

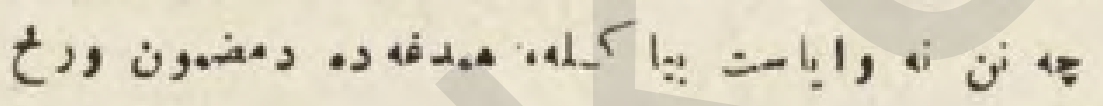

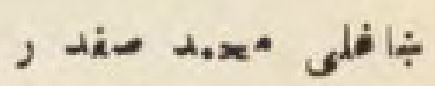 i 1 ,}

دينتونستان د ملم ورتحى جشن

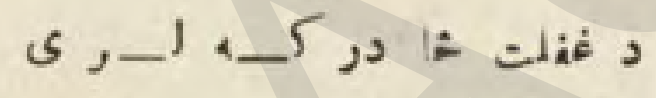

$$
\begin{aligned}
& \text { نظر, }
\end{aligned}
$$

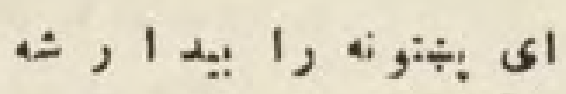

$$
\begin{aligned}
& \text { د. } \\
& \text { د إز } \\
& \text {; }
\end{aligned}
$$

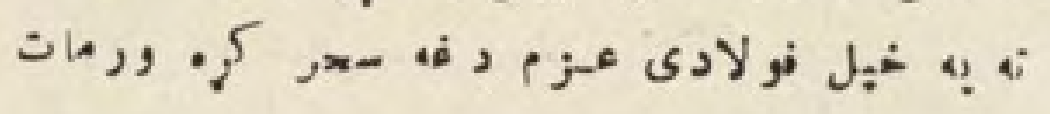

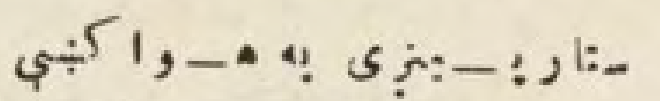

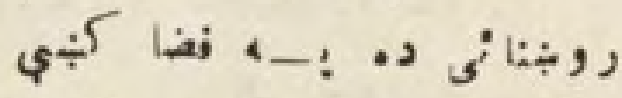

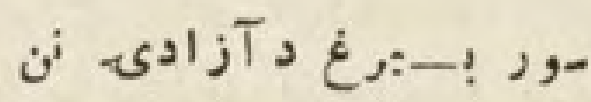

$$
\begin{aligned}
& \text { دان } \\
& \text { نكا }
\end{aligned}
$$

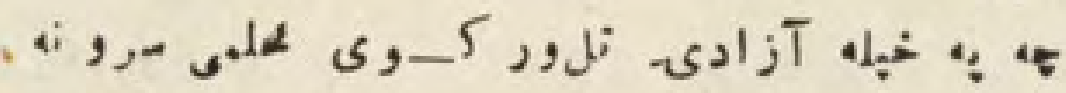

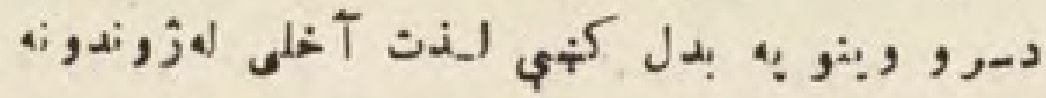

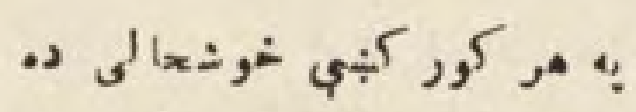

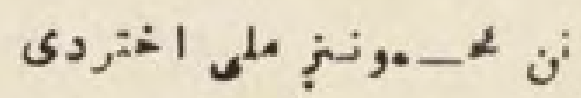

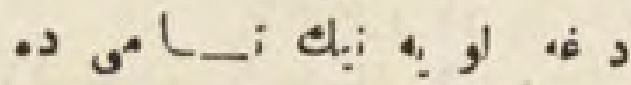

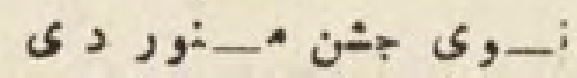

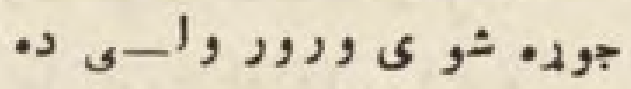

$$
\begin{aligned}
& \text { ى }
\end{aligned}
$$


(rr)

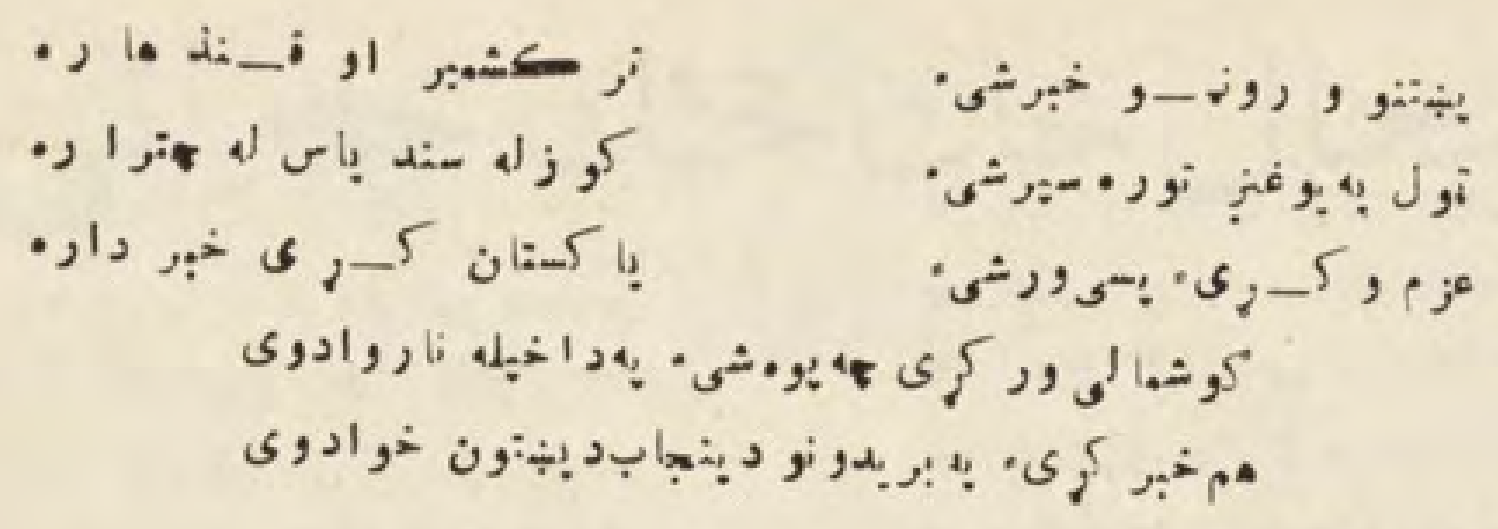

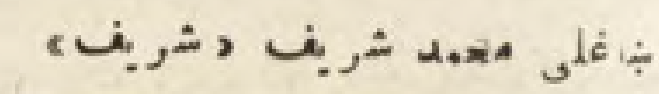

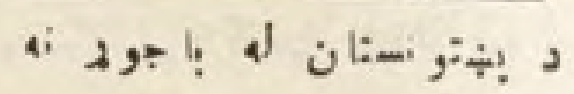

\section{دينهتونستان ورنح}

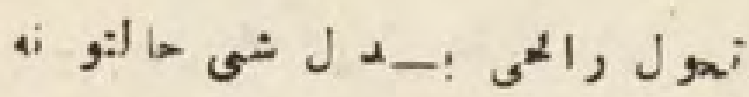

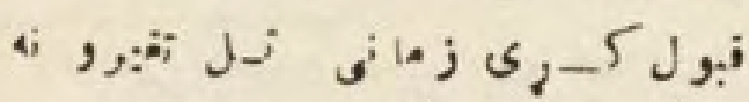

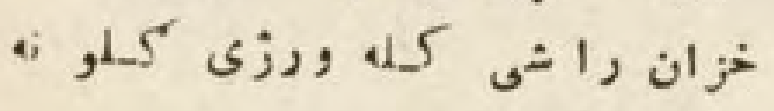

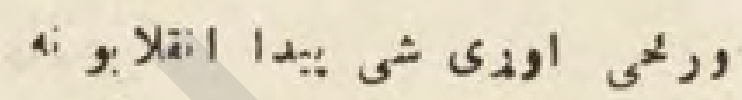

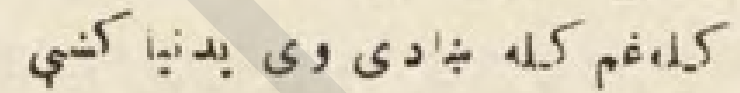

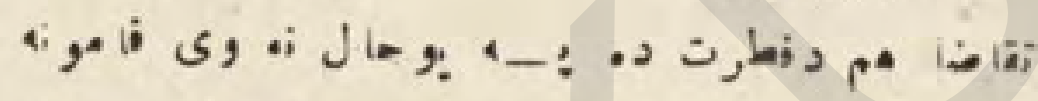

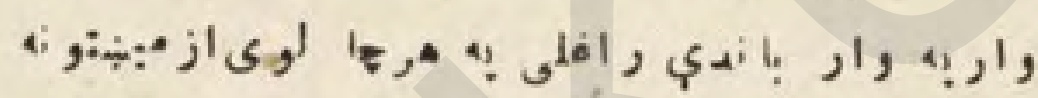

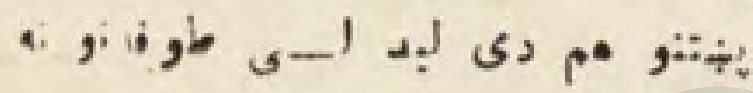

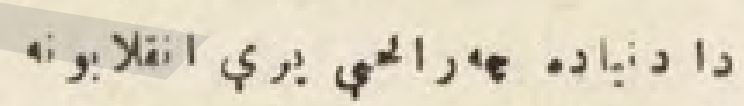

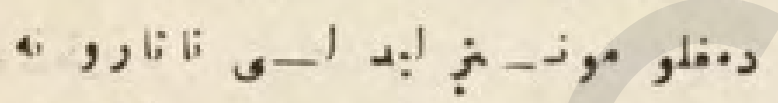

ه

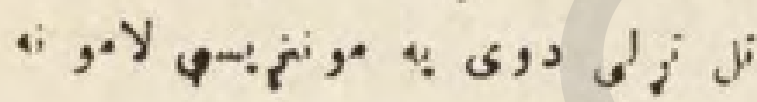

دى iر i

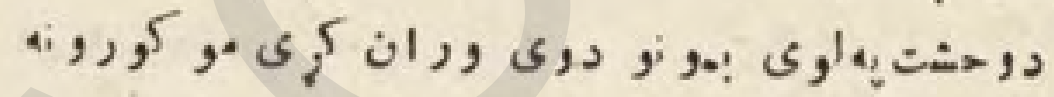

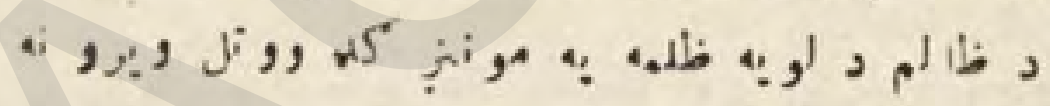

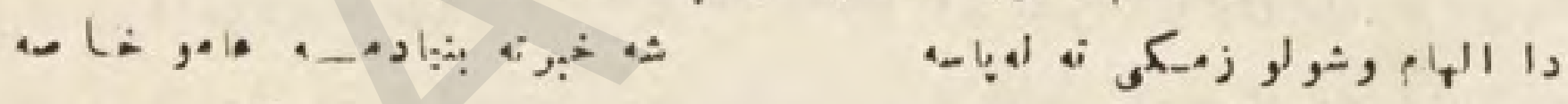

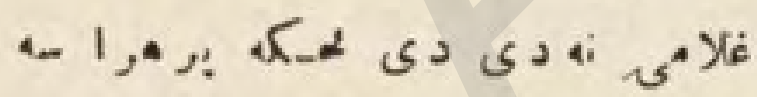

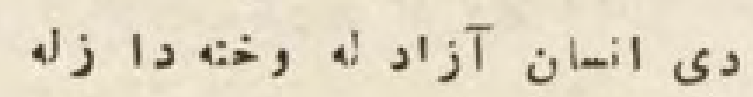

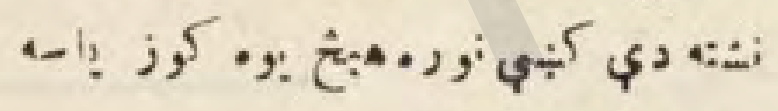

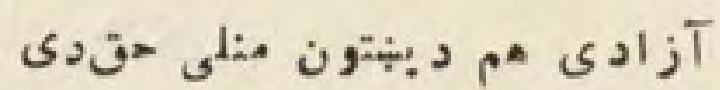

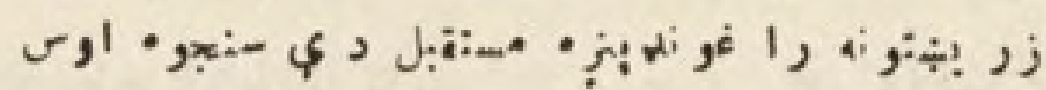

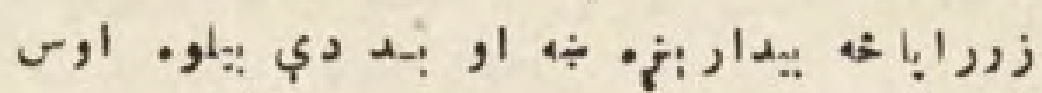

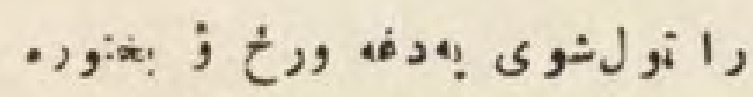

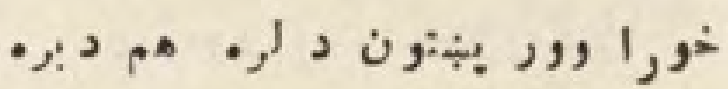

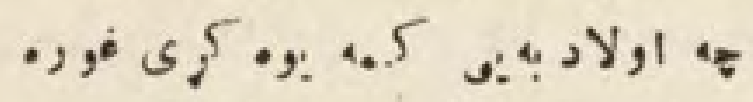

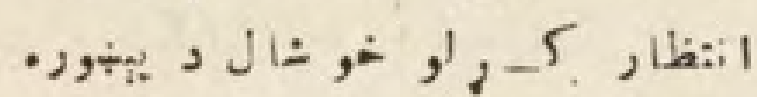

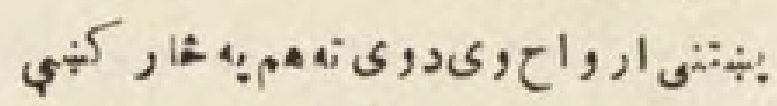

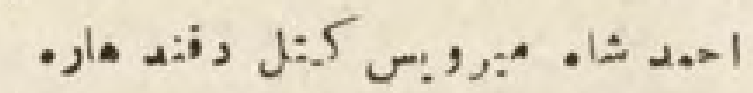

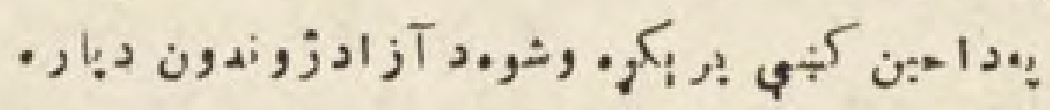

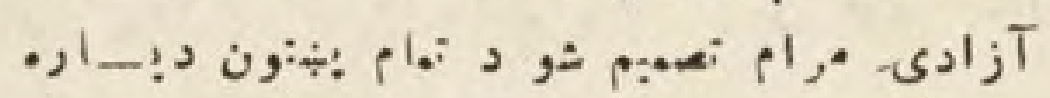

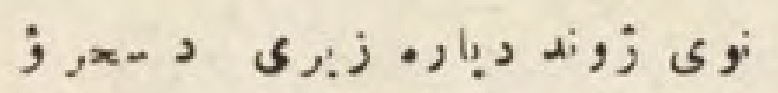

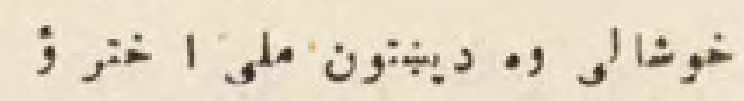

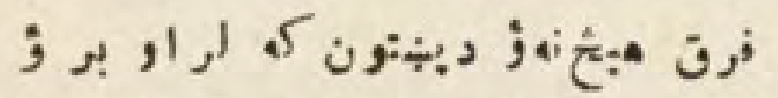

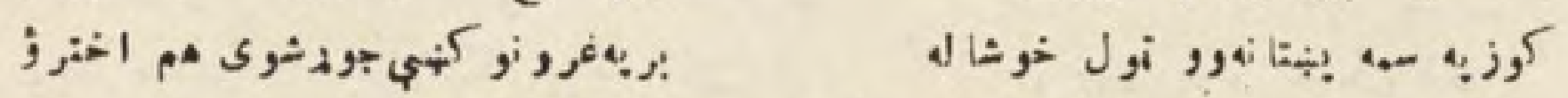

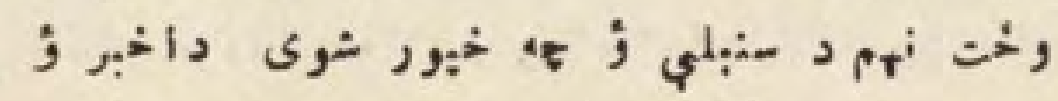

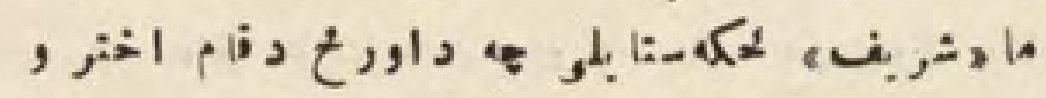


$(r i)$

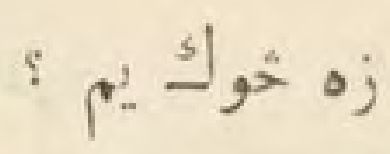

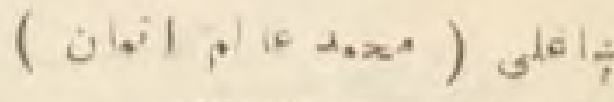

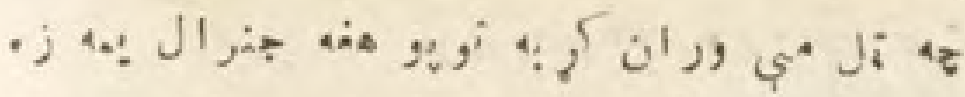

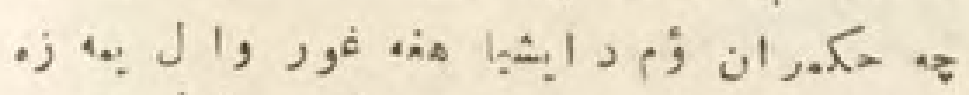

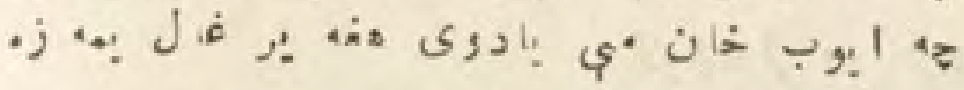
جه

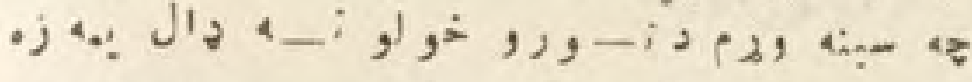
فं

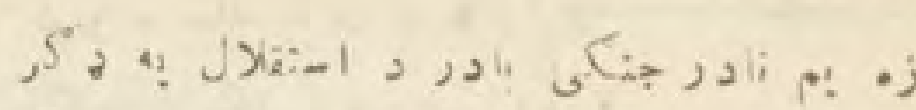

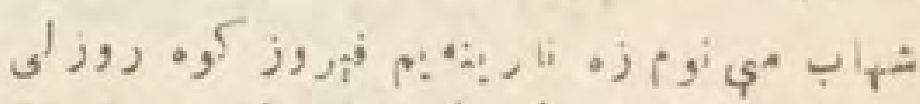

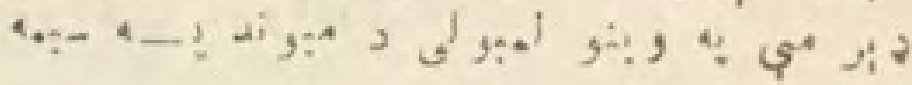

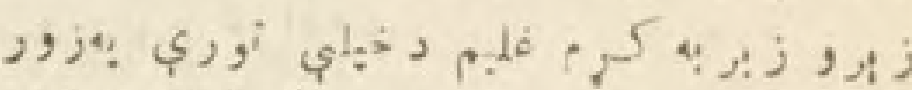

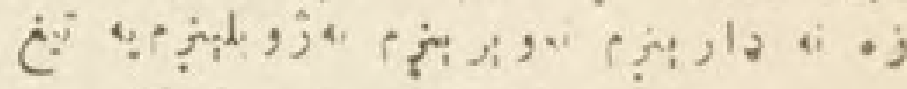

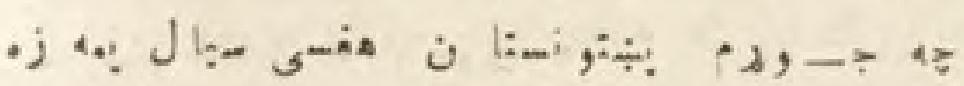

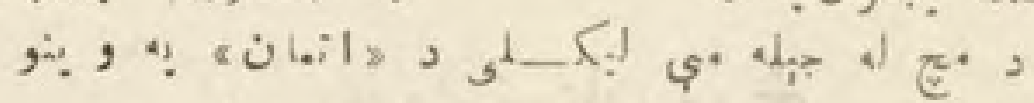

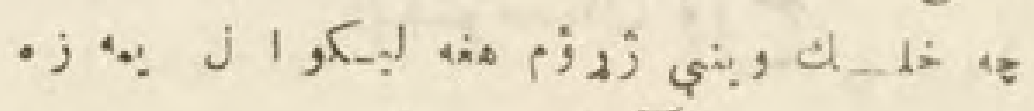

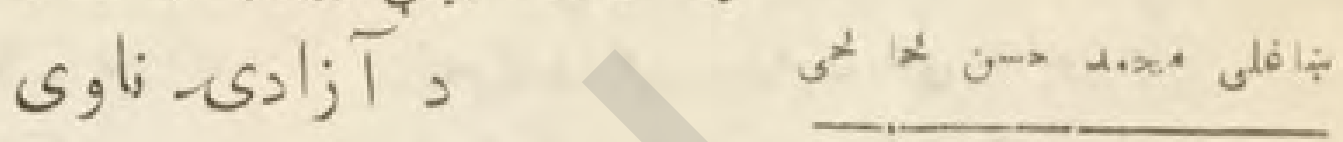

J

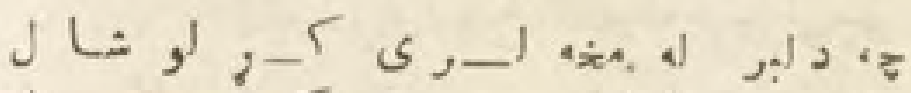

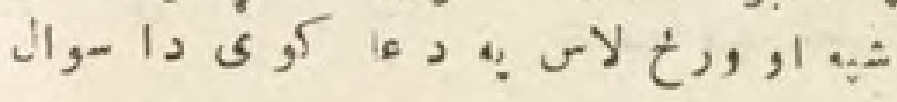

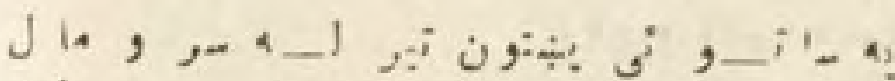

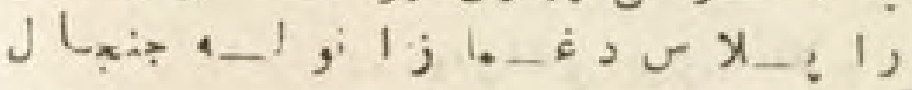

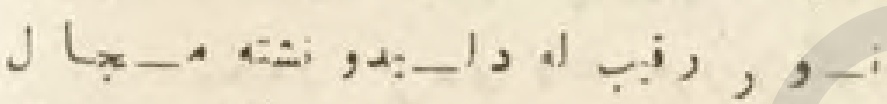

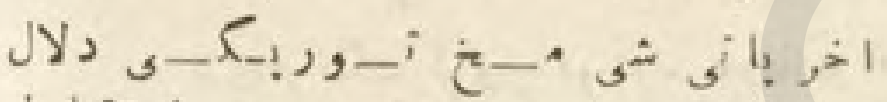

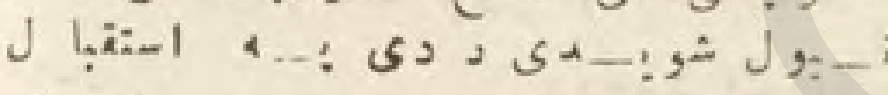

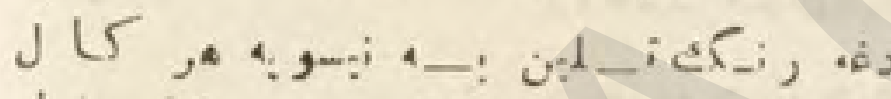

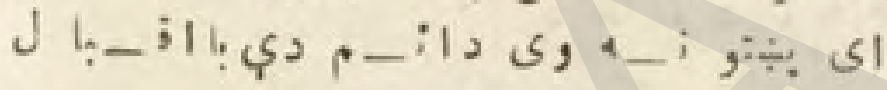

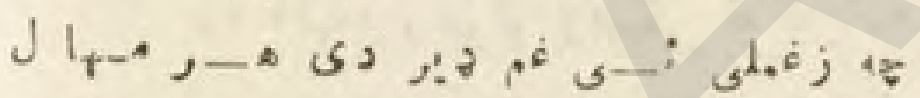

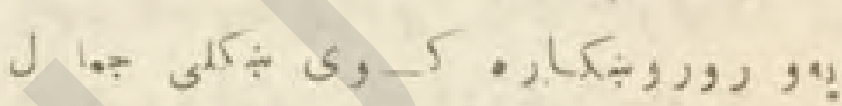

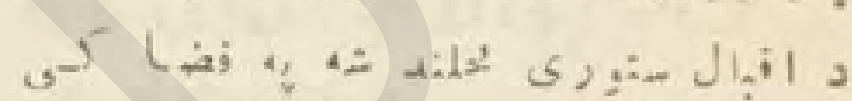

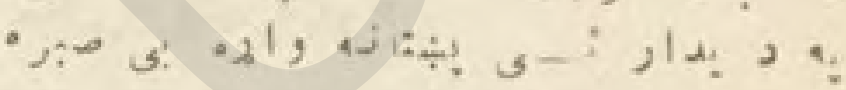

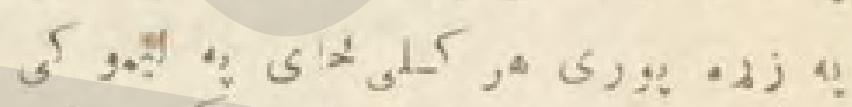
د • al

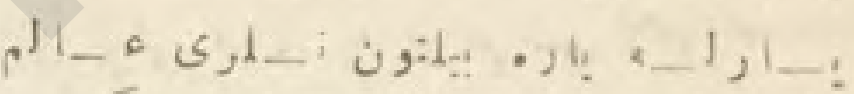
ك-

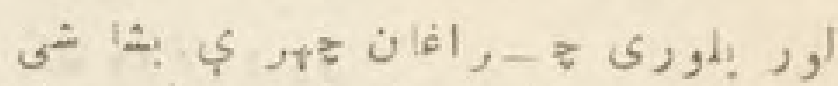

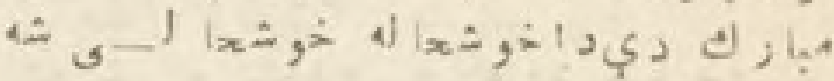

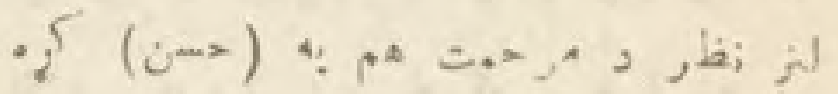

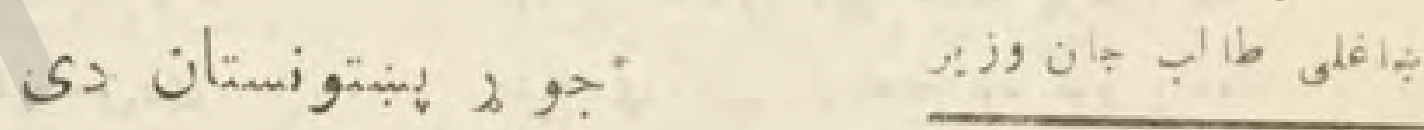

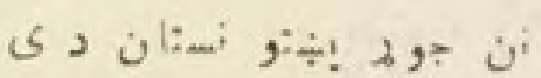

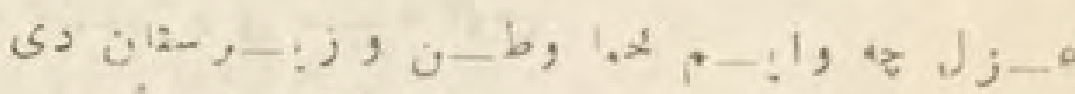

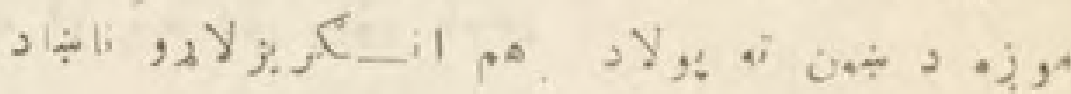

$$
\begin{aligned}
& \text { ى } \\
& \text { ى }
\end{aligned}
$$

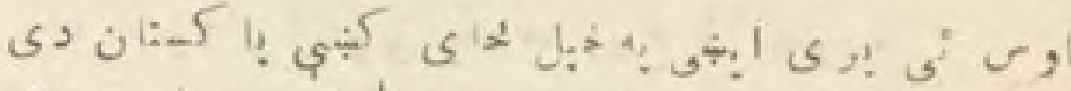

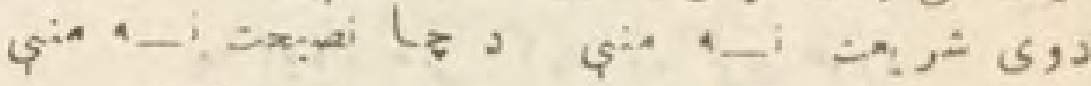

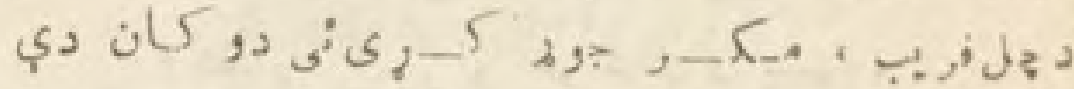

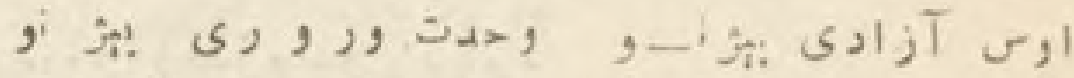

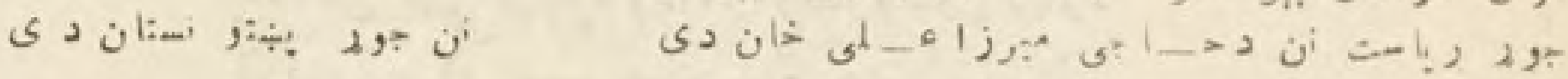

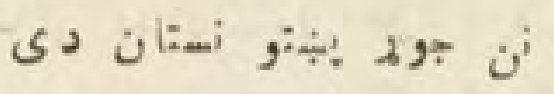

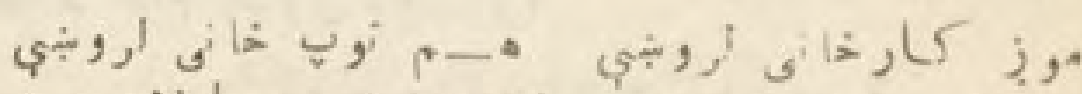

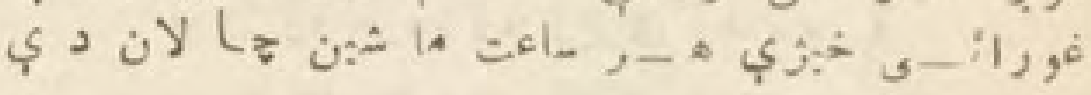

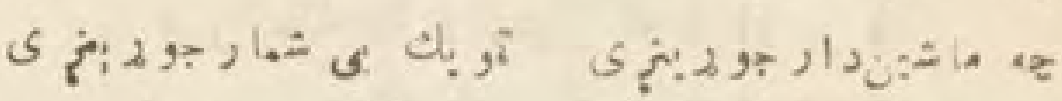

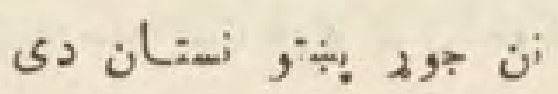

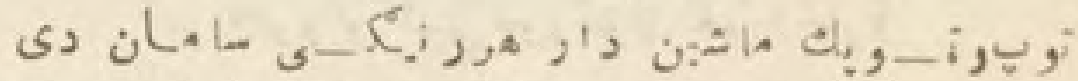

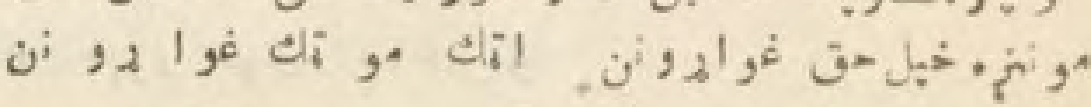

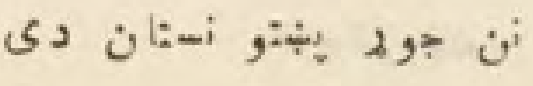

$$
\begin{aligned}
& \text { = }
\end{aligned}
$$




$$
\begin{aligned}
& \text { خو شعال خان ختيك خُهو ادى } \\
& \text { ( }(\dot{2}, \div)
\end{aligned}
$$

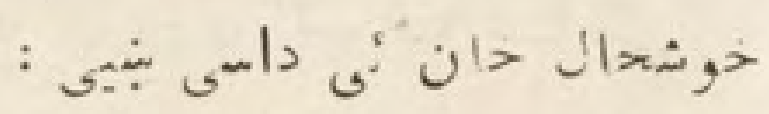

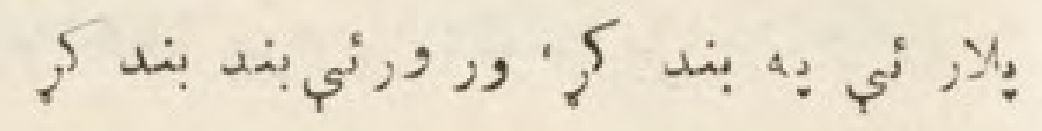

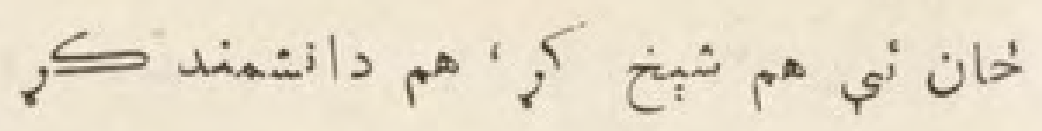

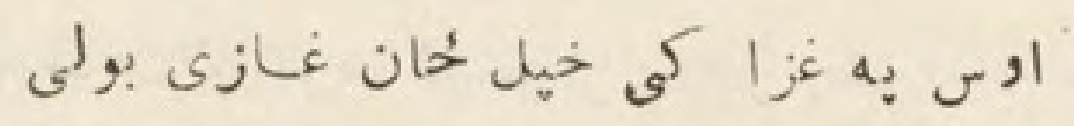

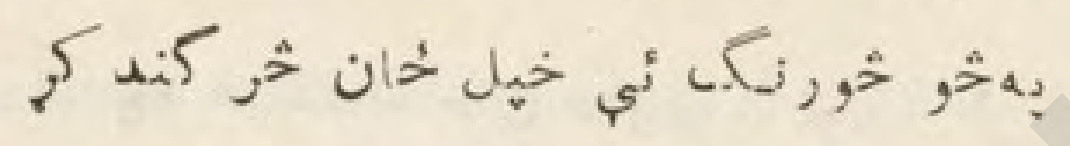

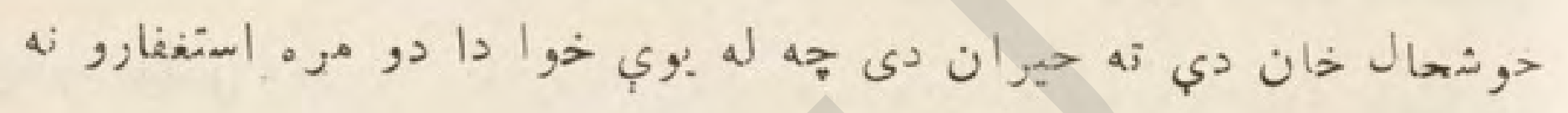

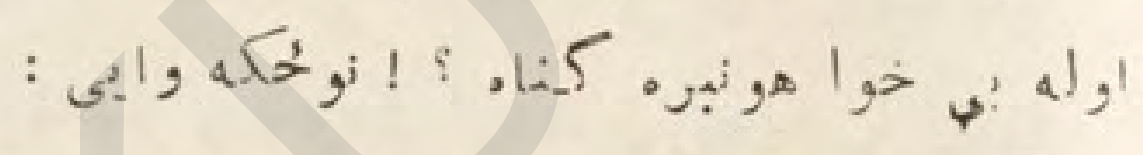

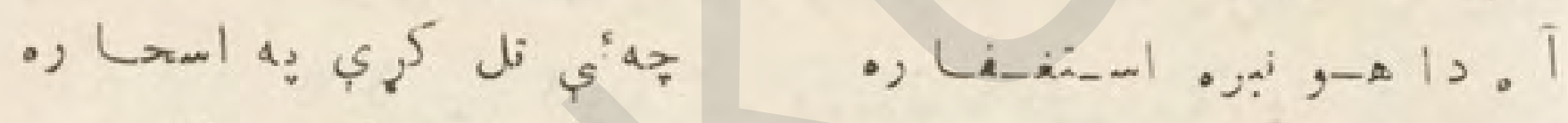

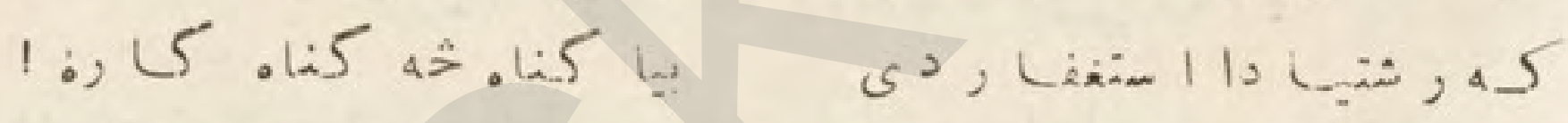

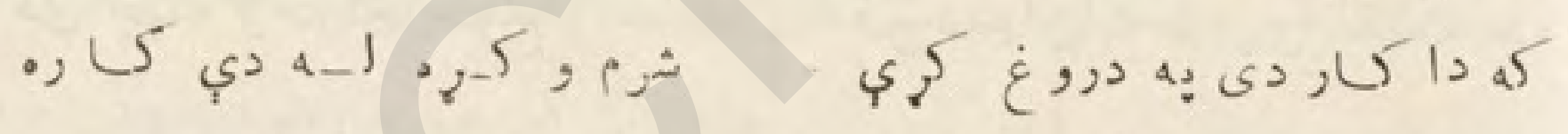

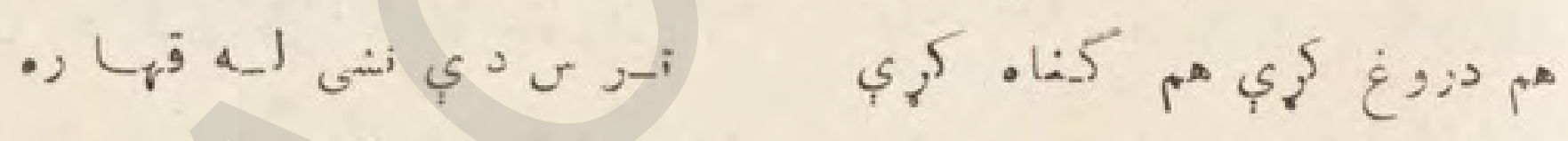

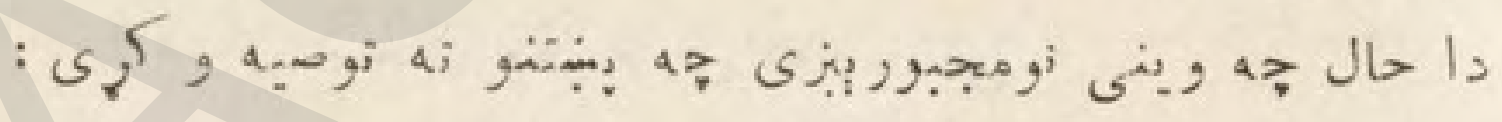

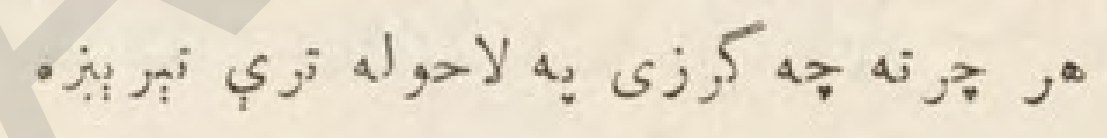

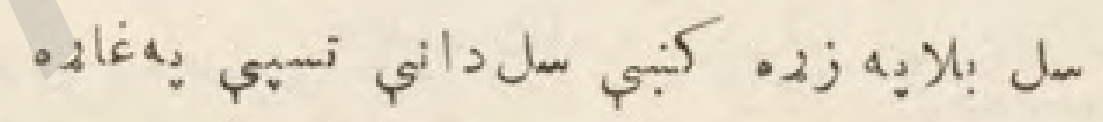

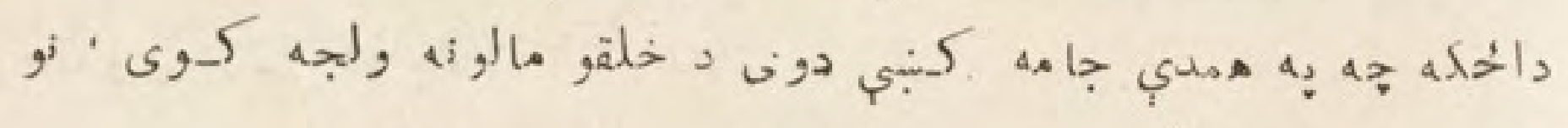

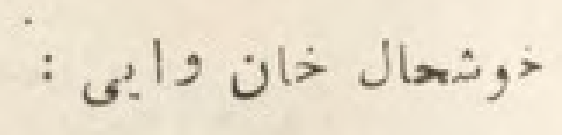

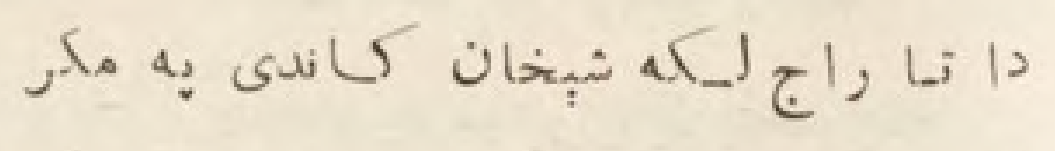

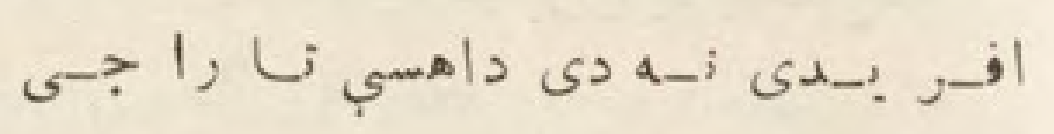

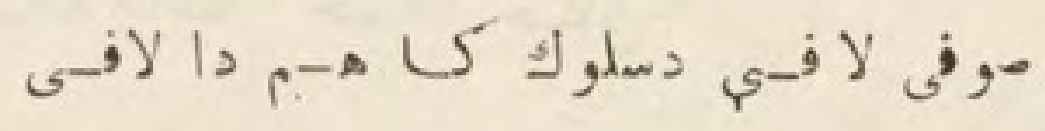

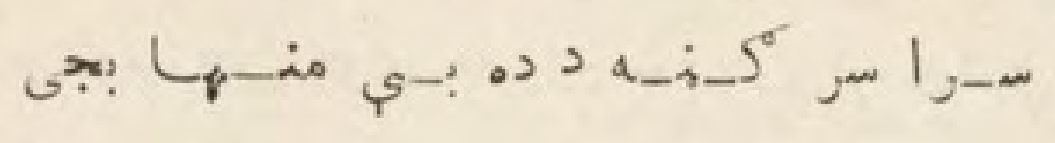

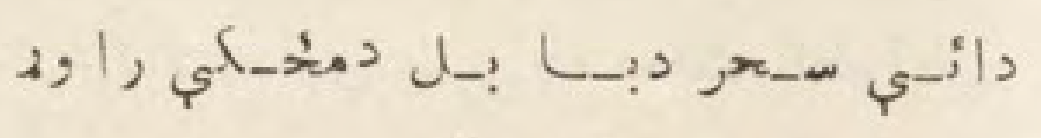

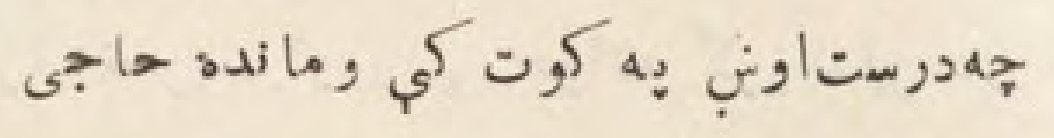




\section{(rq)}

$$
\begin{aligned}
& \text { صف أي }
\end{aligned}
$$

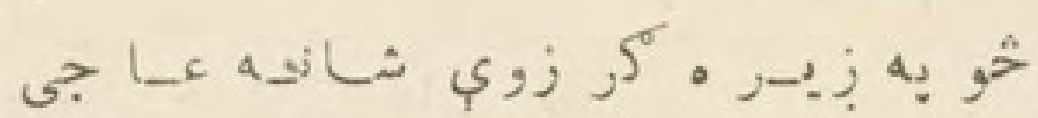

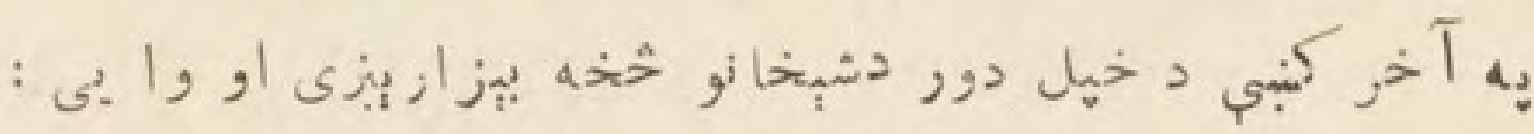

$$
\begin{aligned}
& \text { ددي دور د شنخا نو حال مى و كوت }
\end{aligned}
$$

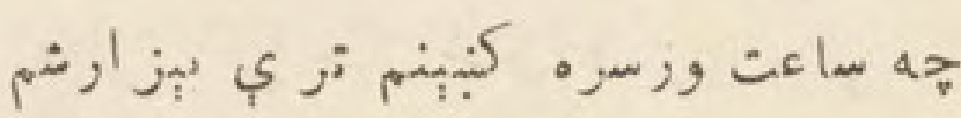

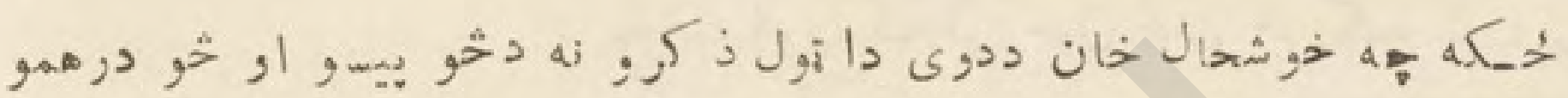

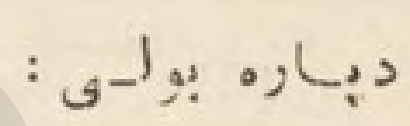

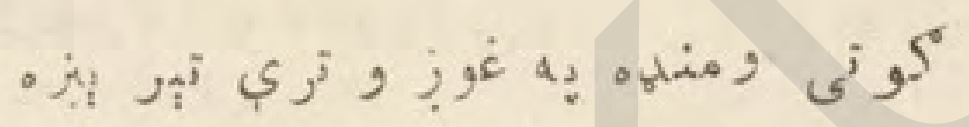

$$
\text { نا كرز }
$$

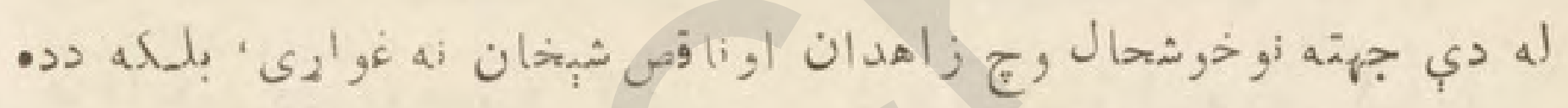

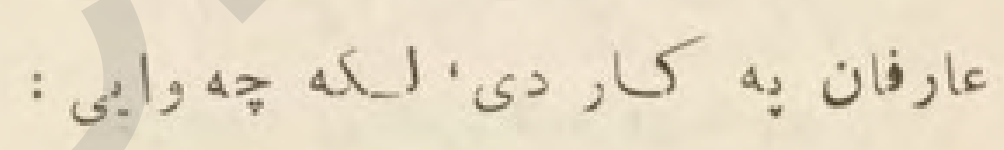

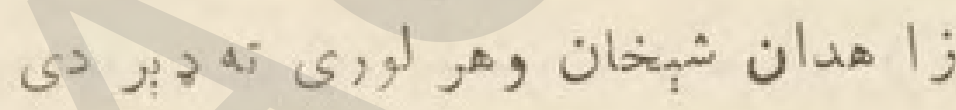

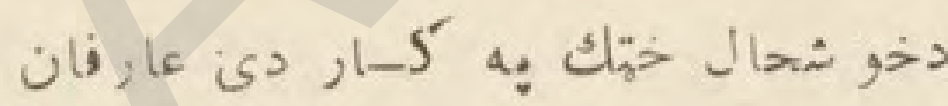

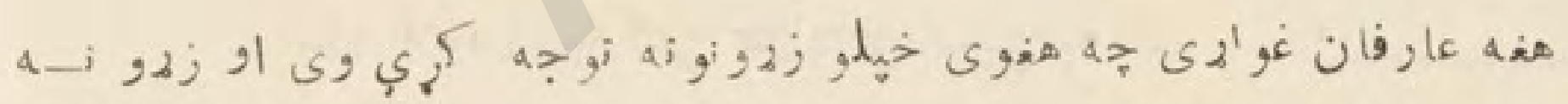

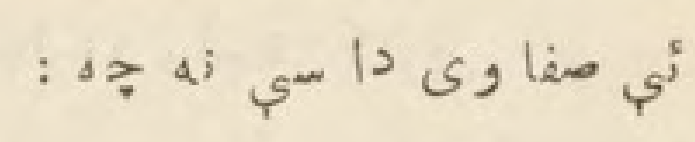

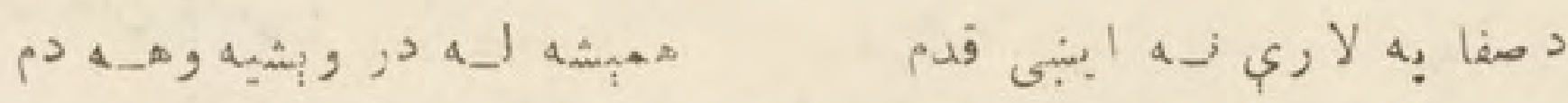

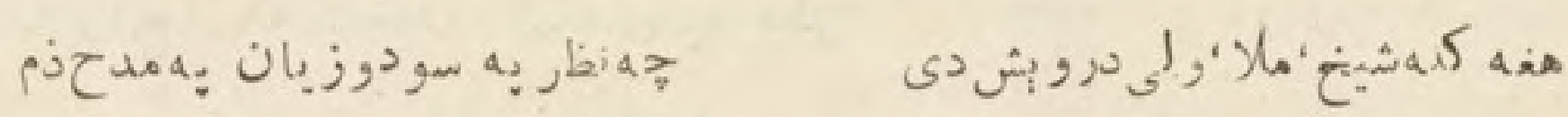

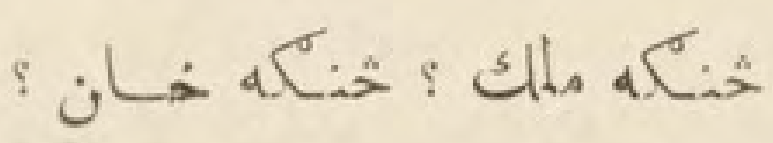

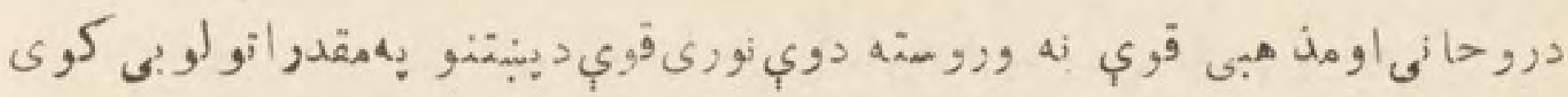

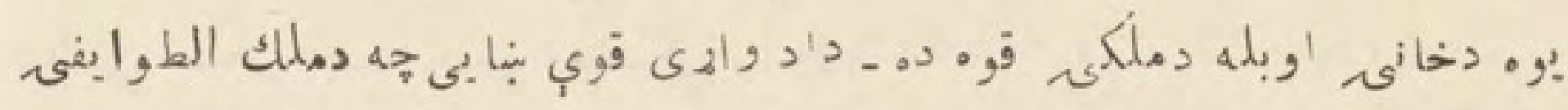

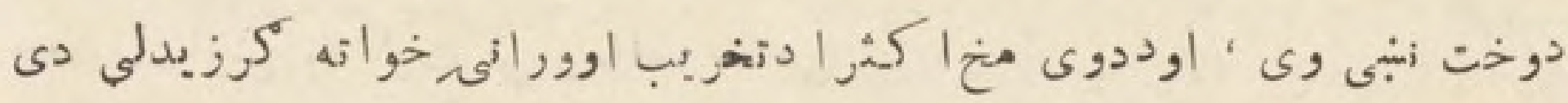




\section{(rv)}

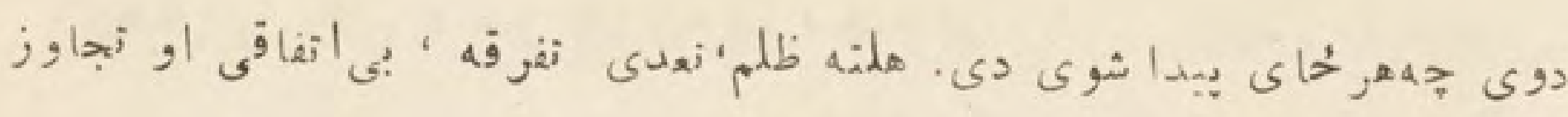

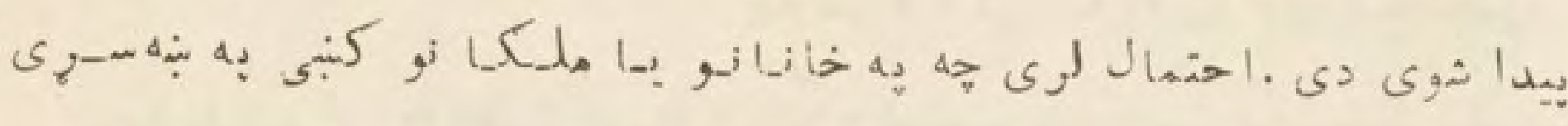

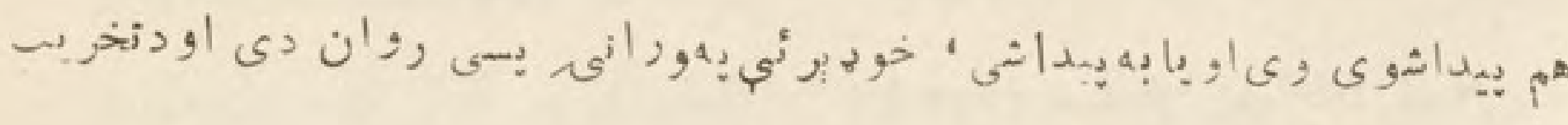

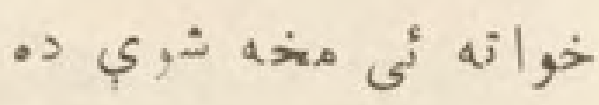

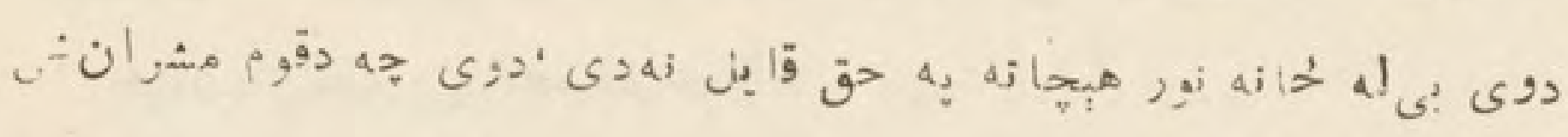

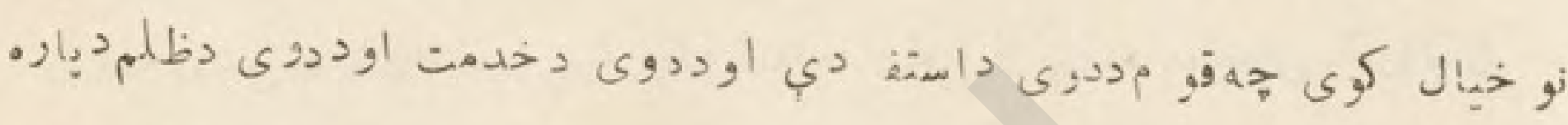

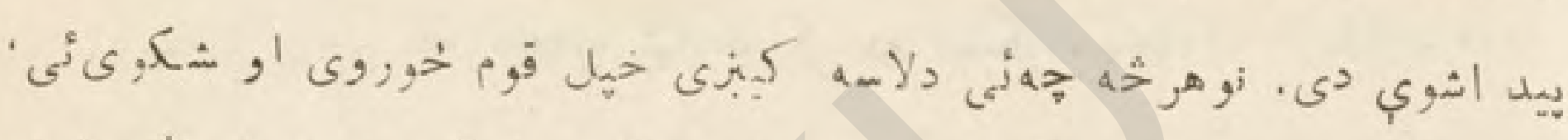

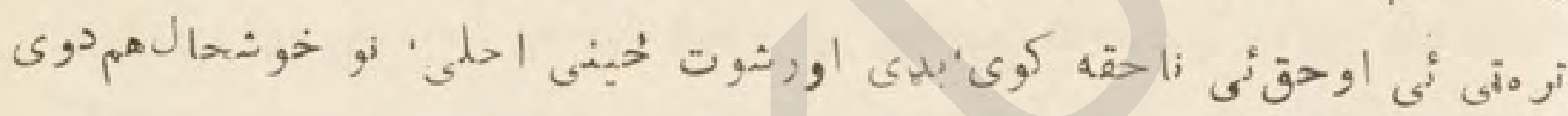

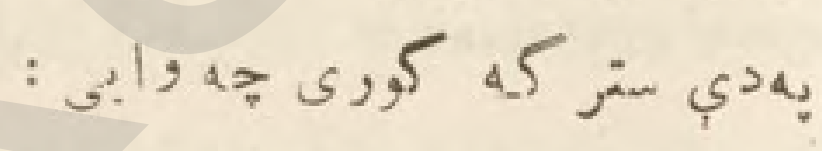

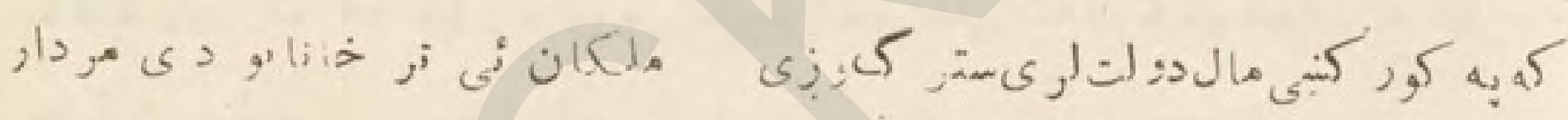

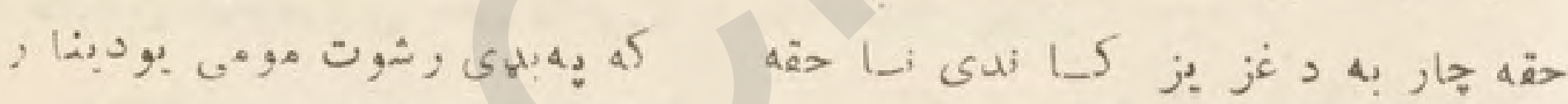

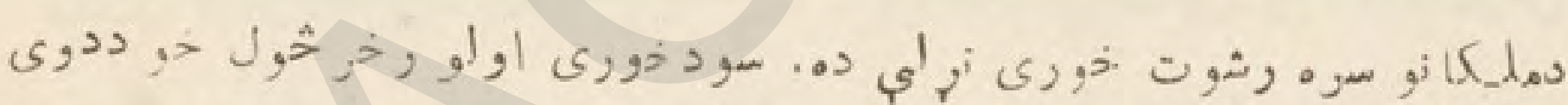

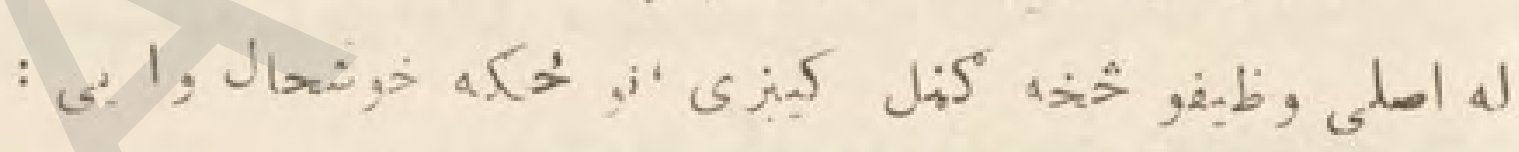

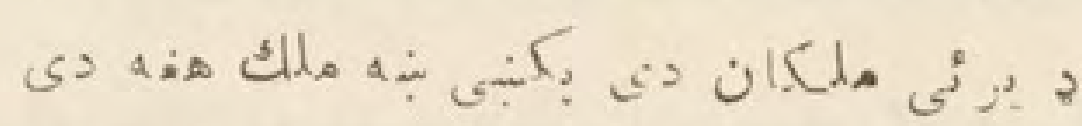

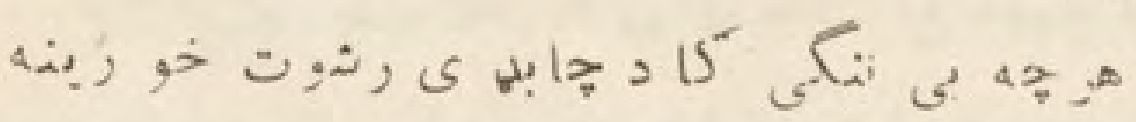

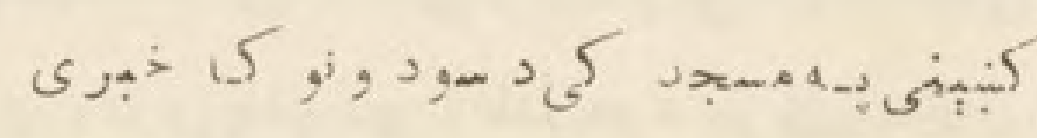

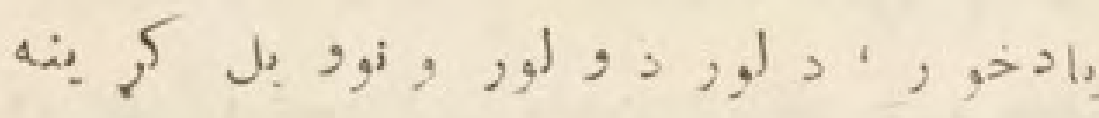

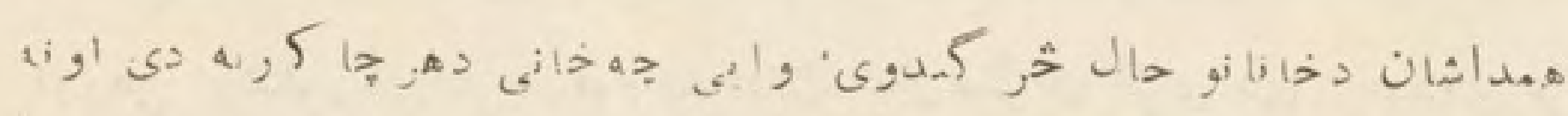

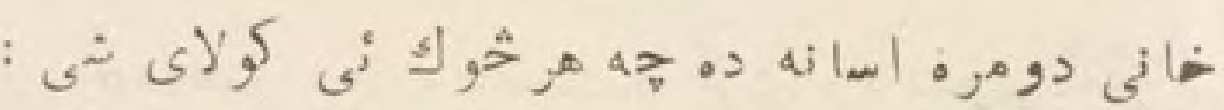

$$
\begin{aligned}
& \text { a.j }
\end{aligned}
$$

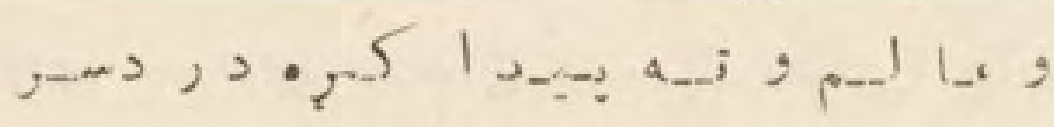




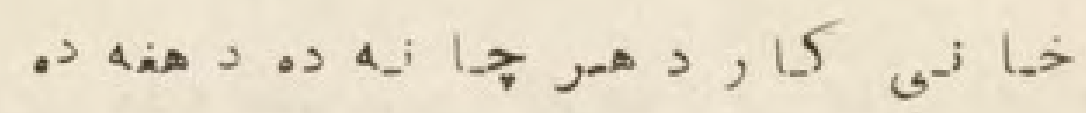

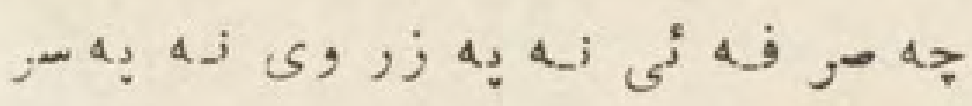

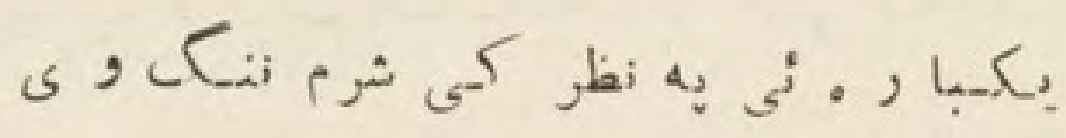

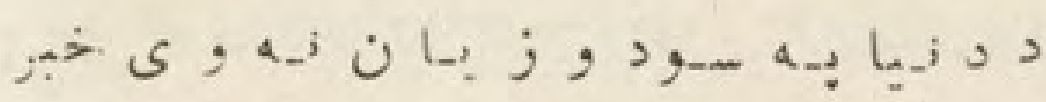

$$
\begin{aligned}
& \text { بل كُأى د حقيقى او درست خان إوصاف د اسى خركند وكى : }
\end{aligned}
$$

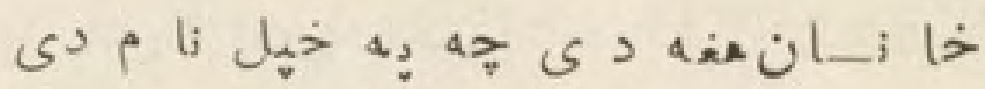

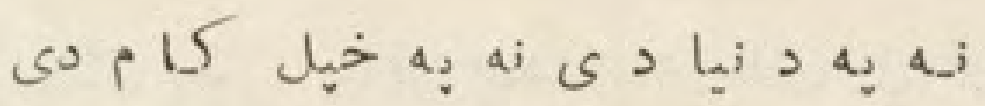

$$
\begin{aligned}
& \text { جه ده كوم نو كى دقامبنيكر • وى }
\end{aligned}
$$

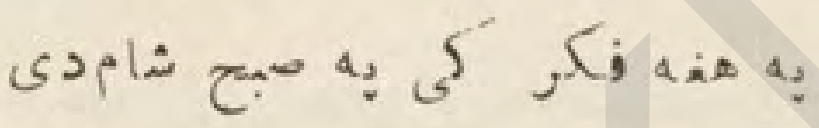

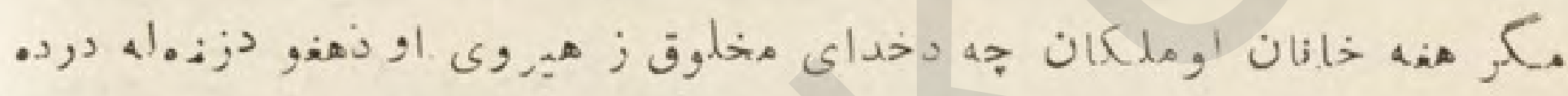

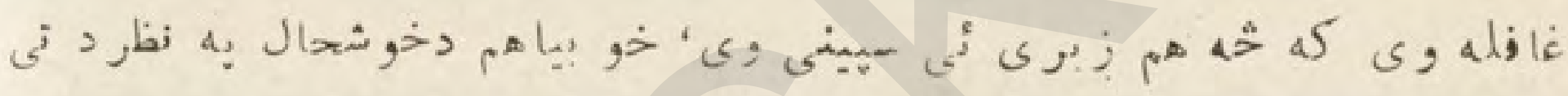

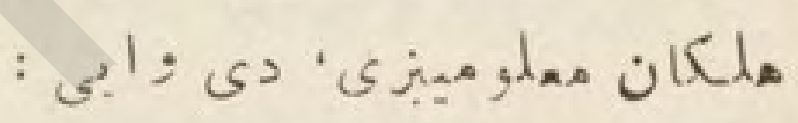

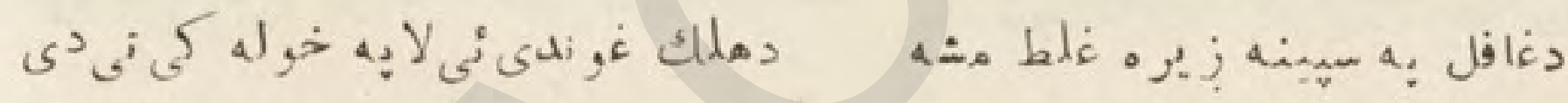

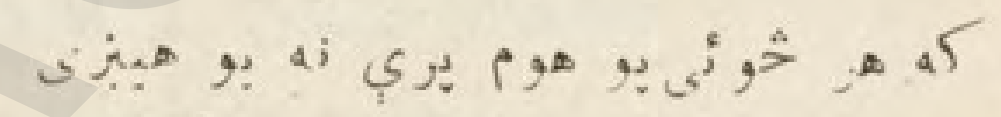

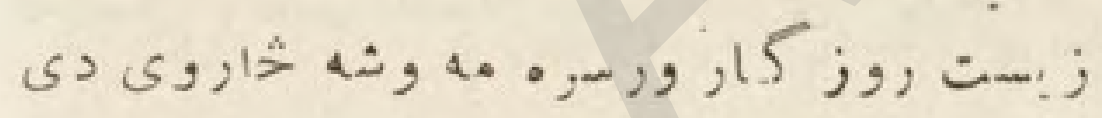

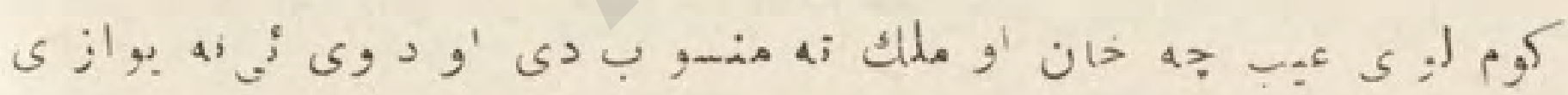

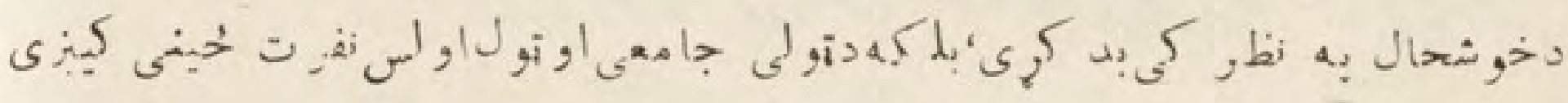

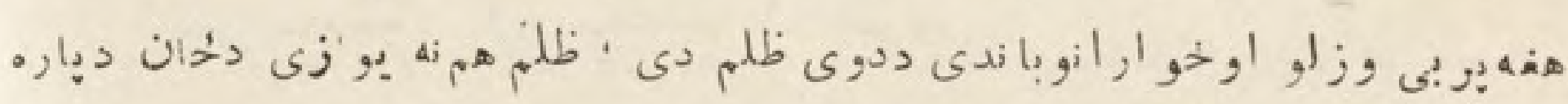

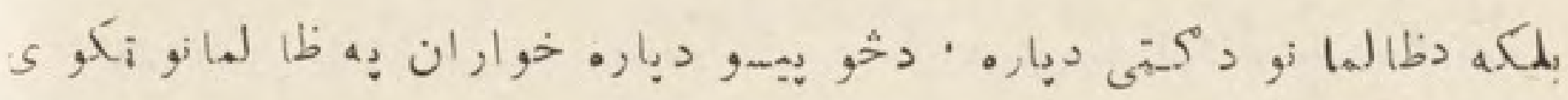

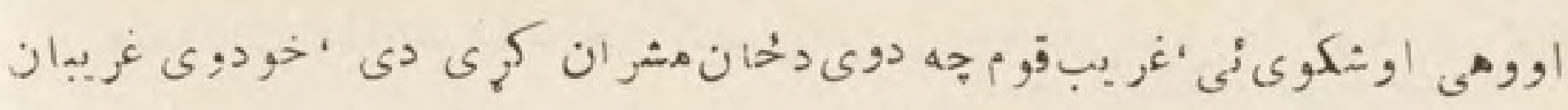

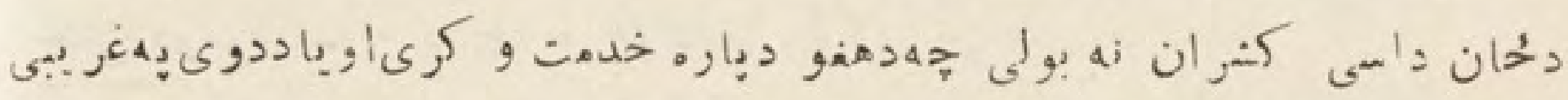

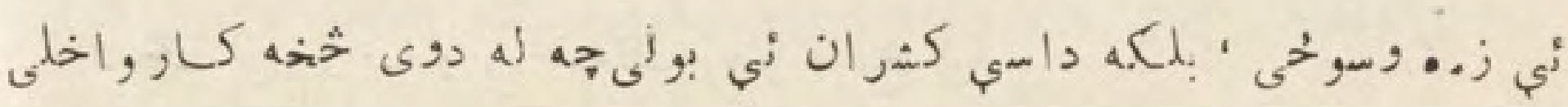

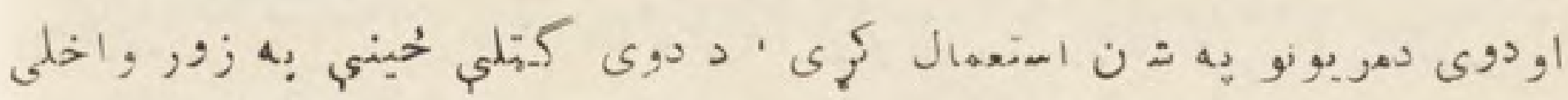




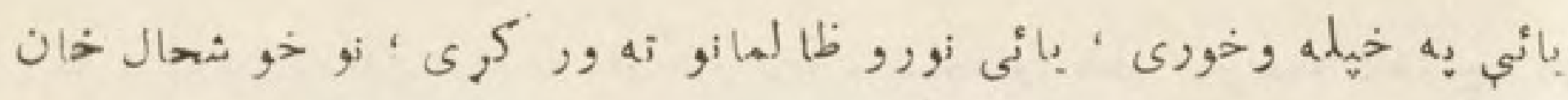

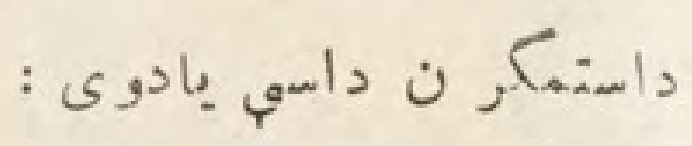

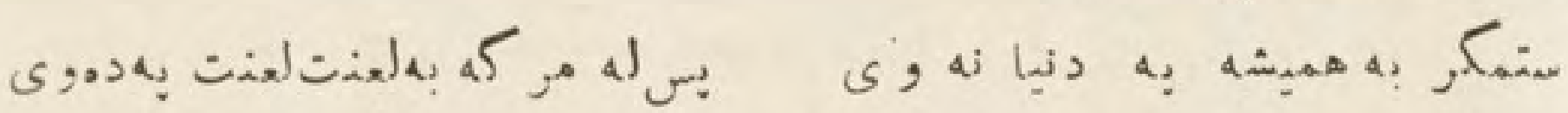

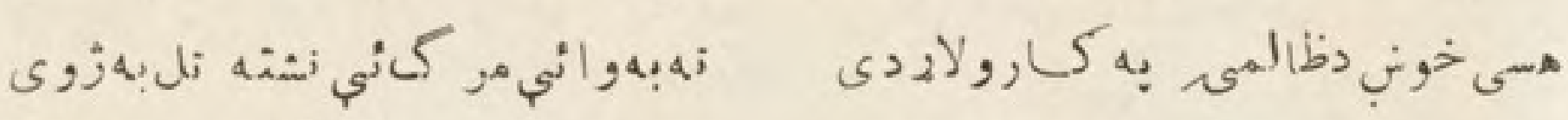

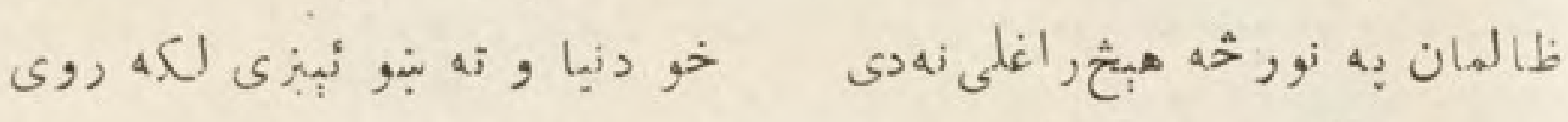

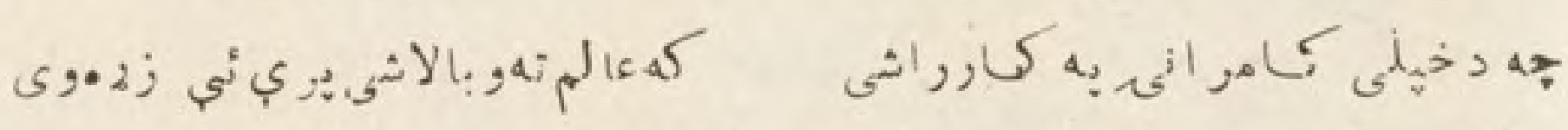

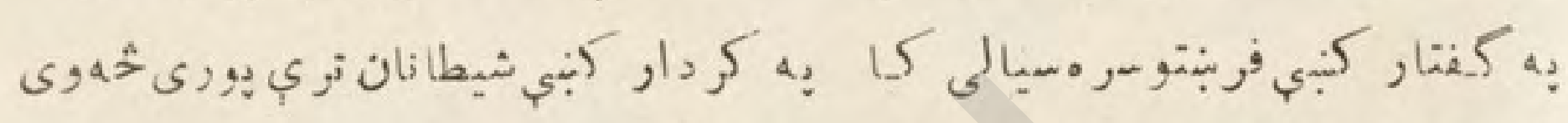

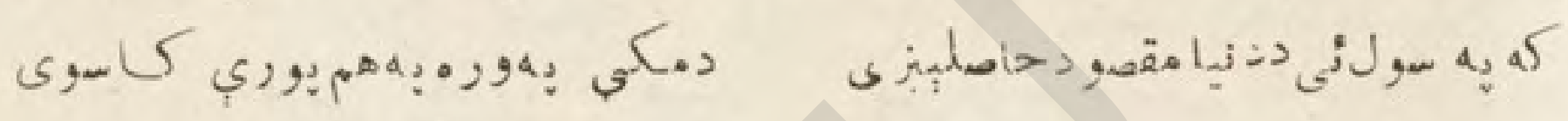

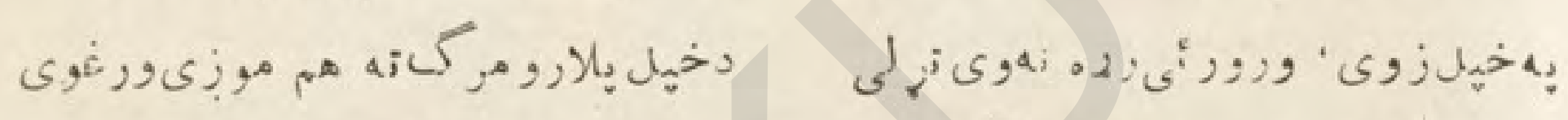

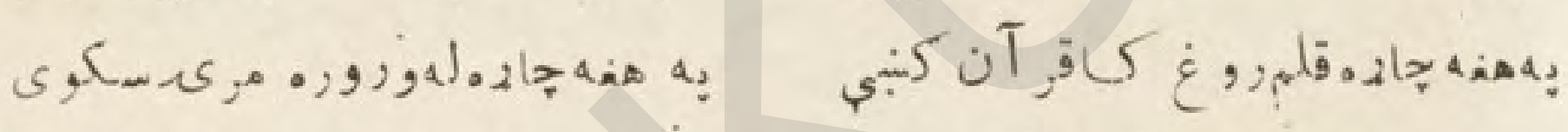

$$
\begin{aligned}
& \text { IS }
\end{aligned}
$$

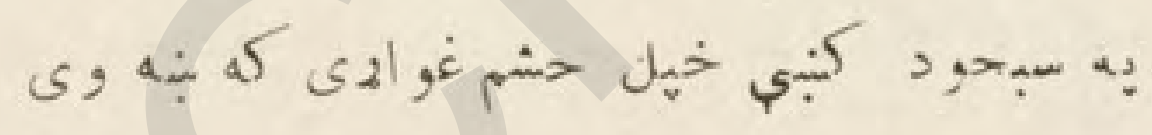

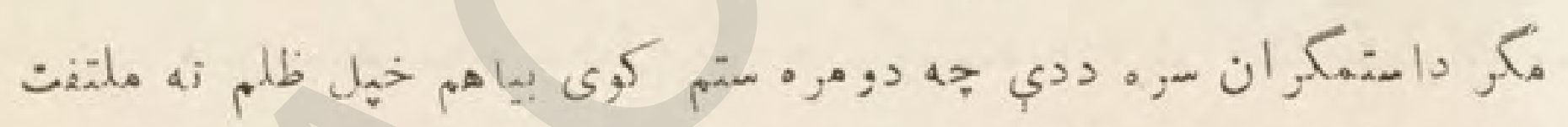

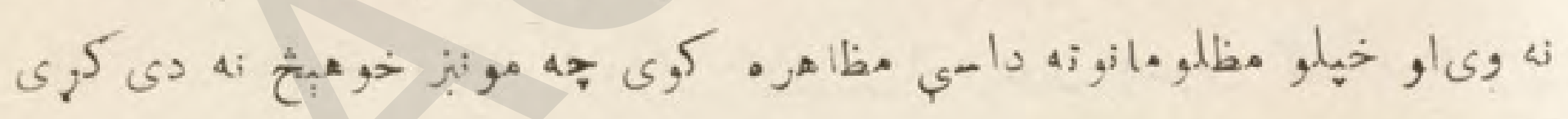

$$
\text { : إئ }
$$

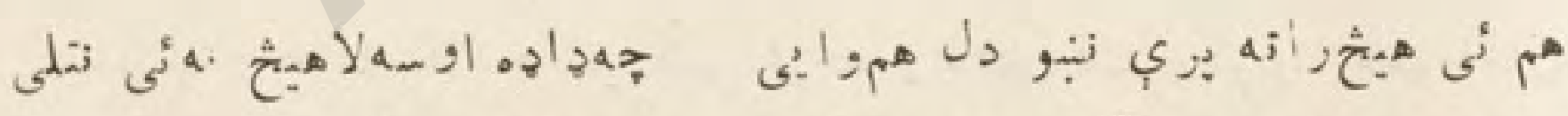

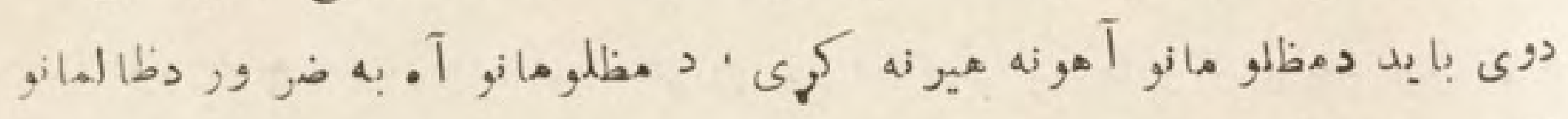

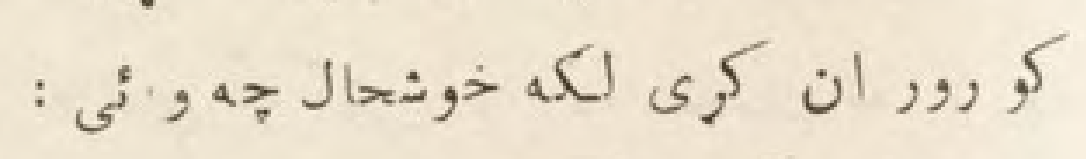

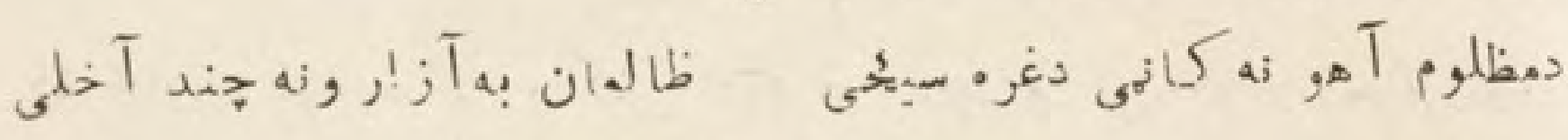

$$
\text { (c) (क) }
$$

$$
\begin{aligned}
& \text { : }
\end{aligned}
$$

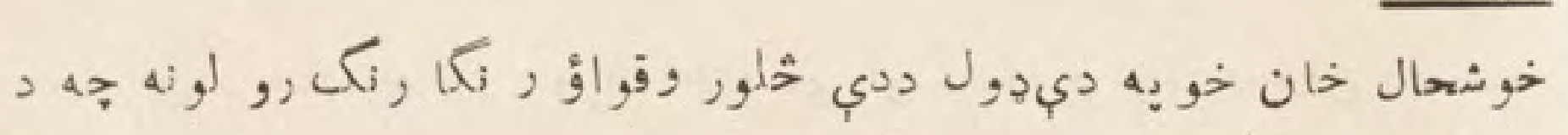

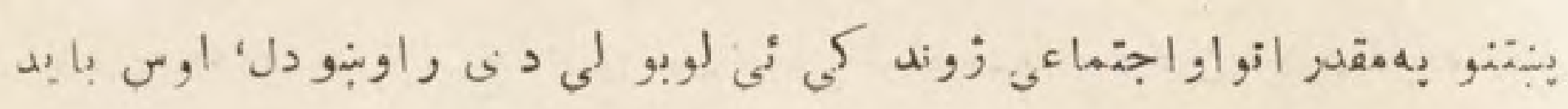




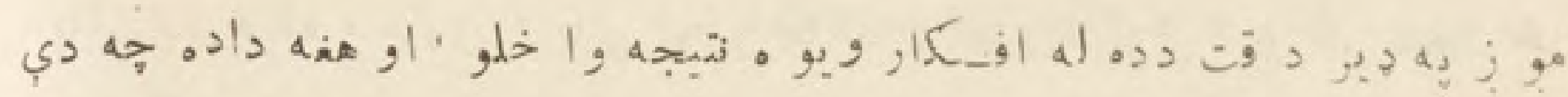

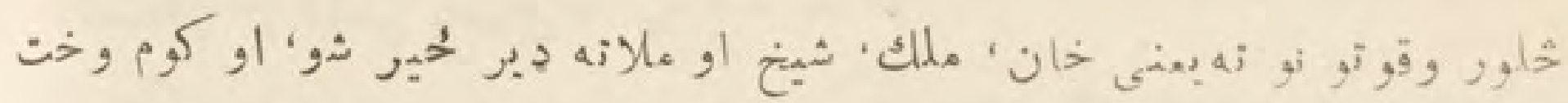
جه غوا2 إ جه دوى ز موبز به مخ كنبى شى' زو به انتخا ب كنبى ئى زبنت

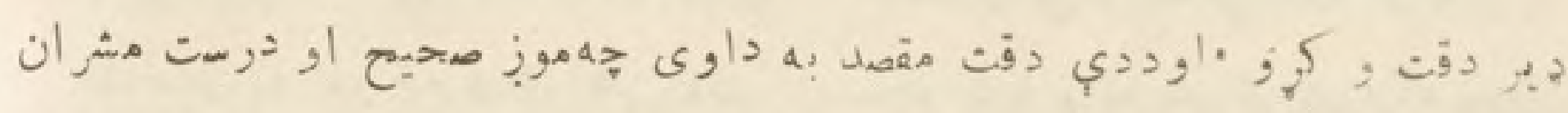
جا :

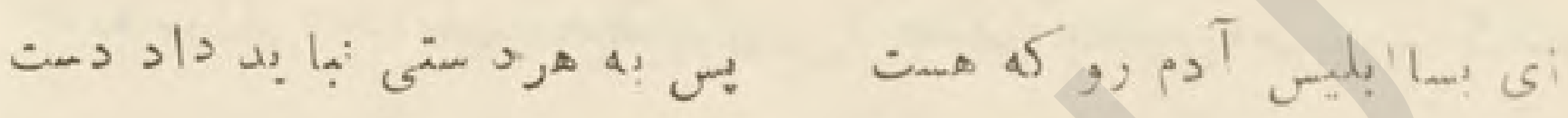
放

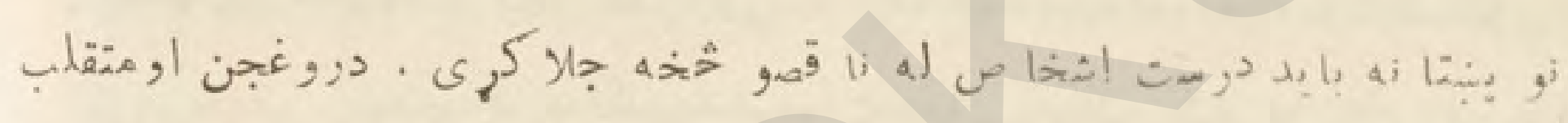

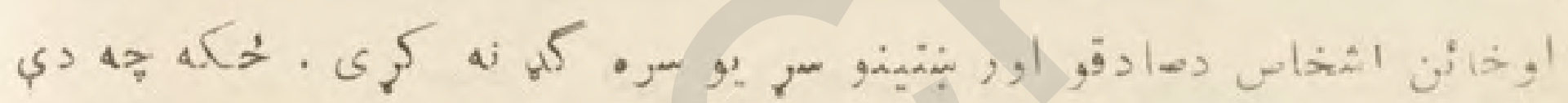

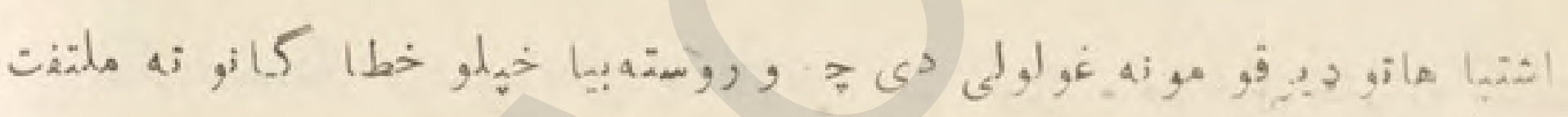

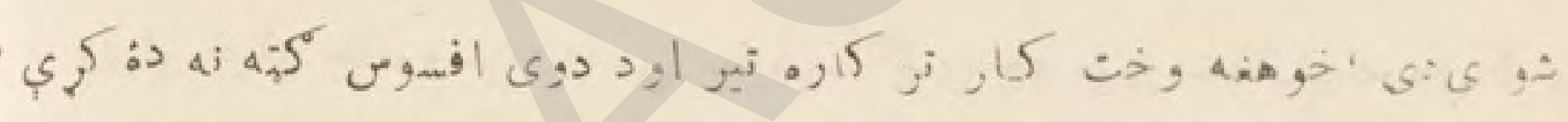

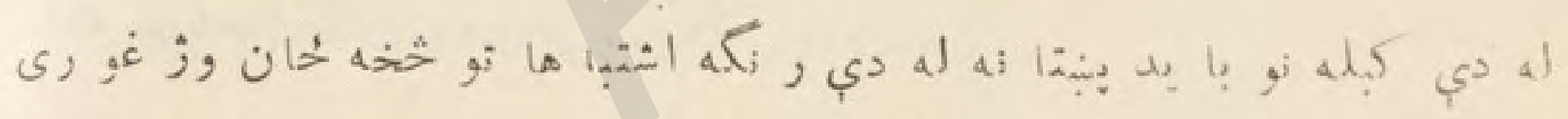

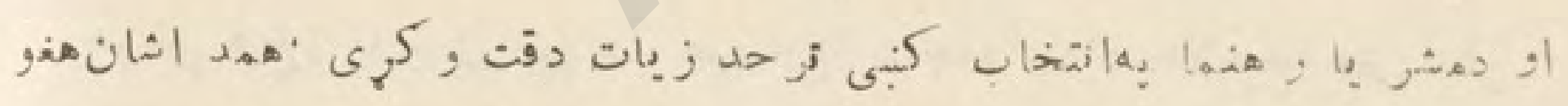

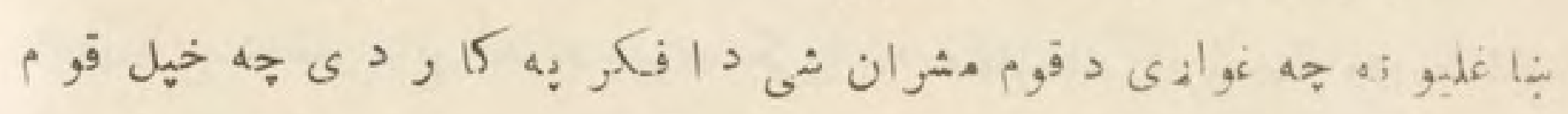

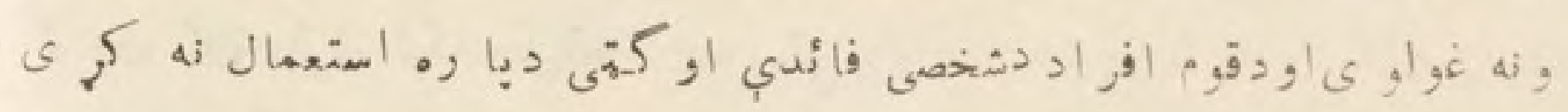

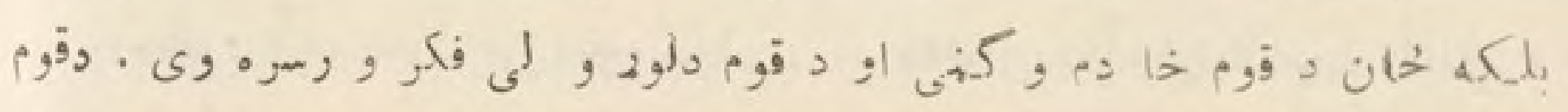

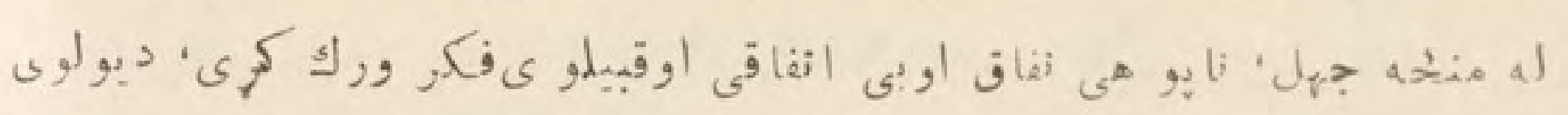

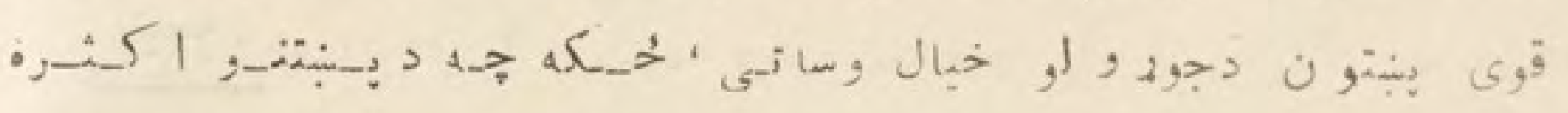

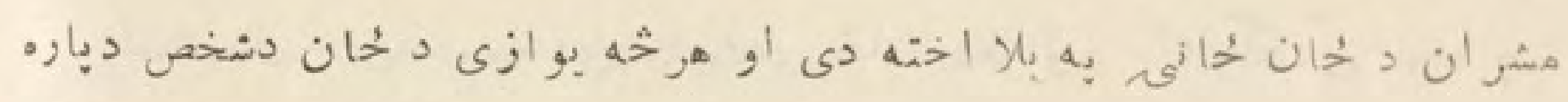

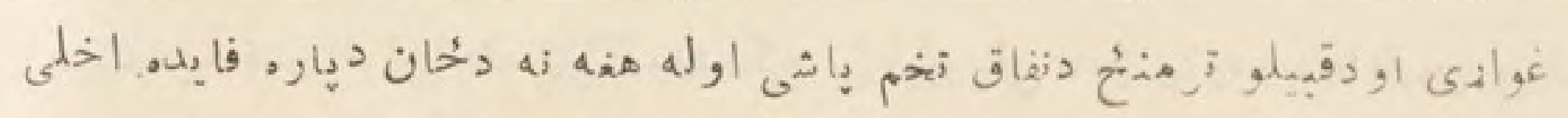


(r)

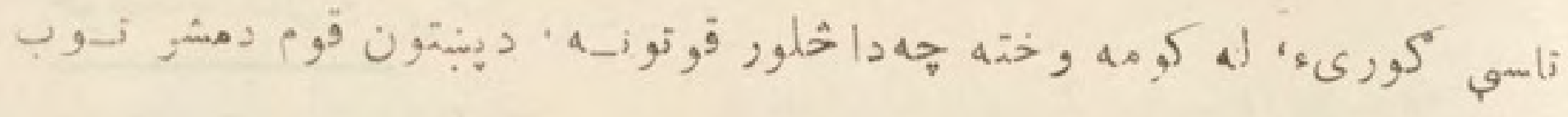

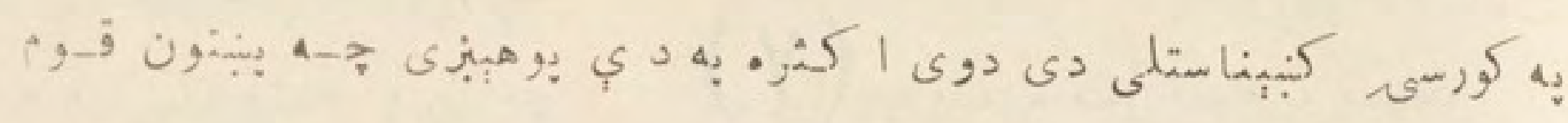

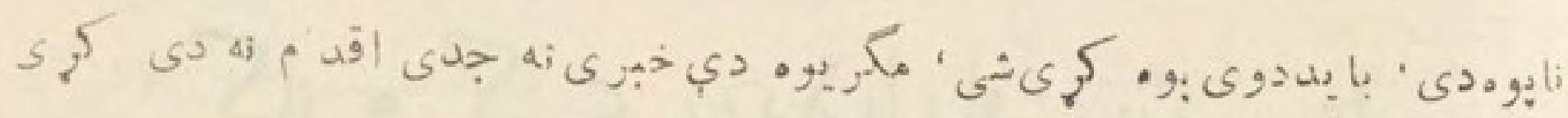

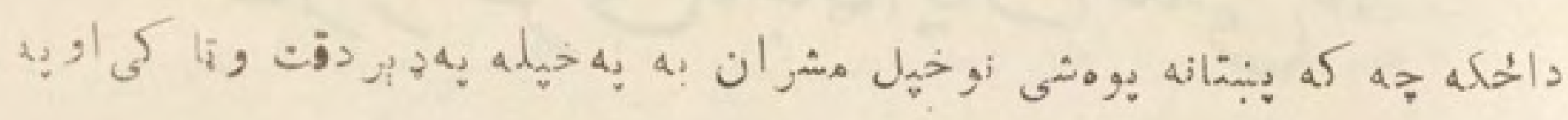

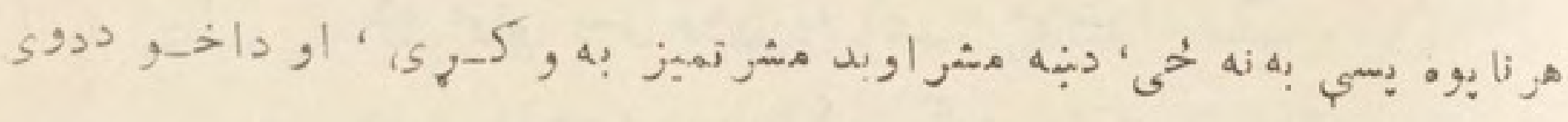

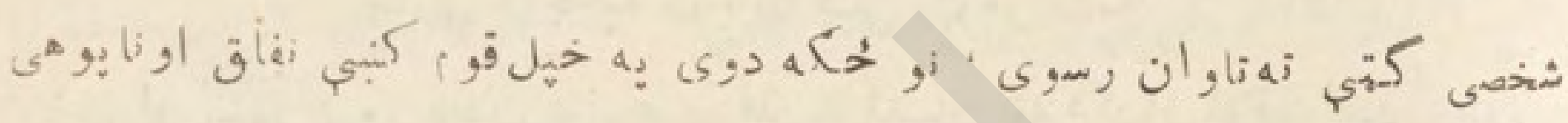

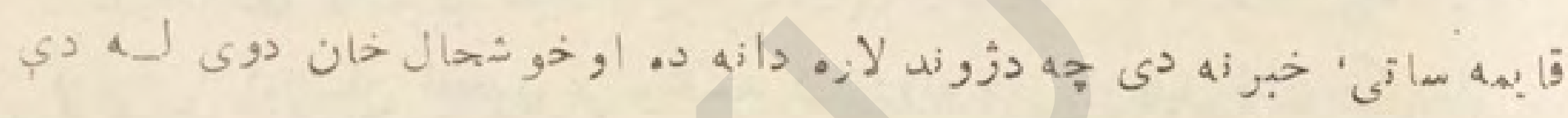

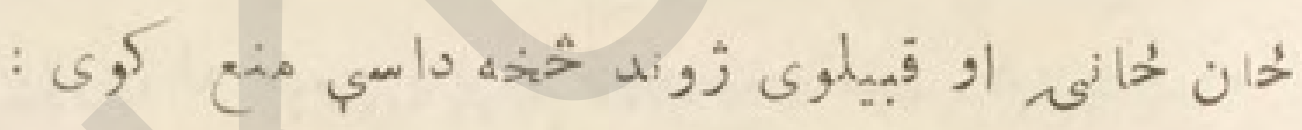

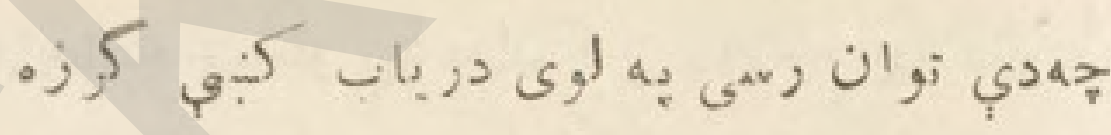

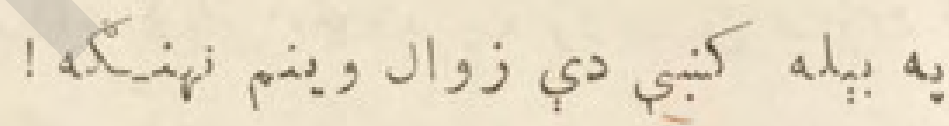


( $)$

$$
\text { خوشحان خان وابيى : }
$$

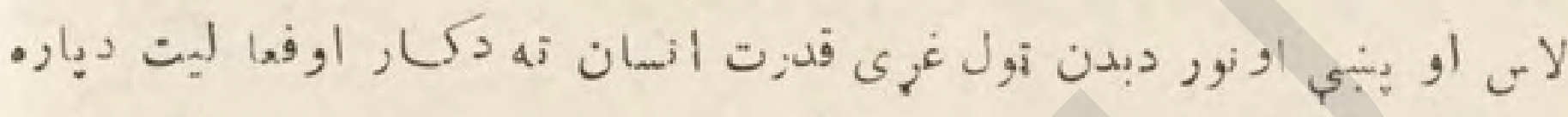

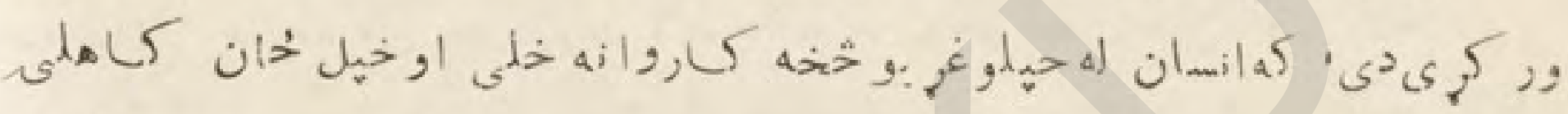

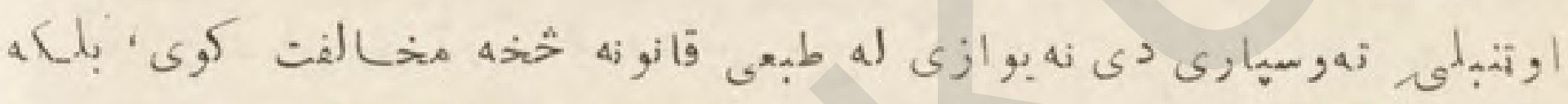

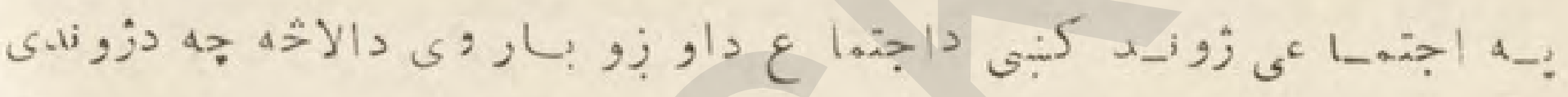

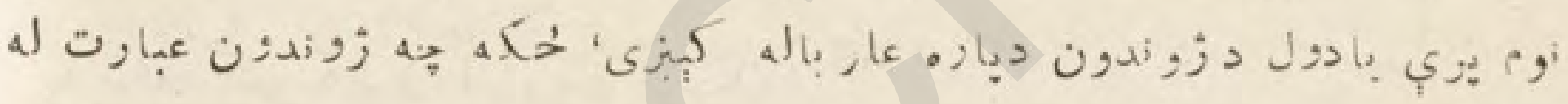

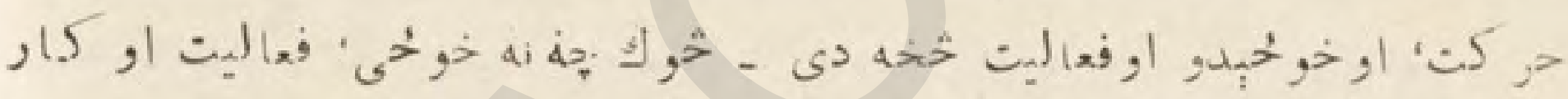

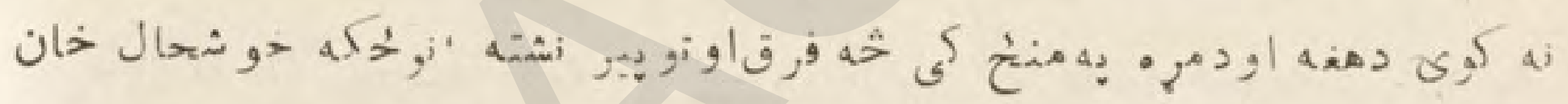

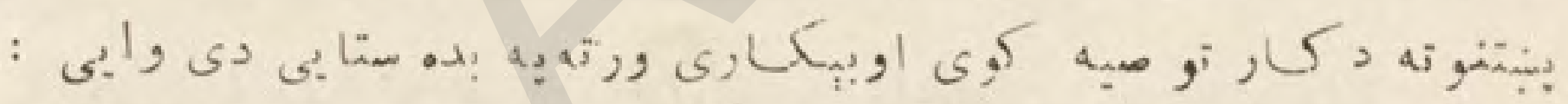

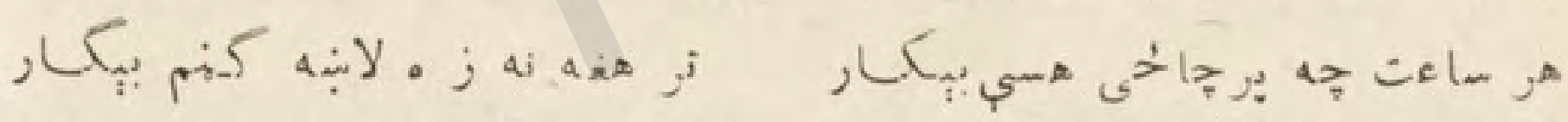

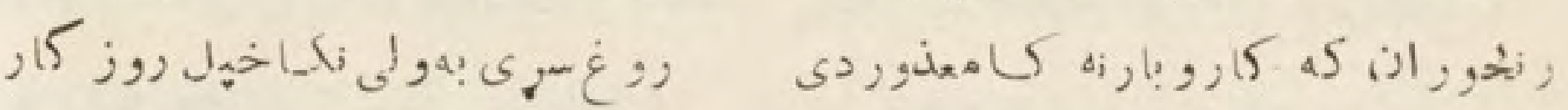

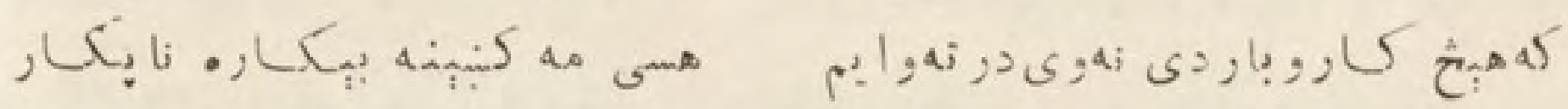

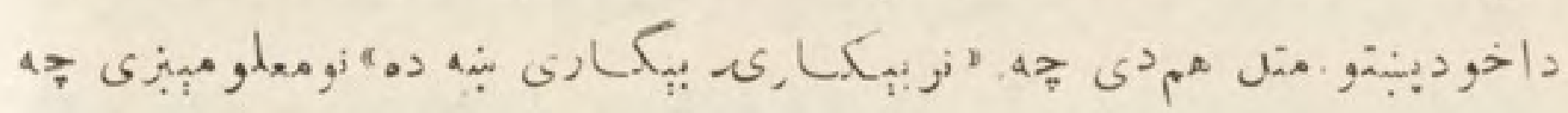

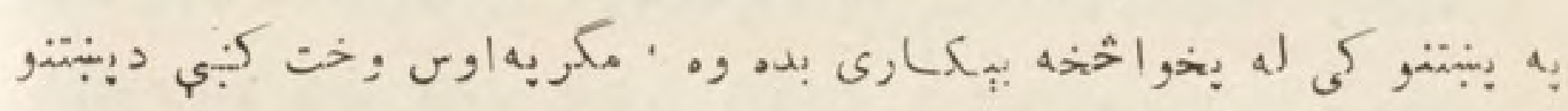

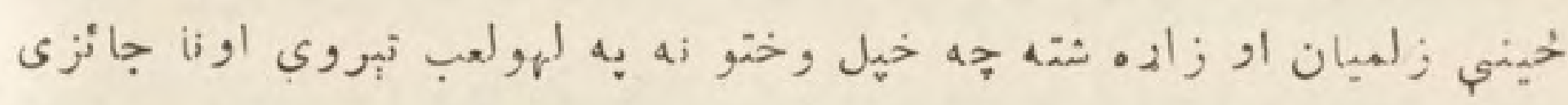

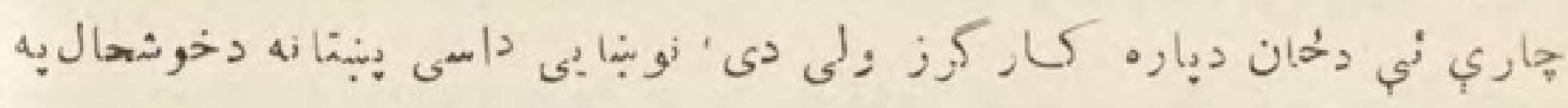

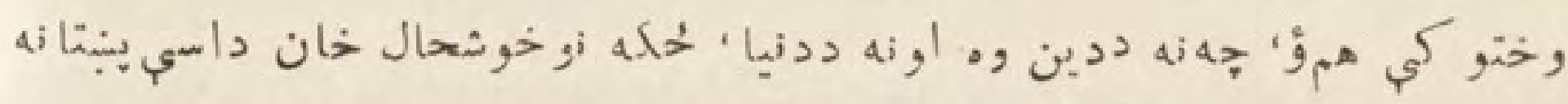

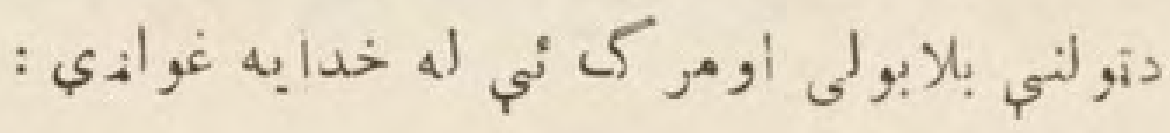




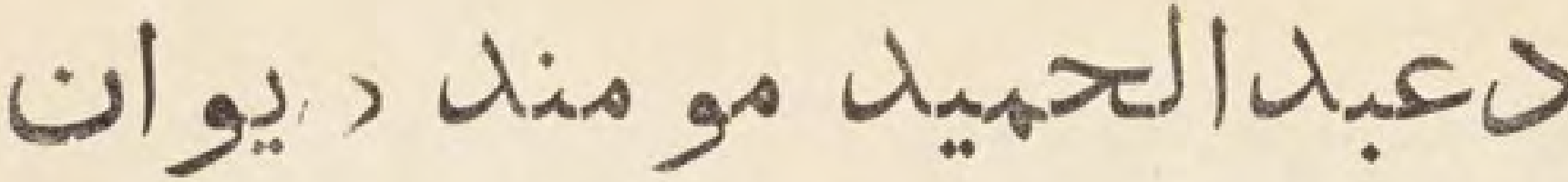

\section{$(\therefore, 9)$}

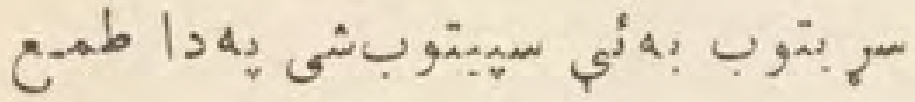

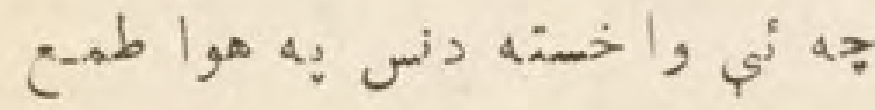

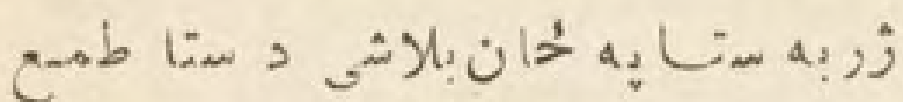

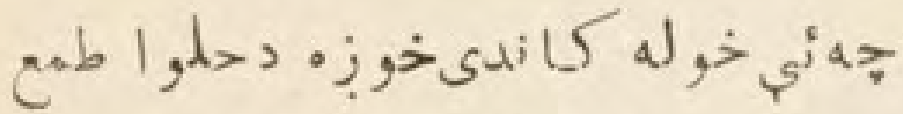

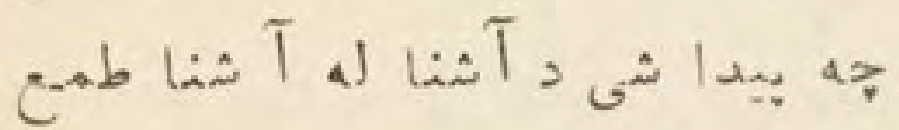

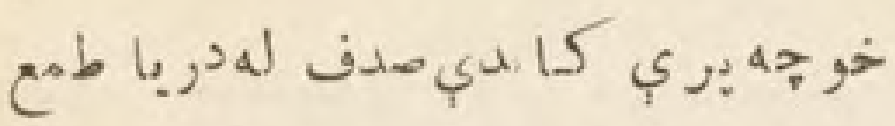

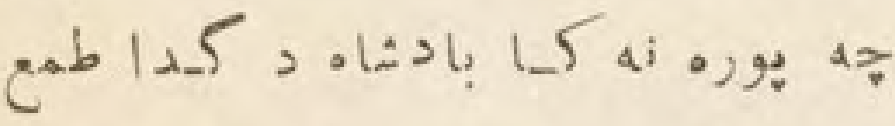

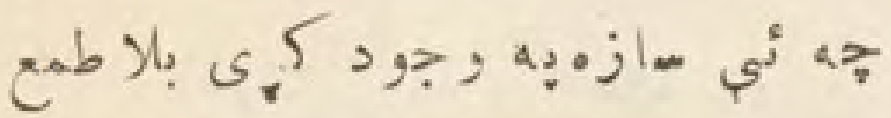

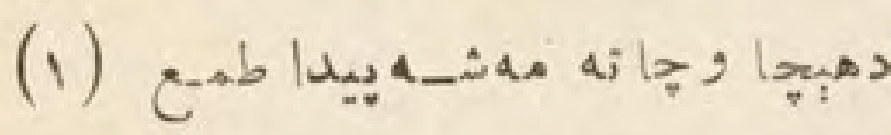

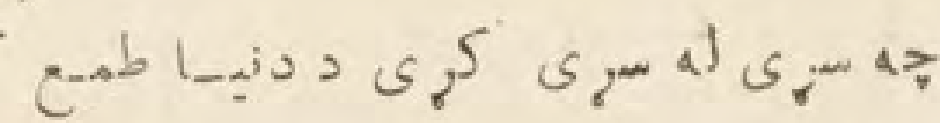

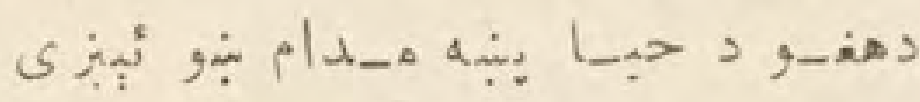

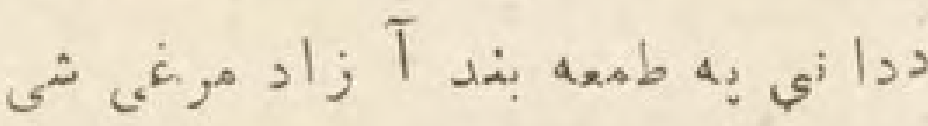

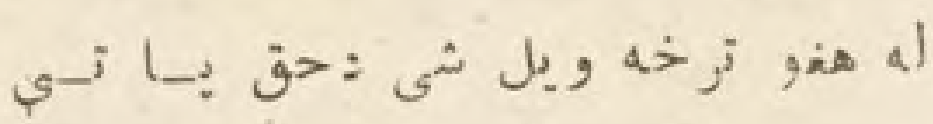

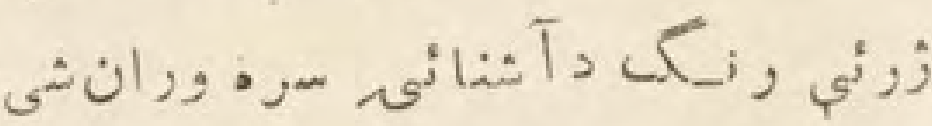

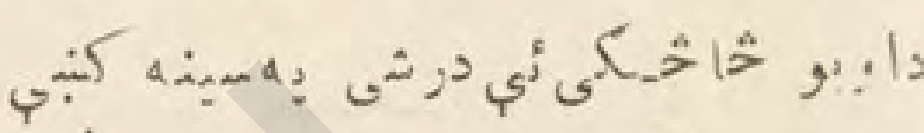

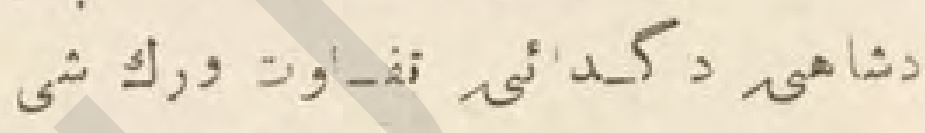

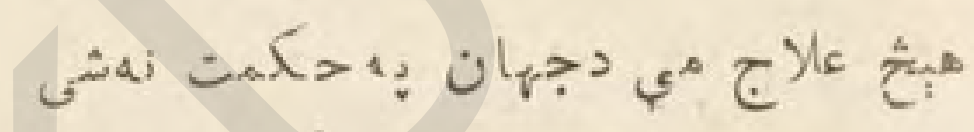

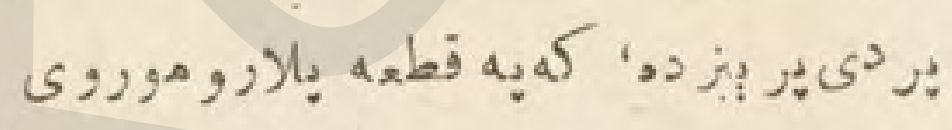

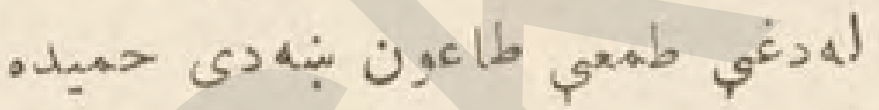

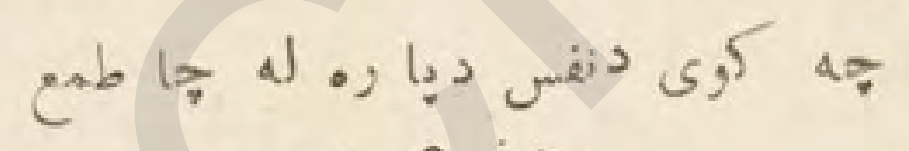
$\dot{\varepsilon} \dot{\varepsilon}$

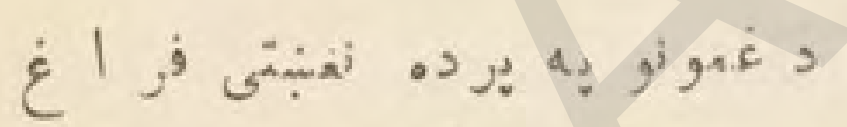

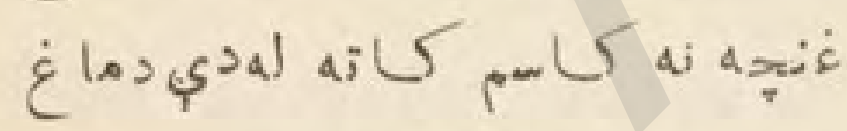

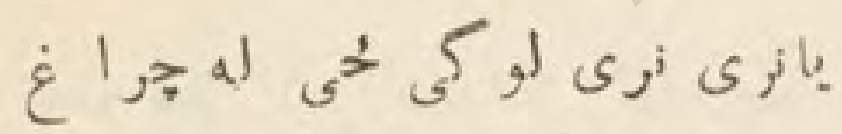

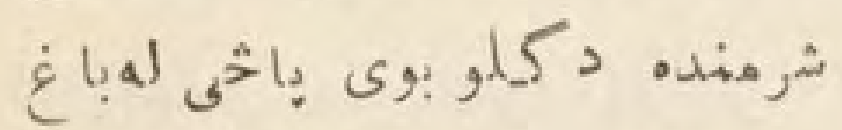

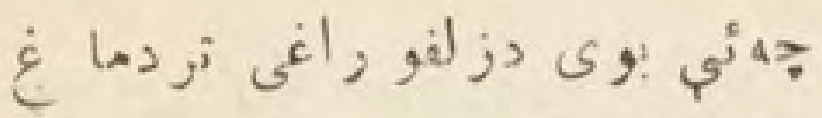

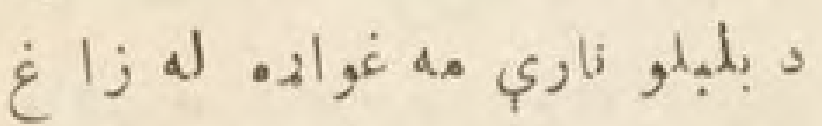
لكه

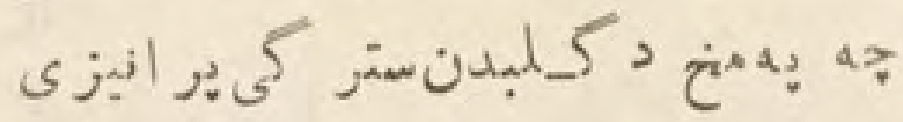

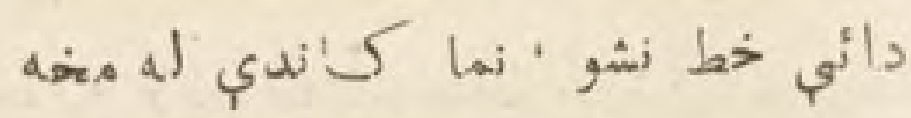
15

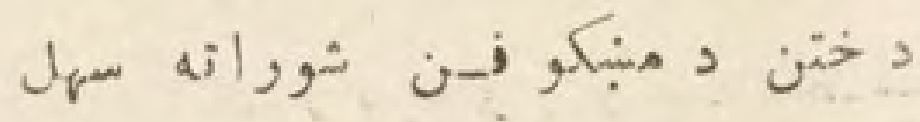

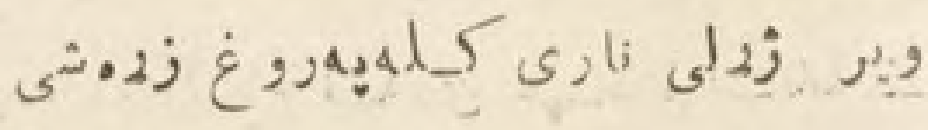

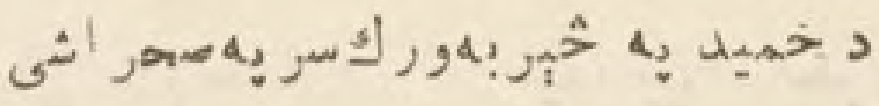

$$
\begin{aligned}
& \text { لخائل }
\end{aligned}
$$

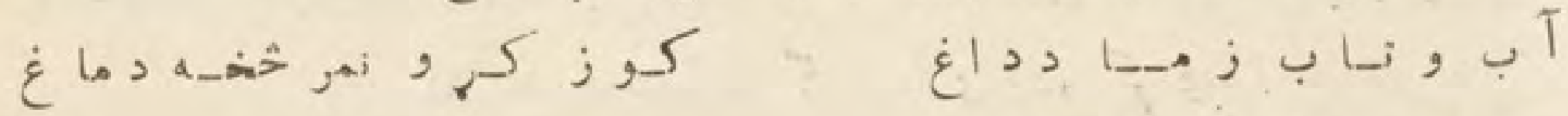

غ أنسا

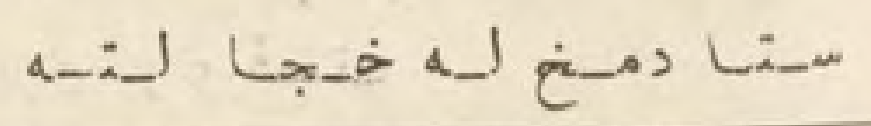

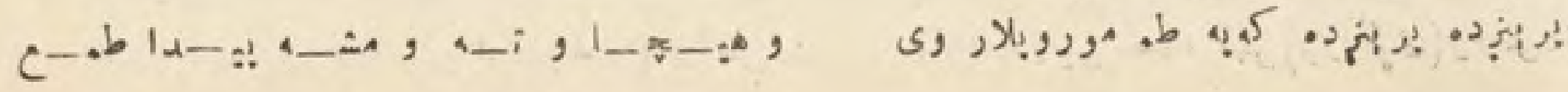




\section{$(r q)$}

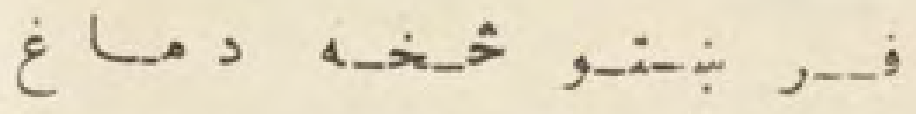

$$
\begin{aligned}
& \text { ورك كرو ستا بر إشا زمو ز لـفـو }
\end{aligned}
$$

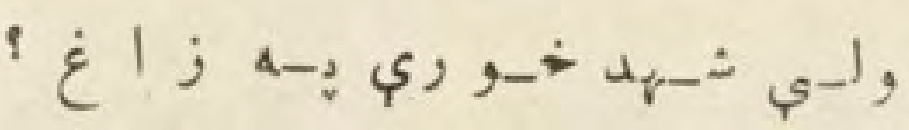

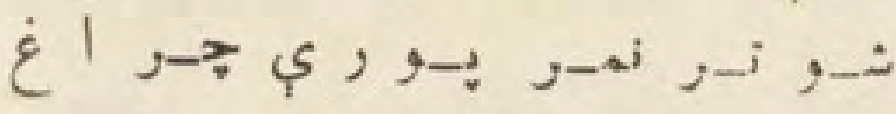

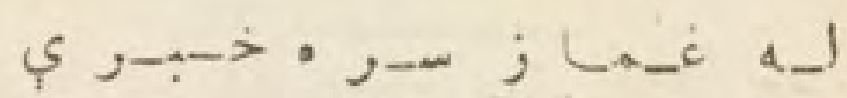

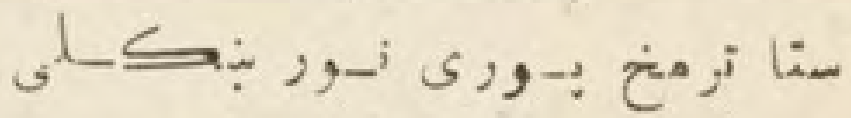

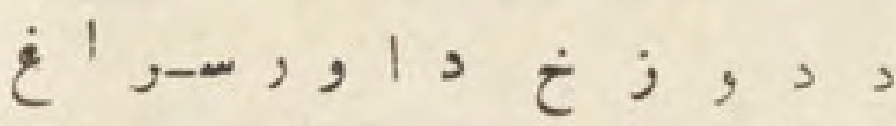

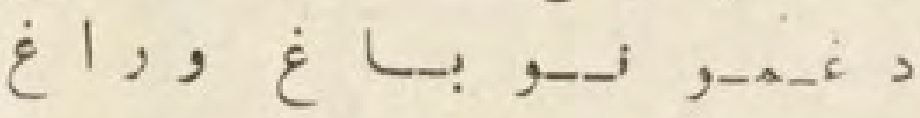

$$
\begin{aligned}
& \text { ص }
\end{aligned}
$$

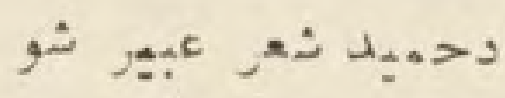

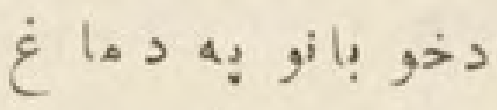

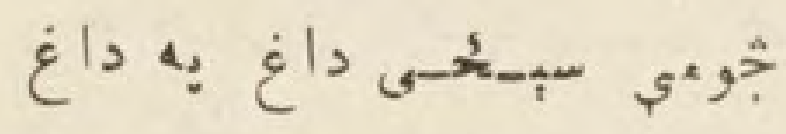

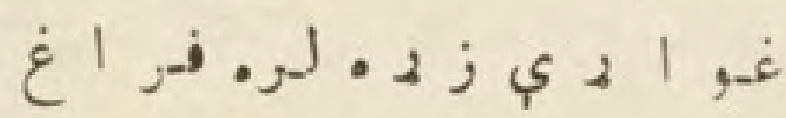

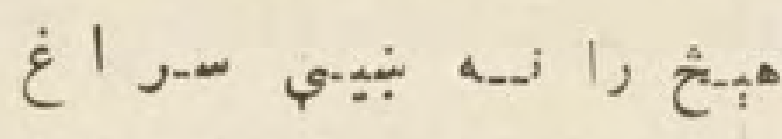

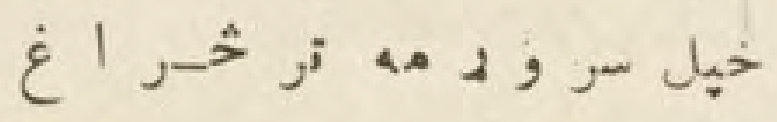

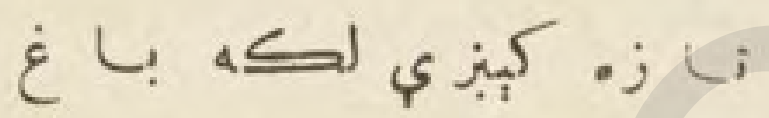

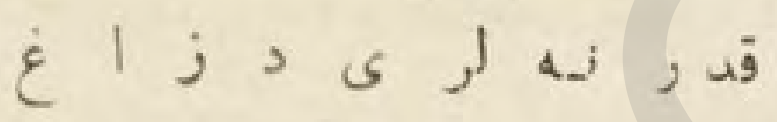

(1) (1)

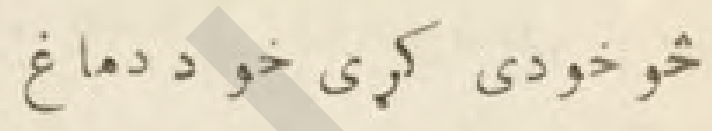

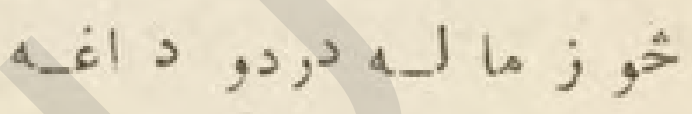

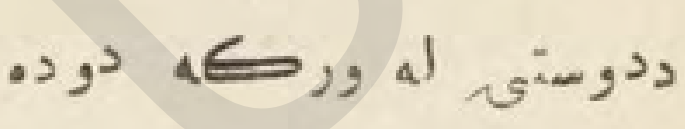

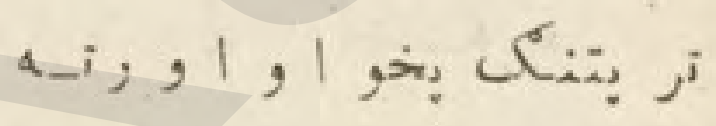

Ai

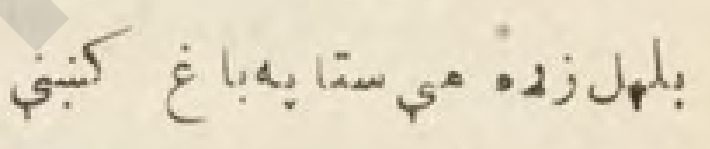
\&

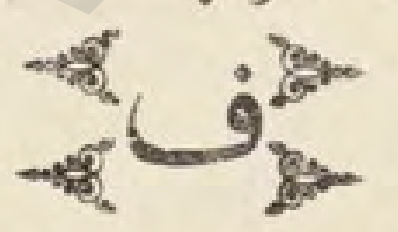

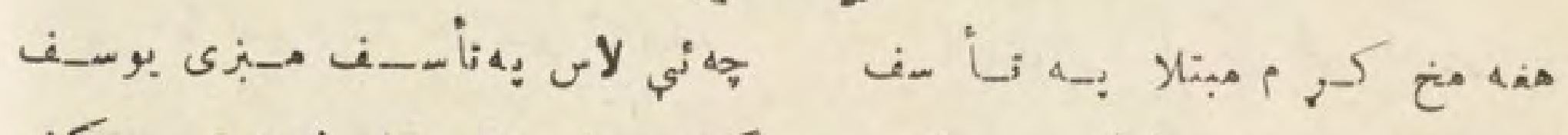

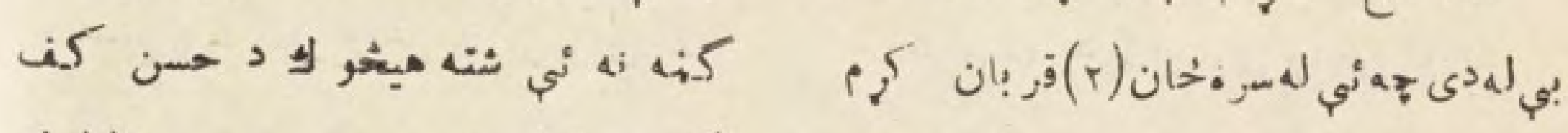

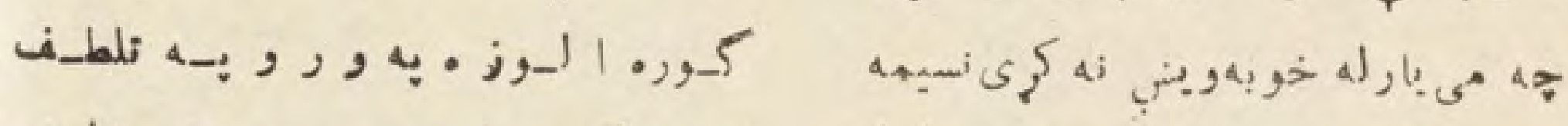

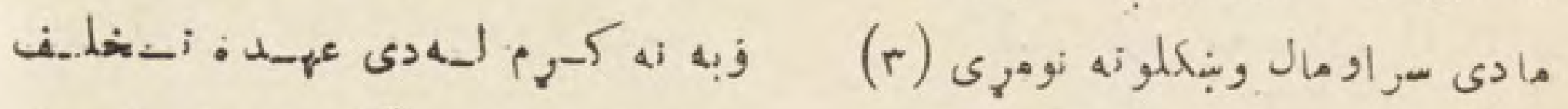

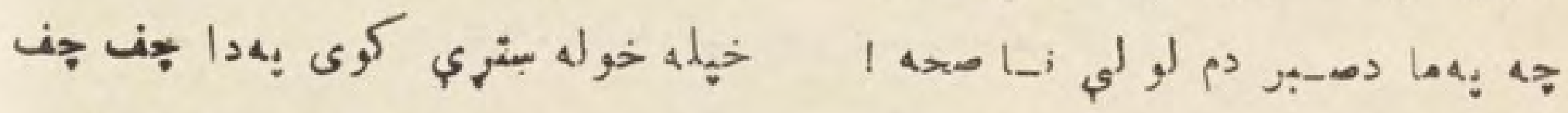

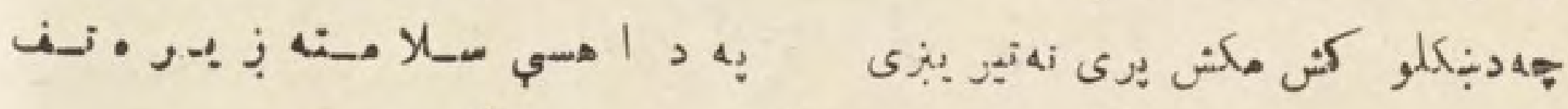
ى كي

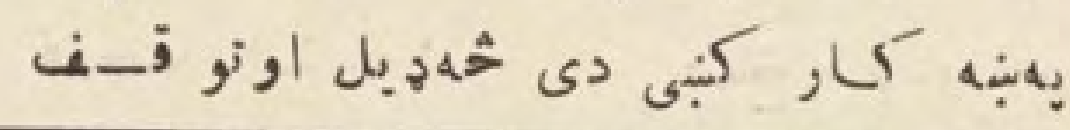

(1)

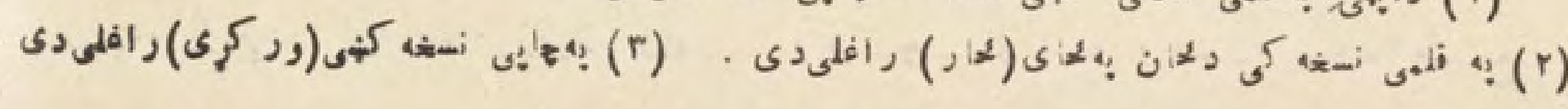




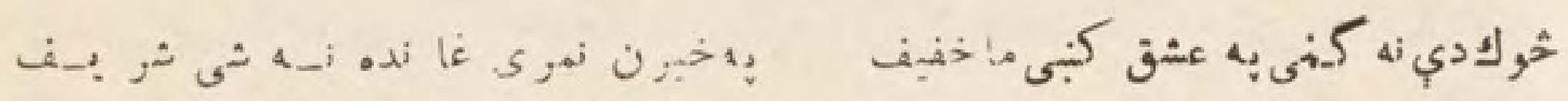

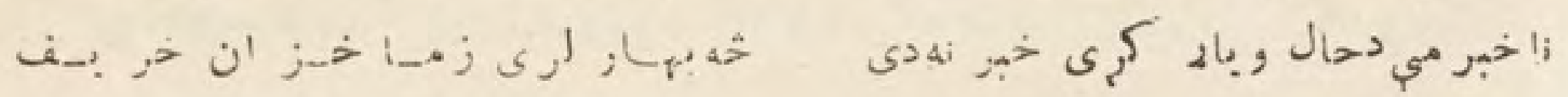

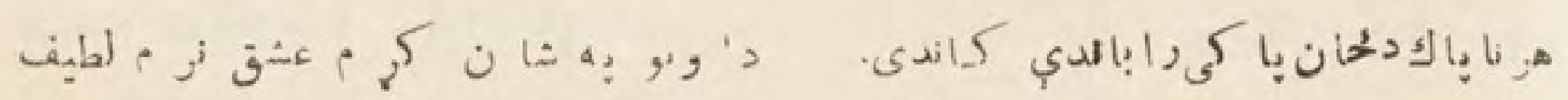

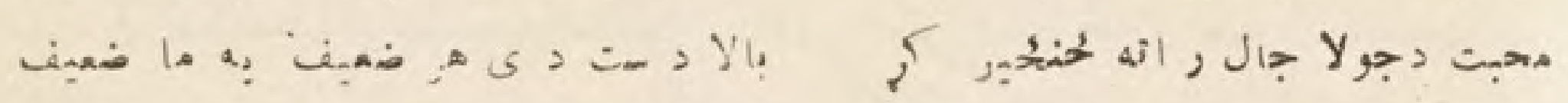

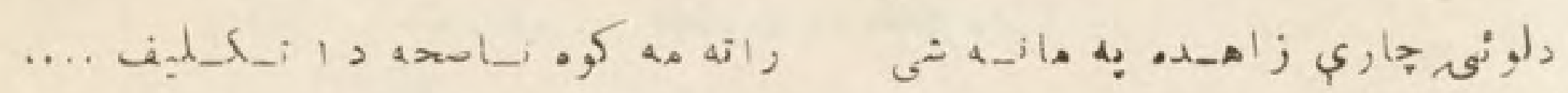

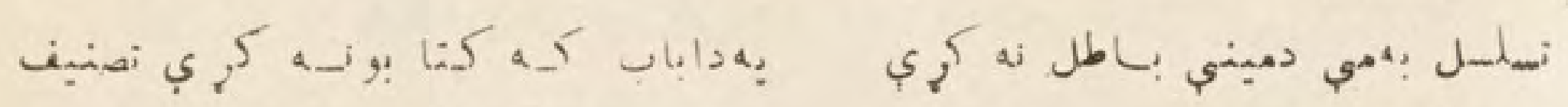

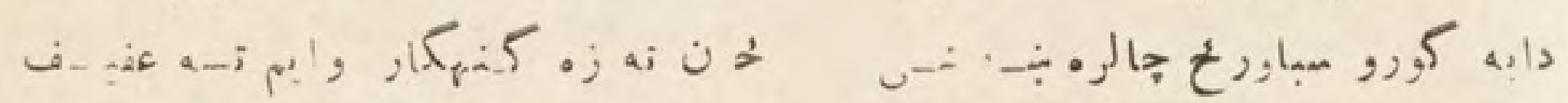

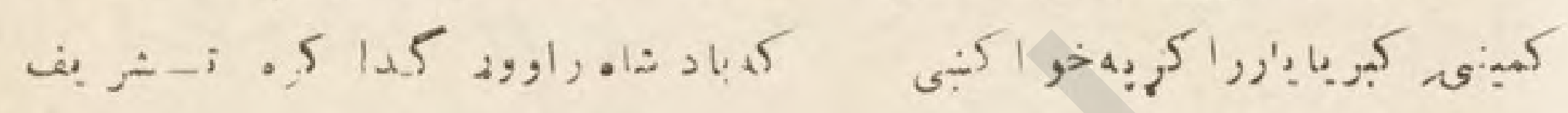

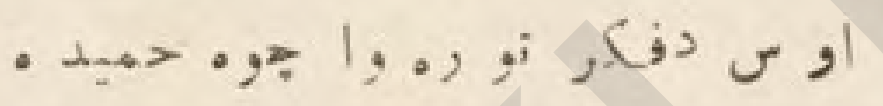

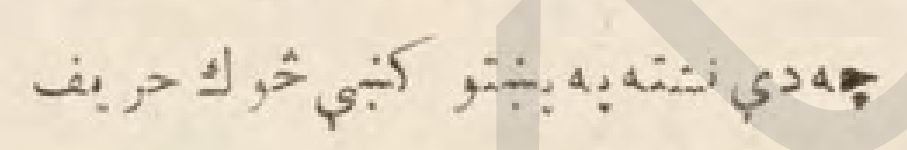

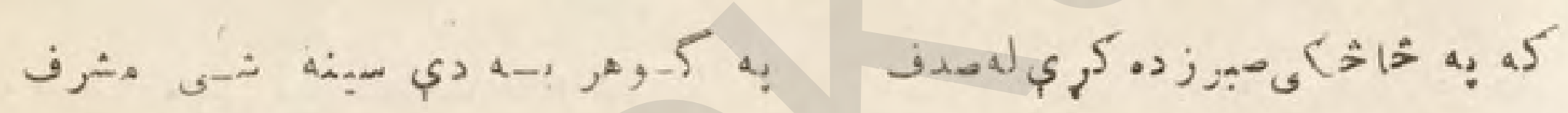

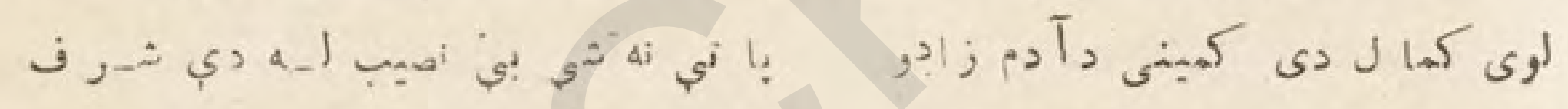

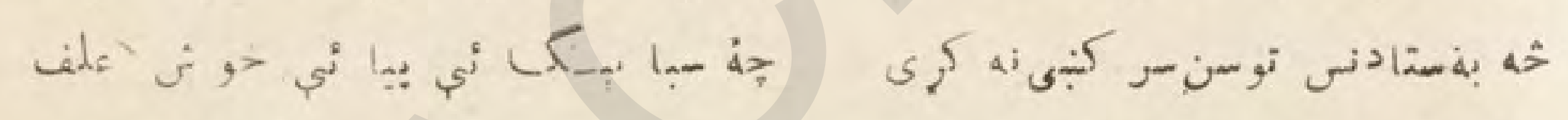

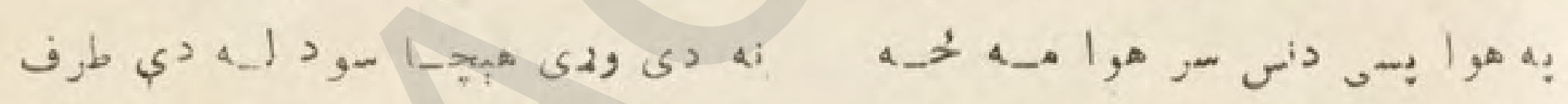

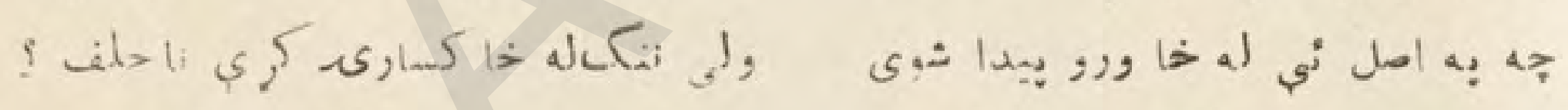

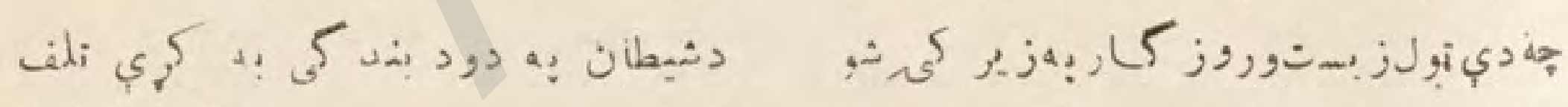
(1)

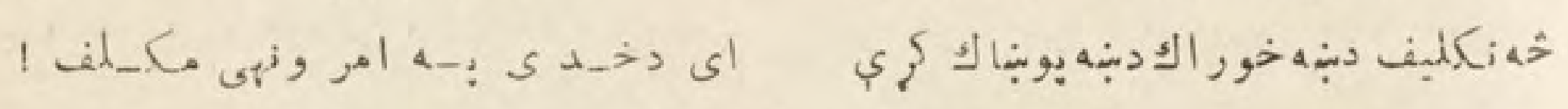

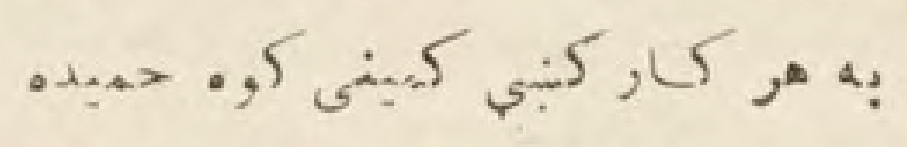

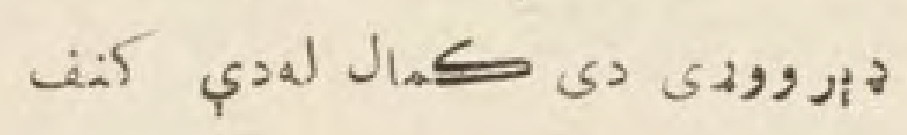

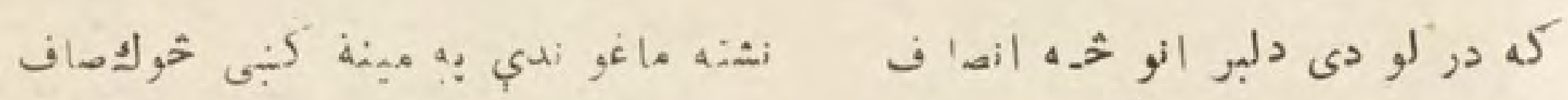

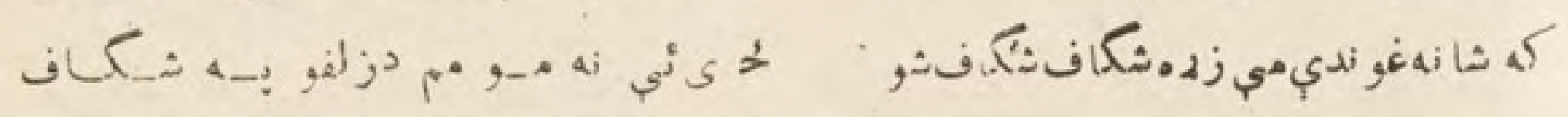

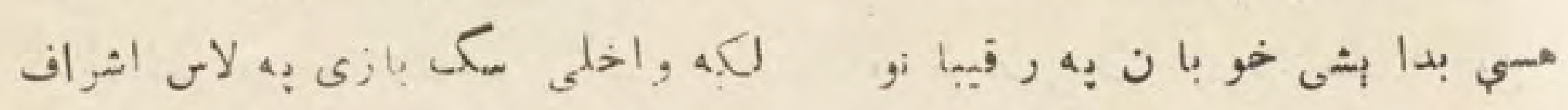

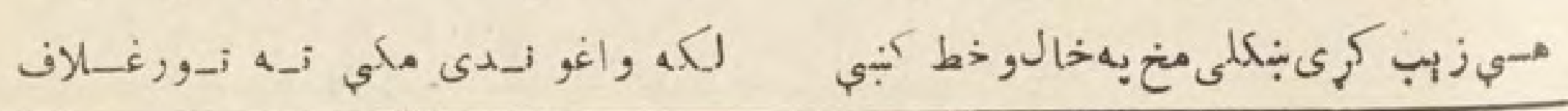




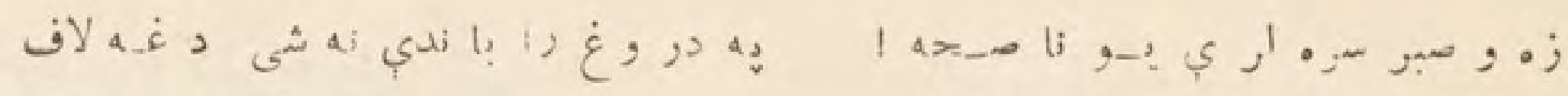

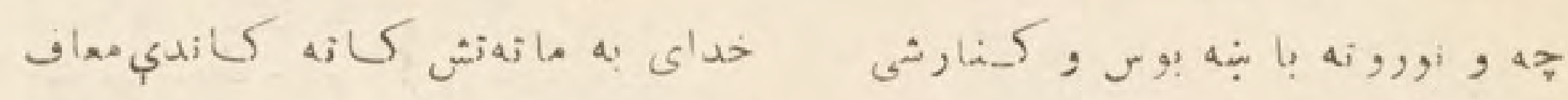

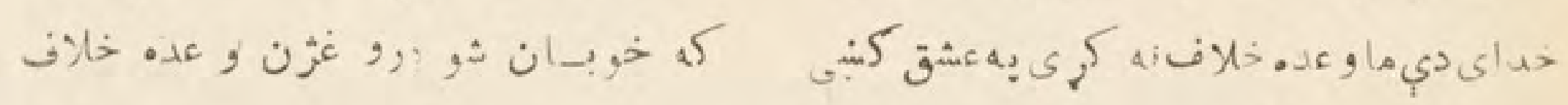

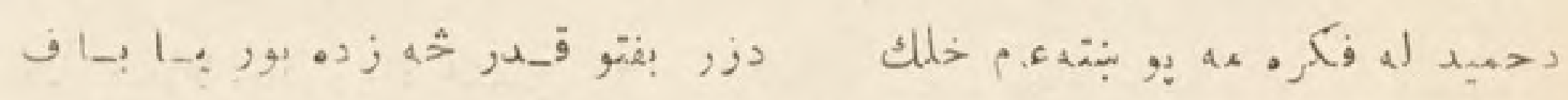

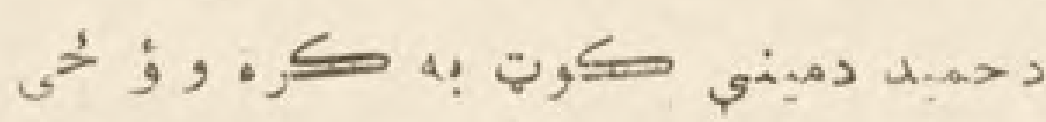

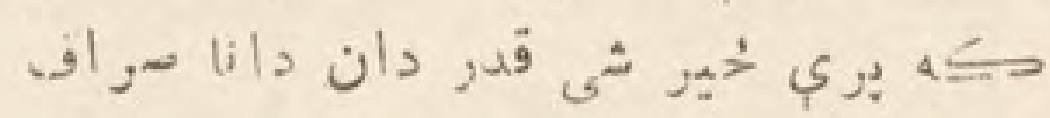

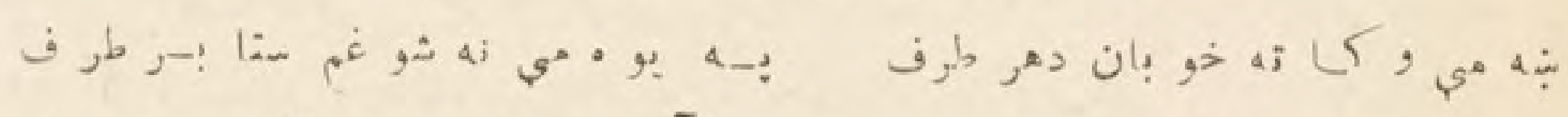

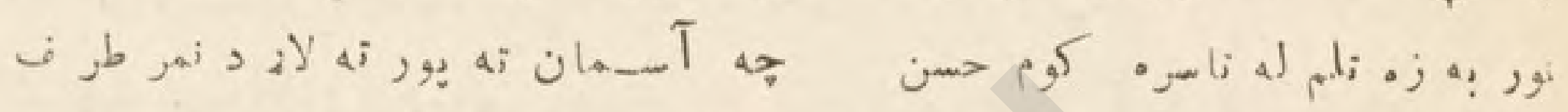

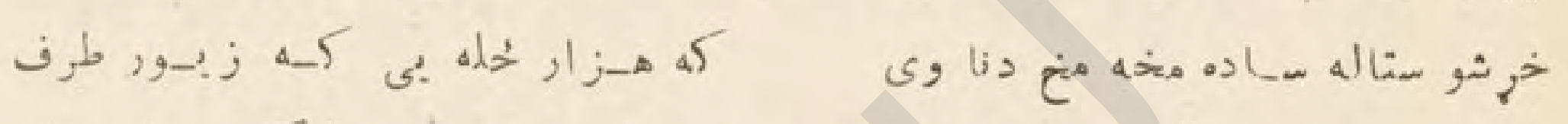

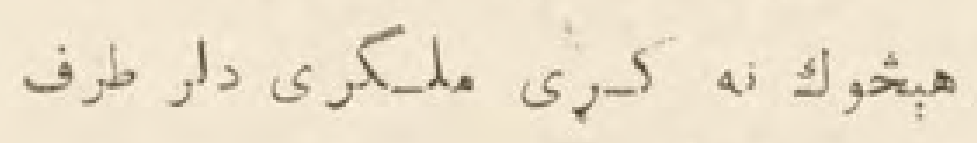

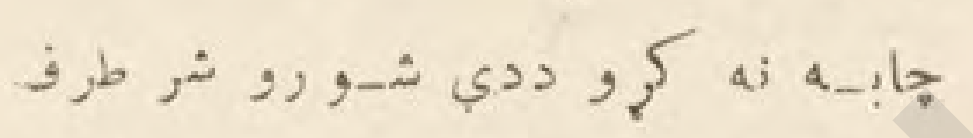

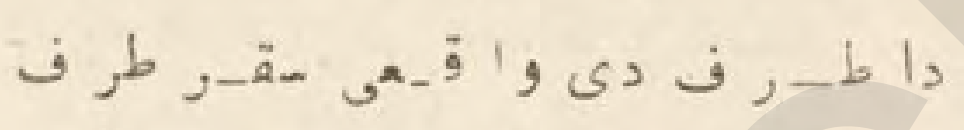

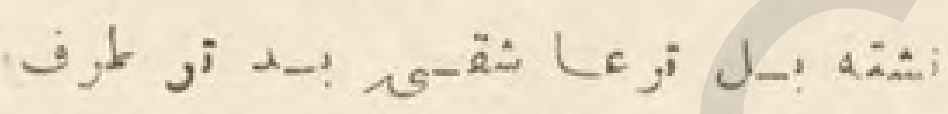

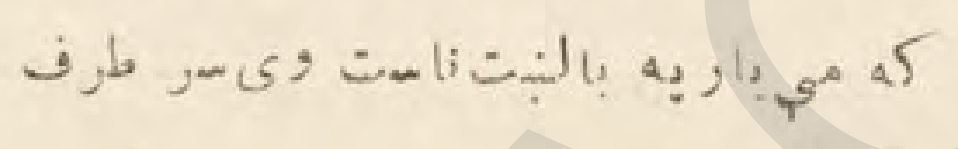

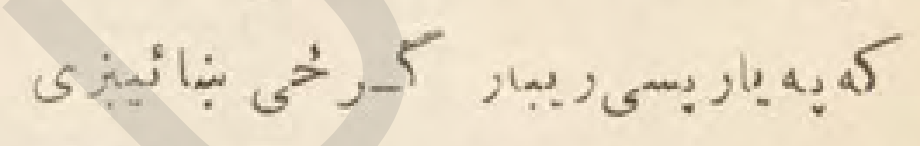

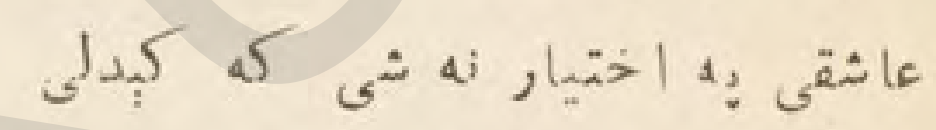

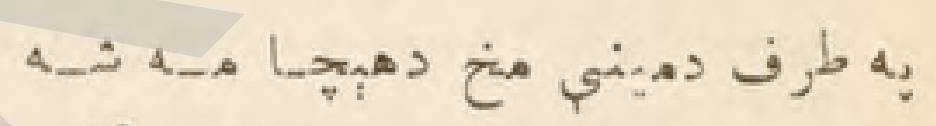

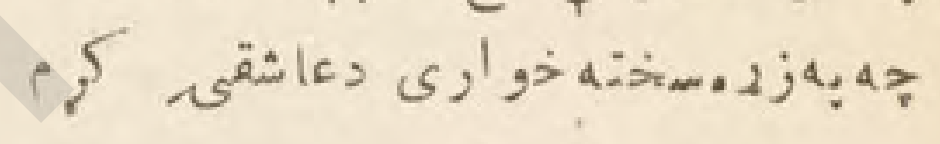
هت̈;

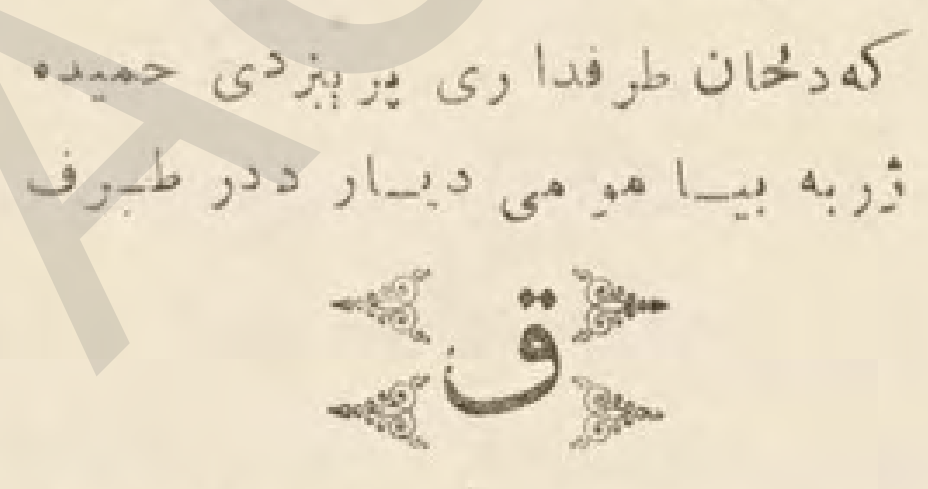

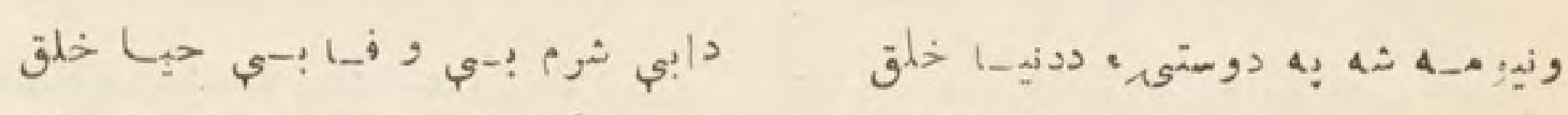

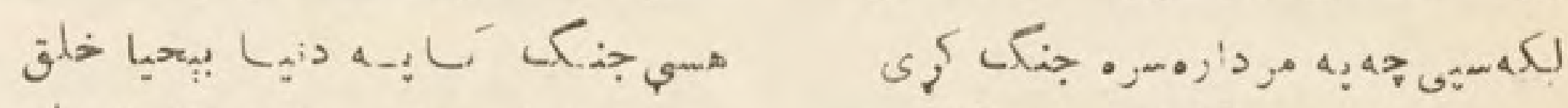

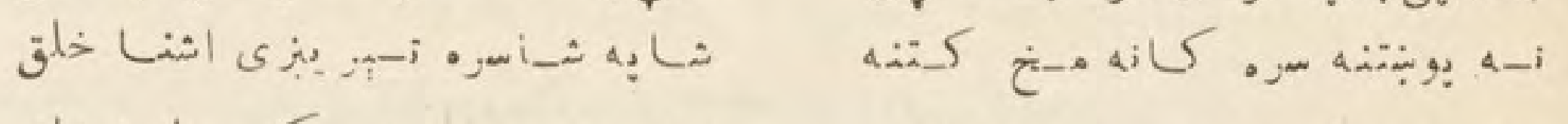

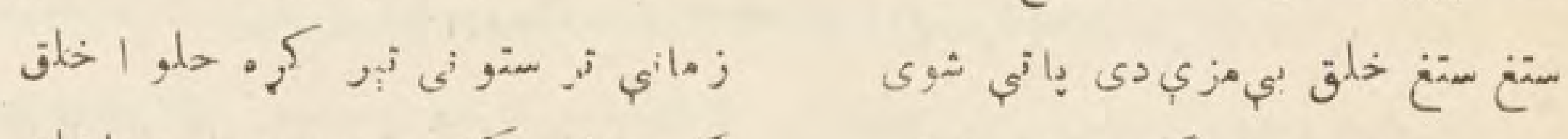

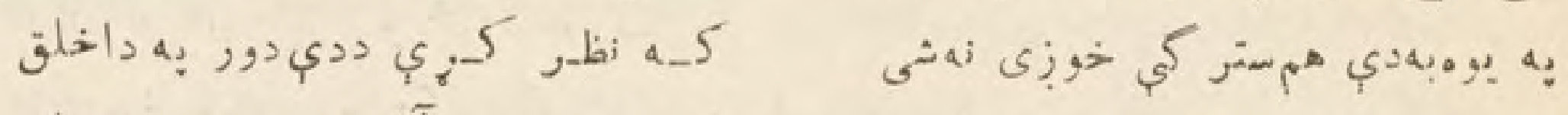

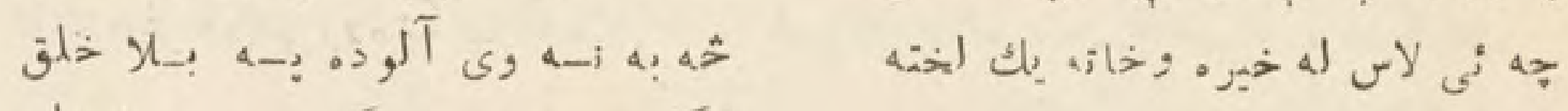

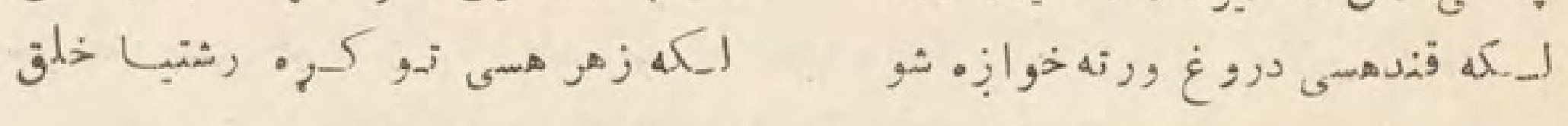

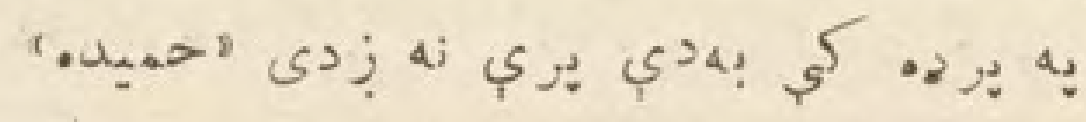

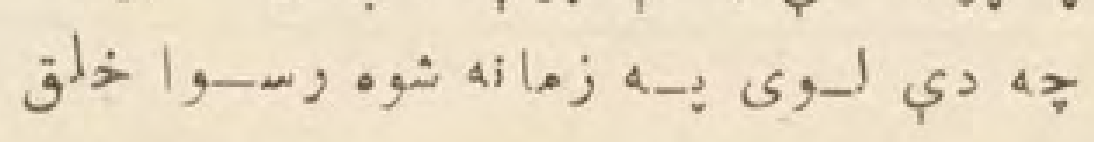




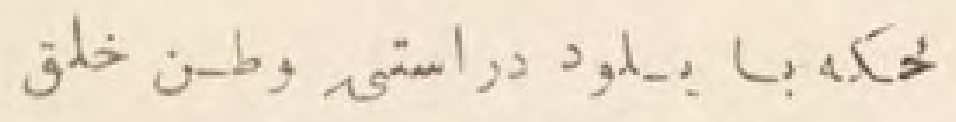

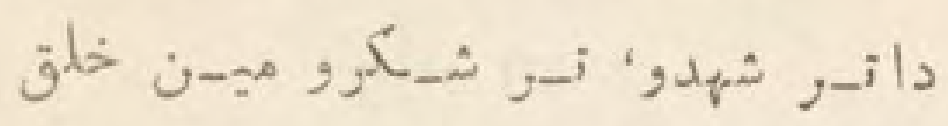

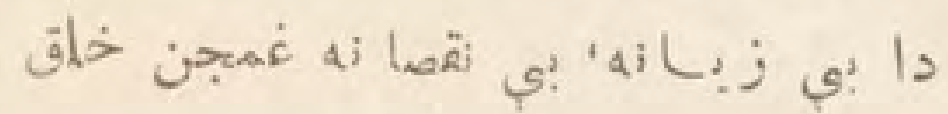

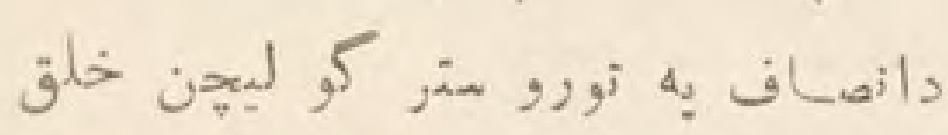

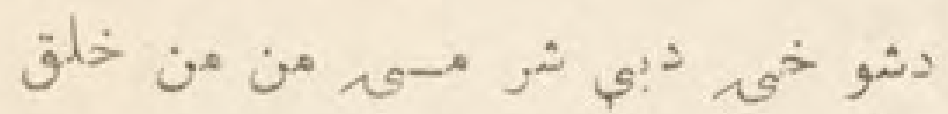

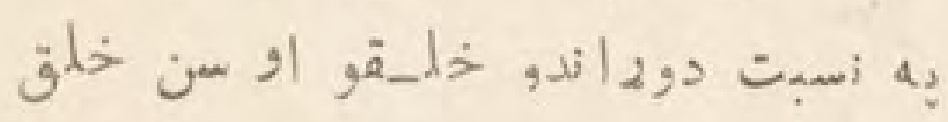

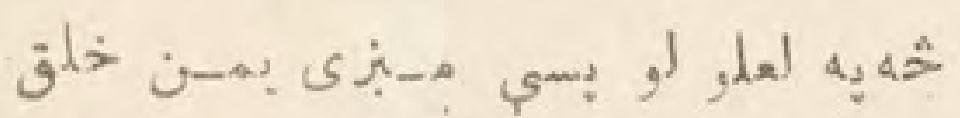

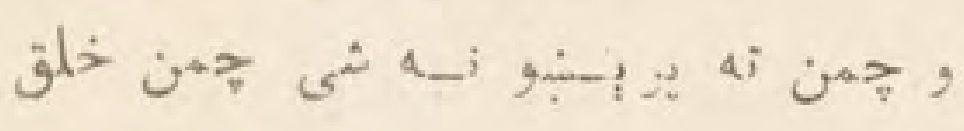

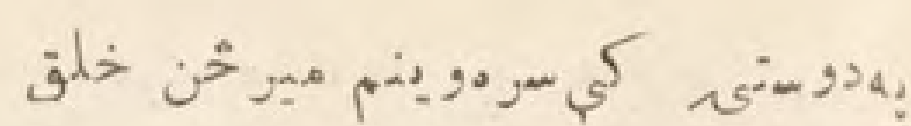

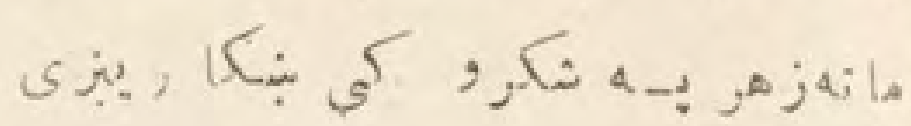

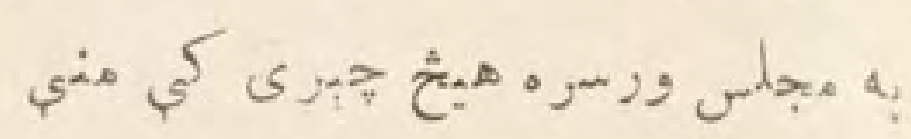

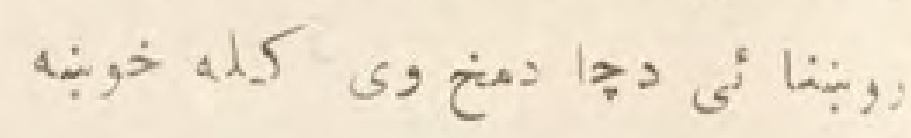

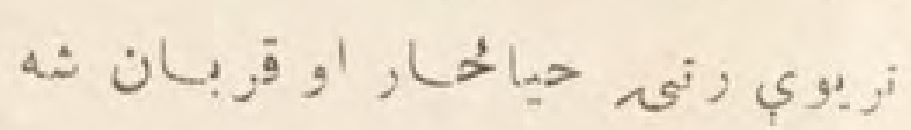

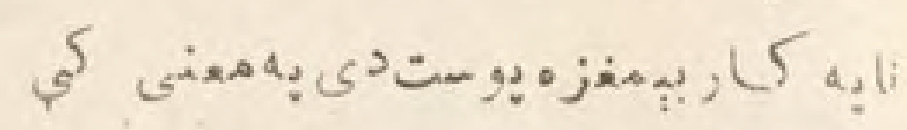

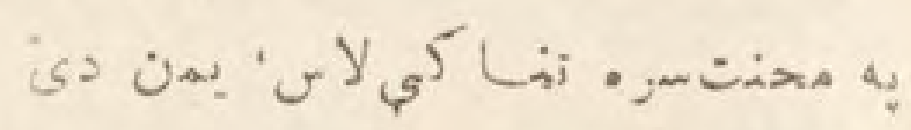

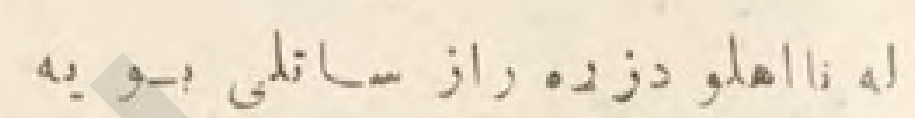

$$
\begin{aligned}
& \text { ر غو }
\end{aligned}
$$

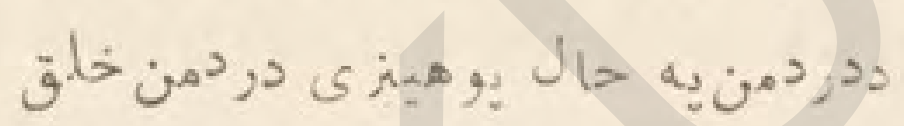

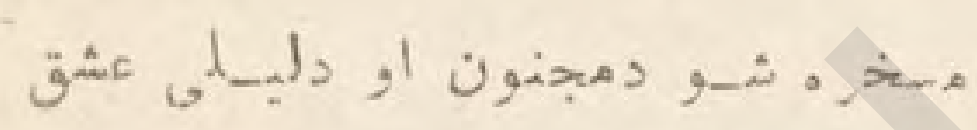

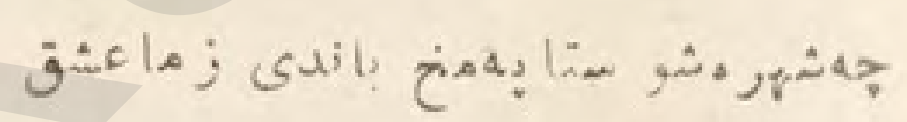

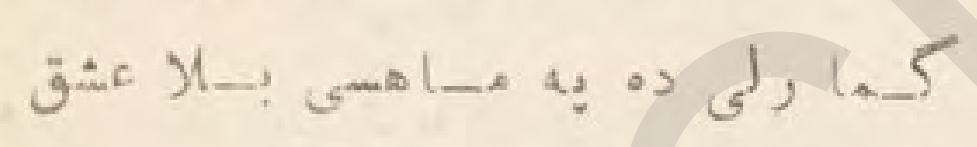
جهarar

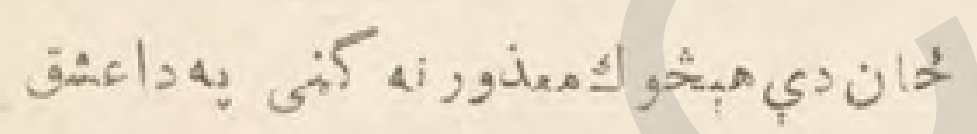

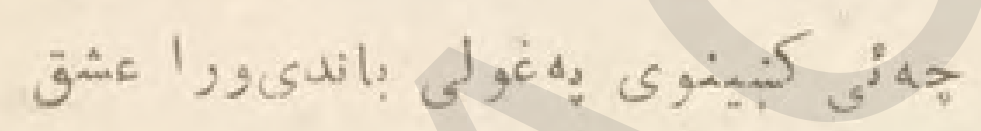

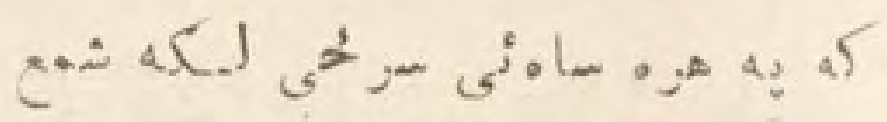

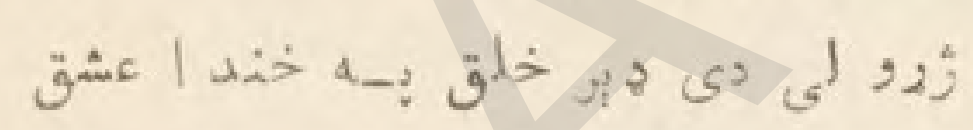

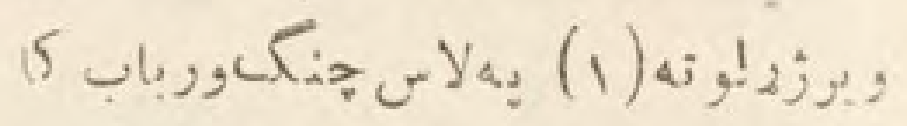

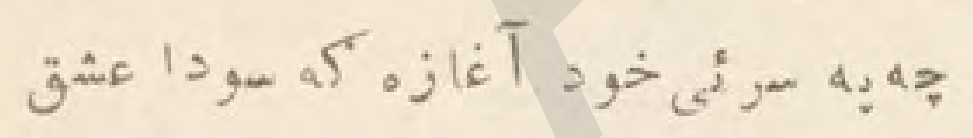

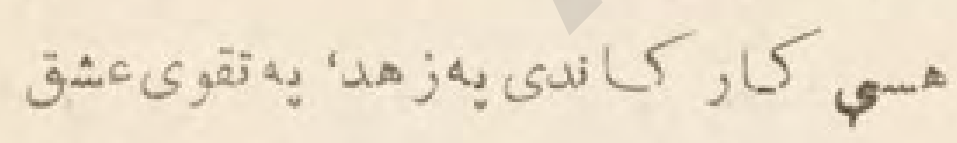

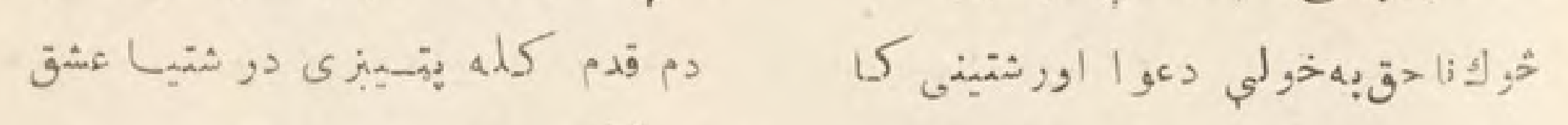

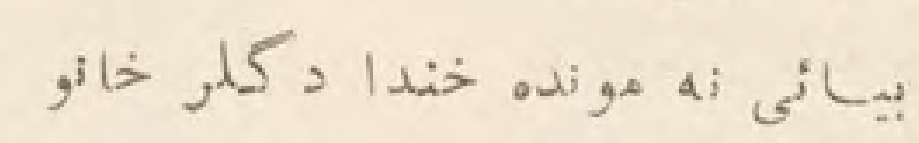

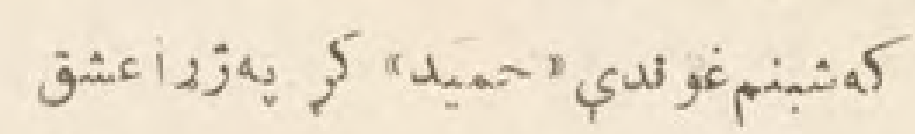

عـا شقان ;اخت , زار اجنهر الرى شوق

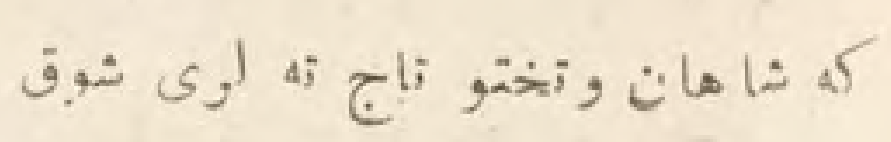

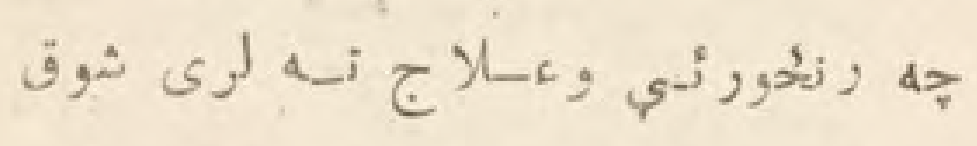

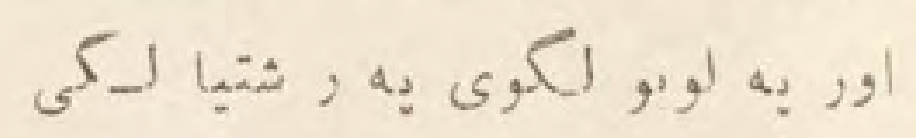

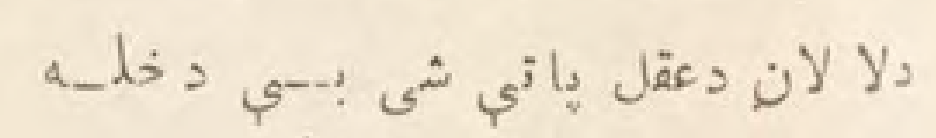

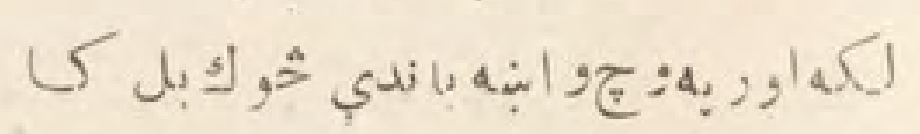

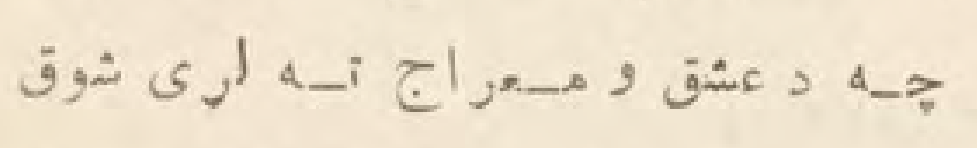

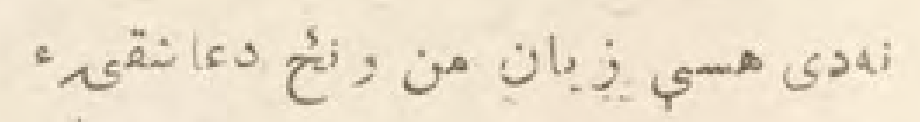

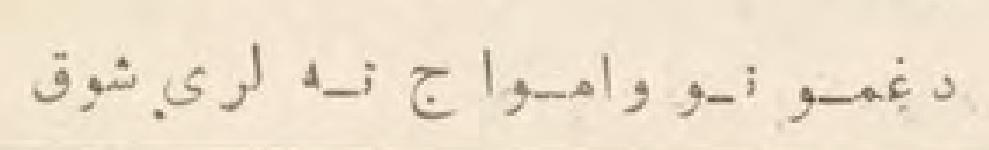

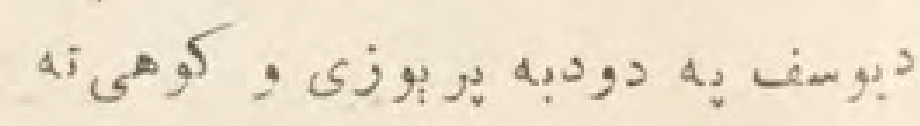

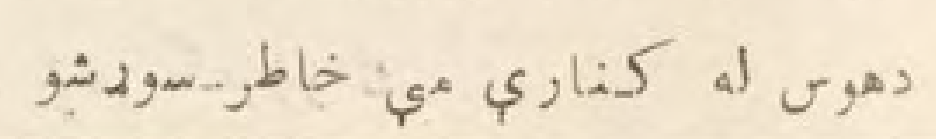
. ज 1 (1) 
جه

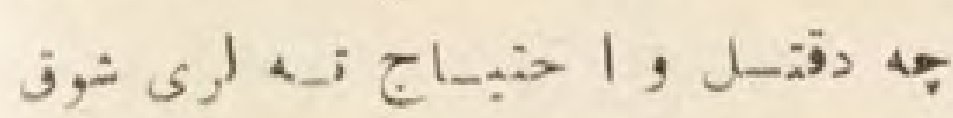

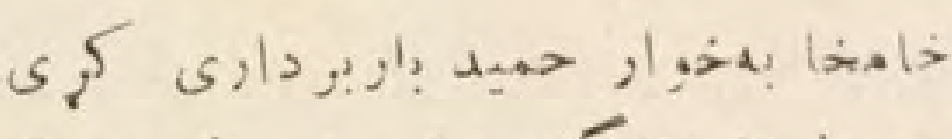

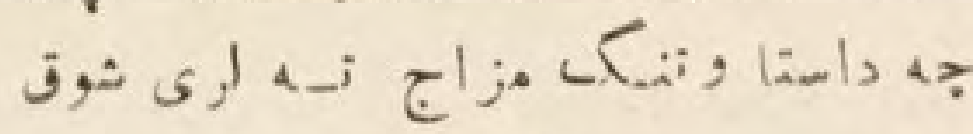

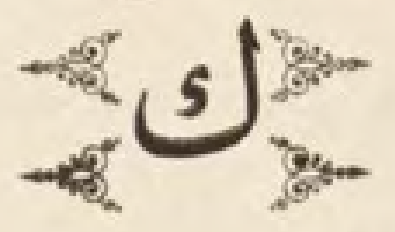

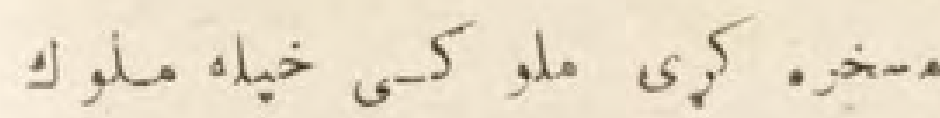

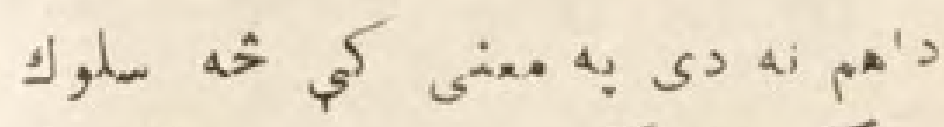

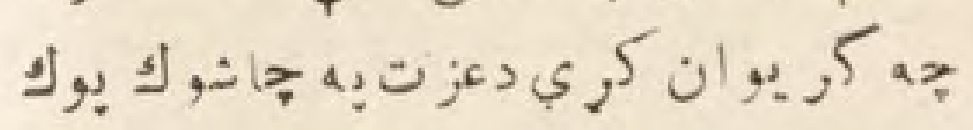

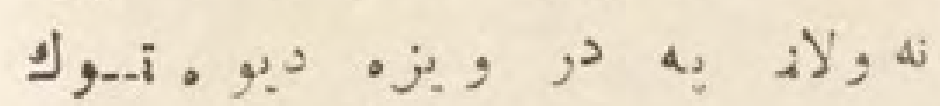

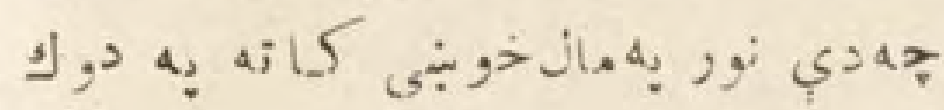

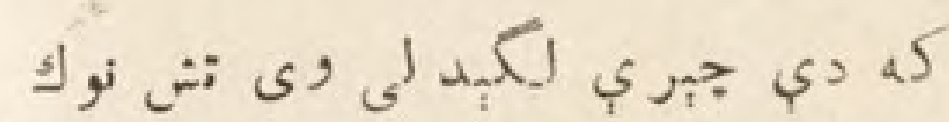
(1) (1) جه

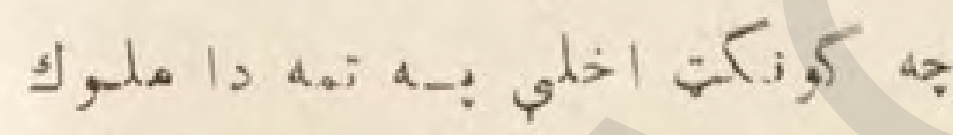

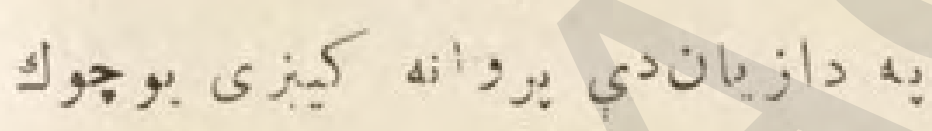

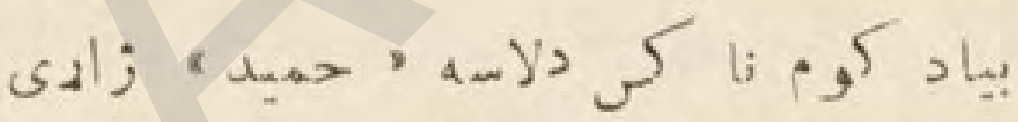

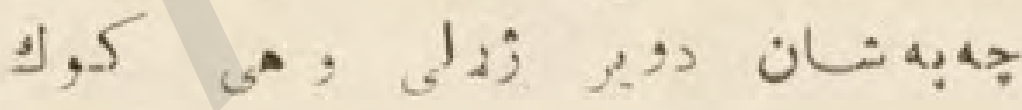

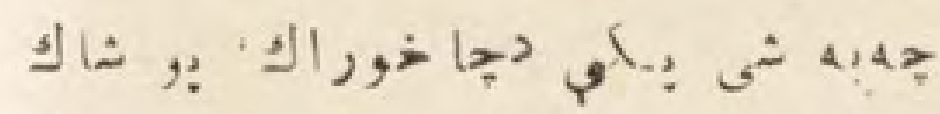

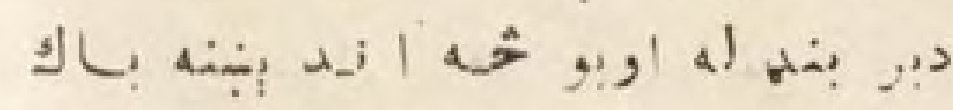
به إنهان

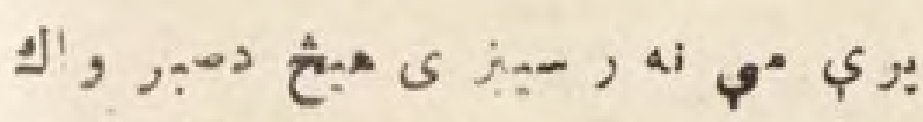

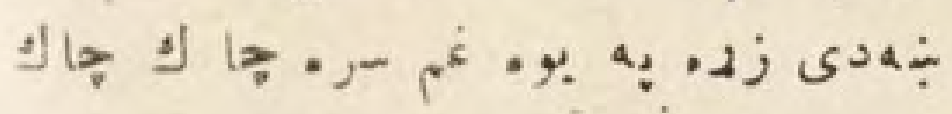

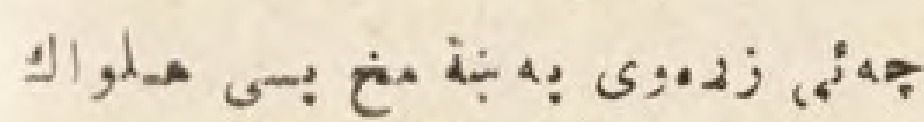

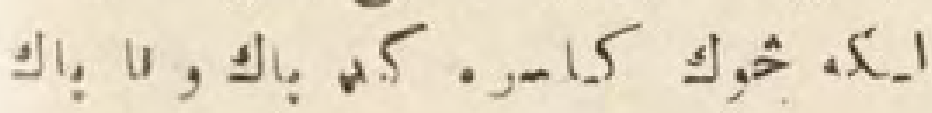

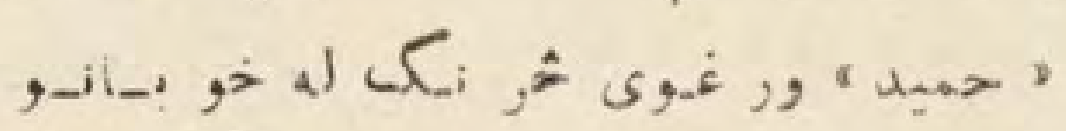

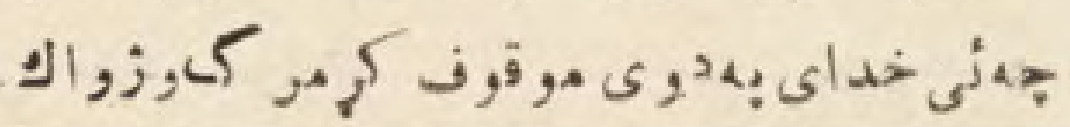

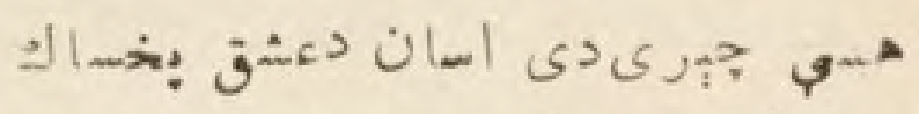
a

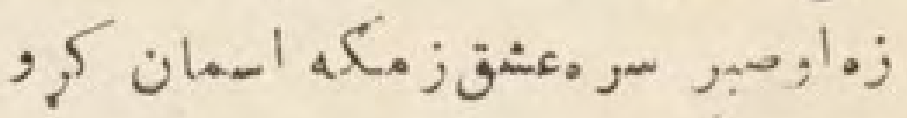

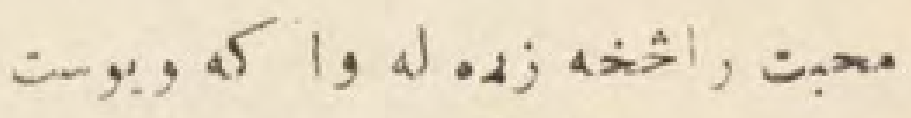

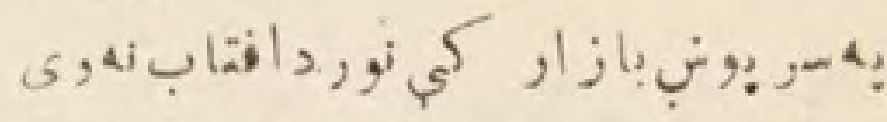

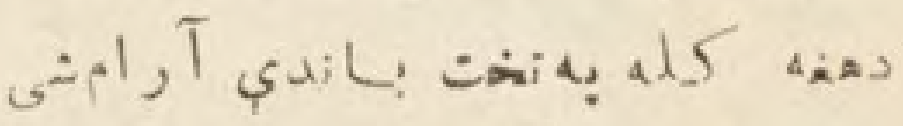

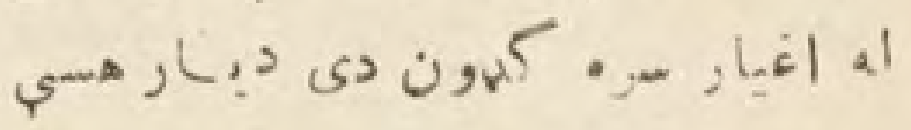

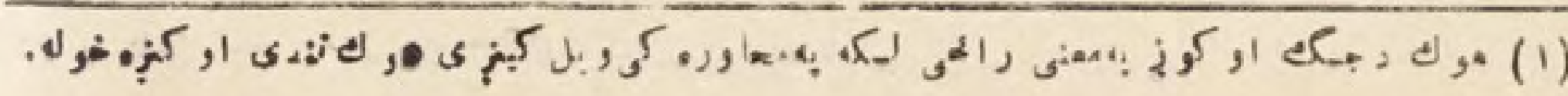




\section{(ra)}

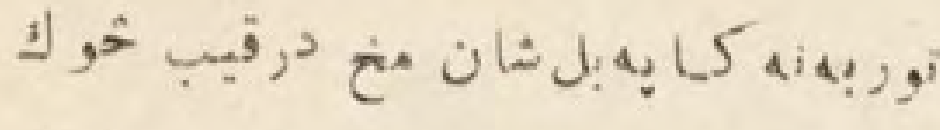

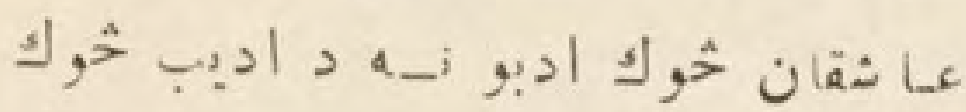

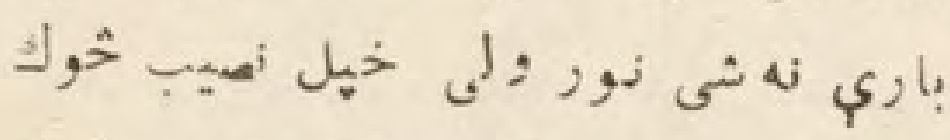

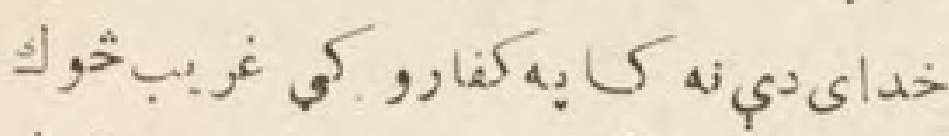

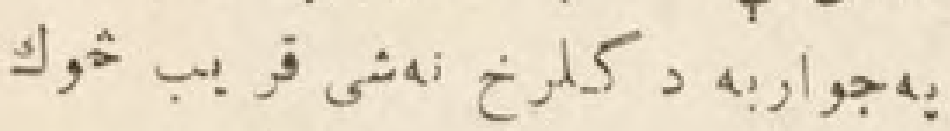

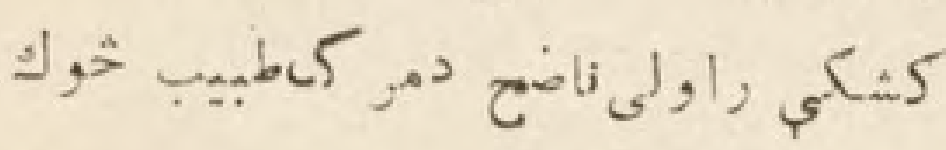

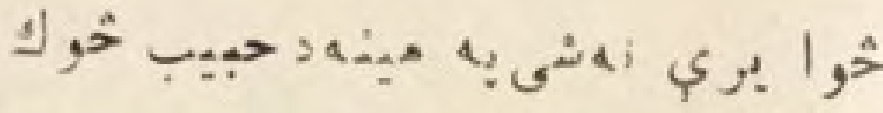

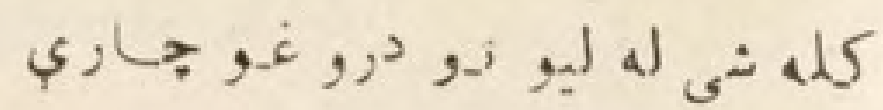

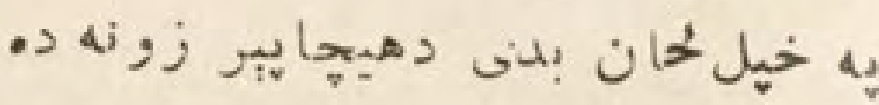
?

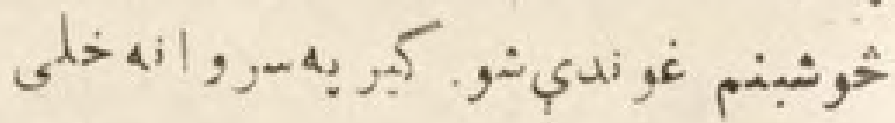

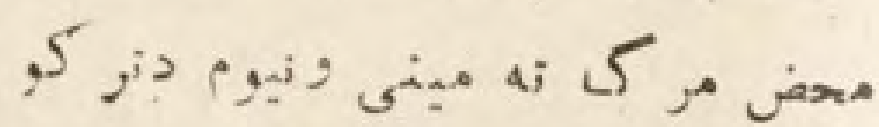

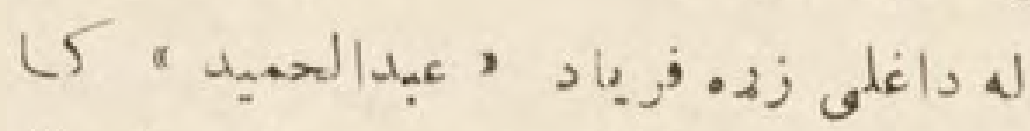

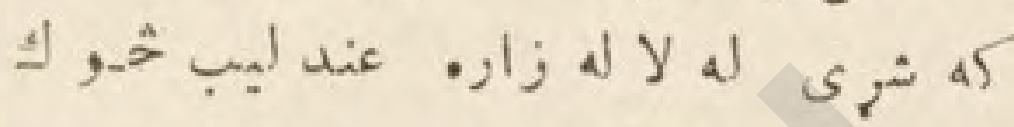

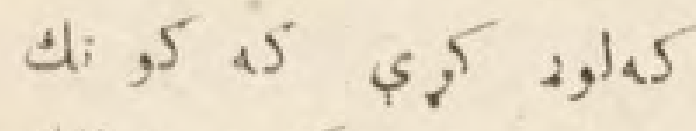

ف

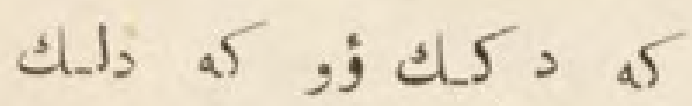

-

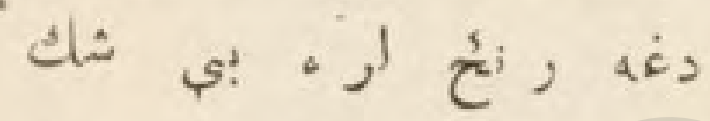

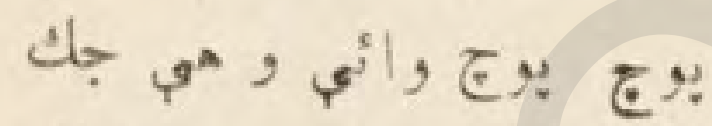
ك.

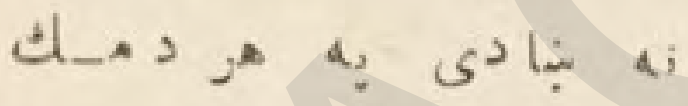

Sأ 5

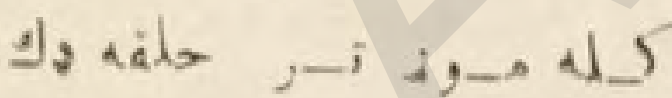

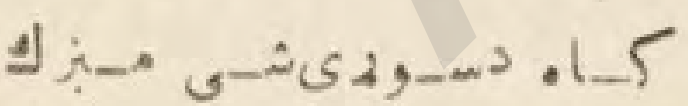
ك

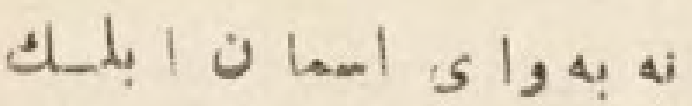

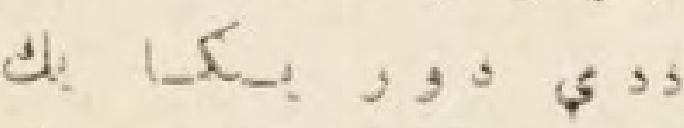

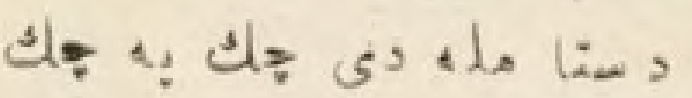

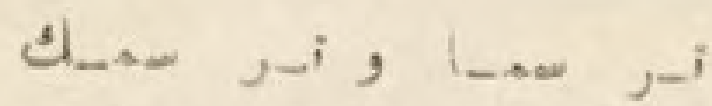

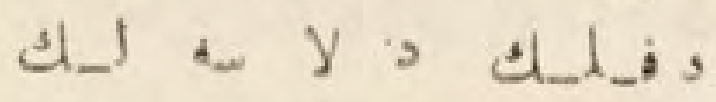
ك)

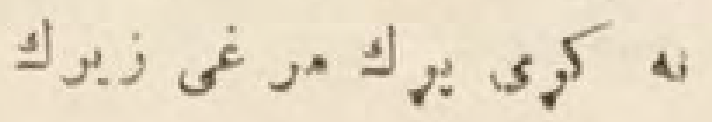

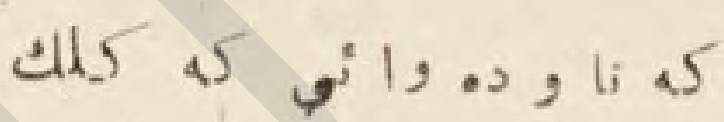

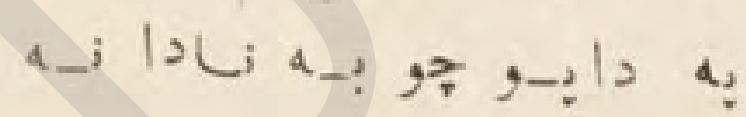

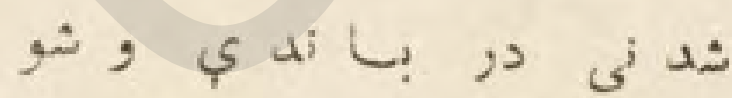

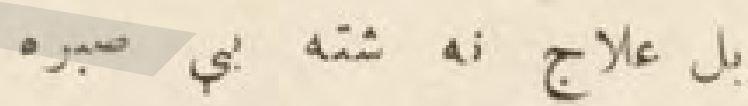

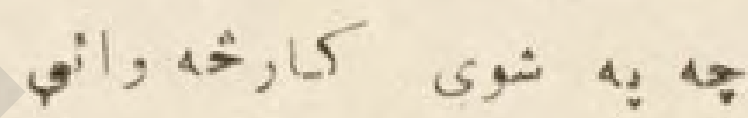

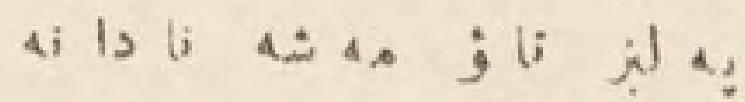

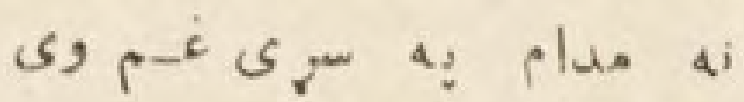

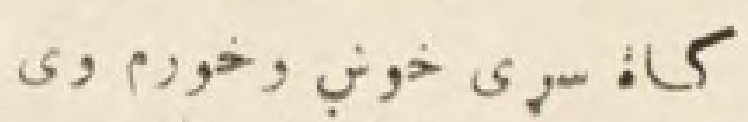

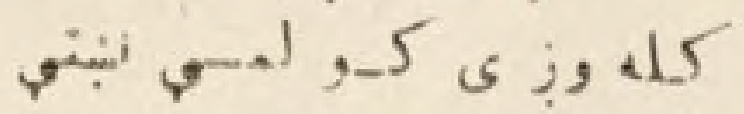

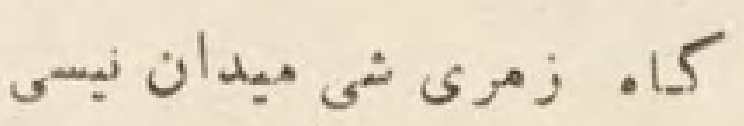

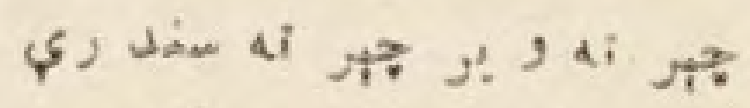

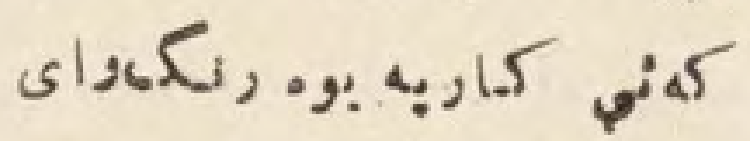

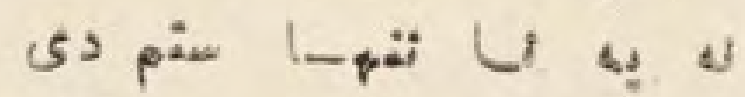
بها .

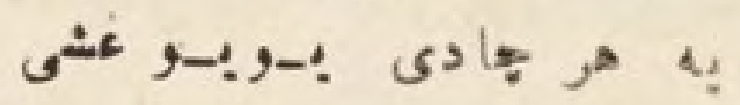

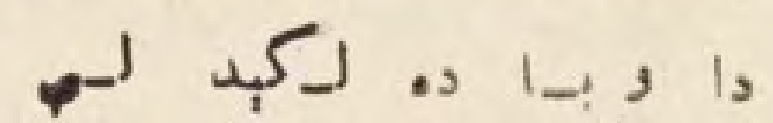

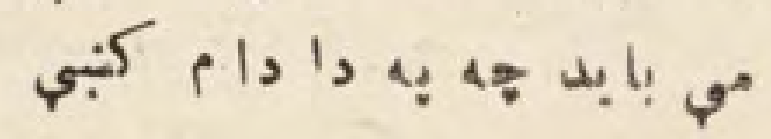

$$
\begin{aligned}
& \text { دمبد صبر سر ور مُو }
\end{aligned}
$$

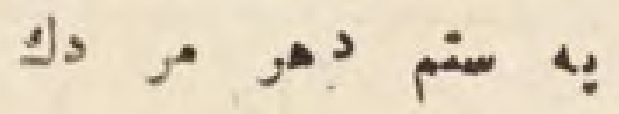


$(z:)$

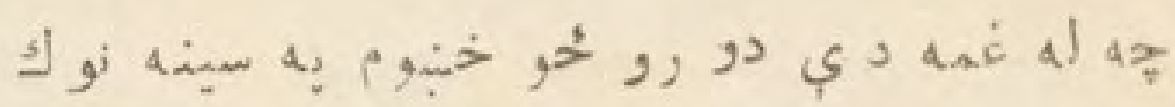

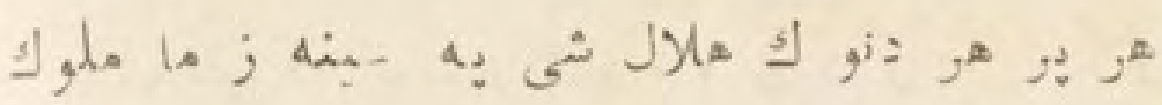

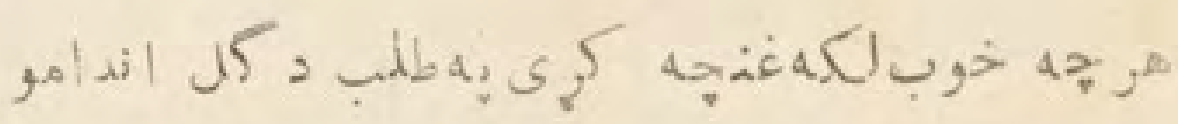

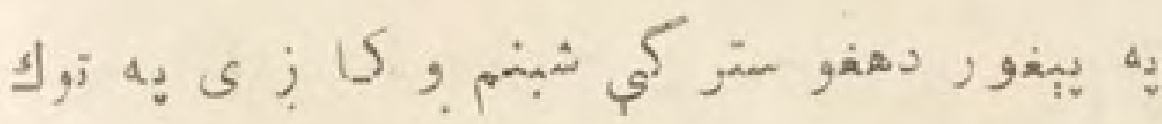

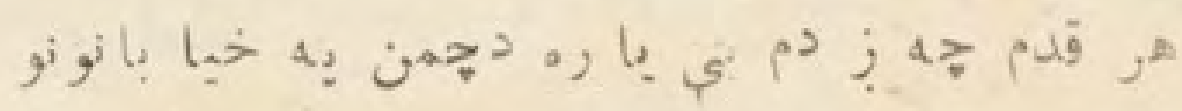

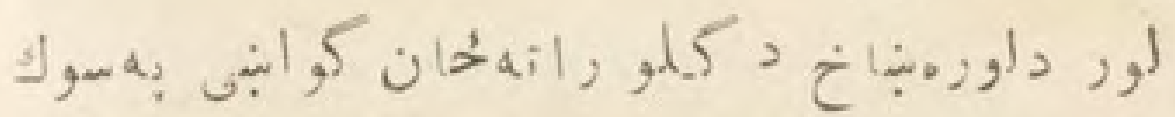

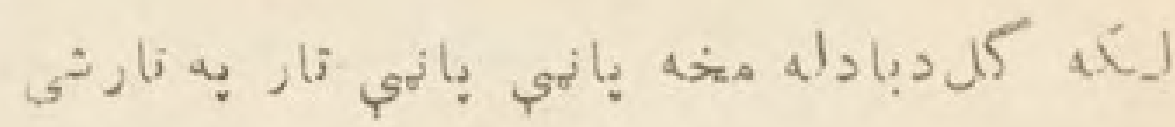

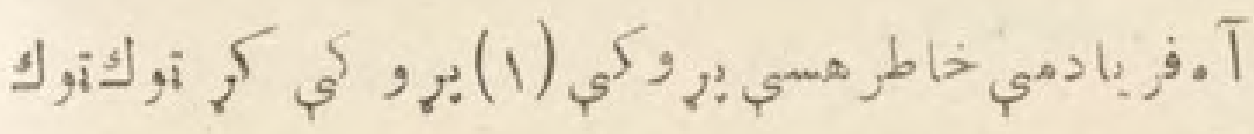

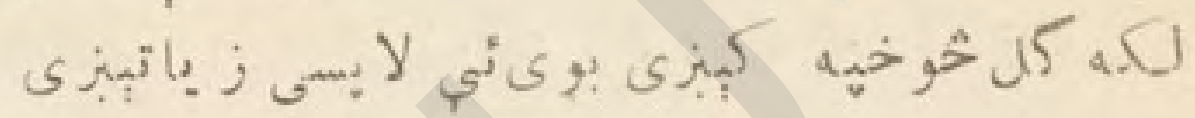

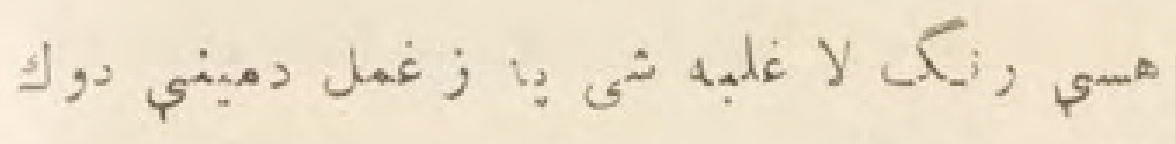

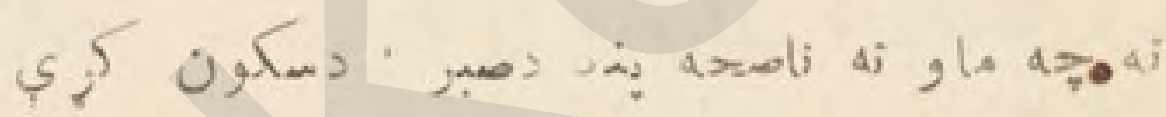

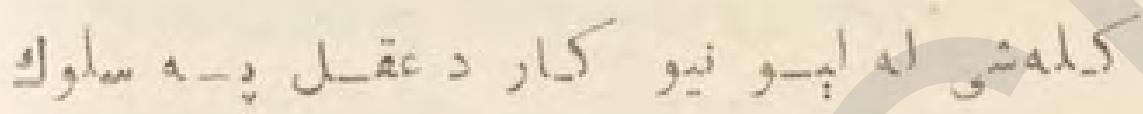

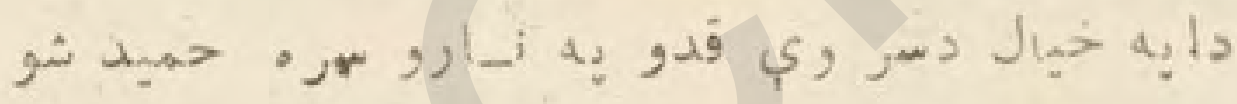

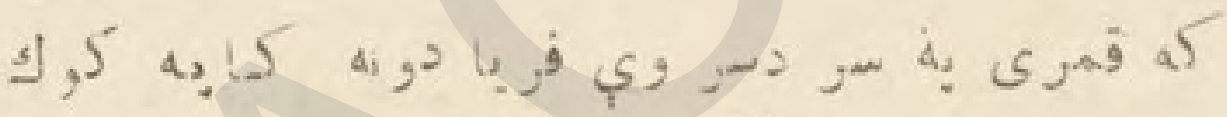

(5

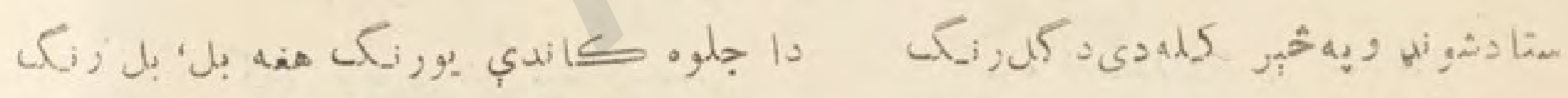

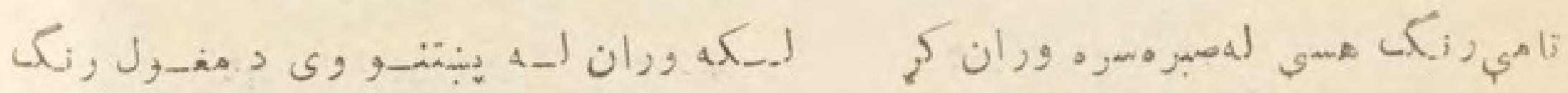

(

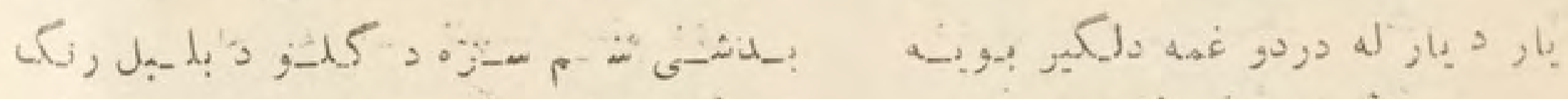

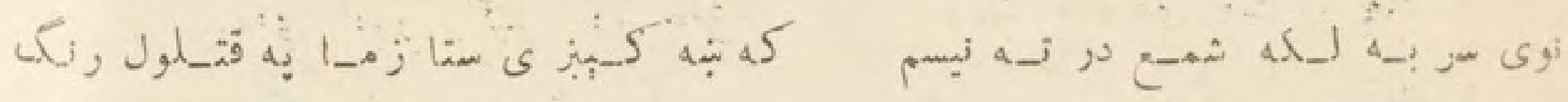

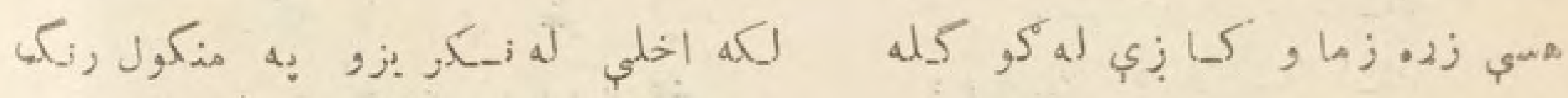

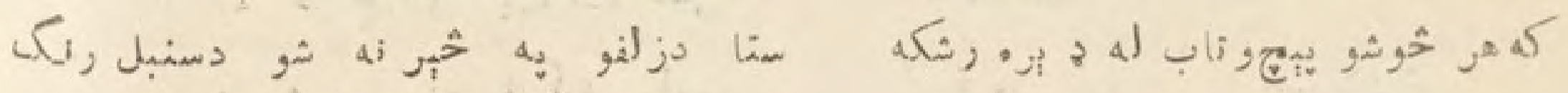

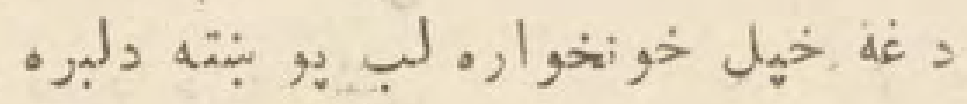

حن

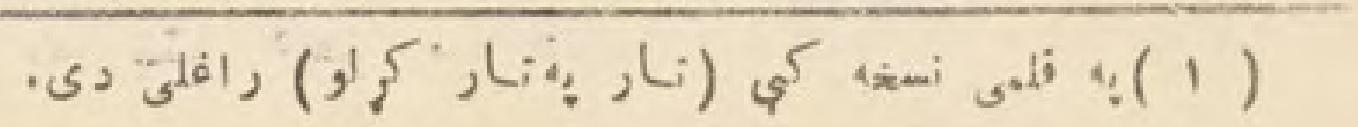




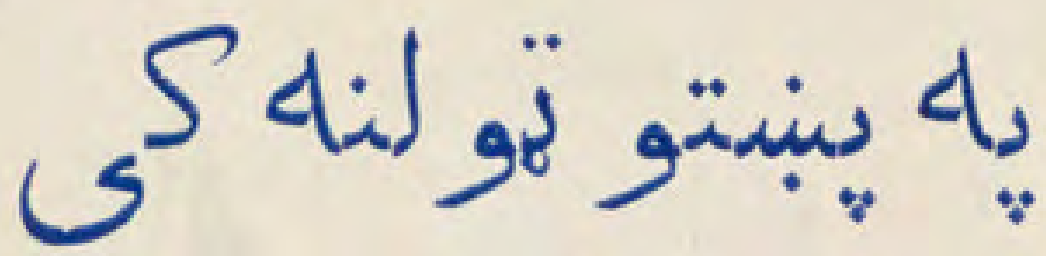

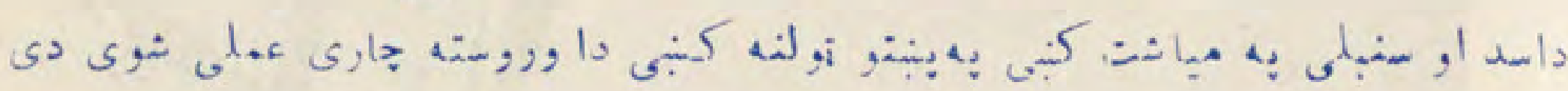

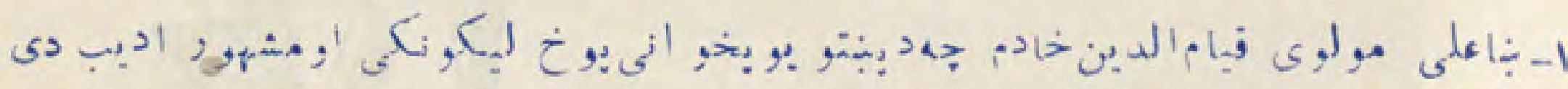

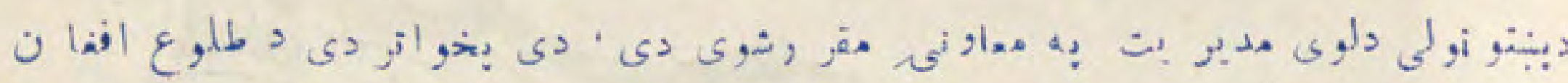

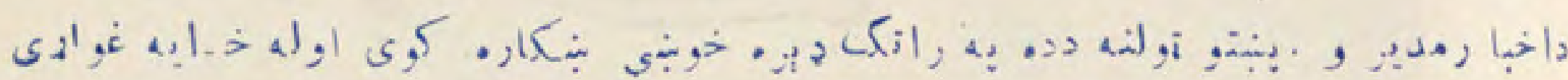

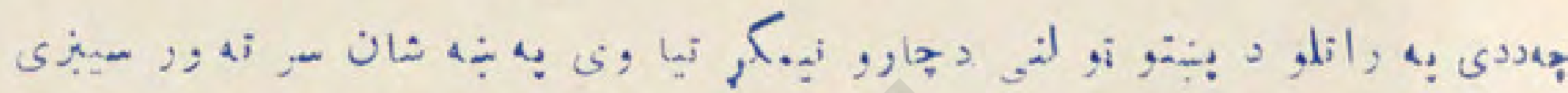

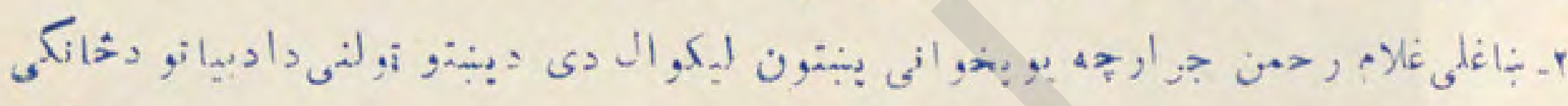

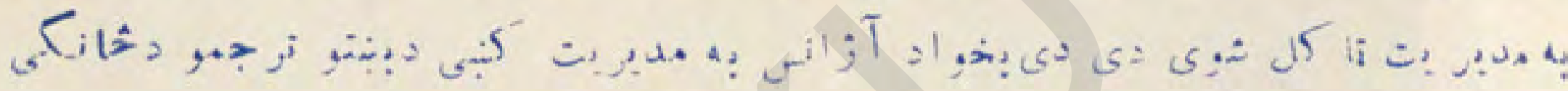

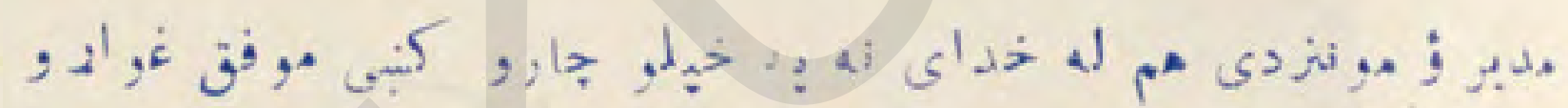

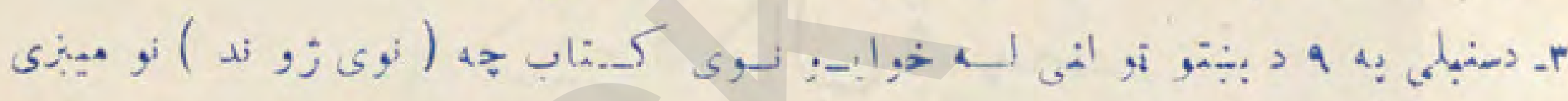

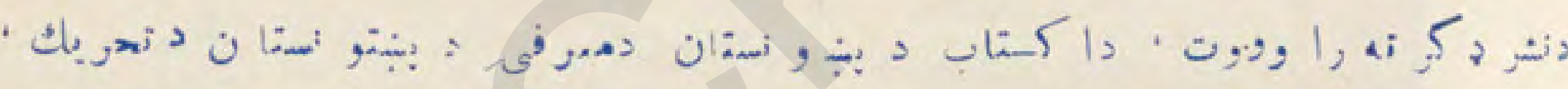

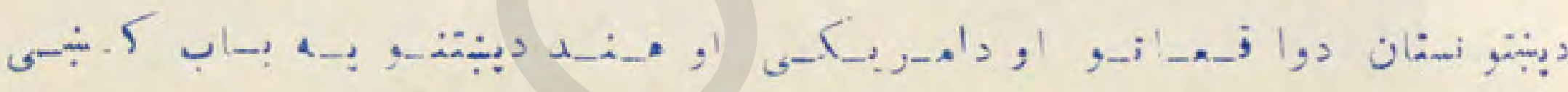

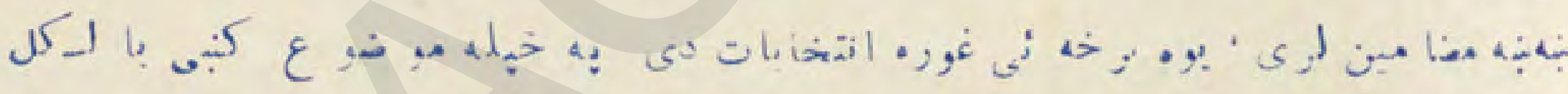

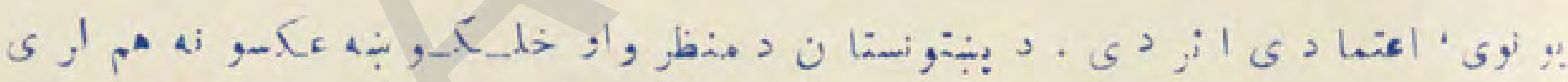

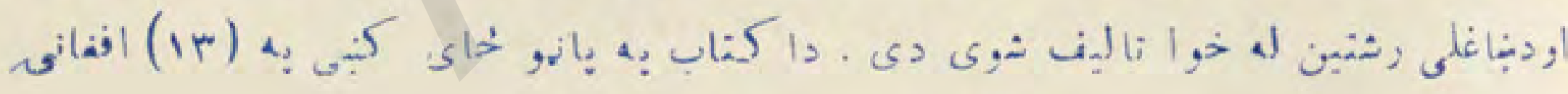

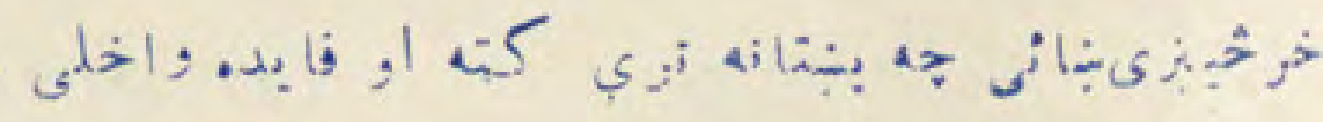

$$
\begin{aligned}
& \text { 察 * } \\
& \text { > انيس فوقالعاده }
\end{aligned}
$$

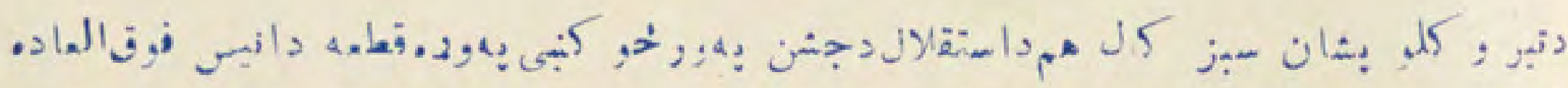

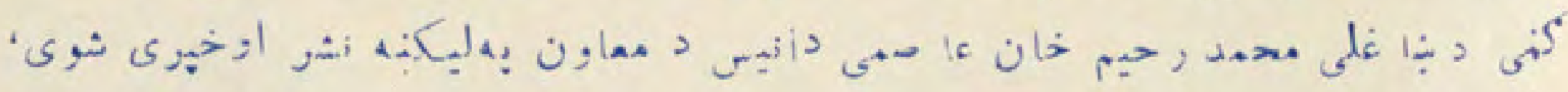

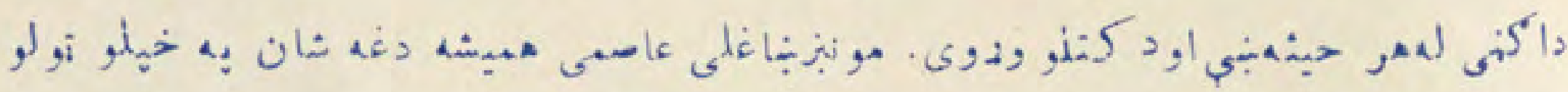

$$
\begin{aligned}
& (., 21) \\
& \text { جارو كبن مونق غرائو . . }
\end{aligned}
$$



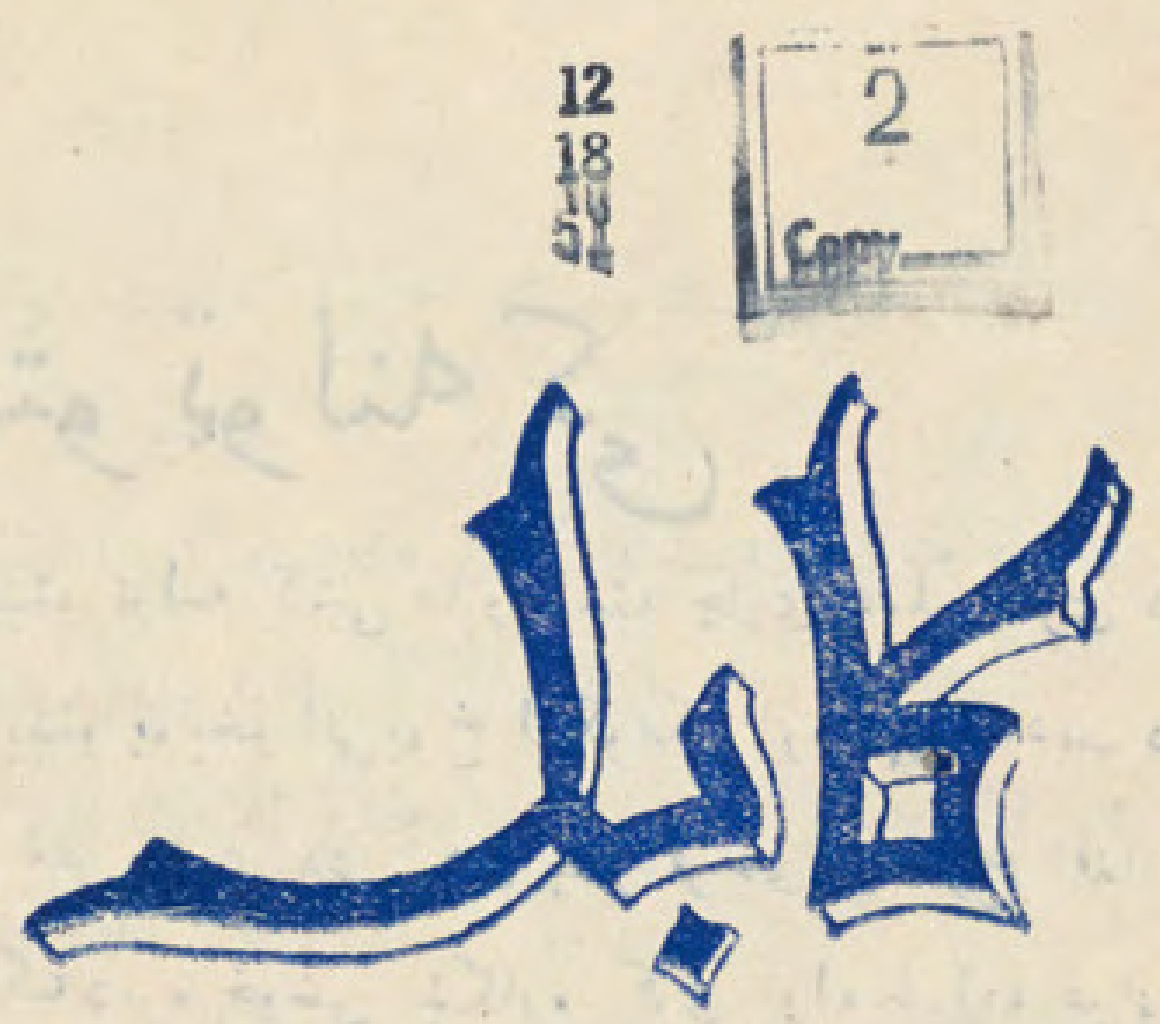

لهيو كال قيهت

ज

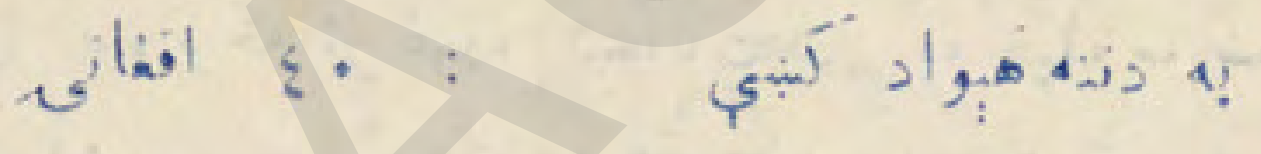

$0,11>\quad \leq \quad$ a

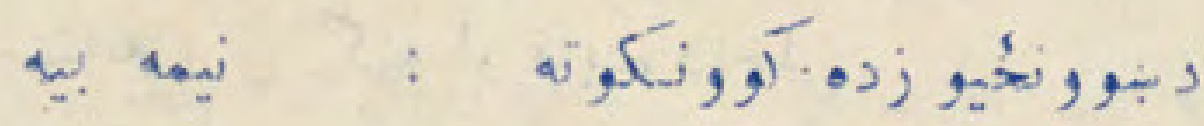

(rqv) 